\title{
IMISCOE
}

RESEARCH

\section{Illegal Migration and Gender}

in a Global and Historical

\section{Perspective}

MARLOU SCHROVER, JOANNE VAN DER LEUN, LEO LUCASSEN \& CHRIS QUISPEL (EDS.)

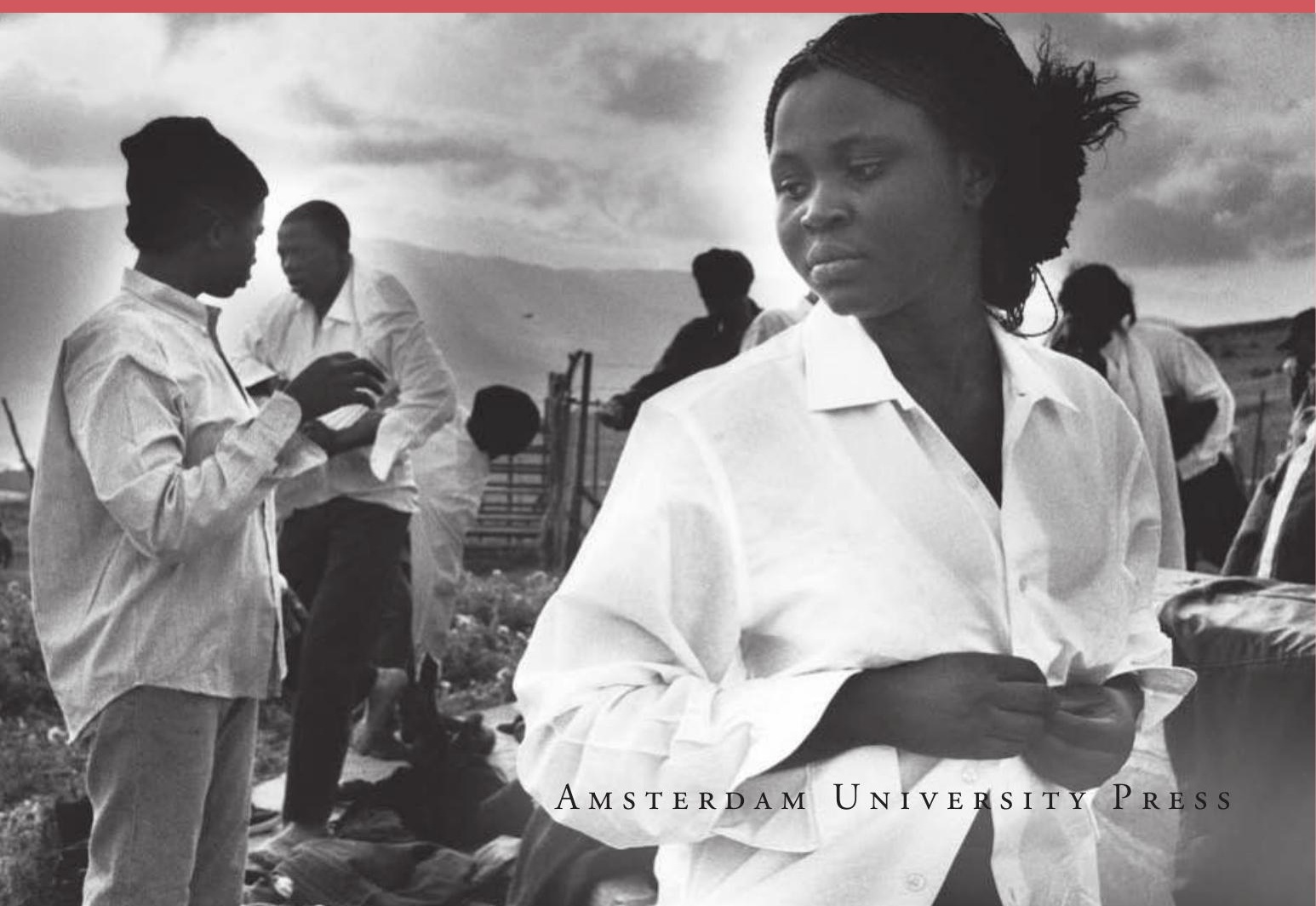


Illegal Migration and Gender in a Global and Historical Perspective 


\section{IMISCOE (International Migration, Integration and Social Cohesion)}

IMISCOE is a Network of Excellence uniting over 500 researchers from various institutes that specialise in migration studies across Europe. Networks of Excellence are cooperative research ventures that were created by the European Commission to help overcome the fragmentation of international studies. They amass a crucial source of knowledge and expertise to help inform European leadership today.

Since its foundation in 2004, IMISCOE has advanced an integrated, multidisciplinary and globally comparative research programme to address the themes specified in its name, short for: International Migration, Integration and Social Cohesion in Europe. IMISCOE members come from all branches of the economic and social sciences, the humanities and law. The Network draws from existing studies and advances innovative lines of inquiry key to European policymaking and governance. Priority is placed on developing a theoretical design to promote new research and offer practical alternatives for sound policy.

The IMISCOE-Amsterdam University Press Series was created to make the Network's findings and results available to researchers, policymakers, the media and the public at large. High-quality manuscripts authored by IMISCOE members and cooperating partners are published in one of four distinct series.

Research

Reports

Dissertations

Textbooks

The RESEARCH series presents empirical and theoretical scholarship addressing issues of international migration, integration and social cohesion in Europe. Authored by experts in the field, the works provide a rich reference source for researchers and other concerned parties.

The REPORTS series responds to needs for knowledge within IMISCOE's mandated fields of migration research. Compiled by leading specialists, the works disseminate succinct and timely information for European policymakers, practitioners and other stakeholders.

The DISSERTATIONS series showcases select PhD monographs written by IMISCOE doctoral candidates. The works span an array of fields within studies of international migration, integration and social cohesion in Europe.

The TEXTBOOKS series produces manuals, handbooks and other didactic tools developed by specialists in migration studies. The works are used within the IMISCOE training programme and for educational purposes by academic institutes worldwide.

IMISCOE Policy Briefs and more information on the Network can be found at www.imiscoe.org. 


\section{Illegal Migration and Gender in a Global and Historical Perspective}

edited by Marlou Schrover, Joanne van der Leun, Leo Lucassen and Chris Quispel

IMISCOE Research

Amsterdam University Press 
Cover photo: @ Ad van Denderen

Cover design: Studio Jan de Boer BNO, Amsterdam Layout: The DocWorkers, Almere

ISBN 9789089640475

e-ISBN 9789048506323

NUR $\quad 74 \mathrm{I} / 763$

(c) Marlou Schrover, Joanne van der Leun, Leo Lucassen and Chris Quispel / Amsterdam University Press, Amsterdam 2008

All rights reserved. Without limiting the rights under copyright reserved above, no part of this book may be reproduced, stored in or introduced into a retrieval system, or transmitted, in any form or by any means (electronic, mechanical, photocopying, recording or otherwise) without the written permission of both the copyright owner and the authors of the book. 


\section{Table of contents}

I Introduction: Illegal migration and gender in a global and historical perspective

Marlou Schrover, Joanne van der Leun, Leo Lucassen and

Chris Quispel

I.I Literature on migrant illegality 9

$\begin{array}{ll}\text { I.2 Illegality from a historical perspective } & 12\end{array}$

I.3 Illegality from a global perspective 20

$\begin{array}{ll}\text { I.4 Regional differences } & 24\end{array}$

$\begin{array}{ll}\text { I.5 Conclusion } & 28\end{array}$

2 Tracing back 'illegal aliens' in the Netherlands, 1850-1940 39

Corrie van Eijl

2.I Entry regulations in the Netherlands 43

2.2 Not illegal but unwanted: Deportations after $1850 \quad 45$

2.3 Jewish refugees: The first 'illegal' aliens 49

2.4 Conclusion 51

3 Policing foreign men and women: Gendered patterns of expulsion and migration control in Germany, 1880-1914 Christiane Reinecke

3.I Forcing out the undesired: Expelling migrant men and women from the German Reich

3.2 Poles, Jews and Prussian wives: Migration control and the expulsions from Prussia

3.3 Dearest Emperor - Dearest Empress: Different patterns of protest

3.4 Conclusion

4 Gendered borders: The case of 'illegal' migration from Iraq, the Horn of Africa and the former Soviet Union to the Netherlands

Ilse van Liempt

4.I Smuggling/trafficking $\quad 84$

4.2 Methodology 86

4.3 Gendered aspects of 'illegal' migration 89

4.3.I Step-by-step smuggling from Iraq 89

$\begin{array}{lll}4.3 .2 & \text { Layla } & 90\end{array}$

4.3.3 Women travelling on their own from the Horn of Africa 
4.3.4 'Tourists' from the former Soviet Union

4.3.5 'Mail-order brides' from the former Soviet Union 98

$\begin{array}{ll}\text { 4.3.6 Tamara } & 98\end{array}$

4.4 Conclusion

100

$5 \quad$ Old and new labour migration to Malaysia: From colonial times to the present

Blanca Garcés-Mascareñas

5.I Exporting goods, importing labour 107

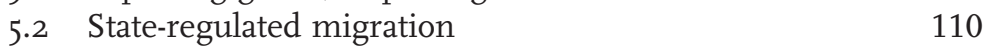

5.2.I Labour circulation $\quad 110$

5.2.2 Labour immobility 112

5.2.3 Powerless position 113

5.3 Managing the labour migrant system 114

5.4 Beyond state-regulated migration $\quad 116$

5.5 Meanings of non-regulation 119

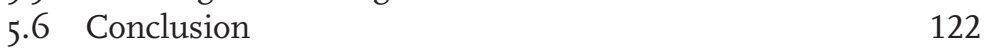

6 The romantic appeal of illegal migration: Gender, masculinity $\begin{array}{ll}\text { and human smuggling from Pakistan } & 127\end{array}$

Ali Nobil Ahmad

6.I Theoretical framework 128

$\begin{array}{ll}6.2 \text { Methodology } & 130\end{array}$

6.3 Who makes the decision to migrate? 133

6.4 The romantic appeal of illegal migration 137

6.5 Sexuality and youth cultures in communities of men 141

6.6 Conclusion 146

$7 \quad$ Migrant domestic workers in the Middle East 151

Annelies Moors and Marina de Regt

7.I The feminisation of migration to the Middle East 152

7.2 Legal versus illegal migration? 153

7.3 The gendering of women's paid domestic work 154

7.4 Leaving the country of origin: Intentions, debates $\begin{array}{ll}\text { and policies } & 155\end{array}$

7.5 Travelling and entering the country of destination 157

7.5.I Agencies 157

7.5.2 Friends and relatives 159

7.6 Employment and residency: Rights and duties 160

7.7 A trend towards freelancing 162

7.8 Leaving and going 'back home' 164

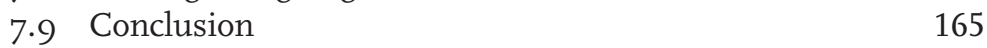


8 Illegal migration, gender and health care: Perspectives from Germany and the United States

Heide Castañeda

8.I Comparing illegal migration in Germany and the US 173

8.2 Gender, reproduction and the nation 176

8.3 Access to medical treatment: Policy situation 177

8.4 Pregnant and illegal 180

8.4.I Gendered border crossings 180

8.4.2 Pregnant and seeking medical care 181

8.4.3 Protection from deportation 182

$\begin{array}{ll}8.5 \text { Conclusion } & 185\end{array}$

$\begin{array}{ll}\text { About the authors } & 189\end{array}$ 



\title{
1 Introduction: Illegal migration and gender in a global and historical perspective
}

\author{
Marlou Schrover, Joanne van der Leun, \\ Leo Lucassen and Chris Quispel
}

The differences between men and women involved in migration have been studied from various angles in the last decades (Sinke 2006). However, study of the 'illegal' side of migration has remained relatively sparse. A special issue of International Migration Review on gender and migration offers an impressive overview of what has been written on gender differences in migration in recent years (Donato, Gabaccia, Holdaway, Manalansan \& Pessar 2006), but the focus has mainly been on legal migration. Not much light is shed on the historical roots and global differences within illegal migration. In this book we therefore use a historical and global perspective to look at illegality - one of the leading subjects of current debates on migration - and the way the construction of illegality can help us understand migration from a gender perspective. Since the construction of migrant illegality is related to the construction of citizenship, research into the construction of migrant illegality clarifies how citizenship is defined and how mechanisms of inclusion and exclusion work out differently for men and women.

Much of the literature on migrant illegality is recent, has little eye for historical developments, focuses on the United States and is predominantly concerned with policy aspects (De Genova 2002; Van der Leun 2003). This book looks at changes in the construction of migrant illegality from an interdisciplinary, socio-legal and historical perspective. The chapters of our book cover a long period of time - the nineteenth and twentieth centuries - and a large geographical area (Germany, the Netherlands, Britain, the US, Mexico, Malaysia, the Middle East, Iraq, the Horn of Africa, the Soviet Union and Pakistan). Our leading question is: how has illegality been constructed over time and space and to what extent was this different for men and women?

\subsection{Literature on migrant illegality}

Several authors have strongly criticised the use of the term 'illegal migrants' (for a summary see Koser 2005). Migrants can never be illegal themselves, only their activities can be regarded as such. Because of 
the association of illegality with crime, authors have suggested replacing the term 'illegal' with 'undocumented', 'unauthorised' or 'irregular. However, these alternative terms are as problematic as the term 'illegal'. 'Undocumented' is ambiguous, since sometimes it is used to denote migrants who have not been documented and sometimes to describe migrants without documents. Neither situation applies to all illegal migrants. Furthermore, undocumented migrants who apply for asylum are not illegal. Similarly, not all illegal migrants are necessarily unauthorised, and so this term, too, is often incorrect. The term 'irregular' is problematic since it is not clear to which rules or regulations it refers. Furthermore, the term 'irregular migration' leads to confusion, because it is also used to describe migration that takes place at irregular time intervals, as opposed to regular (seasonal) migration. The term can also be understood to mean disorderly, which again has a criminal association. Replacing the term 'illegal' because of its negative connotation does not help, since any new term will acquire a similar connotation in the light of how the topic is generally discussed. We therefore choose to use the term 'illegal' despite its disadvantages (cf. Ngai 2004). It has the advantage that it refers to the way in which migrants relate to the construction of what is legal (Samers 200I: 142).

The illegal exit, entry and residence of migrants are often associated with other illegal activities (Jandl 2007). The underlying assumption is that one illegal activity will lead to another. In our view, the construction of what is legal and illegal in migration should be restricted to exit, entry and residence. Work should only be included when permission to work, and the permission to leave, enter or stay are interconnected.

Currently, Western states define illegal migration as: I. crossing borders (leaving or entering a country) without the consent of authorities; 2. crossing a border in a seemingly legal way though using false documents or using legal documents in a false way, or by making use of bogus marriages or impostor relatives; 3 . staying in a country after the expiration of legal status (cf. Heckmann 2004: IIO6). In reality, however, the meaning of illegality shifts across time and space, as we will show. It is a fluid construction and is the result of increased state control over mobility.

The construction of illegality is related to the idea that control over its territory is a task of the state (Abraham \& Van Schendel 2005). A distinction can be made between what states consider to be legitimate ('legal') and what people consider to be legitimate ('licit'). Many transborder movements of people are illegal because they defy authority, but they are quite acceptable, 'licit', in the eyes of participants. The state controls who occupies, uses or crosses its territory. Individuals who systematically contest or bypass state controls are not simply flouting the 
letter of the law. They are also bringing into discussion the legitimacy of the state by questioning its ability to control its territory. For reasons of scale and logistics, not all states have the ability to control their people and territory, and this is perceived as a threat by other countries (Abraham \& Van Schendel 2005).

Illegality has been addressed from a gender perspective before, but mainly from a very specific angle: past literature focuses on the trafficking of women (Phizacklea I998). It is as trafficked women that illegal women migrants gain a high visibility in academic, public and political discourse. In these discourses, trafficking is used as a synonym for prostitution (Agustin 2005: I08). Men are often spoken of as being smuggled and women as being trafficked. The definition of trafficking emphasises that people are transferred against their will, while the definition of smuggling stresses illegal entry to which the migrant agrees and for which he usually pays (Koser 2005: 7). In the distinction between trafficking and smuggling, men are depicted as in control while women are portrayed as dependent and docile victims.

The assumption that women are trafficked has resulted in stronger monitoring of migrant women, as opposed to men (Erel 2003). It has also led to the generalisation that all migrant women are portrayed as being at risk of rape and other sexual harassment (Okin 1999). The narrative of victimhood and the assumption that women are forced to migrate and work in prostitution has brought about protective measures, which sometimes help women but also restrict their choices. There are countries today - like Bangladesh, Indonesia, Myanmar (Burma) and Nepal - that have banned or restricted the emigration of women in an attempt to protect them (International seminar 2004; Siddiqui 2003; Moors \& De Regt in this volume). In recent years, the discourse on prostitution and trafficking has dominated conferences on women's rights, and this usually leads to more restrictions for women (Soderlund 2005: 65). Since women are cast as victims, these restrictions on their rights are justified by claiming to protect them.

Several authors have tried to explain why there is such an emphasis on trafficking and prostitution when it comes to women and illegal migration. Chapkis (2003) has shown how this discourse combines female powerlessness and childlike sexual vulnerability. A distinction is made between 'violated innocents' and 'illegal immigrants' that is based on sex and gender. Trafficked victims are described as vulnerable women and children who were forced from the safety of their homes into gross sexual exploitation. They are distinguished from economic migrants - male - who have wilfully violated national borders for individual gain. The state offers protection to the former and punishment to the latter. It relies on moral panic about 'sexual slavery' supported by 'slippery statistics and sliding definitions'. The protection that is of- 
fered to the 'innocent' helps reinforce the suggestion that the punishment meted out to the 'guilty' is justified (Chapkis 2003: 924).

Berman (2003) has shown how the European trafficking discourse is related to globalisation, the end of the Cold War and the expansion of the European Union. Governments currently feel they are losing control of borders and issues of migration. The current sex-trafficking discourse, involving innocent victims, violated borders and criminality, can be seen as a means of problematising immigration and justifying anti-immigration policies (Berman 2003: 57). The discourse tends to focus on the 'white-ness' of the 'victims'. All migrant Eastern European sex workers are portrayed as a group of innocents who need the protection of the state. The discourse shows great similarities to the White Slavery Scare of around I900, with its emphasis on youth, innocence, 'whiteness', corruption and foreignness (Doezema 2005). While Eastern European women are portrayed as victims, Eastern European men are associated with crime.

Immigrant women are not only restricted by this victimhood discourse. Women who work in prostitution may also benefit from this situation if they emphasise suffering and stress that they are victims who are doing this work temporarily in order to support their children or siblings (Brennan 2004). This approach increases their incomes and their opportunities, including that of being 'rescued' from prostitution and being offered subsequent migration to the rescuer's country of residence through marriage.

There are thus two rather separate literatures on illegality. Firstly, there are studies that deal with the construction of illegality in connection with the role of the state. Secondly, there are numerous publications on women and illegality that almost exclusively discuss prostitution and trafficking. In this book we combine these two literatures, but we shift the focus from the trafficking discourse to other, underexplored differences between men and women in illegal migration.

\subsection{Illegality from a historical perspective}

The construction of illegality has changed considerably over time. The chapters in this volume deal with the nineteenth and twentieth centuries, but the roots of the construction of illegality can be traced back to earlier centuries. Although the term 'illegal' dates from the I930s (see Van Eijl in this volume), the concept of being illegal is much older. It is closely linked to the process of state formation and systems of local poor relief (Feldman 2003a). In the following we will give a brief overview of some key developments in the relationship between state formation, mobility control and exclusion since the Early Modern period. 
We will demonstrate that illegality is not as 'new' as many scholars assume, and that current manifestations of gendered illegality can be better understood when placed a historical perspective.

For centuries, authorities have formulated rules on the exit, entry and residence of subjects and aliens (Torpey 2000; Caplan \& Torpey 200I; Hoerder 2002; Moch 2003; Higgs 2004). Mobile groups are of interest to states when they move between politically significant territorial units (Abraham \& Van Schendel 2005). The strengthening of national states in the nineteenth century made the crossing of national borders more important than that of other territorial boundaries. Before the nineteenth century the central state was weak and not very active in formulating rules on exit, entry and residence. States only formulated rules regarding the small number of people who wanted to be naturalised (Sahlins 2004). Any discussion of illegality pertained to the crossing of municipal and not the national boundaries (Fahrmeir 2007).

In large parts of Europe, including the United Kingdom, citizenship was defined locally, and the rules on in- and exclusion were developed at the municipal level. Crucial for the decision to admit 'aliens', defined as migrants coming from another municipality, was whether they were believed to be able to earn their own money and not burden the local poor relief funds. When the local economy slumped, alien policies became restrictive, especially towards poor migrants. Migrants who had been admitted but not granted local residency could be sent back to the municipality that was responsible for their poor relief, often their birthplace. This principle formed the basis of the English Poor Laws and the German and Austrian Heimatrecht (Lucassen I996; Lees I998; Gosewinkel 200I; Komlosy 2003; Feldman 2003a), though was also applied in the Netherlands (Van Leeuwen I992). Differences were made between migrant men and women within the system of poor relief. All poor migrants had to prove that they were deserving, but women more often than men had to also show that they lived up to a certain moral standard (Van de Pol \& Kuijpers 2005).

The 'foreign' poor were deported regularly, but that did not always mean their residence was illegal. They were not deported because they did not have permission to enter a country or stay there, but because they could no longer support themselves. Illegality may lead to deportation, though not all deportations resulted from illegality (see Van Eijl in this volume).

In the Early Modern period authorities tried to restrict the movement of people who were not tied to the highly organised labour market and who could avoid taxation and regulation (Lucassen I997; Eltis 2002). Vagrants were accused of avoiding regular employment and using itinerant occupations as a cover for begging and theft. It is inter- 
esting that some of these vagrants, like illegal immigrants today, moved in and out of illegality, depending on their ability to find work. These European vagrant policies were reproduced in the colonial empires of the nineteenth century. People who refused to follow the highly repressive rules of the labour market were branded as vagrants (Singha 1998). When they were put to work in other parts of the empire, breaching contracts or scalloping could render them illegal (Mohapatra 2007; see also Garcés-Mascareñas' chapter in this volume).

The regime of the Early Modern period could lead to various forms of 'illegality'. Poor migrants could circumvent local restrictions and settle in a town without permission until they were caught and deported. Migrants who had been admitted but who had not yet gained local citizenship (often granted only after ten years of residence) refrained from applying for poor relief since this could lead to expulsion. They kept a low profile and accepted low wages and bad working conditions (Komlosy 2004). Although their presence was not illegal, their situation has much in common with the situation current illegal immigrants find themselves in. In the eighteenth century, when the economic situation deteriorated in large parts of Europe, the 'hunt' for 'illegals' intensified. When poor migrants had trouble proving their identity, it was not clear who should be held responsible for their support. For 'gypsies' and 'vagabonds' this led to extreme measures in Germany, the Netherlands, France and the UK. Their illegal presence was punished by banishment or death (Fraser I992; Lucassen, Willems $\&$ Cottaar 1998).

In the Early Modern period there were few restrictions on immigration at the state level. Many states welcomed large groups of immigrants, often for religious and political reasons. This was the case with the Huguenots from France after 1685 in Geneva, Brandenburg and the Dutch Republic, Protestants from Salzburg around 1730 in England and foreign revolutionaries in France after 1789, to mention a few examples (Bade, Emmer, Lucassen \& Oltmer 2007). Furthermore, from a mercantilist perspective people were considered an asset. Some states, like Russia and the German states, tried to lure migrants to their territory. For the same mercantilist reasons, emigration was often regarded as undesirable. Until the middle of the nineteenth century, many states, especially in Central Europe, forbade people to emigrate without permission (Torpey 2000; Green \& Weil 2007). States viewed emigration as a loss of money (taxes) and men (soldiers), or feared that they would become responsible for those who were left behind (women and children). Restrictions on movement were clearly gendered. France and Germany, for instance, prohibited and restricted the permanent emigration of men who had not fulfilled their military duty (Torpey 2000; Moch 2003), while some German states forbade the temporary 
migration of women who intended to leave their children behind (Schrover 200I).

In the nineteenth century local autonomy broke down and was transferred to the central state level. Local authorities remained responsible for poor relief but lost the right to refuse internal migrants who were likely to become a public charge (Komlosy 2004). With the spread of industrialisation and the rapid growth of cities, central states increasingly switched from a mercantilist to a liberal policy and stimulated the free mobility of their citizens and foreigners (Torpey 2000; Fahrmeir 2000). Some of the restrictive and immobilising local poor relief legislation was abolished, creating a de facto national labour market and allowing workers to settle in centres of industrial activity like Lancashire and the Ruhr area (Lucassen 2005).

In the middle of the nineteenth century the redefinition of aliens in national terms coincided with an international relaxation of migration controls, at least in the Atlantic region (Noiriel I99I; Fahrmeir 2000; Caplan \& Torpey 200I; Hoerder 2002). In this first phase of globalisation, passports were abolished and exit restrictions lifted, resulting in a spectacular increase in the volume of international migration (Williamson \& O'Rourke 2002). As long as liberal night watchman states did not provide welfare or other social goods and services to their citizens, states welcomed cheap labour in the hope that this would boost the economy (Fahrmeir, Faron \& Weil 2003). This made the period between I850 and I9I4 the heyday of free migration, with some 50 million international migrants travelling across the Atlantic and an equal number moving within Europe (Moch 2003).

In Asia there were similar developments, with large numbers of migrants flocking to centres of capital in Northern and South-East Asia (McKeown 2004; Manning 2005; Lucassen 2007). At the same time, however, Asian migrants were excluded as much as possible from the Atlantic world and white settler colonies, creating a global, racially motivated migration regime which aimed at keeping Asians in Asia, except for relatively small numbers of indentured migrant workers, mostly in the Caribbean.

The exclusion of people who were seen as racially inferior produced forms of illegality. Chinese men who migrated to California and Australia at the time of the Gold Rush in the I850s were resented by white workers and after much pressure were excluded from the territory and the labour market altogether. The American Chinese Exclusion Act of I882 - in effect until I943 - forbade the immigration of Chinese, except for those who were 'honest' merchants and businessmen (Chan I99I; Gabaccia I997; McKeown 200I; Zolberg 2006). Chinese men who were found to have entered under false pretexts or with forged papers were declared illegal and were deported (Wong \& 
Tong 2005). The Chinese Exclusion Act did not mention women, since it was assumed that all Chinese women who attempted to enter the US were prostitutes and the 1875 Page Law barred prostitutes from the US (Calavita 2006). Racial arguments also influenced the restrictionist US quota acts of the early I920s (Zeidel 2004).

Within Europe, cultural and racial notions of inferiority also influenced state practices. At the end of the nineteenth century states became more sensitive to demands for the restriction and exclusion of foreign migrants by various political pressure groups, such as unions and nativist movements. This is illustrated by the regulation of Polish-speaking Russian agricultural workers in the Prussian countryside from the I89os onwards. These workers, both men and women, were admitted temporarily and could only work in Prussia's agricultural sector. Russian Poles had to leave Prussia on 20 December and could only return on I February of the next year (the so-called Karenzzeit). This rotation system was meant to discourage migrants from settling permanently. Dodging the rotation system and shifting to other economic sectors was forbidden and resulted in a form of illegality. An elaborate monitoring system was developed, which gradually extended its reach to all foreign workers in Prussia. These migrant workers could only evade regulation by migrating to other German states or engaging 'illegally' in occupations outside the agricultural sector (Bade 2000: 222-223).

The Prussian policy foreshadowed a more general development that occurred in Western Europe and the US from I9I4 onwards. The changes after I9I4 were the outcome of developments that had started almost a century earlier. After I9I4 the urge to control became the ability to control. It was part of what Rosenberg calls the bureaucratic fantasy of achieving total control over society (2006: 7). The origin of this desire can be traced back to the beginning of the nineteenth century, when state officials developed sweeping visions of the benefits of technical and scientific progress applied to all fields of human activity as a means of simplifying a messy, 'illegible' world (Scott 1998). The cholera epidemics of the nineteenth century and greater awareness of how contagious diseases spread contributed to this overall perceived need for control (Rosenberg 2006: 24).

Laws that were introduced in the nineteenth century in order to control mobility faded into oblivion soon after having been introduced, as had been the case in the Early Modern period (Fahrmeir 2003). In the nineteenth century governments made no serious effort to enforce laws since they knew they did not have the ability to do so. Laws were thus not introduced in order actually to control mobility, but rather to create an impression of being in control (Schlumbohm I997). The states' successful monopolisation of the legitimate means of movement had to wait for 
the creation of elaborate bureaucracies and technologies, which began to develop at the end of the nineteenth century (Torpey I998: 240).

The urge to register people, however, sprang not only from increased possibilities. A changing conception of nationhood was also important. Before I900, few efforts were made to register people by nationality, and many people did not know what nationality they had (Schrover 2002; Rosenberg 2006: 24). Changed ideas about nationality and belonging, and the failure of states to identify enemy nationals in their midst at times of war, increased the tendency to register people by nationality (Brubaker 1992; Rosenberg 2006: 44). With the rise of nationalism it was considered increasingly important - in terms of national security - for states to be able to identify their citizens. Too many foreigners on a nation's territory made it difficult for the state to identify its populations, to legitimise its government and to maintain its sovereignty (Hollifield i998; Fahrmeir 2007).

In around I900, concepts of nationhood became mixed with racism (Van der Linden I988; Lucassen I998). The aim of the controls was not to limit the number of migrants entering a country, but to minimise the perceived impact of specific peoples on a nation's 'health' and security. Notions of race and nationality did not inevitably lead to exclusions; rather they provided a palette of ideas that influenced both popular and governmental thinking about the place of 'aliens' (Triadafilopoulos 2004). Changing ideas on nationhood led to a different perception of who 'the people' were.

The first decades of the twentieth century saw two contradictory developments. On the one hand, there was an apparent immobility (Langewiesche \& Lenger 1987). In Germany, migration rates had already started to drop before the First World War (Hochstadt I999: 2I7250). Overall, immobility came to be seen as the norm (Cresswell 2006: 26). On the other hand, in the midst of this declining trend in mobility, the First World War and its aftermath were an unprecedented period of flux. The number of people displaced by the war was greater than ever before (Baron \& Gatrell 2003). The war led to a reconfiguration of power and territory and the shifting of territorial borders. People fled from states that ceased to exist. Redefinitions of citizenship and the creation of new states left some people stateless. The number of displaced persons and the sense of displacement were far greater than in any earlier period. Governments felt, and were forced to feel, that they had to deal with this displacement. The urge towards restricting mobility was in part a response to this period of flux within an overall declining trend in mobility.

The increased number of restrictions and controls after the First World War were also the result of a rise in political participation and the extension of social rights (Lucassen I998). Workers urged that the 
labour market be protected from foreign labourers. The extension of voting rights made politicians sensitive to these demands. The preferential treatment of non-migrant workers was only possible, however, if they could be distinguished from foreigners. As a result, workers and their unions started to press for more registration. After the First World War this 'revolution identitaire' (Noiriel I99I) increasingly led to attempts to shield the labour market from foreign labour (Noiriel I99I; Van Eijl 2005; Hahn, Komlosy \& Reiter 2006). More money became available for registrations, which led to more elaborate systems of administration (Rosenberg 2006: 46-49).

After each political crisis in Europe - such as those in I8I2, I848, I866 and 1870 - there was an increase in the attempt to control mobility. The First World War was no different in that respect. A crucial difference, however, was that Russian revolutionaries were more successful than those of 1848 , for instance. As a result, controls that were put into place during and after the First World War slackened only gradually and partially and became more institutionalised.

Furthermore, the arrival in England (Bland 2005) and France (Camiscioli 200I) of immigrants from the colonies in Asia and Africa led to a stronger urge for control. These migrants, all men, had served in the merchant marine during the war, and now claimed their right to stay in the mother country as citizens. Their arrival and claims, and their marriages to white women, were cause for alarm and a reason for an intensification of registration (Rosenberg 2006).

From the I880s onwards, mobility from Europe was affected by US restrictions on migration. The US authorities initially had no intention of restricting the entry of migrants to the country, but they did want to prevent paupers and criminals from coming by introducing controls and barriers at the frontier (Ellis Island in I892) as well as in the countries of departure. This idea of 'remote control' had already been developed earlier but became increasingly important after the First World War (Zolberg 2006). After the First World War in Germany it was private shipping companies rather than the state that played an important role in exercising this remote control (Feldman 2003b; Brinkmann 2008). The shipping companies not only organised the transport by train from the Russian border to German ports, but also carried out tasks that now commonly fall to the state, such as checking passports at the Russian border and denying entry onto German soil. German authorities were not only unwilling but also unable to exercise this control.

The so-called White Slavery Scare, in which European women were believed to be exported to the colonies and elsewhere and forced into prostitution, preceded the US move to increase restrictions on mobility. Novels, pamphlets, newspaper articles and a box office success film 
Traffic in Souls (I9I3) inflamed the White Slavery Scare (Haynes 2004). The protection of 'innocent' foreign women was used to legitimise restrictions on mobility.

In the early twentieth century in the US, the authorities made use of the Likely to Become a Public Charge provision (LPC) to exclude or evict women who were suspected of immoral behaviour (Moloney 2006). The LPC provision functioned in a way similar to that of the poor relief system in the Early Modern period. Although men could also be excluded or deported under the LPC provision, between 1892 and 1920 women were by far the main victims, especially those who travelled alone. They were considered either to be more likely unable to support themselves or to be immoral. Van Eijl's and Reinecke's chapters (in this volume) support the findings of other researchers that the sexual behaviour of migrant women alone was monitored and not that of men, and that only women were threatened with expulsion on moral grounds.

Over time we thus see continuities when it comes to illegality. In the first place, poor migrants were never welcome and were often deported, although not all deportations sprang from illegality. Both men and women were evicted if they lacked visible means of subsistence, but women were more often expelled than men on moral grounds and these grounds almost always had a sexual connotation (Henkes I995; Mak 200I; Lucassen 2002; Moloney 2006). Deportability was not necessarily the same for men and women.

Secondly, state control on mobility increased with the state's interest in welfare and labour market regulation. This principle was more strongly enforced in highly developed post war welfare states (especially in North-Western Europe), which tended to rely more on a protected labour market, a high level of migration control and other types of regulations that created barriers for migrants (Esping-Andersen I990; Faist 1997; Jordan \& Vogel I997; Van der Leun \& Kloosterman 2006). Stronger links between mobility control and labour market access worked out differently for men and women since the labour market is highly segregated according to gender (De Groot \& Schrover I995).

In the third place, the desire to control migration predated the ability to do so. The gap that occurred between the desire and the ability to control was on some occasions filled by private institutions. Restrictions on mobility were frequently put in place without the ability or wish to enforce them. They were not meant to actually impose control, but rather to create the impression of being in control. The idea that illegality poses a security risk was reinforced in later years, as we will discuss below. Both the nature of the risk posed by their migration and 
the risks they ran as illegal migrants were perceived differently for men and women.

\subsection{Illegality from a global perspective}

Illegality is related to the state's wish and ability to control mobility and is not confined to any migration regime in particular (Ghosh I998). In liberal Western democracies, however, illegality is constructed differently (see Castañeda's chapter). Garcés-Mascareñas makes it clear in her chapter that the absence of liberal democratic traditions in South-East Asia leads to different kinds of illegality for men and women. Ahmad and Moors and De Regt emphasise in their respective chapters the importance of cultural norms, not only for deciding who is illegal, but also for the agency of the people involved. In this section we will first discuss the various options available to migrants to legalise their stay and how these are different for men and women. Secondly, we will look in more detail at how illegality is constructed per region and how this works out for men and women.

Differences between illegal and legal migrants are not the same in all countries. In US literature, the boundaries between legal and illegal migration are often depicted as blurred. Many illegal immigrants improve their position over time (in terms of job mobility and income) and eventually legalise their residence (Chavez I99I, I994; Massey \& Espinosa 1997). Legal migrants are more or less in the same unfavourable position as many illegal immigrants (except for their legal status), as long as they are newcomers at the lowest rungs of the social ladder (Mahler 1995).

The possibilities of becoming legal are not the same in all countries. Italy, France, Spain and Greece have recently granted large-scale amnesties (Ruspini 2000; Apap, De Bruycker \& Schmitter 2000). Other states have gone in the opposite direction. Countries such as the Netherlands and Germany stay away from large-scale regularisations. In fact, they are increasingly looking for ways to take away residence rights from unwanted immigrants, such as those who are considered to be a threat to public order. Sometimes, states actively adapt their rules to illegalise certain categories of people (Van der Leun 2003). Until I997, migrants from the Czech Republic to Canada, for instance, did not require a visa. Although the arrival of Czech Roma was considered undesirable, the Canadian government could not label them illegal (Kernerman 2008). The increasing number of Czech Roma, however, led to a policy change. In 1997 the Canadian government introduced visa regulations for migrants from the Czech Republic. The 
Roma were unable to acquire a visa, making the arrival of those who came after I997 illegal.

In recent decades as well as in the more distant past, people became illegal when the countries they lived in ceased to exist or when citizenship in their country of origin was denied - as happened to the Muslim Rohingyas, who were made stateless by the Myanmar government in the I970s (Kaur 2007). When the Soviet Union in I99I dissolved into fifteen independent states, mobility that had previously been internal became cross border migration. Since people from Chechnya could very seldom acquire permission to move to many of the other former states, their mobility became illegal. People became illegal migrants when they fled without papers to countries that had not signed the I95I Geneva Convention Relating to the Status of Refugees - such as Malaysia - and thus could not make an asylum claim. In countries that had signed the I95I Convention, 'undocumented' implied reduced deportability but not illegality. In countries that had not signed the convention, illegality and failure to prove an identity are the same. This resembles the fate of some migrants who were described in the historical overview.

In Asia illegality is not countered by large-scale amnesties, but rather by large-scale deportations. Thailand and Malaysia are currently the two main destinations for illegal migrants in Asia (Hedman 2008). In the late I970s, during the Indochina refugee crisis, the Malaysian and Thai governments engaged in so-called push-backs of refugees. In Malaysia a task force was established with the official assignment to stop landings by Vietnamese boat people. Vessels were pushed back into the sea and assisted out of Malaysian waters. Thailand sent back refugees over the Thai-Cambodian land border into the Cambodian mine fields, killing several thousand of them.

The Malaysian government declared periods of amnesty, during which illegal migrants were encouraged to return 'voluntarily' followed by crackdowns on the illegal migrants who remained. Deportations are routine and large-scale in Thailand and Malaysia, though they are also on the rise in European countries. In 2006, for instance, the UK 'removed' 29,040 individuals, the vast bulk of whom had applied for asylum (Gibney 2008). It was the largest number of deportations ever in the UK. A huge gap exists between the number of foreigners eligible for deportation and the numbers actually deported. Deportation has in recent years become more of a symbolic than a practical power for liberal states. States are reluctant to use public displays of force, particularly against women and children. As a rule, the deportability of women and children is less than that of men. Rather strikingly, the expansion of deportations in Britain is based on reducing the number of people receiving asylum, not on reducing the level of illegal migration. 
The explanation lies in registration. Both asylum applications and removals are officially registered. These registrations can be used publicly to monitor the adequacy of government performance. The number of illegal migrants cannot be determined, and thus the failings of the government are less obvious.

As this section has made clear, migrants can become legal or illegal in various ways. Options are not the same for men and women. Here we will look at five areas in which differences occur: marriages, asylum procedures, work, giving birth to a legal baby and special programmes for prostitutes.

In the first place, governments in sending and receiving societies ascribe different rights to migrant men and women regarding gaining or retaining nationality after marriage (De Hart 2003; Fahrmeir 2007: I26-I33). In the past, women could more easily acquire a new nationality through marriage, generally speaking, and thus legalise their residence, than men (Boris I995). Such differences have disappeared in recent decades, but they did exist in many countries well into the second half of the twentieth century.

Secondly, migrants can legalise their residence via asylum procedures. So far, it is not clear if the refugee recognition rate is different for men and women, although some authors have shown that under certain conditions, women are much less frequently granted refugee status than men (cf. Spijkerboer 2000; Calavita 2006; Van Liempt's chapter in this volume). Currently, the discussion is not only whether the grounds are the same, but whether they should be, and whether gender-related violence should be a ground for asylum. According to the I95I Convention, the ground for asylum is defined as a wellfounded fear of persecution on account of race, religion, nationality, membership in a particular social group or political opinion. Gender or gender-related harm is absent as a category of persecution. Genderrelated violence is seen in current discussions as something that can happen only to women. If reference is made to men, it is to homosexuals (Oxford 2005). It is much more common for women than for men to be the victims of sexual violence, and those who have been victims of what is called accidental or arbitrary rape (which is seen as a sad but common part of regular warfare) are not regarded as persecuted. Women who were raped in order to retrieve information about their families (such as the whereabouts of husbands or sons) were not granted asylum in the past. In recent years there has been a change in asylum policies and laws. In the US, immigrant women can gain asylum and legal entry by proving they are being persecuted on account of female circumcision, honour killings, domestic violence, coercive family planning, forced marriages or repressive social norms (Oxford 2005). This is also true for some European countries such as Germany. 
Asylum seekers in the US stand a better chance of having their request approved if they mention female circumcisions at the hearings rather than explaining their role in a resistance movement. Stories about resistance are almost never acknowledged as a ground for asylum for women (while they are for men), whereas the mentioning of female circumcision is (Oxford 2005).

A third option for legal migration is through work in the formal economy. This is problematic since much of the work that can be regarded as typical immigrant women's work, such as the work of domestics, au pairs, prostitutes, cleaners and women working in restaurants and the domestic industries, is informal (Schrover, Van der Leun \& Quispel 2007). Immigrant men are more successful than women in finding work in the formal economy. Yet, recently there have been situations in which domestic work does offer opportunities for legal residence. One of the few ways to enter Italy or Spain legally, for instance, is through annual quotas established in sectors of the economy where labour shortages appear to exist - primarily agriculture, construction and domestic service. A simple note from an employer in these sectors is sufficient to apply for legal status. For those who enter illegally or reside past the period of their initial employment on these quotas, legalisation programmes are periodically launched. However, the effect of this policy is that women who want to migrate to countries such as Italy or Spain, and subsequently want to legalise their status, are confined to domestic work (Calavita 2006: 120).

A fourth way to legalise residence, described in this book in Castañeda's chapter, is by giving birth to a so-called anchor baby. This is an option open to women who are illegal residents in the US. According to the jus soli principle, babies born on US soil are US citizens from birth. In the past mothers have received permanent residency status as mothers of US citizens. In countries that follow the jus sanguinis principle, such as the Netherlands and Germany, this in not an option. In Germany, women residing illegally who give birth have to acquire a birth certificate for their children. Reporting to the authorities in order to get this certificate puts them at risk of deportation. Still, if they do not acquire this birth certificate they run the risk of not having any parental rights over the child, who becomes not only an illegal resident but one whose mother is not legally recognised as its parent. The child can be 'legalised' if a German man or legal resident of Germany acknowledges paternity. Castañeda reports on fake acknowledgements of paternity and situations in which these were sold and bought.

Whereas giving birth is a legalisation option today in the US, in the past it has been a reason for eviction. In her chapter, Reinecke describes how in 1900 Polish women who were found to be pregnant were routinely evicted from Germany. Today in Malaysia, all immigrant 
women, including those whose residence is legal, must submit to annual gynaecological tests, and if they are pregnant they are immediately deported. If they manage to evade deportation, they become illegal migrants (see Garcés-Mascareñas' chapter).

A last option for legalisation has to do with programmes that some countries have for women who testify against traffickers (Andrijasevic 2004). A 2004 EU Council Directive provides for the issuing of residence permits to migrants who are victims of trafficking in human beings and who cooperate with the authorities. Countries like Italy, Belgium and the Netherlands already had these arrangements before 2004 (Truong 2003). Women receive temporary residence and work permits if they take part in legal proceedings. These rights are usually granted only for the duration of the criminal procedure, but women have regularly been granted permanent rights on humanitarian grounds after the end of the procedures.

Overall, it is difficult to say whether illegal women stand a better chance of legalising their residence than men. What is clear is the fact that options are different for men and women. For a long time, legalisations via work in the formal economy favoured men, but recently there have been developments that favour women. Likewise, asylum procedures originally seemed to create more options for men, but in recent years options for women seem to have improved. Legalisation via marriage, childbirth or testifying against traffickers offers more possibilities to women.

\subsection{Regional differences}

We now look in more detail at differences and similarities between regions. The responses of governments towards illegal migration are often contradictory. The US, for instance, polices the Mexican border in a spectacular manner but does not take action to dampen the demand for illegal immigrants on the US side of the border. As a result, the policy is highly ineffective (Zolberg I990; Abraham \& Van Schendel 2005: I4). One reason for the failure of the state to control illegal migration is that both employers and governments profit from the cheap labour. The repression of illegal migration is expensive for states and employers alike (Djaji 1997).

The willingness to reduce illegal migration is thus influenced by the demand for cheap labour. Debates on illegal migration and protection of the labour market from foreign workers tend to broaden out to issues of security. This was not only true for Westerns societies before the Second World War, but also for other societies in recent decades (see for example Morita \& Sassen I994 on Japan). 
Another reason why the US policy of controlling illegal migration persists long after its ineffectiveness has become apparent is to convince the general public that politicians have not lost control over immigration (Cornelius 2005). More than half of the US public believes that the government should be spending more to end illegal immigration along the US-Mexican border. Furthermore, in the post-9/II era, immigration control and anti-terrorism efforts are conflated, and a continuing show of force on the border symbolises the nation's resolve to fight terrorism even if it does nothing to enhance security. Similar security claims are made in other regions, as when borders moved eastward after the enlargement of the EU (Mitsilegas 2002). Illegal migration was also associated with security in earlier decades, as our historical overview showed. The association between illegality and security is highly gendered (Chock I99I). The discourse on illegality along the US-Mexico border - which was frequently described as a zone of danger, darkness and violence, with illegal migration that was referred to as a 'crisis that will not go away' - never mentioned women. The association between security and illegality did not increase continuously over time. Rather it slackened during economic upturns.

The difference between action and effect has been observed in the historical overview above. It has to do with creating an impression of being in control rather than actually exercising control. Political and public discourse tends to revolve around the number of illegals in a country (Van der Leun 2003). The inability to assess the numbers of illegals creates the feeling that the government is not in control (Geddens 2005; De Haas 2007). Often, the actions undertaken by authorities are not the most effective in terms of reducing the numbers of illegal migrants. Governments today spend a lot of money in an attempt to stop illegal migrants from entering their country. Efforts by the British government, for instance, to stop migrants entering the UK via the Eurotunnel are extremely costly. In reality, most illegal migrants enter in legal ways - as tourists or exchange students, for instance and overstay their visas. Britain is not the only country where most illegal migrants enter the country legally. In Japan many illegal migrants originally entered the country legally as unpaid trainees in large firms or students at Japanese language schools (Spencer I992).

In our historical overview we showed that a gap develops between the desire to control and the ability to do so. When and where this gap forms depends on the power of states and thus on the process of state formation. Delegating control to private institutions can fill the gap. In recent decades in Malaysia, private 'volunteer vigilantes' have played a prominent role in exercising control (Hedman 2008; Garcés-Mascareñas' chapter in this volume). They round up illegal migrants, often including refugees who have been recognised by the UNHCR. Since 
2005 the vigilantes have had the right to bear firearms and use them. They can stop suspects, and search them and demand documents, and they do not need a warrant to arrest or enter premises. They track down illegal immigrants and seek them out in places where they converge over weekends, such as shopping malls.

A similar development occurred in South Africa (Landau \& Monson 2008). In recent decades the South African government has allowed for the emergence of a semi-parallel authority system responsible for monitoring illegal migrants. The system did not emerge in a total absence of state control. It is to some extent used - but not controlled by the state.

Australia has developed a different method of outsourcing control in recent decades (Hyndman \& Mountz 2008). The so-called Pacific Solution means that Australia refuses migrants arriving by boat to land on its shores. The detention and processing of unwanted migrants is subcontracted out to small, poor islands north of Australia (Manus, Papua New Guinea, Nauru, Christmas Island and the Cocos Islands). The Australian government pays millions of AUS dollars to these islands for the processing and detention of illegal migrants.

Whether governments profit from reducing illegality depends on how they gain from illegal migration both economically and politically (as was also true in the past). For migrants it is sometimes more advantageous to remain illegal. In Greece, for instance, migrants find work more easily if they are illegal than after legalisation (Lazaridis \& Poyago-Theotoky 1999). Especially for certain types of employment, such as seasonal work in agriculture and tourism, employers are unwilling to pay the relatively high costs that come with legal employment. For this reason, migrants in Greece who had already been legalised but still had to confirm their status by showing they had worked legally for a certain length of time, lapsed back into illegality (Glytsos 2005). Furthermore, people do not migrate illegally only when legal channels are unavailable. In Asia, legal migration is complex and costly and illegal migration is cheaper and faster (Skeldon 2000).

The chapters in this volume show that there is no clear distinction between legality and illegality, neither in Western societies nor in nonWestern societies, and neither in the period before the Second World War nor in the period after the war. The various chapters show that as far as migration is concerned, there is no such thing as a legal-illegal dichotomy. Furthermore, in the literature a certain linearity is assumed: illegal becomes legal or vice versa. However, in reality people move repeatedly in and out of illegality, as Moors and De Regt's chapter shows. This is supported by other research. For instance, asylum seekers on their way to Europe who received asylum, and thus a legal status, in Ukraine migrated onwards to Western Europe, and as such 
became illegal once again (Uehling 2004). In the same vein, legalised immigrants in Italy have been found to keep working in jobs illegally or sometimes even to revert to an illegal status again some time after an amnesty (Ruspini 2000; Reyneri 200I).

Moors and De Regt's chapter also shows that legal organisations follow illegal practices, and what is legal in one country is illegal in another. Labour contracts signed in one country are invalid in another country, making migration to that country illegal. Similarly, Van Liempt shows in her chapter how legality and illegality can intertwine; people enter countries with the required papers after having provided false information in order to get those papers. Women lie about their income in order to meet visa income requirements, or they lie about their marital status and about having children for the same reason.

Ahmad points out that there is relatively little independent migration of women from or within Pakistan, even without it being explicitly forbidden. Women's mobility (leaving the house for school, work or to attend rituals) has become highly restricted in Pakistani society. At the same time, increasing numbers of middle and lower middle-class men from the rural Punjab set off for Europe, in spite of the extensive laws in place to prohibit it. This underlines the importance of cultural and social norms above purely 'legal' or bureaucratic forms of control.

From the neo-classical perspective, the cost-benefit analysis of illegal migration is believed to work out differently for men and women because high-risk illegal migration is expensive. The assumption is that families and networks are more likely to invest in the migration of men rather than in the migration of women, because the migration of men is believed to be more profitable for families left behind. Ahmad's chapter shows that the decision to migrate illegally is not necessarily a product of collectively made, rational, economic calculations. In some cases it is an individual decision made outside of and against the wishes of the household. Fostered within communities of often youthful men, it is borne out of a lust for adventure, which is associated with locally entrenched masculine ideals.

As has been pointed out above, research and debate on the illegal migration of women are dominated by a victimhood approach. Migrant women and their spokespersons tap into this discourse. However, migrant women are often much less victims than they are made out to be. Moors and De Regt show in their chapter how women use the victimhood discourse to avoid accusations of selfishness. It seems that for women, economic migration (legal or illegal) can only be legitimised by extreme hardship.

The effects of migration on those who stay behind differ according to the specific context. Earlier research has shown that the migration of men offers advantages to the women who stay behind, since they 
profit from an increased income and gain independence in the absence of their husbands (Brettell 1986; Reeder 2003). However, Ahmad points out that the consequences of the emigration of men for the women who stay behind are ambiguous at best. It seems not uncommon for women to experience greater seclusion and confinement to their homes once their households are lifted out of poverty by remittances. Some migrant men use their resources to impose stricter purdah and to increase their own social position within the communities, in which confining women to the home confers honour and prestige to the household.

In her chapter on foreign workers in Malaysia, Garcés-Mascareñas shows that illegality is not always a disadvantage. Domestic workers, as 'non-workers', are not included in the Employment Act. This is also true for domestic workers in many other countries (Schrover et al. 2007). Since they are regarded as 'family members', domestic workers are the only foreign workers in Malaysia who are not obliged to leave the country after five or seven years. They can reside in Malaysia almost interminably as perpetual temporary migrants, while men cannot. Illegal migrants to Malaysia also do not have to pay recruitment fees, exit costs, annual levies and insurance and do not have medical check-up expenses. They have more freedom than legal migrants to change jobs and to negotiate wages and labour conditions. Similarly, Moors and De Regt describe how domestic workers in the Middle East who work illegally - without a sponsor and thus without a permit to stay - are better off than those whose residence is legal. They are less dependent on their employers, earn higher incomes and have more freedom. In the case presented by Moors and De Regt, legal migrants do not have more rights than illegal ones. The same is true for the many women from Latin America who work as domestic servants in Israel. It is almost impossible to migrate legally to Israel as a nonJewish labour migrant. The rights of those who do are so severely restricted that it is more advantages to migrate illegally, despite the drawbacks (Raijman, Schammah-Gesser \& Kamp 2003). Because illegality offers certain advantages, some migrants may prefer to become or stay illegal. The 'cost' of illegality is influenced by the chances migrants run of being discovered, arrested and deported (Todaro \& Maruszko 1987). We have shown that the chances of being found out as well as deportability are different for men and women.

\subsection{Conclusion}

Going back to the questions first posed in this book, we can conclude that illegality is constructed differently for men and women across both 
time and space. The historical overview clarifies two issues. Firstly, even if the term 'illegal' is a modern one, and if national laws on entry, exit and residence are recent, restrictions on mobility are not. Secondly, legality and illegality have less to do with borders and states than with work, potential poverty and potential public disorder. We can see a remarkable continuity regarding these two points. Over time and space, migrants in general have been perceived as poor. The likelihood that they will become a public charge (and for women this is clearly linked to morality) has always been an important argument in the call for restriction and control.

The studies in this book show the importance of the contexts within which the forms of illegality are produced, both for men and women. The historical and global perspectives demonstrate that the distinction between legal and illegal is not always clear, and it is only relevant when and where migrants who stay or enter legally have more rights than those who do so illegally. In many Western countries, there is a huge difference between legal and illegal migration, whereas in other parts of the world this is not always the case.

The ways that migrants and states respond to illegality depend on how the costs and benefits of both legality and illegality are perceived. In analysing these, a distinction must be made between the effects on migrants, on the sending societies and on the receiving societies. Sending and receiving societies will have different interests in the construction of illegality, and these interests work out differently for men and for women.

For migrants, it is not only relevant to look at how the rights of illegal migrants compare with those of legal migrants, but also at how the rights of men and women in the sending society compare with the rights of illegal migrants in the receiving society. If there are substantial differences between the rights of illegal and legal migrants in the receiving society, migrants will gain from legalisation programmes or from migrating legally. If men and women have few rights in their sending society, their illegal position in the receiving country can be an improvement, or at least can be perceived as such, despite the disadvantages associated with an illegal status. Women who have very few rights in their sending societies, with no access to formal labour participation and a strong restriction of movement, have little to lose from becoming illegal through migration. Their illegal position in the receiving societies may have its disadvantages, but their position is not worse or may even be better than that in their sending society. The 'costs' of illegal migration are not the same for men and women. Men engage more in high-risk, expensive migrations, but the profits from these endeavours are likewise assessed to be high. Women engage in low-risk 
migrations that are less costly, while their low visibility and smaller chance of deportation reduce these costs even further.

As we have explained, illegality is not always a disadvantage. It depends on the opportunities men and women have in the sending and receiving societies, and the difference that legal or illegal migration is going to make in this respect. The advantages or disadvantages that migrant women and men encounter have to be contrasted with their position prior to migration. This differs according to gender, but it also depends on the country the migrants come from and on the period during which the migratory process took place.

Sending states do profit from the remittances sent by legal and illegal migrants. This means that they have little or no incentive to control emigration, even when it is illegal. Still, a difference in the amount of remittances sent by men and women can lead to different approaches in their attempt to control illegal migration. Sending states can also be held responsible by NGOs and other institutions for the risks, actual and perceived, that illegal migrants run. These risks are seen as being different for men and women. The idea that migrant women run a high risk of ending up as prostitutes has led to the restriction of their movement. Nevertheless, these bans have not stopped, nor have they reduced the migration of women. What they have accomplished is to drive women into illegal forms of travel.

The responses to illegal migration in receiving states are influenced firstly by the nature of the poor relief or welfare system. Receiving states with elaborate poor relief or welfare systems will put more emphasis on the control of migration. As we have shown above, states assess the likelihood of men becoming a public charge differently than that of women. Secondly, a highly regulated labour market will lead to a higher degree of migration control. If migrant women are more likely than men to be found in the informal sectors of the economy, there will be less pressure on the receiving states (by unions, for instance) to control their migration. Thirdly, receiving countries (and employers, more precisely) do profit from the labour of illegal migrants, who are cheaper, more flexible and more docile than legal workers. In labour markets that are highly segregated according to gender, this will affect men and women differently. Fourthly, if migrants are perceived as a threat to public order, this will lead to strong migration control. In the past, both migrant men and women have been perceived as social threats, but the nature of this threat is regarded very differently. In the case of women, we see an emphasis on the protection of the receiving society against vice. This is not so for men. Fifthly, we have shown above that the state's response to illegal migration is strongly influenced by the chances that migrants have to migrate legally and to acquire legal residence. As we have shown, the possibilities to acquire le- 
gal residence via asylum, work, legalisation programmes, marriage, childbirth and witness protection provisions for those who report on their traffickers are not the same for migrant men and women.

Overall, it can be said that the chances, opportunities and advantages of legal and illegal migration are different for men and women, who make their choices accordingly. The construction of what is legal and illegal also differs according to gender, as do the responses of sending and receiving states towards illegal migration. The illegal migration of men is associated with fears of losing control over the labour market. That of women is strongly associated with questions of morality. Both associations can lead to restrictions on exit, entry and residence. The threats linked to the illegal migration of women have frequently been used to legitimise these restrictions and to make them appear humanitarian.

\section{References}

Abraham, Itty \& Willem van Schendel (2005), 'Introduction: The making of illicitness', in Willem van Schendel \& Itty Abraham (eds.), Illicit flows and criminal things. States, borders and the other side of globalization, I-37. Bloomington: Indiana University Press.

Agustin, Laura (2005), 'Migrants in the mistress's house: Other voices in the "trafficking" debate', Social Politics: International Studies in Gender, State and Society I2 (I) Spring: 96-II7.

Andrijasevic, Rutvica (2004), Trafficking in women and the politics of mobility in Europe. PhD thesis. Utrecht: Utrecht University.

Apap, Joanna, Philippe de Bruycker \& Catherine Schmitter (2000), Regularisations of illegal aliens in the European Union: Summary report of a comparative study. Brussels: Bruylant Publishers.

Bade, K. J. (2000), Europa in Bewegung: Migration vom späten 18. Jahrhundert bis zur Gegenwart. Munich: C.H. Beck.

Bade, Klaus J., Pieter Emmer, Leo Lucassen \& Jochen Oltmer (eds.) (2007), Enzүklopädie Migration in Europa vom 17. Jahrhundert bis zur Gegenwart. Paderborn/Munich: Wilhelm Fink Verlag/Ferdinand-Schöningh-Verlag.

Baron, Nick \& Peter Gatrell (2003), 'Forum: Population movements and population politics from World War I to World War II. Population displacement, state-building, and social identity in the lands of the former Russian Empire, I9I7-23', Kritika: Explorations in Russian and Eurasian History 4: 51-I00.

Berman, Jacqueline (2003), '(Un)popular strangers and crises (un)bounded: Discourses of sex-trafficking, the European political community and the panicked state of the modern state', European Journal of International Relations 9: 37-86.

Bland, Lucy (2005), 'White women and men of colour: Miscegenation fears in Britain after the Great War', Gender a History I7 (I): 29-6r.

Boris, E. (I995), 'The racialized gendered state: Constructions of citizenship in the United States', Social Politics 2 (2): I60-I8I.

Brennan, Denise (2004), 'Women work, men sponge, and everyone gossips', Anthropological Quarterly 77 (7) Fall: 705-733.

Brettell, Caroline B. (I986), Men who migrate, women who wait: Population and history in a Portuguese parish. Princeton: Princeton University Press. 
Brinkmann, Tobias (2008), “'Travelling with Ballin”: The impact of American immigration policies on Jewish transmigration within Central Europe I880-I9I4', IRSH 53 (forthcoming).

Brubaker, Rogers (I992), Citizenship and nationhood in France and Germany. Cambridge/ London: Harvard University Press.

Calavita, Kitty (2006), 'Gender, migration, and law: Crossing borders and bridging discipline’, IMR 40 (I) Spring: IO4-I32.

Camiscioli, Elisa (200I), 'Producing citizens, reproducing the "French race": Immigration, demography, and pronatalism in early twentieth-century France', Gender \& History I3 (3): 593-62I.

Caplan, Jane \& John Torpey (eds.) (200I), Documenting individual identity: The development of state practices in the modern world. Princeton: Princeton University Press.

Chan, Sucheng (I99I), Entry denied: Exclusion and the Chinese community in America, 1882-1943. Philadelphia: Temple University Press.

Chapkis, Wendy (2003), 'Trafficking, migration, and the law: Protecting innocents, punishing immigrants', Gender and Society 7 (6) December: 923-937.

Chavez, L. (I99I), 'Outside the imagined community: Undocumented settlers and experiences of incorporation', American Ethnologist i8: 257-278.

Chavez, L. (I994), 'The power of imagined community: The settlement of undocumented Mexicans and Central Americans in the United States', American Anthropologist 96 (I): 52-73.

Chock, Phyllis Pease (I99I), “Illegal aliens” and "opportunity”: Myth-making in congressional testimony’, American Ethnologist I8 (2) May: 279-294.

Cornelius, Wayne A. (2005), 'Controlling "unwanted” immigration: Lessons from the United States, I993-2004', JEMS I (4): 775-794.

Cresswell, Tim (2006), On the move: Mobility in the modern Western world. New York/London: Routledge.

De Genova, Nicholas P. (2002), 'Migrant “illegality” and deportability in everyday life', Annual Review of Anthropology 3I: 4I9-447.

De Groot, Gertjan \& Marlou Schrover (eds.) (I995), Women workers and technological change in Europe in the nineteenth and twentieth centuries. London: Taylor \& Francis.

De Haas, Hein (2007), The myth of invasion: Irregular migration from West Africa to the Maghreb and the European Union. Oxford: International Migration Institute.

De Hart, B. (2003), Onbezonnen vrouwen: Gemengde relaties in het nationaliteitsrecht en het vreemdelingenrecht. Amsterdam: Aksant.

Djaji, Slobodan (I997), 'Illegal immigration and resource allocation', International Economic Review 38 (I) February: 97-II7.

Doezema, Jo (2005), 'Now you see her, now you don't: Sex workers at the UN trafficking protocol negotiations', Social Legal Studies I4: 6r-89.

Donato, Katharine M., Donna Gabaccia, Jennifer Holdaway, Martin Manalansan \& Patricia R. Pessar (2006), 'A glass half full? Gender in migration studies', IMR 40 (I) Spring: 3-26.

Eltis, David (ed.) (2002), Coerced and free migration: Global perspectives. Stanford: Stanford University Press.

Erel, Umut (2003), 'Soziales Kapital und Migration: Die Kraft der Schwachen?', in Castro Varela, Maria Do Mar \& Dimitria Clayton (eds.), Migration, Gender, Arbeitsmarkt; Neue Beitrage zu Frauen und Globalisierung, I54-I85. Königstein/Taunus: Ulrike Helmer Verlag.

Esping-Andersen, G. (I990), The three worlds of welfare capitalism. Cambridge: Polity Press. 
Faist, T. (I997), 'From common questions to common concepts', in T. Hammar, G. Brochmann, K. Tamas \& T. Faist (eds.), International migration, immobility and development: Multidisciplinary perspectives, 247-276. Oxford: Berg.

Fahrmeir, A. (2000), Citizens and aliens: Foreigners and the law in Britain and the German States 1789-1870. New York/Oxford: Berghahn.

Fahrmeir, Andreas (2003), 'Law and practice: Problems in researching the history of migration control', in Andreas Fahrmeir, Olivier Faron \& Patrick Weil (eds.), Migration control in the North Atlantic world: The evolution of state practices in Europe and the United States from the French Revolution to the Inter-War period, 30I-3I5. New York/Oxford: Berghahn.

Fahrmeir, Andreas (2007), Citizenship. The rise and fall of a modern concept. New Haven: Yale University Press.

Fahrmeir, A., O. Faron \& P. Weil (eds.) (2003), Migration control in the North Atlantic World: The evolution of state practices in Europe and the United States from the French Revolution to the Inter-War period. New York: Berghahn.

Feldman, David (2003a), 'Migrants, immigrants and welfare from the old Poor Law to the welfare state', Transactions of the Royal Historical Society I3: 79-IO4.

Feldman, David (2003b), 'Was the nineteenth century a golden age for immigrants? The changing articulation of national local and voluntary controls', in Andreas Fahrmeir, Olivier Faron \& Patrick Weil (eds.), Migration control in the North Atlantic world: The evolution of state practices in Europe and the United States from the French Revolution to the Inter-War period, I67-I77. New York/Oxford: Berghahn.

Fraser, Angus (1992), The Gypsies. Oxford: Blackwell.

Gabaccia, Donna (I997), "The "Yellow peril" and the "Chinese of Europe": Global perspectives on race and labor, I8I5-I930', in Jan Lucassen \& Leo Lucassen (eds.), Migration, migration history, history: Old paradigms and new perspectives, I77-I96. Bern: Peter Lang.

Geddens, Andrew (2005), 'Chronicle of a crisis foretold: The politics of irregular migration, human trafficking and people smuggling in the UK', BJPIR 7: 324-339.

Ghosh, B. (I998), Huddled masses and uncertain shores: Insights into irregular migration. The Hague/Boston/London: Martinus Nijhoff.

Gibney, Matthew J. (2008), 'Asylum and the expansion of deportation in the United Kingdom', Government and Opposition 43 (2): I46-I67.

Glytsos, Nicholas P. (2005), 'Stepping from illegality to legality and advancing towards integration: The case of immigrants in Greece', IMR 39 (4) Winter: 8I9-840.

Gosewinkel, Dieter (200I), Einbürgern und Ausschliessen: Die Nationalisierung vom Deutschen Bund bis zur Bundesrepublik Deutschland. Vol. I50, Kritische Studien zur Geschichtswissenschaft. Göttingen: Vandenhoeck \& Ruprecht.

Green, Nancy L. \& Francois Weil (eds.) (2007), Citizenship and those who leave: The politics of emigration and expatriation. Urbana/Chicago: Illinois University Press.

Hahn, Sylvia (2005), 'Fremd im eigenen Land: Zuwanderung und Heimatrecht im I9. Jahrhundert', Pro Civitate Austriae, NF. I0: 23-44.

Hahn, Sylvia, Andrea Komlosy \& Ilse Reiter (eds.) (2006), Ausweisung - Abschiebung Vertreibung in Europa, 16-20. Jahrhundert. Innsbruck: Studienverlag.

Haynes, Dina Francesca (2004), 'Used, abused, arrested and deported: Extending immigration benefits to protect the victims of trafficking and to secure the prosecution of traffickers', Human Rights Quarterly 26: 22I-272.

Heckmann, Friedrich (2004), 'Illegal migration: What can we know and what can we explain? The case of Germany', IMR 38 (3) Fall: IIO3-II25.

Hedman, Eva-Lotta E. (2008), 'Refuge, governmentality and citizenship: Capturing "illegal migrants” in Malaysia and Thailand', Government and Opposition 43 (2): 358-383. 
Henkes, Barbara (I995), Heimat in Holland: Duitse dienstmeisjes 1920-1950. Amsterdam: Babylon-de Geus.

Higgs, E. (2004), The information state in England: The central collection of information on citizens since 1500. Houndmills: Palgrave Macmillan.

Hochstadt, Steve (I999), Mobility and modernity: Migration in Germany 1820-1989. Ann Arbor: University of Michigan Press.

Hoerder, D. (2002), Cultures in contact: World migrations in the second millennium. Durham: Duke University Press.

Hollifield, James (1998), 'Migration, trade and the nation-state: The myth of globalization', UCLA Journal of International Law and Foreign Affairs 3(2): 595-636.

Hyndman, Jennifer \& Alison Mountz (2008), 'Another brick in the wall? Neo-refoulement and the externalization of asylum by Australia and Europe', Government and Opposition 43 (2): 249-269.

International seminar on cross border movements and human rights, January 9-Io, 2004, New Delhi, India (Report on this seminar published by the Centre for Feminist Legal Research).

Jandl, Michael (2007), 'Irregular migration, human smuggling, and the Eastern enlargement of the European Union', IMR 4I (2) Summer: 29I-3I5.

Jordan, B. \& D. Vogel (1997), Which policies influence migration decisions? A comparative analysis of qualitative interviews with undocumented Brazilian immigrants in London and Berlin as a contribution to economic reasoning. Bremen: Zentrum für Sozialpolitik/Universität Bremen.

Kaur, Amarjit (2007), Refugees and refugee policies in the Asia-Pacific, UNEAC Asia Papers. www.une.edu.au/asiacenter/UNEAC_Asia_Papers_I2-I9.html

Kernerman, Gerard (2008), 'Refugee interdiction before heaven's gate', Government and Opposition 43 (2): 230-248.

Komlosy, Andrea (2003), 'Empowerment and control: Conflicting central and regional interests in migration within the Habsburg monarchy', in Andreas Fahmeir, Olivier Faron \& Patrick Weil (eds.), Migration control in the North Atlantic world: The evolution of state practices in Europe and the United States from the French Revolution to the InterWar period, I53-I66. New York: Berghahn.

Komlosy, Andrea (2004), 'Grenzen und die Steuerung der Binnenmigration in den österreichischen und böhmischen Ländern im I8. und I9. Jahrhundert', in Mathias Beer \& Dittmar Dahlmann (eds.), Über die trockene Grenze und über das offene Meer: Binneneuropäische und transatlantische Migrationen im 18. und 19. Jahrhundert, 263288. Essen: Klartext.

Koser, Khalid (2005), 'Irregular migration, state security and human security'. Paper prepared for the Policy Analysis and Research Programme of the Global Commission on International Migration September.

Landau, Loren B. \& Tamlyn Monson (2008), 'Displacement, estrangement and sovereignty: Reconfiguring state power in urban South Africa', Government and Opposition 43 (2): 315-336.

Langewiesche, Dieter \& Friedrich Lenger (I987), 'Internal migration: Persistence and mobility', in Bade Klaus J. (ed.), Population, labour and migration in 19th-and 2oth century Germany 87-Ioo. Leamington Spa: Berg; St. Martins Press.

Lazaridis, Gabriella \& Joanna Poyago-Theotoky (I999), 'Undocumented migrants in Greece: Issues of regularization', International Migration 37 (4): 715-740.

Lees, Lynn Hollen (1998), The solidarities of strangers: The English poor laws and the people, 1700-1948. Cambridge: Cambridge University Press.

Lucassen, Leo (1996), Zigeuner: Die Geschichte eines polizeilichen Ordnungsbegriffes in Deutschland 1700-1945. Cologne: Böhlau-Verlag. 
Lucassen, Leo (1997), 'Eternal vagrants? State formation, migration, and travelling groups in Western Europe, I350-I9I4', in J. Lucassen \& L. Lucassen (eds.), Migration, migration history, history: Old paradigms and new perspectives, 225-252. Bern: Peter Lang.

Lucassen, Leo (1998), 'The Great War and the origins of migration control in Western Europe and the United States (I880-1920)', in A. Böcker, K. Groenendijk, T. Havinga $\&$ P. Minderhoud (eds.), Regulation of migration. International experiences, 45-72. Amsterdam: Spinhuis.

Lucassen, Leo (2002), 'Administrative into social control: The aliens police and foreign female servants in the Netherlands (I918-I940)', Social History 27 (3): 327-342.

Lucassen, Leo (2005), The immigrant threat: The integration of old and new migrants in Western Europe since 1850. Urbana/Chicago: The University of Illinois Press.

Lucassen, Leo (2007), 'Migration and world history: Reaching a new frontier', International Review of Social History 52 (I): 89-96.

Lucassen, Leo, Wim Willems \& Annemarie Cottaar (1998), Gypsies and other itinerant groups: A socio-historical approach. London/New York: MacMillan; St. Martin's Press.

Mahler, S.J. (1995), American dreaming: Immigrant life on the margins. Princeton: Princeton University Press.

Mak, Geertje (200I), 'Seksueel vreemdelingenverkeer', Gaan \& Staan, Jaarboek voor Vrouwengeschiedenis 2I: IOI-I22.

Manning, P. (2005), Migration in world history. New York/London: Routledge.

Massey, D. \& K. Espinosa (1997), 'What's driving Mexico-US migration? A theoretical, empirical and policy analysis', American Journal of Sociology I2 (4): 939-999.

McKeown, Adam (200I), Chinese migrant networks and cultural change: Peru, Chicago, Hawaii, 1900-1936. Chicago/London: University of Chicago Press.

McKeown, Adam (2004), 'Global migration, I846-I940', Journal of World History I5 (2): I55-189.

Mitsilegas, Valsamis (2002), 'The implementation of the EU acquis on illegal immigration by the candidate countries of Central and Eastern Europe: Challenges and contradictions', JEMS 28 (4): 665-682.

Moch, Leslie Page (2003), Moving Europeans: Migration in Western Europe since 1650. Indiana: Indiana University Press.

Mohapatra, Prabhu (2007), 'Eurocentrism, forced labour and global migration: A critical assessment', International Review of Social History 52 (I): IIO-II5.

Moloney, Deirdre M. (2006), 'Women, sexual orality, and economic sependency in early U.S. deportation policy', Journal of Women's History I8 (2): 95-I22.

Morita, Kiriro \& Saskia Sassen (I994), 'The new illegal immigration in Japan, I980I992', International Migration Review 28 (I) Spring: I53-I63.

Ngai, Mae M. (2004), Impossible subjects: Illegal aliens and the making of modern America. Princeton/Oxford: Princeton University Press.

Noiriel, G. (I99I), La tyrannie du national: le droit d'asile en Europe (1793-1993). Paris: Calmann-Lévy.

Okin, Susan Moller (I999), 'Is multiculturalism bad for women?', in J. Cohen, M. Howard \& M. Nussbaum (eds.), Is multiculturalism bad for women, 9-24. Princeton: Princeton University Press.

Oxford, Connie G. (2005), 'Protectors and victims in the gender regime of asylum', NWSA Journal I7 (3) Fall: 18-38.

Phizacklea, A. (1998), 'Migration and globalization: A feminist perspective', in K. Koser $\& \mathrm{H}$. Lutz (eds.), The new migration in Europe, 2I-38. London: Macmillan.

Raijman, Rebeca, Silvina Schammah-Gesser \& Adriana Kemp (2003), 'International migration, domestic work, and care work: Undocumented Latina migrants in Israel', Gender and Society I7 (5) October: 727-749. 
Reeder, L. (2003), Widows in white: Migration and the transformation of rural women, Sicily 1880-1928. Toronto: University of Toronto Press.

Reyneri, E. (200I), Migrants' involvement in irregular employment in the Mediterranean countries of the European Union. Geneva: ILO.

Rosenberg, C. (2006), Policing Paris: The origins of modern immigration control between the wars. Ithaca/London: Cornell University Press.

Ruspini, P. (2000), 'Living on the edge: Irregular immigrants in Italy', in D.A. Çinar, Gächter \& H. Waldrauch (eds.), Irregular migration: Dynamics, impact, policy options, 8I-94. Vienna: European Centre.

Sahlins, Peter (2004), Unnaturally French: Foreign citizens in the old regime and after. Ithaca/London: Cornell University Press.

Samers, Michael (200I), “Here to work": Undocumented immigration in the United States and Europe', SAIS review, XXI (I) Winter-Spring: I3I-I45.

Schlumbohm, Jürgen (I997), 'Gesetze, die nicht duchgesetzt werden: Ein Strukturmerkmal des frühneuzeilichen Staates', Geschicht und Gesellschaft 23: 647-663.

Schrover, Marlou (200I), 'Immigrant business and niche formation in a historical perspective: The Netherlands in the nineteenth century', JEMS 27 (2) April: 295-3II.

Schrover, Marlou (2002), Een kolonie van Duitsers: Groepsvorming onder Duitse immigranten in Utrecht in de negentiende eeuw. Amsterdam: Aksant.

Schrover, Marlou, Joanne van der Leun \& Chris Quispel (2007), 'Niches, labour market segregation, ethnicity and gender', JEMS 33 (4) May: 529-540.

Scott, James C. (I998), Seeing like a state: How certain schemes to improve the human condition have failed. New Haven/London: Yale University Press.

Siddiqui, Tarneen (2003), 'An anatomy of forced and voluntary migration from Bangladesh: A gendered perspective', in Mirjana Morokvasic, Umut Erel \& Kyoko Shinozaki (eds.), Crossing borders and shifting boundaries, vol. I. Gender on the move, I55-I76. Opladen: Carfax Publishing Company.

Singha, Radhika (I998), A despotism of law: Crime and justice in early colonial India. Delhi: Oxford University Press.

Sinke, Suzanne M. (2006), 'Gender and migration: Historical perspectives', IMR 40 (I) Spring: 82-103

Skeldon, Ronald (2000), 'Trafficking: A perspective from Asia', International Migration, Special issue (I): 7-30.

Soderlund, Gretchen (2005), 'Running from the rescuers: New U.S. crusaders against sex trafficking and the rhetoric of abolition', NWSA Journal I7 (3) Fall: 64-87.

Spencer, Steven A. (I992), 'Illegal migrant laborers in Japan', International Migration Review 26 (3) Autumn 754-786.

Spijkerboer, Thomas (2000), Gender and refugee status. Ashgate: Ashgate Publishing.

Todaro, Michael P. \& Lydia Maruszko (I987), 'Illegal migration and US immigration reform: A conceptual framework', Population and Development Review I3 (I) March: IoIII4.

Torpey, John (I998), 'Coming and going: On the state monopolizations of the legitimate "means of movement", Sociological Theory I6 (3): 239-259.

Torpey, John (2000), The invention of the passport: Surveillance, citizenship and the state. Cambridge: Cambridge University Press.

Triadafilopoulos, Triadafilos (2004), 'Building walls, bounding nations: Migration and exclusion in Canada and Germany, I870-I939', Journal of Historical Sociology I7 (4): $385-427$.

Truong, Thanh-Dam (2003), 'Gender, exploitative migration, and the sex industry: A European perspective', Gender, Technology and Development 7: 3I-52.

Uehling, Greta (2004), 'Irregular and illegal migration through Ukraine', International Migration 42 (3): 77-I09. 
Van de Pol, Lotte \& Erika Kuijpers (2005), 'Poor women's migration to the city: The attraction of Amsterdam health care and social assistance in early modern times', Journal of Urban History 32 (I): 44-6o.

Van der Leun, J.P. (2003), Looking for loopholes: Processes of incorporation of illegal immigrants in the Netherlands. Amsterdam: Amsterdam University Press.

Van der Leun, J.P. (2006), 'Excluding illegal migrants in the Netherlands: Between national policies and local implementation', West European Politics 29 (2): 310-328.

Van der Leun, J.P. \& R.C. Kloosterman (2006), 'Going underground: The labour market position of undocumented immigrants in the Netherlands', Tijdschrift voor Economische en Sociale Geografie/ Journal of Economic \&. Social Geography 97 (I): 59-68.

Van der Linden, Marcel (I988), 'The national integration of European working classes (I87I-I9I4): Exploring the causal configuration', International Review of Social History 33: 285-3II.

Van Eijl, Corrie (2005), Al te goed is buurmans gek: Het Nederlandse vreemdelingenbeleid 1840-1940. Amsterdam: Aksant.

Van Leeuwen, Marco (I992), Bijstand in Amsterdam, ca 1800-1850: Armenzorg als beheersings- en overlevingsstrategie. Zwolle/Amsterdam: Waanders.

Williamson, Jeffrey G. \& Kevin H. O'Rourke (2002), 'When did globalisation begin?', European Review of Economic History 6: 23-50.

Wong, W. H. \& B. Tong (2005), American paper son: A Chinese immigrant in the Midwest. Urbana/Chicago, Illinois University Press.

Zeidel, Robert F. (2004), Immigrants, progressives, and exclusion politics: The Dillingham Commission, 1900-1927. DeKalb: Northern Illinois University Press.

Zolberg, A. (I990), 'Reforming the back door: The Immigration Reform and Control Act of I986 in historical perspective', in V. Yans-McLaughlin (ed.), Immigration reconsidered: History, sociology, and politics, 315-339. New York: Oxford University Press.

Zolberg, Aristide (2006), A nation by design: Immigration policy in the fashioning of America. New York: Harvard University Press. 



\title{
2 Tracing back 'illegal aliens' in the Netherlands, 1850-1940
}

\author{
Corrie van Eijl
}

Regulation of migration is not a recent phenomenon in the Netherlands. The conditions for the entry and deportation of aliens were laid down in the first Dutch Aliens Act of I849. Although illegality is strongly related to this kind of lawmaking, with its mechanism of inclusion and exclusion, the Aliens Act did not result in a clear distinction between legal and illegal immigration. Many aliens were 'unwanted' and they were deported, but it took almost a century before the term 'illegal' entered the policy documents and public debates on migration. The main aim of this chapter is to trace and explain this process of 'illegalisation'.

Migrant illegality has been a topic in migration studies for some time, first in the US but recently also in Europe. Thanks to this research, we are better informed about illegal migration, although most studies concentrate on immigration policy in the last decades and pay very little attention to historical developments (De Genova 2002).

The term 'illegal migrants' has been criticised in migration studies and has been replaced by other terms when it became more and more politically charged (Koser 2005; see also the introduction to this volume). Despite the objections of many researchers - and immigrants the term 'illegal' will be used in this chapter. Apart from problems with alternative terms, it is appropriate to use the term 'illegal' here since our aim is to trace the history of the concept 'illegal alien'. Furthermore, as Mae Ngai does in her work on the history of illegal immigration in America, I use the term 'alien' to indicate someone who is not a citizen (Ngai 2004).

Aliens have been deported from the Netherlands for a long time. These migrants were referred to as unwanted or undesirable. It was only after a certain point in time that specific groups of aliens were considered 'illegal'. This change of terms is important since it is indicative of changes in the relations between aliens and the state. Migrant illegality is not a fixed category, but it is the result of changes in legal regulations and is connected to processes of differentiation and exclusion. The construction of migrant illegality is related to increasing state intervention, lawmaking and border control. It is also related to in- 
creasing inequality between citizens and non-citizens and more strict immigration regulations protecting access to residence and citizenship.

Immigration laws, which formulate restrictions on the entry and stay of aliens in the country, define what is legal and consequently generate an area of illegal practices. Recent studies indicate that these processes of categorisation and 'illegalisation' were not the same for men and women. Citizenship is a gendered concept. In many countries and for a long period of time women have been at best provisional citizens who lost rights when they married and were deprived of their nationality when they married a foreigner. Regulations on the entry and residence of immigrants sometimes distinguished between men and women as well. Even when migration regulations and laws on citizenship seem to be gender-neutral, they have often been applied differently to men and women (Bredbenner I998; De Hart 2003; Van Eijl 2005; Moloney 2006). In tracing the history of the concept of migrant illegality, in which citizenship and immigration regulations are important aspects, a gender perspective is essential.

Initially, immigration laws such as the Dutch Aliens Act of I849 were short and uncomplicated, and did not differentiate between aliens in a detailed way. When these laws evolved into increasingly more complicated pieces of legislation, differentiation increased and various categories of aliens were constructed, such as refugees, labour migrants and immigrants who entered the country for family reunification.

When tracing the history of immigration policy and exclusion in the United States, Ngai (2004) has demonstrated how the construction of migrant illegality in the US was firmly based on racial difference. The ban on the immigration of Chinese labourers imposed in I882 and the special programmes for Mexican migrants generated large-scale illegal migration from both these countries. In the US, Chinese and especially Mexican immigrants became the embodiments of the 'illegal alien'.

In other countries immigration laws also differentiated between various categories of aliens, which resulted in specific forms of exclusion and the 'illegalisation' of more and more aliens. In the German empire, for instance, specific rules were laid down for Polish migrants in the decades before the First World War in order to to prevent the 'Polonisation' of the eastern part of Prussia (Bade I984). Poles were only allowed to work in the agricultural sector in the eastern part of Germany, and a rotation system forced them to leave the country each year for seven weeks. Although they were not labelled as 'illegal', the anti-Polish measures reduced the Poles to second-class immigrants.

In a recent study on immigration control Rosenberg (2006) tells how the Paris police took over the immigration service in the I920s and how they made distinctions between people according to citizenship and national origin. By means of intensive police surveillance 
such as door-to-door checks, periodic raids and the creation of millions of files with detailed information on the whereabouts of the foreign born, the police controlled immigrants' lives and most of all the lives of colonial subjects. Rosenberg's work shows the importantance of gaining insight into the categorisation and exclusion of immigrants via both policymaking and the implementation of these rules.

Migrant illegality is closely related to 'deportability', as De Genova (2002) has argued. Many 'illegal' migrants may never be deported, but the threat of deportation determines their status. This does not necessarily mean that the deportation of aliens was always a matter of illegality. No single state was keen on aliens who were likely to become a public charge (see also Moloney 2006), and in many countries they were either not admitted or were deported as soon as they began begging or became penniless. States were responsible for their own subjects and were expected to take them back when other countries turned them away. Such forced removals were also possible within states. In nineteenth-century England, the Poor Law enabled the authorities to send poor people back to the town responsible for their maintenance. This was also done with Irish migrants, although they were British subjects. Between I824 and I83I more than 50,000 poor Irishmen were sent back to Ireland (Feldman 2003: 5I). Nevertheless, these deportations or forced removals of migrants were not a matter of illegality. It is not useful to stretch the concept of 'illegal alien' to such an extent that all poor and deported aliens are included. It must be noted that they were not deported because they lacked the necessary permission to enter or stay in the country, but rather because they could not support themselves. The migrants concerned were not entitled to relief in the town or state where they lived, and a job or another source of income would have prevented their deportation.

The distinctive characteristic of 'illegality' is that the status of aliens is defined by laws that lay down the rules for entry and stay. Aliens who lack a legal status due to the way they entered or are staying in the country depend on the authorities to change their status. Many recent 'illegal' migrants do actually succeed in supporting themselves, which often enables them to stay in the country for a considerable time. Nevertheless, their illegal position and the threat of detection and deportation make them vulnerable (Van der Leun 2003). The power of the state to define the legal status of aliens in the country is the decisive factor in the construction of 'illegal aliens'. The construction of immigrant illegality is a long-term process that is generated by immigration regulations. These regulations are of course influenced by various factors such as political and economic developments, public debates on immigration and border control. It is precisely this process of deliber- 
ate intervention, differentiation and exclusion that is interesting when trying to understand illegality (see also De Genova 2002).

Although deportations are not in itself indicative of illegality, the history of deportation policy and the implementation of these rules can reveal when and how inequality between citizens and aliens, and between various categories of aliens, emerged or increased, and how these processes of exclusion took shape.

In this chapter I look at the construction of immigrant illegality in the Netherlands in the period between the introduction of the first Alien Law (I849) and the outbreak of the Second World War. To trace this history of debates, lawmaking and implementation, I have looked closely at legal regulations, the archives of the Department of Justice, parliamentary proceedings, police records and publications. The main purpose is not to determine whether or not illegal aliens were present in the Netherlands before I940, but to trace the construction of illegality in legal regulations and in its implementation.

Many studies on migrant illegality distinguish between illegal entry, stay and work (see for example Düvell 2006). Aliens who enter the country legally can become 'illegal residents' by overstaying their visa, for instance, or working without the necessary permits, thus becoming illegal labourers. Sometimes other domains are taken into account as well, such as the use of social security or housing facilities by immigrants without a residence permit. When tracing the history of illegality in the Netherlands I will concentrate on entry and stay. Unlike nationals, aliens can be confronted with the charge of illegal entry and stay, and it is their illegal stay that makes them 'deportable'. Illegal work by immigrants was not a major issue in the Netherlands between I850 and I940, but there were some special regulations for immigrant workers that will be discussed below. Other activities that are against the law, such as engaging in illegal trade or making use of illegal housing, are activities in which citizens are more frequently involved than aliens. For this reason they are left out of the analysis.

The chapter starts with an overview of immigration regulations between I850 and I940. When and how did illegality appear in the aliens legislation and when did illegal immigration enter the migration debate? To what extent was the construction of illegality in the Netherlands gendered? Did borders create different barriers for male and female immigrants? In the next section I will trace the processes of differentiation and categorisation of aliens in the implementation of these rules and have a closer look at deportation practices since I850. Jewish refugees are the subject of the last part of the chapter. When they entered the country in the I930s, strict regulations were issued to prevent their arrival and the terms 'illegal refugees' and 'illegal entry' entered the political debate. 


\subsection{Entry regulations in the Netherlands}

Regulations restricting the entry or stay of aliens have long been in effect in the Netherlands. Initially these were local regulations - until the Aliens Act was passed in I849, laying down the conditions for the entry and deportation of aliens on the national level. This might suggest that the concept of 'illegal immigration' dates back to this period, but in reality the situation was more complex, as we shall see.

The main purpose of the Dutch I849 Aliens Act was to prevent the entrance and stay of poor aliens who were liable to become a public charge (Van Eijl 2005). According to this act, all aliens with means of subsistence and a valid passport (at that time: a passport with a visa) had the right to enter the country. They received a permit to stay in the Netherlands, which was valid for three months and could be extended repeatedly. During the period of validity of this residence permit they could not be expelled from the country, even if they lost their means of subsistence. Those who did not meet the requirements for a residence permit could enter the country as well. However, without this permit the police could easily deport them if it was found that they could not support themselves or if they posed a risk to public order.

Aliens without a residence permit were not officially admitted, but that did not mean that they were illegal. It was not illegal to enter the country without identity cards or money, nor was it illegal to return after deportation. Almost anybody could cross the Dutch border without any difficulty. In fact throughout the nineteenth century the border control was too primitive to stop even the most undesirable aliens, such as gypsies. Once inside the country, aliens did not have to ask for a permit to stay in the Netherlands. In I849 the Minister of Justice ordered the local authorities to register all aliens staying in their community, but aliens themselves were not obliged to report to the police.

Although there was no reference to 'illegal' immigration, the Aliens Act did distinguish between aliens who were admitted and those who were not. A strict enforcement of the law could have resulted in a more rigid distinction between these two groups, and as a result the second group could have been labelled 'illegal aliens'. In practice the opposite happened. The enforcement of the Aliens Act eased up soon after it was issued due to vague statements and an arbitrary administration. At the same the time as the bill was passed, the Minister of Justice issued his first instructions on the administration of the Aliens Act. He urged caution and stressed that the act was not meant to restrict the entry of 'hard-working men' (no mention was made of hard-working women). Hard-working men should be allowed to enter the country to look for employment. However, the police should not give residence permits to migrants without steady jobs and income. The Minister feared that the 
foreign poor would receive residence permits and that it would not be possible to deport them if they were found to be penniless or begging.

Since at least seven similar orders were issued in the months after the introduction of the law and still more in the next two years, the enforcement of the Aliens Act slackened. The issue of residence permits gradually disappeared, although practices were not the same throughout the country. In The Hague and Rotterdam the police issued only a few hundred permits each year and stopped doing so altogether in the I870s, while Amsterdam issued many more residence permits (900I500 yearly) and continued this practice until the beginning of the twentieth century (Pöckling \& Schrover 2002; Van Eijl 2005). Nevertheless, the number of permits gradually decreased in Amsterdam as well and more and more foreign residents did not have official residence permits. The disappearance of the permits blurred the distinction between those who were officially admitted and those who had no such legal approval. Consequently, the I849 Aliens Act lost most of its effectiveness in practice, but it was not officially abolished.

After the First World War new regulations were issued. The large numbers of foreign soldiers and refugees in the country, and fear of the arrival of communist agitators, caused the government to tighten the control of aliens. All foreigners were obliged to report to the local police within 24 hours of their arrival, and all foreign residents in each municipality were registered. After a few years - when peace had returned - these regulations were repealed, and starting in 1922 aliens were no longer required to report to the police or to be registered. Yet, especially in larger cities, the local police often continued this practice of alien registration (Lucassen \& Vermeulen I999).

Despite these new regulations and practices, the I849 Aliens Act was still valid and remained in force until I967 when a new Aliens Act replaced it. This meant that the entry and exit (deportation) of aliens continued to be regulated according to the 1849 act, which did very little to limit the freedom of movement of foreign residents and gave little indication of further categorisation and 'illegalisation'. However, not everyone was treated in accordance with that law and for some groups special rules were laid down. The research by Lucassen (I990) on Dutch policy with respect to gypsies makes this clear. Although gypsies were only a small minority of all the foreigners entering the country, the Minister of Justice frequently issued secret instructions on how to deal with these bear tamers, coppersmiths and other 'gypsies'. From the end of the I880s onwards, mayors of towns and chiefs of police received orders not to grant permits to gypsies who wanted to put on a show or to set up camp. If they were found at the border they were frequently sent back (mostly to Belgium), even if they proved to have means of subsistence. Gypsies were considered to be unwanted aliens: 
their itinerant way of life aroused suspicion and they were associated with petty theft, fraud and begging (especially by women and children). The special orders concerning gypsies were also the result of the regulations being passed in neighbouring countries where these itinerant groups were increasingly excluded.

Other migrants who received special treatment were Chinese immigrants. They were mainly sailors and ex-sailors who lived in concentrated areas in the port cities of Amsterdam and Rotterdam. Their numbers increased in the I920s because there was little employment in the shipping trade and few succeeded in signing on as a sailor. Since this group often gambled or violated the opium law, but also out of the Dutch's own ignorance of Chinese language and culture, the police watched them more closely than other immigrants and kept a separate 'Chinese registration'. They could not be deported, however, because deportation would involve considerable costs and long negotiations with China.

Although they were considered unwanted, gypsies and Chinese immigrants were not characterised as illegal in the Netherlands. Apart from the deportation of some 225 Chinese immigrants in 1922 after disturbances in Amsterdam, they were mostly left in peace (Van Eijl 2005). The measures taken with regard to gypsies were often temporary and were frequently ignored by local authorities, but gypsies were increasingly categorised as a specific group and treated accordingly. The most far-reaching policy, however, was not aimed at gypsies or Chinese immigrants but was formulated upon the arrival of Jewish refugees, and in I938 we come across references to 'illegal entry'. However, a closer look at the sizable group of aliens who were deported after 1850 shows that the processes of differentiation and categorisation of aliens had started much earlier.

\subsection{Not illegal but unwanted: Deportations after 1850}

Traces of 'illegalisation' are not only to be found at the level of legislation, but also at the level of implementation of the regulations. There have always been aliens in the country whose stay was not or no longer desirable. One might even argue that all the people who were deported from the Netherlands were more or less illegal aliens, since they did not meet the requirements laid down in the law. Yet the term 'illegal' was never used to describe them or their position and, although they were finally expelled from the country, neither their entry nor their stay was seen as illegal. It is worthwhile to take a closer look at the deportation practices: who was liable to deportation by the police? 
The I849 act was mainly aimed at reducing the number of alien poor, and it therefore enabled an easy and rapid deportation of all those who were not able to earn their living. This would not only reduce begging and vagrancy, but would also lessen the demand on the government's poor relief coffers. It is hardly surprising that the overwhelming majority of the aliens were expelled because they lacked means of subsistence.

In order to find out who was deported I made use of the Algemeen Politieblad, the official weekly journal of the police, which first appeared in I852. The journal provides a description of all deported aliens and includes name, age, occupation, place of birth and residence and at least in the first decades - reason for expulsion. Most of these descriptions of deportations refer to one person, but an entry could also refer to a couple, a family or sometimes a whole group. In I9Io, for instance, nine entries on the deportation of several gypsy families comprised 44 persons: nine couples, two sisters, one adult son and 23 children aged between one and seventeen years. These multiple registration under one heading indicate that the number of expelled aliens was higher than the number of entries in the journal. Furthermore, comparison with other sources shows that not every deportation was reported in the journal. ${ }^{\mathrm{I}}$

According to the Algemeen Politieblad, an average of 2,500 people were deported yearly between 1852 and I940. For further analysis of the deportation practice, a sample was drawn for the years 1870 , I900 and I930. Since many more men than women were deported, the sample included all deported women and ro per cent of all deported men registered in the Algemeen Politieblad (Van Eijl 2005). This sample forms the basis of the following analysis.

The numbers of deportations fluctuated between I,000 and 3,500 yearly, with an exceptional peak of 5,500 in 1930. Almost all of these aliens were deported because they had no means of subsistence; some were found wandering and begging. The majority came from a neighbouring state, which reflects the overall pattern of migration to the Netherlands. In I870, I900 and I930 Germany and Belgium were the countries of origin of 60 to 83 per cent of the deported men and 73 to 88 per cent of the deported women.

From the Algemeen Politieblad it is clear that the Aliens Act, which did not discriminate according to gender, was not applied equally to men and women. Between I850 and I940, roughly 85 to 90 per cent of all the deportees were men, mostly single. During most of this period only ro per cent of all deportations involved women, a percentage which rose to 20 or 25 per cent in the I930s. This rise is probably the result of the many German women who had come to the Netherlands 
to work as domestic servants, some of whom did not succeed in finding a job during the economic depression in the I930s.

These figures show that men ran a much higher risk of deportation than women. However, to estimate the risks, these figures should be related to the total numbers of men and women who passed the Dutch border in these years, and these are not available. The only thing we do know is the sex ratio among the aliens in the ten-year censuses. According to the censuses, the number of foreign men was initially somewhat higher than the number of foreign women in the Netherlands, but after I900 their numbers did not differ much, while in the I930s the number of foreign women was much higher. The problem is that the census only registers resident foreigners, not those who travel around and leave after a short period of time. This latter group possibly included more men than women. Still, it's unlikely that the sex ratio of the deportees corresponds to that of all men and women entering the country. It seems safe to conclude that alien men did indeed run a much higher risk of deportation than alien women.

This high proportion of male deportees is probably characteristic of other aliens policies besides that of the Netherlands, but there are few studies from those contexts to provide us with comparable details. Reinecke surprisingly mentions the same ratio (Io per cent female deportees) for the German Reich between I89o and I9I4 (see Reinecke's chapter in this volume). However, this figure only refers to those who were forced to leave the country as a consequence of their being convicted by court order (with some 500 records yearly). In this case a much higher proportion of men is to be expected since in general men were brought before court much more often than women. It is unclear whether the ratio was the same amongst the much larger group of people who were deported by the police, not because they violated the law but because they lacked means of subsistence.

It is difficult to account for the high percentage of male deportees in the Netherlands. Probably the opportunities for employment were better for women, who could rather easily find jobs in domestic service and the catering industry. Perhaps women were also more certain of their employment before they migrated. Another possibility is that women tended to return of their own volition if they were without employment or money, whereas men were more often expelled by the police. And of course the police may have concentrated their surveillance on foreign men because they considered them to be more inclined to theft and other criminal activities than women. It was probably a combination of all these reasons that accounted for the high rate of male deportees.

The number of women deported was smaller than the number of men, and the grounds for expulsion were also different. The most 
striking example is the deportation of women because of their 'moral behaviour', which means their deviant sexual behaviour. Foreign men were judged and deported on moral grounds as well, but in these cases it had to do with poverty, crime or illegal ways of making a living, such as running a gambling joint. Men were never expelled because of their sexual behaviour. The only case in which alien men were associated with sexual morality had to do with a small number of Chinese men who were suspected of selling condoms in the I930s. They were monitored by the police but not deported, since the costs of deportation to China would have been too high (Mak 2000: I4O-I42).

The treatment of foreign prostitutes illustrates the gendered nature of the aliens policy during the earlier period. The I849 Aliens Act required that aliens be able to support themselves, but there was no reference to moral or immoral ways of making a living. Prostitution was not illegal and many foreign women worked as prostitutes in Dutch cities. The liberal attitude towards prostitution changed in the last part of the nineteenth century, when brothels in several cities were closed. From I9II onwards, when the law on public morals came into force and prostitution was forbidden, there were grounds to deport foreign prostitutes. Nevertheless, many foreign prostitutes were deported before I9II, even if they earned more money than many other foreign women (or men) did. Between 1890 and 1900 - in a period with a great deal of debate on public morals - prostitution was the most common reason for the deportation of women. In I895 half of the 257 deported women were prostitutes or were suspected of being prostitutes (Van Eijl 2005: 227).

The gendered nature of the deportation policy in the Netherlands was not unparalleled. Moloney (2006) analysed the US deportation policy in the late nineteenth and early twentieth centuries and came across similar cases. She shows that the 'moral turpitude' clause in US immigration law was often inconsistently applied and intertwined with ideas about women's economic role. Although few women were actually deported on these grounds, Moloney concludes that efforts to exclude or deport immigrants based on concerns over sexual morality had more profound effects on women. In Germany, gendered deportation policy and practices existed as well. According to Reinecke (in this volume), immigrant women were more likely to be deported because of suspected indecent behaviour.

The surveillance and control of sexual behaviour by the aliens police was not restricted to prostitutes. The police (and others) also interfered in the moral behaviour of foreign women who earned their living in other occupations, such as domestic service. In the interwar period, German domestic servants formed one of the largest groups of migrants in the Netherlands. There were considerable concerns about the 
'moral' (sexual) behaviour of these girls and young women, which was, on the one hand, visible in regulations to keep them out of harm's way, most of all to protect them from 'white slave traders' and other hidden dangers. On the other hand, their sexual behaviour was easily called into question. It is not difficult to find references in the press and in police reports to domestics, many of them German, who were accused of having affairs with married men or living an indecent life (Henkes I995: I22-I24). This tendency to interfere with the private lives of German domestics differed widely from town to town, and not all local police officers were as harsh as the head of the aliens police in The Hague was, for instance. Besides, as Lucassen (2002) rightly points out, not many German domestic servants were actually deported because of indecent behaviour. Nevertheless, the effect of this monitoring should not be underestimated. The aliens police kept records on domestic servants and monitored their behaviour. Simply the knowledge that a foreign domestic could be deported if she did not behave well meant that she was vulnerable to gossip and threats by employers or others to inform the police. Henkes (I995: 123), who interviewed German domestics, found that many women experienced this risk of deportation as a very real threat.

Opinions on the correct sexual behaviour of women influenced the deportation policy in the Netherlands. In the nineteenth century many prostitutes were deported on these grounds, and in the interwar period domestics frequently felt threatened because of their 'deportability'. Yet even the foreign prostitutes who were deported because of their sexual morality and illegal trade (after I9II) were not referred to as 'illegal' aliens. This term only entered the debates after the arrival of Jewish refugees in the I930s.

\subsection{Jewish refugees: The first 'illegal' aliens}

From I933 onwards, and especially after 1938 when persecution in Germany intensified, Jewish refugees fled the country, and 40,000 Jewish refugees crossed the German-Dutch border between I933 and 1940. Most of them came from Germany; others were so-called 'East Jews' who had migrated to Germany from Poland or Russia. As in most other countries, such as Belgium and France, new rules were drafted to prevent their entry. These rules only applied to 'refugees' or, in other words, to 'those who were forced to flee from their country by local circumstances'. ${ }^{2}$ Since Jews were persecuted in Germany, all Jews who entered the Netherlands were assumed to be refugees, whether or not they wanted to be labelled as such. In May I938 the government decided that 'refugees' (by which they meant Jews) could no longer en- 
ter the country, even if they had passports, employment and money. The fact that these new rules were not in accordance with the Aliens Act was tacitly ignored. The German-Dutch immigration treaty of I904, which stated that all German citizens who did not pose a risk to public order and who could provide for themselves had to be admitted to the Netherlands, was ignored as well. Remarkably, very little attention was paid to these violations of the law.

In May I938, crossing the Dutch border became an illegal activity for refugees. Initially policymakers did not focus on the distinction between legal and illegal immigrants, but on the distinction between aliens (which referred to immigrant workers) and refugees. Aliens were treated according to the Aliens Act and to the law regulating the employment of foreigners. Refugees, on the other hand, were seen as a specific group of aliens who were subject to special directives. Today refugees also constitute a specific group. The Refugee Convention of I95I gives them the right to apply for asylum, and they can enter the country if the border is closed to immigrant workers. Jewish refugees, however, were put into a category not with more rights - as is true of refugees today - but with fewer rights and fewer chances than 'regular' (non-Jewish) aliens in the I930s (Van Eijl 2005: 196-I99).

After the Kristallnacht in November 1938 many Jewish refugees entered the Netherlands despite restrictions and border controls. Documents in the archives of the Department of Justice reveal that at this time, with a rising number of Jewish refugees, the term 'illegal' was used by policymakers and police officers. Tenkink, a high civil servant in the department, repeatedly wrote about 'illegal refugees' in his letter of I4 December I938 to the Minister of Justice, referring to the Jewish refugees who had recently entered the country (Berghuis I990: 44-46). The next day the Minister ordered that 'every refugee who has entered the country illegally after io November shall be brought to a special camp'. Those who could be associated with 'illegal border-crossings' after I7 December I938 were liable to deportation to Germany. ${ }^{3}$

From that moment on, terms like 'illegal refugees' and 'illegal entry' were used frequently by ministers, civil servants, police officers, journalists and others, always with reference to Jewish refugees (Van Eijl 2005). This did not happen only in the Netherlands. The term 'illegal' was also being used in other countries at this time, probably as a result of entry restrictions and international debates on the 'Jewish refugee crisis' (Caron I999; London 2000). However, most studies on Jewish refugees do not explicitly refer to the use of these terms in debates and letters. When the studies refer to 'illegal refugees', that may not be the term used by contemporary policymakers; it may be the author who uses this term to indicate a group that was referred to as 'irregular', 'unwanted' or 'undesired'. ${ }^{4}$ 
The severe entry restrictions and border controls ordered by the Minister of Justice in 1938 were of major importance in the process of differentiation and the construction of Jewish refugees as a specific group of aliens. Not only was their flight labelled an illegal activity, but Jewish refugees in the country - whether 'legally' present or not - were also seen as being prone to other illegal activities including illegal employment.

Although entry was restricted for both male and female refugees, Jewish men and women were not treated equally. In general, policymakers and policemen showed more consideration for female refugees. In his order to deport 'illegal' Jewish refugees, the Minister, for one, was willing to make an exception if the deportation would be very harsh and involved 'single women and children'. Men who crossed the border illegally were sent to one of the special camps for 'illegal' refugees. Women and children who entered the country illegally were accommodated in private houses outside these camps. ${ }^{5}$ In addition, the official ban on employment for refugees was less strictly enforced for women. Male Jewish refugees rarely succeeded in getting work permits, while female refugees were sometimes allowed to work as domestic servants because of the shortages in this profession. Small groups of female refugees even received permits to enter the country to work as domestics (Van Eijl 2005: 20I).

In the Netherlands, Jewish refugees were the first group of aliens who were referred to as 'illegal' in public discourse, government documents and ministerial orders. This was the result of specific regulations that categorised Jewish refugees as unwanted aliens who had to be refused at the border. All those who still managed to get through entered 'illegally' and were threatened with deportation.

\subsection{Conclusion}

The I849 Aliens Act could have been the starting point of the process of 'illegalisation' in the Netherlands, but due to a lack of implementation the law did not result in a clear distinction between legal and illegal aliens. Rather the opposite happened: entry regulations were hardly ever applied and after some decades only a few aliens still received official residence permits. Although certain categories of aliens were considered unwanted, there was no concept of 'illegal' immigration for a long period after 1849 .

Still, processes of exclusion were evident in the nineteenth century aliens policy. Not all aliens were treated equally and their treatment was not always in accordance with the Aliens Act. The special policy on gypsies that went into effect at the end of the r88os is an early ex- 
ample of differentiation and exclusion. However, at this stage the policy was too fragmented, the implementation too defective and the group too small to lead to 'illegalisation'. This observation indicates that the concept of migrant illegality did not simply arise as the result of stricter immigration regulations, but that it also depended on the opportunities and willingness to enforce these laws. The use of the term 'illegal' in relation to immigration dates from the end of the I930s. In 1938, the entry restrictions for Jewish refugees were so severe that in effect they constituted a closing of the border. The refugees who ignored the ban and entered the country had the dubious honour of being the first 'illegal aliens' in the Netherlands.

Before the I930s there was no concept of immigrant illegality. When the term 'illegal' appeared towards the end of the I930s it was restricted to entry and stay. Illegal work by immigrants was not a major issue in the Netherlands before I945 (and even before the I970s). Apart from a very short period in the beginning of the I920s and in the years after 1934, when immigrant labour was bound by regulations, aliens were free to work wherever they wanted. When migrants worked without a permit at the end of the I930s, it was not the alien worker but the employer who broke the law. Working without a permit did not make them 'illegal aliens', nor did it make them 'deportable'.

The categorisation and exclusion of immigrants existed long before the I930s, mainly in the form of a deportation policy. Throughout the period of I849-I940, poverty was the main reason for deportation. Alien men ran a much higher risk of being deported than alien women, either because they were more often without means of subsistence or because the police targeted alien men more than women. Policymakers and the police had more compassion for women, something that was also apparent in the policy regarding Jewish refugees. Another important conclusion is that women were deported on different grounds than men. Many foreign prostitutes and some foreign domestic servants were expelled because they were suspected of indecent sexual behaviour. There were no controls placed on the sexual behaviour of foreign men, nor was this considered a reason to deport them.

This policy on control and deportation illustrates a connection between the sexual behaviour of women and legal stay. Few studies have concentrated on illegal migration in the period between 1945 and the end of the I970s, and there is no indication of any further development of a gendered concept of migrant illegality. Studies on migrant women in recent decades often concentrate on trafficking and prostitution, which suggests that illegality is still (or once again) strongly related to female sexual behaviour (see also the introduction to this volume). More research is necessary to find out when and how this connection between sexual behaviour and migrant illegality reappeared in 
the post-I945 period, both in migration policy and in public and scholarly debate.

Although differentiation and exclusion had been apparent in Dutch aliens policy since the late nineteenth century, the terms 'illegal entry' and 'illegal stay' did not enter the debate until 1938. This change of terms - from unwanted or undesirable to illegal - is not just a matter of changing fashion, but signifies real changes, both in immigration policy and in the conceptualisation of aliens. The use of the term 'illegal aliens' indicates increasing differentiation between citizens and aliens and between various groups of aliens. This discrimination is based on an immigration policy that is highly exclusive: rigid legal regulations for entry and stay (at least for specific groups), a strict enforcement of the laws and the threat of deportation for those who ignore the rules. Several developments fostered this process of illegalisation. Since the nineteenth century, state interference and state control had increased considerably. It became even stronger after the First World War. An important example is the interference with unemployment benefits and the labour market. A process of centralisation and a rapid growth of the bureaucratic system accompanied the process of state formation. The administrative machinery and the growth of the local aliens police enabled much more control of the entry and residence of aliens.

But changes in the role of the state and in legal restrictions were not the only decisive factors in the process of illegalisation. This example of the Netherlands illustrates that 'illegal' aliens only appeared when there was concern about too many foreigners entering the country and when further immigration was considered undesirable. The economic depression had resulted in high unemployment, which was still high when the Jewish refugees started coming to the Netherlands, and there was considerable pressure in the I930s to restrict immigrant labour. Although the 'illegalisation' of Jews was not the immediate result of the economic depression and high unemployment, processes of categorisation and exclusion of immigrants intensified during these periods (cf. Rosenberg 2006). Another indication of this connection is the process of illegalisation during the post-war period, which stagnated in the first decades that were characterised by labour shortages while it accelerated after the oil crisis and increasing unemployment in the I970s.

Immigration regulations and control have always concentrated on specific groups of aliens such as gypsies and Chinese immigrants. It is hardly surprising that the concept of illegal immigration was not shaped in relation to immigrant workers but in relation to Jewish refugees. Unlike other groups who had migrated to the Netherlands, such as the 'other', non-Jewish Germans and Belgians, the ethnicity and cul- 
ture of the Jewish refugees, and especially of the 'East Jews', were perceived to be very different from that of the Dutch (Van Eijl 2005). In this respect there is a similarity with the much smaller groups of gypsies and Chinese immigrants, who were also portrayed as exotic people with aberrant behaviour and odd habits. Although anti-Semitism certainly existed in the pre-war period in the Netherlands, the illegalisation of Jews was connected to a more general aversion to immigrants with aberrant looks and aberrant behaviour. The threat these ethnic groups represented to policymakers was not only based on their supposed aberrant behaviour, but also, or mainly, on the fact that they could not be deported. They were stateless or belonged to states that would not take them back. The lack of bilateral treaties or diplomatic relations (and large distances) hindered their deportation. Since the aliens office and the aliens police would be stuck with them once they were inside the country, these institutions were keen to prevent their entry. Accordingly, it was not only ethnicity or anti-Semitism that contributed to the construction of illegality of Jewish refugees, but also the fact that they were not deportable.

The distinction between legal and illegal immigration that entered the debates in the I930s would not disappear thereafter, although during some periods there was more discussion and more policy formulated to fight illegality than in other periods. Since the economic depression in the I970s, and especially since the considerable increase in the number of asylum seekers in the late I980s, concern about the illegal stay of refugees and migrant workers has increased. The process of illegalisation during this period is usually related to the welfare states. Exclusionary policies should prevent too many immigrants from making use of welfare provisions that have been planned as a system of mutual solidarity. Yet there is little research on the construction of illegality in the post-I945 period, and it is not clear if and how illegalisation is related to the development of the welfare state. Recent studies on illegal immigration in the Netherlands that deal with this period (Engbersen, Van der Leun, Staring \& Kehla I999; Staring 200I; Van der Leun 2003) are mostly concerned with the dimensions of illegal immigration, mechanisms of survival and incorporation of illegal immigrants, and pay less attention to the concept of illegality. The findings in this chapter on the pre-war period indicate that the emergence of illegality was connected to the development of the state, but also to gender, ethnicity and deportability. Further research will be necessary to see if these mechanisms still played a role in the construction of migrant illegality in the post 1945 decades. 


\section{Notes}

I Especially in the first half of the I920s, many more Germans were deported than the number recorded in the Algemeeen Politieblad suggests (see Van Eijl 2005: 230).

2 Letter from the Minister of Justice to the Council of Ministers, I7 Marchi938 (National Archives, 2.06.00I, no. 5185).

3 Circular from the Minister of Justice, I5 December 1938 (Amsterdam Municipal Archives, 5225, inv. no. 4312).

4 This also applies to Rosenberg's study of Paris (2006). He frequently refers to 'illegal aliens' or 'illegal workers' in Paris in the I920s and I930s, but it is not clear whether those terms were used in contemporary sources. See also the papers from the conference 'Refugees from Nazi-Germany' in 2004 (Caestecker \& Moore, in press) and the discussion on $\mathrm{H}$-net on the use of term 'illegal immigration' in historical debates, papers and public discourse, started by Franck Düvell in March 2004 (http://h-net. msu.edu/cgi-bin/logbrowse.pl?trx=lm\&list=H-Migration).

5 Camp Westerbork, which was build in I939, was meant to accommodate both legal and illegal Jewish refugees (including single women and families), though the transfer of refugees had hardly started when the war broke out.

\section{References}

Bade, K. (I984), “"Preußengänger” und “Abwehrpolitik”: Ausländerbeschäftigung, Ausländerpolitik und Ausländerkontrolle auf dem Arbeitsmarkt in Preußen vor dem Ersten Weltkrieg', Archiv für Sozialgeschichte 24: 9I-I62.

Berghuis, C. (I990), Joodse Vluchtelingen in Nederland 1938-1940: Documenten betreffende toelating, uitleiding en kampopname. Kampen: Uitgeversmaatschappij J.H. Kok.

Bredbenner, Candice Lewis (I998), A nationality of her own: Women, marriage, and the law of citizenship. Berkeley: University of California Press.

Caron, V. (I999), Uneasy asylum: France and the Jewish refugee Crisis, 1933-1942. Stanford: Stanford University Press.

Caestecker, Frank \& Bob Moore (in press), Refugees from Nazi Germany and the liberal states in Europe. Oxford/New York: Berghahn Books.

De Genova, N.P. (2002), 'Migrant “illegality" and deportability in everyday life', Annual Review of Anthropology 3I: 4I9-447.

De Hart, B. (2003), Onbezonnen vrouwen: Gemengde relaties in het nationaliteitsrecht en het vreemdelingenrecht. Amsterdam: Aksant.

Düvell, Franck (2006), Illegal immigration in Europe: Beyond control? Houndsmill: Palgrave Macmillan.

Engbersen, G., J. van der Leun, R. Staring \& J. Kehla (I999), De ongekende stad 2: Inbedding en uitsluiting van illegale vreemdelingen. Amsterdam: Boom.

Feldman, D. (2003), 'Migrants, immigrants and welfare from the old poor law to the welfare state', Transactions of the Royal Historical Society 13: 79-I04.

Henkes, B. (I995), Heimat in Holland: Duitse dienstmeisjes, 1920-1950. Amsterdam: Babylon-De Geus.

Koser, K. (2005), 'Irregular migration, state security and human security'. Paper prepared for the policy analysis and research programme of the Global Commission on International Migration September 2005.

London, L. (2000), Whitehall and the Jews, 1933-1948: British immigration policy, Jewish refugees and the Holocaust. Cambridge: Cambridge University Press. 
Lucassen, L. (1990), En men noemde hen zigeuners: De geschiedenis van Kaldarasch, Ursari, Lowara en Sinti in Nederland, 1750-1945. Amsterdam/The Hague: Stichting Beheer IISG/ SDU uitgeverij.

Lucassen, L. (2002), 'Administrative into social control: The aliens police and foreign female servants in the Netherlands (I9I8-I940)', Social History 27: 327-342.

Lucassen, L. \& F. Vermeulen (I999), Immigranten en lokale arbeidsmarkt: Vreemdelingen in Den Haag, Leiden, Deventer en Alkmaar (1920-1940). CGM-working papers no. I, Amsterdam.

Mak, G. (2000), Sporen van verplaatsing: Honderd jaar nieuwkomers in Overijssel. Kampen: Stichting IJsselacademie.

Moloney, D.M. (2006), 'Women, sexual morality, and economic dependency in early U.S. deportation policy', Journal of Women's History I8: 95-I22.

Ngai, M.M. (2004), Impossible subjects: Illegal aliens and the making of modern America. Princeton/Oxford: Princeton University Press.

Pöckling, L. \& M. Schrover (2002), 'Registers van verstrekte en geweigerde reis- en verblijfpassen (I849-1923)', in M. Schrover (ed.), Bronnen betreffende de registratie van vreemdelingen in Nederland in de negentiende en twintigste eeuw, 35-68. The Hague: Instituut voor Nederlandse Geschiedenis.

Rosenberg, Clifford (2006), Policing Paris: The origins of modern immigration control between the wars. Ithaca/London: Cornell University Press.

Staring, R. (200I), Reizen onder regie: Het migratieproces van illegale Turken in Nederland. Amsterdam: Het Spinhuis.

Torpey, J. (2000), The invention of the passport: Surveillance, citizenship, and the state. Cambridge: Cambridge University Press.

Van der Leun, J. (2003), Looking for loopholes: Processes of incorporation of illegal immigrants in the Netherlands. Amsterdam: Amsterdam University Press.

Van Eijl, C. (2005), Al te goed is buurmans gek: Het Nederlandse vreemdelingenbeleid 18401940. Amsterdam: Aksant. 


\title{
3 Policing foreign men and women: Gendered patterns of expulsion and migration control in Germany, 1880-1914
}

\author{
Christiane Reinecke
}

I have problems supporting my mother and my child - and I have no relatives who can help me. Since I was born a Prussian citizen, I beg you to issue a residence permit to my husband. ${ }^{\mathrm{I}}$

Addressing her letter of 1882 to the Prussian Minister of the Interior, the Russian citizen Marie Gad was petitioning for the readmission of her husband to the country so he would be able to help her. The Russian-Pole Israel Meyer Gad, to whom she was married, had been forced to leave Germany after being expelled by local Prussian authorities. His wife, originally a Prussian citizen, was now struggling to support her family and was afraid of being deported herself.

Whether they were immigrants or former German citizens, foreign women living in late nineteenth-century Prussia found themselves in a vulnerable position. Every non-German citizen could be expelled from the German Reich. But according to their particular legal, economic and social status, foreign women and men were treated differently at German borders and on German territory. They were evicted for different reasons and encountered different problems in their confrontation with state regulations. Concentrating on the practice of expelling foreign citizens from Prussia and the German Reich, this chapter investigates these differences and how they emerged in the late nineteenth and early twentieth centuries.

States employed forms of immigration control in order to draw a line between welcome and unwelcome foreigners (Lucassen \& Lucassen I997; Böcker I998; Brochmann \& Hammar I999; Fahrmeir, Faron \& Weil 2003; Oltmer 2003). Administrative measures like border controls, work permits or expulsions helped to foster the distinction between 'us' (native citizens) and 'them' (foreign citizens). In response to diverse and often conflicting economic, social or national interests, they also erected hierarchies of exclusion that granted varying forms of access to different migrant groups. As a result, late nineteenth-century immigration policy was not only ethnically coded, but also classed and gender-specific. In the following, practices of exclusion will be investigated with a particular view to gender ethnicity and class. More specifically, the analysis focuses on the question of how gendered conceptualisations of citizenship, na- 
tionality and morality influenced the German politics of expulsion and the way in which foreign men and women were policed.

In late nineteenth-century expulsion policy, the exclusionary logic of migration controls and the legal framework of citizenship law were intertwined. Only foreign citizens could be expelled and had to be accepted back by their official country of origin, whilst native citizens could not be compelled to leave. Citizenship implied a protection against deportation from a state's territory (Fahrmeir I997, 2000). Therefore, the question of who belonged legally - the question of citizenship - became crucial in the context of expulsions. In the German Reich, women achieved citizenship either as children of their fathers or through marriage (Gosewinkel 2001: 294-303). But how this principle of dependent citizenship actually affected both men and women living in the Reich has barely been investigated. Even though scholars have begun to analyse the gendered nature of citizenship in other countries, most notably in the United States (Bredbenner I998; De Hart 2003; Gardner 2005), the situation in Germany has hardly been touched. What has been researched, however, is how notions of nationalism and racism influenced the definition of citizenship in nineteenth- and twentieth-century Germany. In his influential study on citizenship in Germany and France, Brubaker (1992) has argued that an ethno-cultural understanding of nationhood, which derived from the belated process of state-building in Germany, led to the imposition of the jus sanguinis as the leading principle of German citizenship law. According to Brubaker's teleological and at times overly contrastive narrative, the French state-centred conception of nationhood resulted in a broad definition of citizenship which permitted the automatic transformation of immigrants into citizens. Contrary to that, the German volkcentred understanding of citizenry required a law that was expansive toward ethno-cultural Germans and restrictive towards non-German immigrants. This ignores the fact that citizenship law treated women and men differently. And while Gosewinkel and others have shown that the historical process was indeed more complex and less coherent than suggested by Brubaker, they also merely allude to the gendered nature of German citizenship law (Gosewinkel 2001: 294-303; Trevisiol 2005: 20I-208). But as this chapter intends to show, German migration policy and citizenship law were hardly gender-neutral and should be understood rather with a view to the divergent legal, social and economic positions that foreign men and women occupied.

Nationalism was (and is) a gendered discourse. Women, whilst traditionally being excluded from political participation, often became implicated in nationalism as 'symbolic signifiers of national difference' (McClintock 1995: 355). They assumed the roles of the biological reproducers of a nation while also figuring as reproducers of the nation's 
boundaries; consequently, they had to be controlled in their sexual and marital behaviour (McClintock I995: 355). Scholars like McClintock (I995) and Stoler (I995) have shown that the regulation of sexual practices became a central instrument of power in the hands of a white middle class striving to guard the boundaries between itself and the 'degenerate classes' both in the metropolis and in the colonies. Based on these arguments, this chapter is concerned with the gendered policing of the nation's boundaries in citizenship law and migration politics.

Deportations were commonly employed by the German authorities in order to exclude unwelcome migrants. Moreover, the authorities used forced removal in order to penalise any non-compliance (like clandestine entry, unauthorised stay or illegal employment) with official regulations concerning mobility. As a result, the analysis of the actual practice of expulsion allows us to gain insight into the 'micro-mechanisms' of inclusion and exclusion, which characterised German policy at the time. To regularly expel those who were deemed to be 'undesired' was a central instrument employed by the Prussian state and the German Reich in order to regulate migration. It was one of a whole set of practices that had been established with the intention of controlling the entry, movement and lives of non-Germans on German territory. While deportations had originally been used to evict those who did not have the right to settlement in a municipality, they were now employed to exclude foreign citizens. However, the endeavours of the state to control the movements of foreigners, far-reaching as they were, did not go unchallenged by those subjected to them. Whilst some - like Marie Gad - attempted to question the orders with the help of letters and lawyers, others managed to remain clandestinely in the country or came back secretly. Migrants were agents in their own right who could challenge or circumvent exclusionary practices (Sciortino 2004). So in order to fully understand what impact the Prussian and German policies of expulsion had, these strategies will have to be taken into account.

In the federal German Reich, the various German Länder possessed far-reaching powers regarding the admittance, naturalisation or expulsion of immigrants. Foreigners thus could be expelled from the Reich or evicted from one of the German states. Depending on which authority ordered the removal, the evictions had different implications. When investigating the politics of expulsion in late nineteenthcentury Germany, these differences between the state level and the federal level should be taken into account. In the following, the interactions between state authorities and expellees are thus analysed on three levels: I. on the level of the Reich that expelled destitute foreigners and criminals; 2. on the level of Prussia that used deportations as 
a flexible instrument in order to regulate migration; 3. and finally with a view to the actual contacts between state officials and expellees. The first part deals with the practice of expelling and deporting foreign citizens from the German Reich. Analysing the reasons that were officially given in order to justify expulsions reveals the predominant need to expel criminals, paupers and prostitutes. Furthermore, it becomes clear that male and female migrants found themselves at the mercy of the state for different reasons. Concentrating on Prussia's official policy in the I880s and I89os, the second part refers to the nationalist underpinning of Prussian deportations and analyses the specific concern with mixed marriages in this context. While the antiPolish and anti-Semitic intentions driving Prussia's expulsions concerned men and women alike, the legal principle of dependent citizenship affected them differently when it came to their removal from the country. Using the petitions against expulsion orders as a source, these differences and the meanings that were attached to them will be analysed in the final part of this chapter.

\subsection{Forcing out the undesired: Expelling migrant men and women from the German Reich}

In the German Reich, foreigners did not have any legal right of residence. While a German citizen was entitled to live in the Reich, foreigners were merely tolerated (Isay I923: II5). Therefore they could be compelled to leave at any time. An expelled person was forbidden to stay in or move through the state's territory (Von Conta I904; Isay I923: I99-247). Hence, expulsions implied a formal spatial ban, and everybody who circumvented the order risked being interned or being deported again. Like border controls or passport regimes, the forced removal of foreigners underlined the territorial dimension of sovereign power. By aspiring to know about, identify and remove foreign citizens, modern states claimed to control the movement within their territories (Torpey 2000). In this context, the practice of removing foreigners was employed for a variety of exclusionary aims. In the Prussian and the German migration regime, it was primarily concerned with 'undesirable' migrants who were excluded because of their ethnicity, their socio-economic situation or their sexual morality.

In the federal German Reich, foreigners could be expelled either from the Reich or from the separate German states (from Prussia, Bavaria, Saxony, etc.). In both cases, the measures extended as far as the sovereign power of the expelling authorities went: foreigners expelled from Prussia were requested to leave Prussian territory; they did not necessarily leave the German Reich. In general, the expulsions from 
the Reich (Reichsverweisung) and from the various German Länder (Landesverweisung) involved different processes. The Reichsverweisung was based on criminal law and was laid down in a handful of paragraphs in the Criminal Code. ${ }^{2}$ Apart from advancing the exclusion of criminal foreigners, the measure focussed primarily on the removal of the foreign destitute and other likely public charges. A foreign citizen who was brought before a court and found guilty of a criminal offence (like theft, begging or 'vagabonding') could thus be handed over to state authorities, who in turn could rule on deporting the convict - instead of, or in addition to, sending him to a prison, workhouse or reformatory. In contrast, an expulsion from a German state like Prussia was an administrative measure that did not follow any juridical decision and implied a less formal procedure. It served officials as a flexible instrument, which allowed them to deport any foreign migrant deemed undesirable. Presumably because it did not require any juridical decision and was more flexible, foreigners were expelled more often from the German states than from the Reich. Whereas expulsions from the Reich were not very frequent, expulsions from Prussia were.

Before commenting on the Prussian policy, it seems worthwhile to have a look at the Reichsverweisungen first. Whereas it is difficult to establish the number of expulsions from the various German states, the details on deportations from the Reich were published regularly, including the name, occupation and offence committed by the deportees. According to these data, the overall number of foreigners expelled from the Reich was not very high: 586 foreigners were expelled in 1890 , 490 in 1900 and 514 in I9I0. ${ }^{3}$ The number of entries, however, was not equivalent to the number of people who had to leave the Reich. As men were considered to be the head of household, occasionally just their name was given, even though their whole family was forced to leave. Reflecting the prevailing views about women's dependency on male wage earners, some men were reported to be expelled 'with their wife' or 'with their family', while the names of their 'dependents' (wives and children) were not given. Hence, the overall number of female deportees is difficult to establish. However, according to the names and orders, which were published, it was men who were expelled in the majority of cases.

This does not reflect the demographic structure of the migrant population in the German Reich, as a high percentage of the migrant workers, especially in Prussian agriculture, were women. In 1907, 27.4 per cent of the foreign-born agricultural and industrial workers in the German Reich were female (Roller I994: 52f). In the same year, 4I.6 per cent of the foreign labourers in Prussian agriculture and 5.9 per cent of the foreign workers in Prussian industry were women (based 
on Bade I979: 503). According to the population censuses carried out every decade in December (which did not include the seasonal migrants who by then had left the country), women made up about 43 per cent of the foreign citizens in the Reich (Table 3.I).

Table 3.1 Foreign population in the German Reich according to the census ${ }^{4}$

\begin{tabular}{lllr}
\hline Year & Men & \multicolumn{1}{c}{ Women } & \multicolumn{1}{c}{ Total } \\
\hline 1890 & 244,086 & $189,168(43.66 \%)$ & 433,254 \\
1900 & 464,274 & $314,463(43.84 \%)$ & 778,737 \\
1910 & 716,994 & $542,879(43.05 \%)$ & $1,259,873$ \\
\hline
\end{tabular}

However, according to the lists of expulsions from the Reich, which were published annually, between 8.5 and I3.I per cent of the persons being ordered to leave were women (Figure 3.I). This percentage of female expellees remained stable throughout the German empire. Even if it is assumed that the actual number of women being forced to leave was higher (see above), it seems feasible that fewer foreign women than men were deported as a consequence of their conviction by a court. Apparently, this also was the case in other countries. In his analysis of the Dutch policy of expulsions in the interwar period, Lucassen (2002: 337) concludes that female immigrants 'were less likely to be expelled than men'. Similarly, Van Eijl observes that, between I850 and I940, the risk of being expelled from the Netherlands

Figure 3.1 Ratio of migrant men and women expelled from the Reich

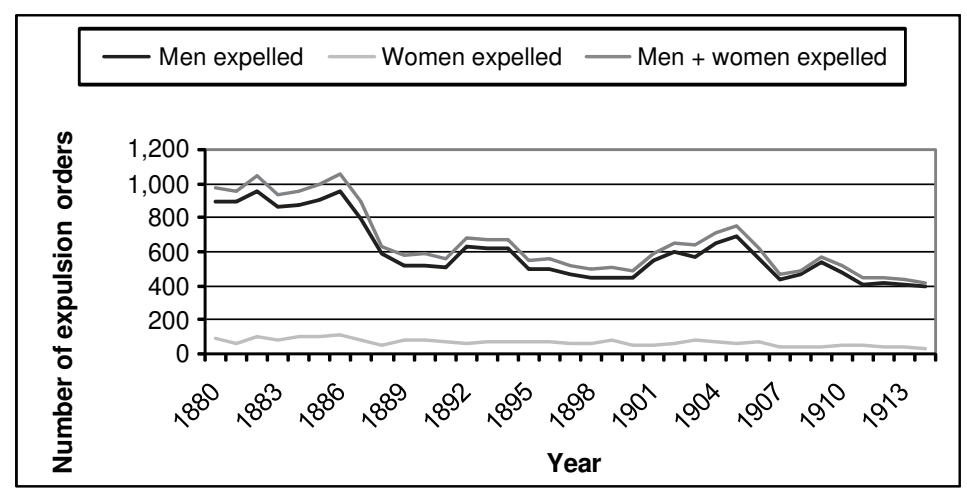


was lower for women than for men (see Van Eijl's chapter in this volume). She also estimates that 'during most of this period only io per cent of all expulsions involved women' - a figure that roughly matches the findings in the German case. Why women were less likely to be expelled than men is difficult to establish. In the case of Germany, they may have found an occupation more easily. Since at the turn of the century the demand for labour in the German economy, especially in agriculture, was high and women were paid lower wages than men, women were welcome workers. Moreover, the police may have been more lenient towards them than towards travelling men, who were more likely to be suspected of 'begging' and other offences. In this context, the analysis of the official grounds of expulsion offers further insight.

As the reasons given to justify the expulsions from the Reich reveal, men and women were deported on different grounds. Generally speaking, the aim of the Reichsverweisung was to remove either foreign criminals or the destitute and so-called 'vagrants' from the country. This measure was in line with older poor relief traditions, according to which paupers who did not have the right to settle in a municipality were 'liable to be deported to their home town, the next village or anywhere else' (Fahrmeir I997: 726). By the second half of the century, welfare structures increasingly became the domain of the state, and paupers were legally obliged to leave not only the municipality, but also the whole state if they were foreign citizens. In this context, the authorities focussed particularly on itinerant groups who had no fixed place of residence. Lucassen (I996) has described how the categorising and policing efforts of the German police and administration resulted in the labelling of highly mobile migrants as 'gypsies'. Groups with an itinerant way of life were repeatedly labelled as 'vagrants' or 'gypsies' and encountered a considerable degree of public hostility. In this context, Lucassen also refers to the fact that the discriminative treatment of the newly arriving 'foreigners' was closely related to the German system of poor relief.

The overall number of expulsions from the Reich was indeed mainly influenced by the number of migrants convicted of begging and vagabonding, whereas the number of orders following up criminal offences (including theft, fraud, prostitution or false papers) remained rather stable and was much smaller (about Io per cent). ${ }^{6}$ Hence in the majority of cases, foreigners were compelled to leave because they were found to be begging or 'vagrant'. This picture changes when we concentrate on the reasons for deporting female migrants from the Reich. Even though about one half (52.4 per cent) of the women who were expelled in I905 also had to leave because they were accused of begging or vagabonding, nearly one third (28.6 per cent) of the women listed 
were deported because of prostitution, while the frequency of stealing and fraud among them was comparatively similar to that of male deportees (II.9 per cent). ${ }^{7}$ Even though the diverse German states differed in their policy, prostitution was usually not prohibited if the prostitutes were registered with the police and under police surveillance, which implied regular medical examination. Hence foreign women who were convicted and deported probably had been arrested as 'unlicensed prostitutes'.

Prostitution was considered a specifically female offence, whereas procuring very seldom occurred among the reasons for men to be expelled and there was no case of a male immigrant being expelled as a prostitute. The contemporary reformist, juridical and sociological literature seldom refers to foreign women as being specifically liable to engage in prostitution (Wolzendorff I9II; Schmölder I9II). The discourse on forced prostitution and the so-called 'white slave trade' merely connected international mobility with sexual offences. Like most other European states, Germany had signed the international treaties on trafficking in 1904 and I9IO, and the issue was being publicly debated (Henne Am Rhyn I903; Schidlof 1904; Petters I9II; Bohne 1927). Contemporaries commonly presented the 'white slave trade' as a serious international problem, even though they seldom considered Germany its central destination. It is remarkable, though, that Russian Poland and Galicia, where the majority of immigrants in Germany came from, repeatedly figured as major hubs of trafficking. Polish and Galician Jews were frequently depicted as driving forces behind the trade, and the 'Jew-as-brothel-keeper' was an element of anti-Jewish imagery, in which sexualised, economised and racist components overlapped (Fritsche I893; Weihns i899: 3I-40; Wagener I9II: I8-32; Bohne I927).

Whether this image influenced the actual policing of immigrant women or not, whether it made them conspicuous in the eyes of the police or mirrored an existing problem, is difficult to tell. What can be assumed is that the deportation figures imply a gender-specific position of women in the Reich's moral economy. Mostly, expulsions from the Reich advanced the removal of the actual or potential recipients of poor relief, namely migrants who were suspected of lacking means of subsistence. Men were usually evicted as 'beggars' and 'vagabonds', while female migrants were more likely to be excluded on grounds of sexual immorality. One third of the women expelled from the Reich were accused of prostitution. Most of these women were single. In the face of economic and social insecurity, prostitution was an option that women repeatedly chose - or were forced to choose by others. If they were foreign citizens, however, being a prostitute or being charged with prostitution threatened their further stay in the Reich. Their sexual beha- 
viour or suspected sexual immorality became a factor justifying their removal from the state.

That migrant women who engaged in prostitution were in danger of acquiring an illegal status is suggested by the following example. In April I905, the Austrian migrant Karoline Bobeck faced expulsion from the Reich and wrote a letter to the Prussian Minister of the Interior, pleading to be allowed to stay. ${ }^{8}$ She had been living in the country for two years when she suddenly lost her job. Soon after, she, as she put it in her letter, 'came into conflict with the vice squad'. Even though she then tried everything to earn a living, she received an expulsion order. Since she wanted to stay in Berlin, she assumed a false name and stayed. After she was caught by the police a second time, she pleaded in writing to be allowed to stay and seek 'decent employment'. But although she declared that she was not 'immoral' but 'a woman driven by misfortune', the ministerial officials denied her request. She was expelled.

Very few documents in the files of the Prussian Ministry offer insight into the individual stories behind expulsions on moral grounds. It is thus difficult to say if Bobeck presented her 'true story', or if hers was a typical fate. Her example does point to the insecure residence status and its effects as central features of the German migration regime. Migrants living in the Reich did not have any right to stay. If they lost their employment, did not have a place of residence or for other reasons became a potential public charge, they risked being deported. This affected both women and men, with women being more likely to be suspected of prostitution and deficient sexual morality especially if they were unmarried. This different moral logic did not just apply to German immigration policy. In her analysis of late nineteenth-century US deportation practices, Moloney (2006: I00) has shown how efforts to deport immigrants that referred to 'concerns over sexual morality' had 'more profound effects on women'. According to Moloney, this focus on women's sexual morality was intertwined with assumptions about their economic roles as being dependent on male wages, and clearly put single immigrant women at a disadvantage. The fact that in the German case most of the women who were expelled after being charged with prostitution were single at least suggests that a similar mechanism influenced their treatment. Generally speaking, however, the deportations from the Reich in the name of public security threatened to punish any form of 'deviant' behaviour, be it so-called vagrancy, criminality or prostitution. In this respect, the Reichsverweisung functioned as an instrument of social control. 


\subsection{Poles, Jews and Prussian wives: Migration control and the expulsions from Prussia}

Presumably because they were based on juridical decisions and because they required officials to institute formal legal proceedings, the overall number of expulsions from the Reich was limited and decreased before the First World War. Expelling foreigners as 'undesirables' from Prussia, however, (i.e. from a German state) was an instrument frequently employed by state officials in order to regulate immigration. Although expellees were legally allowed to move from one German state to another after their expulsion, the German Länder often did not accept deportees from other German states. This meant that that in most cases to be expelled from Prussia meant to be expelled from the whole of Germany (Gosewinkel 200I: 220). In Prussia, expulsions generally were deemed acceptable in the interest of 'public safety, peace and order'. They did not follow any juridical decision but could be ordered by state officials, who in that respect possessed far-reaching powers.

These deportations have to be seen in the context of an ethnically exclusive nationalist policy, which aimed at excluding foreign Polish and Jewish migrants in particular. Throughout the late nineteenth and early twentieth centuries, Prussian authorities repeatedly ordered the deportation of foreign citizens, not for any individual reason but on account of their ethnicity. In this context, ethnic, religious, political and economic mechanisms of exclusion overlapped. According to the logic of this practice, the proletarian, poor, Jewish or Polish-Catholic migrant was looked on as the undesired migrant incarnate, especially if he or she was politically active. Anti-Polish and anti-Semitic tendencies triggered the mass expulsions of the mid-I88os, as a result of which about 32,000 foreign Poles and Jews were forced to leave Prussia (Neubach I967). And an anti-Polish impulse characterised the elaborate system of migration control that Prussian authorities set up in the I8gos.

Both male and female foreign citizens were affected by these measures and their racist tendencies. Their situations with regard to expulsion differed nevertheless. The most obvious had to do with the distinct legal positions they occupied under German law (Gosewinkel 200I: 294-303; Trevisiol 2005: 20I-208). According to the citizenship laws of I870 and I9I3, women acquired citizenship via their fathers and husbands. When marrying, they automatically assumed their husband's nationality. Hence Prussian-born women who married foreign citizens lost their German nationality. Because of dependent citizenship they could be deported despite their being born in Germany. In general, deportations not only concerned the deportees, but also their partners and children. That both expellees and state officials were con- 
stantly struggling with this role of the family becomes apparent in the case of mixed marriages.

Generally speaking, female and male migrants entering into a mixed marriage in late nineteenth-century Germany faced different consequences. A woman of foreign nationality who married a German man immediately acquired protection from deportation, since she automatically became a German national. Single women were seldom naturalised, even though it was possible - authorities rather expected them to gain German citizenship via marriage (Trevisiol 2005: 208). Theoretically, immigrant women could even try to circumvent their forced removal by entering into a bogus marriage. But even though contemporary legal literature in fact reflected that there was such a possibility, hardly anybody seems to have chosen it (Eisfeld 2005: 7I-84). There are very few documented cases of women marrying Prussian citizens in order to evade deportation; officials did not suspect a potential bogus marriage, nor is there any other indication of such a scenario. On the other hand, men of foreign nationality who married German-born wives could still be deported and could only change their insecure residence status by naturalisation. The German naturalisation practice tended to be rather restrictive, however, so this was hardly a promising option. While entering into a mixed marriage in Germany offered legal security for migrant women, it transferred an insecure status to German-born wives. In the following section, these different positions and the role of marriage in this context are analysed with a particular view to the Prussian policy of the I880s and I8gos.

The majority of the 44,000 foreign Polish and Jewish migrants who by 1885 were assumed to reside in Prussia's Eastern Provinces had moved there from Russia and Galicia. They were often denounced as 'deserters', since many had migrated in order to escape military service. But while several of them came for military reasons, not all of them did by any means. The term increasingly served as a general label for migrants from Eastern Europe. The majority of these Polish and Galician migrants were men. Many of them had been residing in the country for a considerable time and several were married to formerly Prussian women. In his study, Neubach gives the example of a municipality in West Prussia where 80 per cent of the foreign men who had a residence permit were reported to be married, and nine out of ten were said to have married Prussian women (1967: 57). These women - or the couples who at the time lived in a mixed marriage - were explicitly included in the deportation orders, as a result of which the vast majority of the foreign Poles and Jews had to leave Prussia in I885-86. As the Prussian Minister of the Interior specified in I885, Russian or Galician Poles who had married Prussian women were even regarded as 'elements' that were 'essential in causing the severe national problems' 
in the country. A mixed marriage, he claimed, was 'no reason' for exempting them or their families from deportation (Neubach I967: 6r; Bade I984: II4). Overall, in accordance with the anti-Polish and antiSemitic tendencies of their national policy, the Prussian authorities expelled about 32,000 citizens of foreign nationality who had lived in the Prussian Eastern provinces (Neubach 1967: 128).

Being born in Germany did not prevent Prussian-born wives from being deported. Intent on avoiding any further strengthening of the Polish and Jewish 'element', the ministerial officials deported them along with the others. But even though the Prussian policy of expulsion focussed primarily on foreign Polish and Jewish migrants, these groups were not the only ones subjected to deportation. As the Reich did, Prussia repeatedly evicted foreigners who were receiving poor relief. Van Eijl and Lucassen (2006: I87-193) have shown that Dutch migrants who were forced to leave late nineteenth-century Prussia because they received poor relief were evicted along with their Prussianborn wives. 9 Responding to social concerns, Prussian-born women were frequently forced to leave the country along with their destitute foreign husbands - be they Polish or not.

The fact that Prussian-born women could be forced to leave the German Reich points to the gendered conception of citizenship in late nineteenth-century Germany. If, as Brubaker maintains, a volk-centred definition of nationhood did indeed shape German citizenship law, women were partly excluded from that conception. They did not belong to a 'community of descent'; rather, they became part of the community they married into. First and foremost, marriage and the patriarchal family served as the major institutions for transferring citizenship. Therefore, it is not quite correct to assume that before I9I3 German law defined citizenship as a 'community of descent' with respect to the acquisition of citizenship and as a 'territorial community' with respect to the preservation of citizenship (Brubaker I992: II5). Brubaker's assumption that the German understanding of citizenship was expansive towards ethnic Germans and restrictive towards non-Germans also needs to be rectified (Brubaker I992: II4-I37). If it was expansive towards ethnic Germans, this mainly concerned German men, while women could lose their place in the German 'community of descent' quite easily.

In order to avoid a situation similar to that of the mass expulsions in 1885-86, Prussian officials during the following years sought to further reduce the chances of mixed relationships between Polish men and German women. After having officially - though not effectively - been banned from the country for a while, Polish workers from Galicia and Russia in I89o were re-admitted in response to the growing demand for labour in the Prussian economy. But in accordance with their anti- 
Polish nationalist concerns, authorities were eager to prevent foreign Poles from settling permanently. Therefore, they introduced a compulsory period of expulsion, so that Polish workers had to leave the country annually and could only return the next spring. ${ }^{\text {IO }}$ Nine out of ten foreign Polish workers left the country every autumn in order to return the following year. Responding to the need for labour in German agriculture and industry on the one hand, and hoping to prevent incoming workers from settling on the other, the Prussian state installed an increasingly complex system of regulations during the subsequent decade (Bade I979; I980; I984). After I908, every foreign Polish worker had to have a work permit that detailed the name of the employer by whom he or she was contracted. ${ }^{\text {II }}$ They were not allowed to change their workplace without authorisation. The Prussian officials were particularly concerned with the unauthorised and undocumented movement of the foreign workers in the country: migrant labourers who broke their contract or who did not possess a valid work permit risked immediate eviction. Generally speaking, to deport and expel migrants thus served as a crucial element in the strict Prussian migration regime as it was established in the late nineteenth and early twentieth centuries. In this context, the forced removal of Polish workers responded to the anti-Polish nationalist concerns of Prussia's elites, while at the same time their annual admittance to the country answered economic needs.

The Prussian authorities were particularly concerned that Polish seasonal workers would marry German women and have a family, fearing that the women in turn would be subjected to the annual autumn deportations - or that the whole family would try to settle in Prussia (Bade I984: II4). The forced removal of the Russian-Polish and Austrian-Polish migrants at the end of each year was a way to counteract these problems. Being eager to interfere with any further settlement of Polish families, Prussian officials hoped that the regulation would help to prevent marriages between foreign Polish men and German women. Moreover, the employers were only allowed to recruit single, and not married foreign workers. This regulation was not limited to migrant men. A high percentage of the seasonal workers employed in Prussia's economy were women. Especially in Prussian agriculture, female foreign labourers, who were paid less than their male countrymen and who, according to contemporary gender stereotypes, were seen as more capable of doing the monotonous work involved in Prussian hoe farming, were welcome labourers (Bright Jones I999, 2005). Like their male fellow workers, they had to be single. In addition, female foreign workers were to be deported once it was discovered they were pregnant. Whilst officially it was argued that the pregnancy reduced their work effectiveness and hence meant a deliberate breach of contract, 
authorities unofficially also hoped to ward off Polish women who had entered into a relationship with German men (Bade I984: II5). In accordance with their nationalist agenda, Prussian authorities aimed at preventing sexual contact between German men and migrant women. It was also feared that the children of Polish workers would increase the number of Polish people, whose higher birth rate was a matter of growing concern in the Reich, where the pro-natalist discourse on population was turning increasingly racist (Weindling I989). So the desire to prevent incoming Polish workers from entering into mixed relationships clearly had nationalist implications: politicians aimed at avoiding the 'Polonisation' of the Eastern provinces and were eager to protect 'German' family life from any Polish influences. As part of their nationalist 'Germanising' project, they attempted to regulate the sexual practices and marital behaviour of their own and of the foreign citizens.

The foregoing passages only refer to dealings on the level of official politics. The question of how these orders were implemented administratively, and how migrants reacted to them, has hardly been addressed. In fact, many orders were not strictly adhered to. Employers repeatedly hired married workers, and many workers who breached their contracts simply changed their workplace instead of leaving the country. Nevertheless, the official regulations reveal that state officials attempted to influence not only the way migrants could enter, work and stay in Prussia, but they also tried to regulate their marital lives. In her study on the history of marriage and the nation, Cott (2000: 3 ) argues that marriage as a public institution is 'a vehicle through which the apparatus of state can shape the gender order'. As the Prussian policy of migration control suggests, state authorities also sought to control marital behaviour in order to maintain an ethnicised national order. Their policy suggests an obsession with the maintenance of ethnicised boundaries reminiscent of the dynamics that McClintock (I995) has observed in Victorian imperial society. By requiring them to be single or by discouraging the pregnancy of foreign women, officials claimed influence over the most tangible circumstances of the immigrants' family and sexual lives. Their policy was inspired by a governmental rationality which endeavoured to ensure, rationalise and optimise the economic, social and biological functioning of 'the population' (Dean I999; Foucault 2004). The regulation of migration became part of the biopolitical efforts that came to characterise the modern state.

When defining the conditions of their stay and removal from the country, the influence of the state on migrants' relationships and everyday life became very concrete. In order to understand the migrants' perspective in this context, the following analysis concentrates on the way in which men and women living in a mixed marriage protested against their expulsions in the mid-I88os. 


\subsection{Dearest Emperor - Dearest Empress: Different patterns of protest}

Your Highness, unconquerable Emperor, merciful and mighty King and Lord! You Royal Majesty and highest Sovereign, who from his high throne deigns to look upon me, his humble and loyal subject, and who might want to pardon this unfortunate, out of benevolence and mercy.

Following this rather extensive salutation, the Russian-Polish migrant Joseph Konopka, who was facing deportation from Prussia in I886, petitioned the German emperor to annul the order against his family. ${ }^{\text {I2 }}$ He had been living in Eastern Prussia for seventeen years, was married to a formerly Prussian wife and was protesting this deportation. On the same day, a letter was posted to the German empress. Addressing herself to, 'Your highness, noble Empress, merciful Queen and Mistress', Charlotte Konopka, his wife, also requested to that the expulsion order be rescinded. ${ }^{\mathrm{I}}$ As their salutations suggest, Charlotte and Joseph Konopka chose different tactics in order to reverse the order against them. They, like many couples in their situation, showed differing patterns of protest, which reflected their differing positions in German society.

In general, male and female foreign citizens who were threatened with expulsion frequently tried to have the measure revoked. They usually wrote to the authority whose influence seemed most likely to be successful: to the Emperor, the Chancellor of the Reich or the Prussian Minister of the Interior. In fact, the latter was the right addressee, insofar as the ministerial officials were obliged to check if a Prussian expulsion order was to be enacted once a deportee petitioned officially. It was not possible to take legal action and appeal to a court. An analysis of the various petitions contained in the files of the Prussian Ministry of the Interior therefore not only offers insight into the actual administrative practice and the individual decisions of Prussian officials, ${ }^{\mathrm{I}}$ but it also reveals the ways in which foreign citizens reacted to the orders made against them. To protest in writing against an expulsion order was just one of several strategies that people applied in order either to question the order or to circumvent it. Not everybody who had been requested to leave Prussia or the German Reich actually did so - and many who did came back illegally. But whereas the Prussian state commonly labelled these strategies as 'irregular' and criminalised clandestine border crossings and the unsanctioned return of formerly expelled citizens by punishing them with imprisonment or renewed deportation, the petitions against expulsions were a legal way of pro- 
testing. Therefore, the letters and the official memoranda attached to them offer valuable insight into the actual circumstances under which foreigners were expelled and into the 'micro-mechanisms of power' (Foucault 2005: II3-II8) which determined the interaction between state authorities and individual foreign citizens. Generally speaking, migration controls can be understood as an element of the rationalising and standardising processes implemented by modern states in order to render a society 'legible', as described by Scott (I998: 2). But to fully understand this process, it is crucial to bear in mind that power involves a 'two-way or multilateral process of interaction between people who themselves have varying degrees of freedom of action to exert power as they wish' (Evans I998: 3). Migrants, to be more precise, were agents in their own right (Constantine 2006) and constantly challenged the state's attempt to monitor and control their mobility.

Only a particular type of migrant was likely to petition in writing. Most of the written pleas to review an expulsion order were written by merchants, businessmen and craftsmen from Austria-Hungary and Russia. Protests written by foreign workers were rare. Even though they had found various ways to circumvent the Prussian system of control, workers hardly ever petitioned against their expulsion. The social structure of the petitioners thus hardly reflects the overall structure of Prussia's migrant population during the pre-war period, which was dominated by industrial and agricultural workers. This can partly be explained by the fact that even though foreign Polish workers were required to leave the country annually, they were mostly asked to do so independently or were deported informally without any official expulsion order. In addition, not all agricultural and industrial workers could read or write by any means, so they would not engage in written correspondence (Constantine 2006: 328). Merchants, businessmen and craftsmen, on the other hand, were probably educated enough to protest in writing - or at least to pay somebody to do so. Also, it was mostly men who wrote petitions; only a few letters were written by women. In addition, the majority of women who appealed to the authorities were former Prussian citizens who had assumed their husbands' citizenship when marrying. Despite the high percentage of female foreign workers in Prussia, their voices are hardly represented. Since no sufficient statistical data exist on the actual numbers of orders or on the petitions against the orders, it is impossible to quantify how many petitions were successful and on what grounds. It can be said though, that frequent petitions against expulsion orders were a rather efficient means of prolonging the stay - if not indefinitely, then at least for a rather long time. In numerous cases, the Prussian authorities allowed the deportees to remain in the country for a few more months and in some cases the orders were suspended for years. 
As the various petitions documented in the files of the Prussian Ministry show, male and female foreign citizens tended to choose different addressees for their pleas. Whereas men wrote to the emperor, the chancellor or the Minister of the Interior, women frequently addressed themselves to the emperor's wife. Even though the empress did not have any specific political power, they seemed to assume that she as a woman was more likely to be sympathetic to their problems. Like Charlotte Konopka, Hedwig Kohane was a former Prussian citizen who had married a foreign migrant, in this case a Galician. The couple was about to be expelled in I886. But whereas her husband wrote to the Prussian Minister of the Interior in order to protest against the order, Hedwig Kohane addressed herself to the German empress. In her letter, she not only pointed out that she had been raised by German parents, but she also emphasised that her husband was to be considered 'German in his attitude and nature'. He was honest and working successfully. And even with a view to his education, she declared, her husband was 'typically German' ('urdeutsch'). Having thus pointed out the exemplary integration of her husband into German culture and economic life, Hedwig Kohane finished her letter by appealing to the empress as 'the eminent protector of German family life' to help her. ${ }^{\text {I5 }}$

In order to prevent her family from being sent to Galicia, Kohane presented herself as a guardian of German family life and underlined her own 'Germanness' as well as that of her husband. She thus contradicted the official legal status allotted to her by a citizenship law which was based on a patriarchal concept of family and marriage. By referring to the importance of both their German identity and their status as mothers and wives, the formerly Prussian women claimed their own place in the national community, to which they declared to belong by birth and irrespective of their having married a foreigner. Despite the fact that they had lost their nationality when marrying, formerly Prussian wives often still thought of themselves - or at least presented themselves - as 'being German'. They also emphasised that they were conveying 'German culture' to their families and frequently declared they were raising their children according to 'German values'. Whereas the principle of dependent citizenship was hardly an issue at the political level in the I880s and I89os, it was by no means a matter of course for the women who were concerned.

After having lost, through marriage, a secure residence status along with their former nationality, these women risked being sent to a country they had never been to before - or they feared being left behind in Germany without their husbands. Consequently, Prussian-born women who protested against their impending expulsion referred to the hardships awaiting them. They pointed out that neither they nor their children could speak the language of the country they were being expelled 
to. They evoked the vision of a future life in poverty somewhere abroad by arguing that their husbands would have difficulty making a living. And they stated that they still had relatives in Germany who needed to be cared for and looked after. Apart from the anti-Semitic and antiPolish agenda of Prussian policy, poor relief was indeed a central argument behind expulsions. Local as well as ministerial officials were usually eager not to be saddled with either the deportees' families left behind or with other relatives in need of constant care. Due to the common assumption that women were economically dependent on male wages, it was suspected they would likely become a public charge if separated from their husbands. Therefore, during the mass expulsions in the mid-I88os as well as later, Prussian-born women were usually deported along with their husbands. ${ }^{16}$ Nevertheless, authorities were not interested in having German relatives on their hands who were in need of care and whose daughters or nieces had been forced to leave the country. In those cases, officials repeatedly agreed to suspend orders which they assumed would otherwise increase the burden on public care. Whereas their presumed economic dependency heightened the chance that women would be expelled along with their husbands, their claim of having relatives to care for in some cases delayed their own and their husband's deportation.

Like their wives, protesting men usually presented their marriage to a Prussian woman as a clear sign of their integration. Not only did they declare having lived in the country for a long time, but they also pointed out that having married a local citizen demonstrated their near-Germanness. Several of the male petitioners assumed that their marriage would help to promote a secure residence status, so that a Russian-Pole who was facing expulsion in 1885 asked incredulously, 'But Excellency, do those who have domestic wives also have to leave?'17 In addition, petitioners repeatedly presented their imminent removal from Prussian territory as an impending loss of Heimat. Martin Kainer, a Galician who had immigrated to Prussia as a child, described himself as 'a good German and Prussian', as a 'loyal servant to His Majesty' and a 'good citizen' who had married a Prussian woman and who owned a successful business. If he was sent back to his country of origin, he argued, he would not only lose his business, but was also likely to encounter linguistic problems, as he did not properly understand the Polish spoken there. ${ }^{18}$ Like him, many long-term residents who were facing deportation declared to be estranged from their official country of origin. Therefore, issues of identity, language and belonging played a central role in the deportees' pleadings. Being threatened with the removal from the country, they reacted by referring to their German-born wives, German education and German character. In addition, they strove to present themselves as 'good German citizens' by 
underlining that they were paying taxes, that they had not committed any criminal offence and that they or their sons had served in the army. In March I898, N. Ehrlich, a Russian Jew, addressed himself to the Senate of Bremen. In his letter, Ehrlich described himself as a merchant with a considerable annual income and produced receipts of his donations to 23 Prussian charitable institutions in order to document that he 'knew the duties of a good citizen'. ${ }^{19}$ Nevertheless, he and his sons were expelled from Berlin. Having been forced to leave Prussia, Ehrlich now requested permission to take up residence in Bremen. Like many other petitioners confronted with the Prussian policy, he did not understand how he as a 'good citizen' could be expelled.

Being faced with their impending removal from German territory, petitioners were likely to use those arguments that they expected to be most successful. Rather than depicting their situation as they saw it, they were presenting their situation as it was most likely to be accepted. Presupposing a certain ideal of a good citizen, many male Protestants underlined their affinity to German culture and their high degree of integration. They frequently pointed out that they were economically successful and that they were not likely to become a burden on poor relief. And they emphasised that they were paying taxes or that they had served in the army. In this context, the differing situations of men and women became evident. Men usually found it easier to prove they could support a family and fulfil the classical military and fiscal duties of a citizen, so they mostly cited their economic, social and political reliability. Female petitioners (who in this case were mostly Prussian-born women) usually left out their own economic situation and rather spoke on their husbands' behalf. They also referred to their children or relatives in their care and pointed to the potential hardships awaiting them if they were either left behind or sent to another country. So if they referred to their own position, female petitioners usually alluded to those niches which contemporary middle-class ideology allotted them: the family and the care of close relatives. Whether this account mirrored their 'real situation' is difficult to say, but at least it was the line of argument deemed most successful by the petitioners. Despite having lost their former citizenship when marrying, these women also commonly presented themselves as guardians of German values and conveyors of a German identity. They claimed a position they did not possess under German citizenship law. This was similarly true for their husbands, who frequently underlined their own 'Germanness', even though they were foreign citizens on paper. In the case of mixed marriages, the citizenship allotted to the couples and the nationality both partners identified with did not always correspond. Their concepts of membership and belonging challenged the principles on which citizenship law was based. At the same time, their predominant claim 'to 
be German' also mimicked the central nationalist concern with 'Germanness' that did characterise Prussian expulsion policy at the time. In fact, it was due to that concern that the majority of the petitioners had to leave the country, despite their protests.

\subsection{Conclusion}

The expulsion of foreigners in late nineteenth-century Germany was closely connected to the emergence of modern state structures and the process of a 'nationalisation of the social', as Noiriel has described it (1994). Nation-states were striving to strengthen the bonds between the state and its citizens by defining the actual rights and benefits of belonging. At the same time, they also defined more clearly who was to be left out - excluded in the very spatial sense of not being admitted to the country, or less literally in being denied citizenship and civil, political or social rights (Marshall 1949). The administrative practice of evicting unwelcome foreigners illustrates how important nationality had become as a distinctive criterion that shaped the relationship between the state and the individual. Whereas in earlier years membership in a municipality or status groups had been crucial, at the end of the nineteenth century it was citizenship that determined the access to rights and benefits. That non-Germans in the German Empire could be compelled to leave, whereas German citizens were protected from deportation, points to the wide-ranging implications that belonging to a nation could have. While citizenship law provided a legal definition of who belonged to the nation and who did not, the expulsions revealed how relevant citizenship had become in everyday life.

In this chapter, the practice of expelling foreign citizens has been analysed from three aspects: $\mathrm{I}$. The differences in expelling immigrant men and women from the Reich, 2. the different positions of male and female foreign citizens in the context of Prussia's nationalist policy, 3 . the strategies chosen by male and female deportees in order to protest their imminent removal. Functioning as an instrument of social control, the Reichsverweisungen threatened to sanction any form of 'deviant' behaviour, be it the so-called 'vagrancy', prostitution or criminality. Immigrants who lost their employment, or for other reasons became a likely public charge, risked being deported. In this context, immigrant women were more likely to be expelled than men because of their alleged sexual immorality, especially if they were single. In addition to a potential lack of economic means, their being suspected of prostitution became an important factor justifying their forced removal.

As part of the ethnically exclusive agenda of their policy, Prussian authorities in the late nineteenth century aimed at preventing Polish 
and Jewish migrants from residing permanently in the country. In this context, mixed marriages between Polish migrants and local citizens were a matter of particular concern. From the I89os onwards, the Prussian authorities tried to reduce the possibility of male Polish migrants entering into mixed marriages - as well as of female migrants either marrying or becoming pregnant. The Prussian state officials not only endeavoured to influence the way in which migrants entered and stayed in Prussia, but they tried to regulate their marital and sexual lives as well. Their exclusive endeavours extended to women who were born in Prussia but who had married a foreigner. Although they were German-born, they were evicted along with their husbands.

While the anti-Polish and anti-Semitic intentions driving the Prussian expulsions concerned men and women alike, the legal principle of dependent citizenship affected them differently. Consequently, formerly Prussian wives and their immigrant husbands chose different strategies when protesting against their imminent eviction. While men found it easier to prove they could support a family and fulfil the military and fiscal duties of 'a good citizen', female petitioners spoke rather on their husbands' behalf or pointed to the potential social hardships awaiting them. Unlike their husbands, they usually did not present themselves as 'good citizens' in an economic, political or fiscal sense. Prussian-born women did, however, challenge the principle of dependent citizenship by frequently claiming to 'be Germans' and to convey 'Germanness' to their families. Like their husbands, they repeatedly emphasised that their official citizenship did not correspond to their sense of membership and belonging. The petitioners frequently challenged the exclusionary logic of Prussian expulsions, in which citizenship law and a restrictive immigration policy came to overlap.

The fact that formerly German women were evicted from the German Reich draws attention to the gendered nature of citizenship law. Moreover, it shows that historical interpretations of the relationship between nationalism and citizenship law have been imprecise because they overlooked these specificities. Brubaker's claim that a volk-centred definition of nationhood and the principle of jus sanguinis shaped German citizenship law leaves out the position of women. Despite their being German 'by descent' or 'by blood', women who married foreign immigrants not only had to change their citizenship, but they also risked eviction from the country if they were deemed unwelcome for social or ethnic reasons. In this respect, citizenship law in the Kaiserreich as well as the actual administrative practice of migration control gave precedence to patriarchal ideas of family and marriage, according to which husbands and fathers determined the nation to which all family members belonged. Unlike German men, women lost their place 
in the German 'community of descent' easily - and literally so, as they could be forced to leave the country.

The exclusive mechanisms at work in the field of immigration control were gender-specific, as well as classed and ethnicised. The practice of evicting foreigners was employed to police foreigners considered to be 'dangerous', 'degenerate' or 'unwelcome', as well as paupers and prostitutes, Poles and Jews. The evictions not only concerned those who were seen as potential or de facto burdens on poor relief, but they also aimed at excluding non-Germans as part of an ethnically exclusive nationalist policy. In this context, the boundaries between wanted and unwanted foreigners were constantly being defined and re-defined along the lines of race, class and gender. In order to understand the late nineteenth-century policy of restricting movement, this nexus between ethnicised, classed and gender-specific mechanisms of exclusion must be taken into account.

\section{Notes}

I Geheimes Staatsarchiv Preußischer Kulturbesitz, Berlin (henceforth: GStA), I HA, Rep. 77, tit. II76, I G, Vol. I, Letter by Marie Gad.

2 Strafgesetzbuch, $\int 38-39,284,36 \mathrm{I}-362$.

3 See the data in the official periodicals Zentralblatt für das Deutsche Reich,Deutsches Fahndungsblatt and the annual balance as it was published in the Statistisches Jahrbuch für das Deutschen Reich.

4 Data taken from Elsner and Lehmann (I988: 25).

5 Numbers as published annually in the Statistisches Jahrbuch für das Deutschen Reich, I890 to I9I4.

6 In I905, 7.7 per cent of the deportation orders were based on $\$ 39$ of the Criminal Code, whereas about 9I per cent of the cases were based on $\int_{3} 62$. Of the decisions based on $₫ 39,69$ per cent had to do with vagrancy, theft or fraud, about I5.4 per cent with prostitution and procuring and the rest with false identity papers or false names. Of the decisions based on $₫ 362,87.5$ per cent had to do with begging and vagrancy, I2.5 per cent with theft and similar offences, 5.5 per cent with prostitution and 3.5 per cent with false identity papers.

7 Percentages are based on a sample of 313 orders, as published in the Zentralblatt für das Deutsche Reich 33 (I905).

8 GStA, I HA, Rep. 77, Ministerium des Innern, tit. II76, No. 4B, Vol. I, letter by Karoline Bobeck.

9 In I908, Germany and the Netherlands came to agree that Dutch emigrants who were receiving poor relief would not have to be deported if the Dutch government bore the costs for their support (Van Eijl \& Lucassen 2006: I9I).

Io In I9I0 alone, 790,I89 foreign workers came to Prussia. The majority did not stay permanently: 498,777 left the country at the end of the year. The number of Polish workers who came in I9I0 was 253,935, 249,908 of whom left in December.

II After I909 this regulation was extended to all foreign workers.

I2 GStA, I HA, Rep. 77, tit. II76, Nr. I K, Vol. 2, 58-64.

I3 ibid., 63f. 
I4 The following analysis is based on a collection of petitions that reached the Prussian Ministry of the Interior between the mid-I88os and the turn of the century. The respective files concern expulsion orders against citizens from either Russia or AustriaHungary. All files are taken from GStA, I HA, Rep. 77, tit. II76, Nr. I G; K.

I5 GStA, I HA, Rep. 77, tit. II76, Nr. I K, Vol. 2, Io7f.

I6 See, for example, the comments on the case of a Mrs. Gottheiner GStA, I HA, Rep. 77, tit. II76, Nr. I G, Vol. I, Io. The district president commented that she was born a Prussian but lost her citizenship through marriage. Since it was 'to be expected that Gottheiner's wife would become a burden on poor relief in Kerzlow', the local head of the administration decided to deport her. For a similar argumentation see also the case of Caroline Gerning (ibid. 7of).

I7 GStA, I HA, Rep. 77, tit. II76, Nr. I G, Vol. I, 92f, Letter by Michael Gutowski.

I8 GStA, I HA, Rep. 77, tit. II76, Nr. I K, Vol. 2, 4I-44.

I9 Staatsarchiv Bremen, 4,I4/I-IV.D.6, Bl. 8, Letter by N. Ehrlich, 30 March I898.

\section{References}

Bade, K. (I979/2005), Land oder Arbeit? Transnationale und interne Migration im deutschen Nordosten vor dem Ersten Weltkrieg. www.imis.uni-osnabrueck.de/BadeHabil.pdf.

Bade, K. (I980), 'Politik und Ökonomie der Ausländerbeschäftigung im preußischen Osten I885-I9I4: Die Internationalisierung des Arbeitsmarktes im "Rahmen der preußischen Abwehrpolitik”, in H.-J. Puhle (ed.), Preußen im Rückblick, 273-299. Göttingen: Vandenhoeck \& Ruprecht.

Bade, K. (I984), “"Preußengänger” und “Abwehrpolitik”: Ausländerbeschäftigung, Ausländerpolitik und Ausländerkontrolle auf dem Arbeitsmarkt in Preußen vor dem Ersten Weltkrieg', Archiv für Sozialgeschichte I4: 9I-I62.

Böcker, A. (ed.) (I998), Regulation of migration: International experiences. Amsterdam: Het Spinhuis.

Bohne, G. (I927), 'Mädchenhandel', in F. Stier-Somlo (ed.), Handwörterbuch der Rechtswissenschaft. Vol. 4, Berlin: De Gruyter.

Bredbenner, C.L. (I998), A nationality of her own: Women, marriage and the law of citizenship. Berkeley: University of California Press.

Bright Jones, E. (I999), 'The gendering of the postwar agricultural labor shortage in Saxony, I918-1925', Central European History 32: 311-29.

Bright Jones, E. (2005), 'Landwirtschaftliche Arbeit und weibliche Körper in Deutschland I9I8-I933’, in B. Binder (ed.), Ort. Arbeit. Körper. Ethnographie Europäischer Modernen, 469-476. Münster: Waxmann.

Brochmann, G. \& T. Hammar (eds.) (I999), Mechanisms of immigration control: a comparative analysis of European regulation policies. Oxford: Berg.

Brubaker, R. (1992), Citizenship and nationhood in France and Germany. Cambridge: Harvard University Press.

Caestecker, F. (I998), 'The changing modalities of regulation in international migration within continental Europe, I870-I940', in A. Böcker (ed.), Regulation of migration. International experiences, 73-98. Amsterdam: Het Spinhuis.

Caestecker, F. (2003), 'The transformation of nineteenth-century West European expulsion policy, I880-I9I4', in A. Fahrmeir, O. Faron \& P. Weil (eds.), Migration control in the North Atlantic World: The evolution of state practices in Europe and the United States from the French Revolution to the Inter-War Period, I20-137. New York: Berghahn Books.

Constantine, S. (2006), 'Migrant labour in the German countryside: Agency and protest, I890-I923', Labor History 47: 3I9-4I. 
Cott, N.F. (2000), Public vows: A history of marriage and the nation. Cambridge: Harvard University Press.

Dean, M. (I999), Governmentality: Power and rule in modern society. London: Sage.

Eisfeld, J. (2005), Die Scheinehe in Deutschland im 19. und 20. Jahrhundert. Tübingen: Mohr Siebeck.

Elsner, L. \& J. Lehmann (I988), Ausländische Arbeiter unter dem deutschen Imperialismus. 1900-1985. Berlin: Dietz.

Evans, R.J. (I998), Tales from the German underworld: Crime and punishment in the nineteenth century. New Haven: Yale University Press.

Fahrmeir, A. (I997), 'Nineteenth-century German citizenships: A reconsideration', The Historical Journal 40: $72 \mathrm{I}-75^{2}$.

Fahrmeir, A. (2000), Citizens and aliens: Foreigners and the law in Britain and the German states, 1789-1870. New York: Berghahn Books.

Fahrmeir, A., O. Faron, \& P. Weil (eds.) (2003), Migration control in the North Atlantic world: The evolution of state practices in Europe and the United States from the French Revolution to the Inter-War Period. New York: Berghahn Books.

Foucault, M. (2004), Geschichte der Gouvernementalität. Frankfurt/M.: Suhrkamp.

Foucault, M. (2005), Analytik der Macht. Frankfurt/M.: Suhrkamp.

Fritsche, M. (I893), Die schwarzen Juden und der jüdische Mädchenhandel: Sensationsroman. Berlin: C. Wald.

Gardner, M. (2005), The qualities of a citizen: Women, immigration and citizenship, 18701965. Princeton: Princeton University Press.

Gosewinkel, D. (200I), Einbürgern und Ausschließen: Die Nationalisierung der Staatsangehörigkeit vom Deutschen Bund bis zur Bundesrepublik Deutschland. Göttingen: Vandenhoeck \& Ruprecht.

Hart, B. de (2003), Onbezonnen Vrouwen: Gemengde relaties in het nationaliteitsrecht en het nationaliteitsrecht en her vreemdelingenrecht. Amsterdam: Het Spinhuis.

Henne Am Rhyn, O. (I903), Prostitution und Mädchenhandel: Neue Enthüllungen aus dem Sklavenleben weißer Frauen und Mädchen. Leipzig: Ronninger.

Isay, E. (I923), Das deutsche Fremdenrecht. Berlin: Stilke.

Lucassen, J. \& Lucassen, L. (eds.) (I997), Migration, migration history, history: Old paradigms and new perspectives. Bern: Lang.

Lucassen, L. (I996), Zigeuner: Die Geschichte eines polizeilichen Ordnungsbegriffes in Deutschland 1700-1945. Cologne: Böhlau.

Lucassen, L. (2002), 'Administrative into social control: The aliens police and foreign female servants in the Netherlands, I918-40', Social History 27: 327-42.

Marshall, T.H. (I949/ı992), Bürgerrechte und soziale Klassen: Zur Soziologie des Wohlfahrtsstaates. Frankfurt: Campus.

McClintock, A. (I995), Imperial leather: Race, gender and sexuality in the colonial contest. New York: Routledge.

Moloney, D.M. (2006), 'Women, sexual morality, and economic dependency in early U.S. deportation policy', Journal of Women's History I8: 95-I22.

Neubach, H. (1967), Die Ausweisungen von Polen und Juden aus Preußen 1885/86: Ein Beitrag zu Bismarcks Polenpolitik und zur Geschichte des deutsch-polnischen Verhältnisses. Wiesbaden: Otto Harrassowitz.

Noiriel, G. (I994), Die Tyrannei des Nationalen: Sozialgeschichte des Asylrechts in Europa. Lüneburg: zu Klampen.

Oltmer, J. (ed.) (2003), Migration steuern und verwalten: Deutschland vom späten 19. Jahrhundert bis zur Gegenwart. Göttingen: Vandenhoeck \& Ruprecht.

Petters, W. (I9II), Der Mädchenhandel und seine Bekämpfung nach geltendem und zukünftigen Reichsstrafrecht. Heidelberg: Hörning. 
Roller, K. (I994), Frauenmigration und Ausländerpolitik im Deutschen Kaiserreich: Polnische Arbeitsmigrantinnen in Preußen. Berlin: Dieter Bertz.

Schidlof, B. (I904), Der Mädchenhandel: Seine Geschichte und sein Wesen. Berlin: H. Steinitz.

Schmölder, R. (I9II), Unsere heutige Prostitution. Munich: Reinhardt.

Sciortino, G. (2004), 'Between phantoms and necessary evils: Some critical points in the study of irregular migrations to Western Europe', IMIS-Beiträge 24: I7-45.

Scott, J.C. (1998), Seeing like a state: How certain schemes to improve the human condition have failed. New Haven: Yale University Press.

Stoler, A.L. (I995), Race and the education of desire: Foucault's history of sexuality and the colonial order of things. Durham: Duke University Press.

Torpey, J. (2000), The invention of the passport: Surveillance, citizenship and the state. Cambridge: Cambridge University Press.

Trevisiol, O. (2005), Die Einbürgerungspraxis im Deutschen Reich 1871-1945. http://w3.ub. uni-konstanz.de/vi3/volltexte/2005/I482//pdf/Trevisiol_Diss_I5_02_05_bearbeitet.pdf.

Van Eijl, C. \& L. Lucassen (2006), 'Les Pays-Bas au-delà de leurs frontières, I850-I940', in N.L. Green \& F. Weil (eds.), Citoyenneté et émigration: Les politiques du départ, I8II99. Paris: Editions de l'EHESS.

Von Conta, W. (I904), Die Ausweisung aus dem Deutschen Reich und aus dem Staat und der Gemeinde in Preußen. Berlin: F. Vahlen.

Wagener, O. (I9II), Der Mädchenhandel. Berlin-Lichterfelde: Langenscheidt.

Weihns, W. (I899), Bordell-Juden und Mädchenhandel: Ergänzung zu der Schrift 'JudenBordelle'. Berlin: P. Heichen.

Weindling, P. (1989), Health, race and German politics between national unification and Nazism, 1870-1945. Cambridge: Cambridge University Press.

Wolzendorff, K. (I9II), Polizei und Prostitution. Tübingen: Laupp. 



\title{
4 Gendered borders: The case of 'illegal' migration from Iraq, the Horn of Africa and the former Soviet Union to the Netherlands
}

\author{
Ilse van Liempt
}

The smuggling and trafficking of human beings has received wide attention from politicians, the media and academia. Most studies in this field, however, are conducted by criminologists and as a result focus specifically on crime. Much research about smuggling and trafficking looks at the organisations involved in the 'business', the cooperation between different actors involved and the profits that are made (Salt \& Stein 1997; Kleemans Van den Berg \& Van de Bunt 1998; Salt \& Hogarth 2000; Aronowitz 200I; Van Dijk 2002; Staring, Engbersen, Moerland, De Lange, Verburg, Vermeulen \& Weltevrede 2005; Soudijn 2006). Furthermore, the majority of the studies in this field are policydriven and look at smuggling and trafficking from within a security framework (see also De Genova 2002). As a result of this criminological and policy-driven perspective, smuggling or trafficking is generally framed and understood in terms of the legal categories that define these issues. I will argue that we need a more actor-oriented approach that focuses on the strategies employed by migrants in response to these legal frameworks if we want to understand what is really going on.

This chapter is based on ${ }^{6} 6$ life stories of migrants (4I men and fifteen women) who were assisted in their migration from Iraq, the Horn of Africa and the former Soviet Union to the Netherlands. The data were collected between May 2003 and May 2004 for my PhD research (Van Liempt 2007). In this chapter, I will take a closer look at the gendered aspects of assisted types of migration. So far, little is known about the differences between men and women in these migration processes. In general, it is often assumed that most of the smuggled migrants are men (with agency) and most of the trafficked migrants are women (without agency). However, there is no evidence to support this claim, since there are no reliable data on the numbers of smuggled or trafficked migrants (see also Anderson \& O'Connell Davidson 2006). I will examine the different opportunities of female and male migrants in terms of 'illegal' migration and the decisions they have made within this framework. Despite its many drawbacks, the term 'illegal migration' is used here for the sake of clarity and coherence (see also the introduction to this volume). I will use the term within quotation marks to stress the fact that these types of migration are considered 'illegal' by 
states but can be very legitimate from a migrant's point of view (Van Liempt 2007). I will argue that the type of assistance migrants need in the absence of legal migration opportunities differs greatly from region to region and is not easy to capture in static legal categories. It is easier to understand how people have travelled, under what circumstances and with what intentions, if we do not specifically label them or their journeys as 'illegal'. This is not only important for understanding what is really happening on the ground, but also because legal frameworks differ considerably over time. Assistance for people who are not officially allowed to migrate is not new. For instance, in the ig6os, many labour migrants, from countries where guest workers were officially recruited by Northern European countries, entered 'spontaneously', outside the state-guided framework. Those who were not officially recruited, or who migrated after the official recruitment programmes had stopped, often came through 'illegal' channels. Some of them were helped by what we would now call smugglers (Berger \& Mohr I975). However, the context in which such forms of assisted migration take place has changed. Those who came 'illegally' to the Netherlands in order to work in the I970s did not face many obstacles in regularising their status after arrival. It was relatively easy to obtain a national insurance number with which most workers could find a legal job even when their legal status was not secure.

\subsection{Smuggling/trafficking}

Since 2000 , the law has made a distinction between smuggling and trafficking (before that time the two terms were used interchangeably). The Palermo Protocol differentiates smuggling from trafficking by the fact that in case of smuggling, the criminal act lies in the 'illegal' border crossing, whereas with trafficking the criminal act is associated with coercion and exploitation. Hardly any attention is paid to the reasons why these migrants need to travel in such a way or to the lack of alternatives they face (Van Liempt 2007). Smuggled migrants are also often portrayed as 'destitute' or 'desperate', whereas in reality they are often relatively well-educated and from less deprived socio-economic backgrounds (see also De Haas 2006). Despite the fact that only smugglers can be convicted for bringing someone 'illegally' across a border, smuggled migrants are often treated as criminals, too.

With trafficking, by contrast, international borders do not necessarily have to be crossed. The profit does not result from the movement itself but rather from migrant's work in the country of destination. Trafficked migrants are portrayed as victims more often than smuggled migrants. They are talked about as objects of traffickers, without any form 
of agency (see also the introduction to this book for this victimhood discourse).

However, the legal division between smuggling and trafficking oversimplifies the demarcation between voluntary and involuntary processes of migration. There are clear-cut cases of trafficking in which a migrant is kidnapped and trafficked completely against her will. But the majority of cases are much more complex and defy easy categorisation. Some trafficked prostitutes, for example, leave their country of origin with full consent, as a strategic action to improve their situation, but then end up in exploitative situations. The vast majority of migrants have some agency, and it is unusual for them not to have any choice or receive any benefit in the process. Migrant women working in prostitution are, however, often framed a priori as victims of trafficking without any agency, even when it was their own decision to work in the sex industry (Doezema 2002; Andrijasevic 2004).

Smuggled migrants, on the other hand, may be deceived or maltreated by their smuggler even when they themselves contacted them and consented. Smuggled migrants can become victims of trafficking during or even after the migration process, making it hard to draw a line between the two (Van Liempt 2006). It is therefore not very helpful to view trafficked migrants exclusively as having migrated against their will and smuggled migrants as the opposite. Migrants in general often face few choices when fleeing persecution or social and economic insecurity. Yet this does not mean they are without agency. Migrating with help from a smuggler may very well be the only way to escape violence, to join one's husband or wife in another country, or to secure one's standard of living. The smuggling of migrants can even be regarded as a response to humanitarian needs. Article 3I of the Geneva Convention explicitly recognises that asylum seekers might need to enter a safe country through 'illegal' means. Indeed, individuals today must increasingly adopt 'illegal' strategies in order to be in a position to make a formal asylum claim (see also Morrison \& Crosland 2000).

Since the I990s the term 'smuggling' has started to be used more widely in reference to 'illegal' forms of assistance. At that time many 'spontaneous' asylum seekers started to come from countries with which no prior links existed. The level of protection these 'spontaneous' asylum seekers needed was no longer taken for granted, and the term 'bogus asylum seeker' was introduced. Smugglers who used to help refugees escape 'bad' regimes were once framed as heroes. Now the same smugglers were criminalised and accused of bringing in 'illegal' immigrants and 'bogus' asylum seekers. Yet it is clear that genuine asylum seekers are just as likely to have used the services of smugglers. Article 3I of the Geneva Convention acknowledges this reality by stating that states should not impose penalties on account of re- 
fugees' illegal entry or presence. In the new discourse, smuggled migrants are perceived as rational persons (usually economic migrants) who have taken high risks and paid enormous amounts of money to 'criminal organisations' in order to enter a country 'illegally'. They are referred to as 'intruders' who sneak across borders and deliberately break the law. Smuggled migrants are thus also labelled 'illegal' when only their activities are illegal (see Koser 2005 and the introduction to this book).

According to a provision in the Schengen Agreement, human smuggling has become recognised in many European countries' legal systems since the I990s. In the Netherlands, human smuggling entered the penal code on 3I December 1993 (before that date, smuggling of persons was not considered a crime). In 1996 , the minimum penalty for human smuggling was raised from one to four years' imprisonment. In 2005, the profit-making element was removed from the definition of smuggling (it remained intact, however, for assisting 'illegal' stay). This narrowing of the definition of smugglers criminalises more forms of assistance as it classifies all smugglers equally, even the ones who smuggle for 'humanitarian' reasons. Moreover, it explicitly links migration with crime.

\subsection{Methodology}

Salt and Hogarth (2000) brought together data from several studies in order to estimate the number of 'illegal' migrants and the role of smugglers/traffickers within 'illegal' migration. They arrived at the conclusion that most of the data on this topic are unreliable. Moreover, there is believed to be a lot of sensational over-reporting (Black 2003). The academic literature agrees on the fact that many asylum seekers are smuggled, but there are no precise data to back this claim. EfionayiMader, Chimienti, Dahinden and Piguet (200I) say that almost all of their respondents, male as well as female, claimed to have used a smuggler at some stage during their migration to Switzerland. Research in the Netherlands shows that asylum seekers are more frequently smuggled than other immigrant groups who have entered the country in an illegal way (Engbersen, Staring, Van der Leun, De Boom, Van der Heijden \& Cruiff 2002).

Data from the Dutch Immigration and Naturalisation Department (IND) show that in I999, an average of 95 per cent of all asylum applicants were smuggled at some stage of their migration process (IND 2000: 3I). The IND analyses are based on different types of statistical data and also on first and second hearings of asylum seekers after they made their requests. The first hearing of an asylum seeker serves to estab- 
lish his or her identity, nationality and the route he or she has travelled. In the IND analyses, the term 'smuggling' is used when someone has entered the Netherlands without valid travel documents and is assisted by travel agents and has paid a sum of money in return. The term 'travel agent' is used to refer to all the assistance (paid and unpaid) an asylum seeker has had. Hesseling and Taselaar (200I) balance this by presenting a more nuanced picture. Not all people are smuggled from beginning to end, and the quoted 95 per cent of cases are based on the wider definition of a smuggler, namely a travel agent. They also report that the degree to which smugglers are used varies according to ethnic groups. Hesseling and Taselaar (200I) studied three regions in detail: Bosnia and the Federal Republic of Yugoslavia, the Southern Caucasus and the Russian Federation, and Western Africa. They concluded that between io and 60 per cent of the asylum seekers from these regions had been smuggled. They make an important observation, however, regarding the quality of their data, stating that such data cannot be trusted completely as they are based on declarations made by asylum seekers for the purpose of a successful asylum request. It is known that in certain cases, asylum seekers alter parts of their stories in order to improve their chance of securing refugee status.

As far as smuggling is concerned, data from the Dutch Immigration and Naturalisation Department do not provide many details about the routes and modus operandi of their smuggler. Researchers tend to assume that asylum seekers are advised, and often coerced, into not giving smugglers' names or modus operandi to the police. However, concealing them is also in the migrants' own interest. An Eritrean woman explained this as such:

I am not going to tell you the exact name of the mountain where we were hiding; it is a famous place. You might want to know about it, but there are more people to follow, and I do not want to betray them.

I used the life story method as a primary source of data because personal stories reveal what it is like to be smuggled and because spending time with people and showing interest in their experiences makes it easier to collect sensitive information. I focused on three different regions. At the time fieldwork started (in May 2003), asylum applications from Iraq and the Horn of Africa (Somalia, Ethiopia and Eritrea) were among the ten most common in the Netherlands. We interviewed 2I men and three women from Iraq (including one Kurdish man from Iran who lived just across the border with Iraq and a Kurdish woman from Syria). Interviews were in Kurdish, Arabic and Dutch. From the Horn of Africa, we interviewed twelve men and seven women. The in- 
terviewees from the Horn of Africa came from Somalia, Eritrea, Ethiopia and Kenya. Interviews were conducted in Amharic, English and Dutch.

I chose the Soviet Union as my third case because it is known that many people from this region travel out of the country on ordinary visas and enter the Netherlands in semi-legal ways (Engbersen et al. 2002). By including this case, the different types of assistance given to 'illegal' migrants that blur the categories of migrant legality could also be studied. The interviewees from the former Soviet Union came from Ukraine, Russia, Azerbaijan and Chechnya. Eight men and five women were interviewed from this region. Interviews were in Russian, English and Dutch.

For the interviews, I made use of research assistants who had the same geographical backgrounds as the respondents: an Iraqi man (a Kurd), an Ethiopian man and a Georgian woman. Initially, my plan was for them to function as translators, but we found that most of our respondents had had unpleasant experiences with translators during their official asylum hearings. Thus we decided that the assistants would do the interviews on their own in an informal setting. Anonymity and confidentiality were important since human smuggling and 'illegal' migration are sensitive topics. Some people were reluctant to talk about certain aspects or particular details of their migration process, but in general they were very open about their smuggling experience. For them, it had simply been the only way to come to Europe. Many of the interviewees talked about their smugglers as a 'necessary evil'. We tried to create an open atmosphere in which respondents had the opportunity to refuse to answer certain questions or to raise topics they thought to be of relevance. This aspect was something most of the respondents said had been lacking during the asylum interviews with the immigration authorities. In general, we tried to create an atmosphere that was the opposite of the official IND interview setting in which the respondents had previously found themselves.

We avoided interviews with people who were still waiting for a decision on their case, which could have influenced the information given. At the time of the interview, 49 of our 56 respondents had asked for asylum, out of which seventeen were rejected, seven were still in (extended) process, and 25 were granted status (either temporary or permanent). Five interviewees did not apply for refugee status but came to the Netherlands as labour migrants on a visa that was obtained in a fraudulent way. Two respondents were introduced by friends or agencies to a future husband in the Netherlands and applied for a visa through the family reunification procedure in accordance with Dutch immigration policy. 


\subsection{Gendered aspects of 'illegal' migration}

In this chapter I will take a closer look at how smuggling differs in various sending regions: Iraq, the Horn of Africa and the former Soviet Union. Within this I will focus on its gendered aspects. In each case, I will first concentrate on how people's migration options differed by gender and by region. I also will look in detail at different illegal border crossings by analysing a migrant story from each region. What are the specific gender advantages or disadvantages that can be traced through these stories?

\subsubsection{Step-by-step smuggling from Iraq}

Because my research assistant was a Kurd, like many asylum seekers from Iraq, most of the people we interviewed from that country were Kurds. It is very difficult for Kurds in Iraq to get a passport, let alone a visa. Visas are distributed by the Kurdistan Democracy Party (KDP) (in Irbil) and by the Patriotic Union of Kurdistan (PUK) (in Suleimanyia), but there are long waiting lists for these visas (Cornillie \& Declercq 2003). An alternative is to apply for a darnak: a special document for Turks living in Iraq who want to visit Turkey. Two of the people we interviewed were able to get a darnak from their smuggler. It meant they had to pretend to be Turks, which was difficult because they did not speak Turkish. Overall, it is difficult to leave Iraq legally. People often need smugglers not only to enter a country, but also to leave it. When discussing 'illegal' migration, this lack of a legal exit is often ignored. Because of UN sanctions under Saddam Hussein there was no international airport operating in the north of Iraq. People leaving Iraq first had to travel to a neighbouring country before they could continue their journey. Which neighbouring country they chose depended on which part of Iraq they were leaving, the openness of borders, the terrain and the attitude of the authorities. Most people leaving from the north-east area (including Sulemaniya, Ranje and Irbil) cross the IraqiIranian border. Iraqis who want to go to Iran officially need a bargai (permission to stay in Iran) from the Iranian government, but few can get such a permit. Smugglers provide alternatives for those who want (or need) to leave Iraq and cannot enter Iran through the official channels. People leaving from the north-western part of the Kurdish area (Zakhu or Mosul) usually cross into Turkey, which also requires a visa. Some people crossed via Syria, but according to one of our respondents, crossing the Iraqi-Syrian border without being caught is a difficult endeavour: the area is flat and there are few hiding places. There are also Iraqis who use Jordan as a transit country, but this is not perceived as the ideal crossing point among Kurdish migrants because Turkey and Iran are closer, and moreover Kurds prefer to travel over Kurdish land (Chatelard 2002: 7). 
If most asylum seekers are smuggled, this should apply equally to female asylum seekers from Iraq. In I999, 69 per cent of all the Iraqi asylum applications in the Netherlands were from men and 3I per cent from women (IND 2000: II). Unfortunately, it is not clear whether these women came with their partners or by themselves. My Kurdish research assistant was convinced that there were hardly any Iraqi Kurdish women travelling on their own through illegal channels, and therefore interviewed only one woman. I decided to look for Kurdish women from Iraq to interview myself, but this proved difficult. I heard through an organisation for Kurdish women that there were some women who had come to the Netherlands alone, but they did not want to talk about their journey. However I managed to arrange two interviews with Kurdish women, one from Iraq and one from Syria. This does not prove that there are more women who travel on their own, but their stories illustrate what it is like to travel as a woman from this area in an illegal way. It also sheds some light on the gender-specific obstacles and advantages that can be found in this type of border crossing.

\subsubsection{Layla}

Layla $^{2}$ is a highly educated woman who has studied architecture and worked at a technical university in the north of Iraq. At the time of the interview Layla was 3I years old and single. Back in Iraq, she had been involved in politics and was very active at the university, where she organised demonstrations. One day 'Saddam's people' came to Layla's mother's house and threatened her. This was not the first time this had happened: five of her eight children had already had to escape from the country. Layla has brothers and sisters in Germany, Denmark, Sweden and the Netherlands. In I998 she decided to flee, too. The first problem that she encountered was the fact that she did not have a passport and thus could not leave Iraq. Secondly, as a woman and a Sunni Muslim it was difficult to travel alone. Muslim women in other regions must similarly travel with their fathers, uncles or brothers, or at least pretend to do so (Schoorl, Heering, Esveldt, Groenewold, Van den Erf, Bosch, De Valk $\&$ De Bruin 2000: 60). These attitudes towards women restrict their possibilities and shape their migration processes. Still, Layla found a solution for her lack of a passport and the fact that she could not travel alone:

I used the identity card of my cousin to leave Iraq. She lives in central Iraq, so I could travel freely through 'Saddam areas'. I told the driver who was bringing me to the Iranian border that I was going to visit my brother in Iran. If they know you are fleeing as a woman alone, they will not take you. 
If Layla had not invented a brother waiting for her on the other side of the border, the taxi driver would probably not have taken her. In a border village in Iraq Layla met a family who was also fleeing. Layla decided to continue with them because she did not want to travel on her own, and they found a guide who was willing to bring them to Iran for $\$ 400$. It was a deal with a guarantee, which meant they had to pay only upon arrival. Before she left, Layla had asked her mother to sell her engagement jewellery in order to pay for the trip. The group consisted of seven men, four women and two children. They were lucky to have found a guide willing to take them.

There are guides who refuse to take women and children because they slow down the group. I had heard of a route from Turkey to Greece that takes twenty days. Guides refuse to take women and children there because they say that would increase the journey to 40 days. Our guide was used to having women and children in his group. There were six horses with us to carry the women and the children.

By refusing to take women, smugglers obviously limit their options and thus create a gendered difference in migration patterns.

It was November when Layla and the others made the crossing from Iraq to Iran. It had snowed and the paths they took were very icy. Three other factors made this crossing dangerous. First, there was the danger that they could step on landmines left over from the Iraq-Iran war of I980. Second, Layla could have been raped or maltreated by her smuggler. She was lucky that her smuggler treated her well: rape is a gender-specific type of violence that may discourage women from travelling this way. Smuggled men can also become victims of violence, but of a different kind. Thirdly, Layla could have been robbed or sent back to Iraq by the soldiers checking the border area. To avoid being robbed Layla made an extra pocket in her underwear in which she stored a large sum of her own savings and some of the money from other group members. 'In our culture women are not searched easily,' she said. In this regard, she had an advantage over the men who tried to cross borders illegally.

The next stop for Layla was Istanbul. According to Layla, the smuggler had a crush on her and therefore had given her the address of a house where other Iraqis were staying. She would be safe there and would be able to find 'good' smugglers. Layla shared this information with the other travellers. So in Istanbul the whole group stayed in the 'Iraqi' house recommended by the smuggler. From there they planned the next stage of their journey. They found out that it was not safe for men to leave the house because they would run the risk of being 
stopped in the streets. Only Layla and another woman went outside to look for a new smuggler who could take them to a European country. They also bought food and drinks for those who stayed in the house. The women had the advantage of not easily being suspected of being 'illegal' immigrants. Research shows that this is also true on the border between Mexico and the US, where the police are less likely to stop women (Donato \& Peterson 2004).

Eventually Layla and the other woman found a smuggler who knew a truck driver who could take them to Europe. The trip was expensive US \$I,200 - and the contact was risky since there was hardly any information about the man. Not everybody from the original group went along; some decided to take other routes. New people were added to the group. There were 30 people in the truck, hidden behind jeans, and nobody knew where they were going.

It was a long and difficult trip. We had to be quiet. There was very little food and drink, and the most important thing was that there was little oxygen. Before we entered the truck the driver asked explicitly whether there were people with asthma because they would not be allowed to enter the truck. This truck driver also refused children. According to him, they make too much noise.

After spending four days in the truck they were let out at a gas station. There they were put in a taxi and dropped in front of a police station. It was only then that they found out they were in the Netherlands. From the police station they were sent to an asylum seekers' reception centre where they asked for asylum. Layla's involvement in politics was not considered grounds for asylum and she did not get refugee status. This is not uncommon, since women's political activism is often not recognised in the asylum procedure. Women frequently receive status because they are the wives or daughters of male refugees, not because they were politically active themselves (Spijkerboer 2000; Oxford 2005). Layla then applied for humanitarian status (as many more women do than men). At the moment of the interview Layla still did not have status, or any guarantee as to whether she would be able to remain legally in the Netherlands.

The insecurity of her situation has caused Layla serious psychological problems. While in the Netherlands, she married an Iraqi man. Unlike her, he was given refugee status soon after his arrival. According to Layla, this was because he had come to the Netherlands earlier, at a time when Iraqi refugees were accepted more easily. Indeed, admission rules not only vary from country to country, but also from time to time. 
Even though we do not know much about women migrants smuggled from Iraq, Layla's story shows that there are women from that region who do migrate on their own through 'illegal' channels. This is not talked about openly because travelling alone as a Muslim woman is not condoned in general, let alone through 'illegal' means. Interestingly though, Layla's story also shows that while being a woman can be disadvantageous at certain points, it may turn out to be beneficial at others.

\subsubsection{Women travelling on their own from the Horn of Africa}

Most of the people we interviewed from the Horn of Africa first travelled within their region of origin before coming to Europe. It is important to point out that there is a lot of regional migration and that very few of these migrants come to Europe. Most of the people who move within the region stay there. Since we interviewed people in the Netherlands, we were only able to look at the minority of people who continued their journey. Our respondents from the Horn of Africa had first travelled to neighbouring countries such as Ethiopia, Kenya, Sudan, Djibouti and Yemen, and some had also spent time in refugee camps.

One legal migration option besides a refugee camp is resettlement. Access to resettlement differs for men and women. Those refugees who are perceived as being most 'vulnerable' can officially apply, and as a result women and children are resettled more often than men (Horst 2003). Lately, since receiving states have grown reluctant to continue open-ended resettlement programmes for refugees, it has become more difficult for migrants to pursue this option. The resettlement criteria have also become more restrictive. In the late I970s there were over 200,000 resettlement cases a year worldwide, whereas in 2006 there were only 53,8I3. The US used to accept the largest number of refugees by far for resettlement, but after 9/II its resettlement programme was particularly hard hit (UNHCR 2006). As a result of the reduced legal migration options, many asylum seekers turn to alternative possibilities.

At first glance it may seem that the legal option of resettlement and the 'illegal' option of travelling with a smuggler are complete opposites. However, in reality this is not the case. We spoke to people who spent time in a refugee camp and who had already been accepted for resettlement but still decided to contact a smuggler in order to continue their journey. They felt unsafe in the camp and did not want to wait a long time for the final decision on their resettlement. Others did not want to register with the UNHCR because they feared that their claim would be rejected and they would be deported back to their country of origin. 
Some people believe that UNHCR shares information with the authorities in their country of origin. These biased attitudes toward UNHCR are confirmed by a study among Iraqi refugees in Jordan (Chatelard 2002: I2), which states that there are also people who do not want to register with the UN representatives because they want to move to a specific country and therefore plan to seek asylum directly after arriving through 'illegal' channels.

It is a common assumption that men, more often than women, are pioneers who take the initiative and arrange to be smuggled. However, out of the nineteen smuggled interviewees from the Horn of Africa, seven were women. This is not the majority, but still it represents a substantial proportion. These women were the first in their families to come to the Netherlands, leaving their husbands behind. Most of them gave as an explanation for their migration choices the fact that it was safer for them to migrate than to stay behind. This shows that what is considered 'dangerous' and 'safe' can vary from country to country and may even differ according to gender. Danger is also relative: what is seen by some as dangerous migration may be considered less so when the place of departure is already unsafe. The assumption that certain risks are more likely to be taken by young single men does not take into account the fact that the risks of remaining in the country of origin may be higher than those involved in migration (see also the introduction to this book). This example shows clearly that it is important to take into account where people are fleeing from, in order to truly understand the emigration decision-making process. This is particularly interesting from a gender perspective, as women face different risks than men in their country of origin, which leads to different choices regarding migration.

Most of the women we interviewed from the Horn of Africa travelled with their children, whereas men travelled on their own. For instance, Aman, a Somali woman, came to the Netherlands without her husband and with her three children. At the moment of the interview Aman was 43. At age fifteen she was forced to marry a man she had never previously met and who was eight years her senior. They had been together for fifteen years and had five children, one of whom had died during the war. Aman's husband had been working for an underground radio station until he was taken by rebels and imprisoned. Aman did not have any information about where he had been taken. She left Somalia in I994, and until 1997 she knew nothing of her husband's whereabouts.

For Aman, the journey to the Netherlands represents a very emotional phase in her life. This is not only because of the difficulties she faced throughout her journey, but most importantly because it was during the journey that she had lost one of her sons, at the border with 
Kenya. This particular border was a very hectic point, with many migrants making the crossover. Suddenly the police came, and she was arrested and sent back to Mogadishu with only three of her children who were physically closest to her in that chaos. However her son was not walking next to her at the moment of her arrest, and so she lost him. At the moment of our interview she still did not know whether he is alive or not, but fears the worst.

In Mogadishu, Aman and her children were imprisoned by the rebels and she was forced to work for them as a nurse. However her cousins, members of another clan, were also rebels and liberated her and her children from the camp. They brought them to Djibouti, where they also managed to arrange a passport ${ }^{3}$ and a trip to Europe for them. Her cousins had paid the US \$I2,000 necessary for their trip. Aman and her children travelled by plane on somebody else's Djibouti passport, which bore the three children's names. Police call this way of travelling the 'look-alike' method (IAM 2000). There were no problems at the departure or the landing gate. According to Aman, this was because the photo of the passport's original owner was quite similar to hers. The man who provided the passport also accompanied Aman and her children on the plane, and together they travelled via France to the Netherlands. Upon arrival in Paris, the man asked Aman where she wanted to go. She said the Netherlands, because she had a niece there. They then took the Thalys train to the Netherlands.

It was only in the Netherlands that Aman found out about her husband. After having asked almost everybody she knew about his situation, she finally found someone who had seen him at the border between Somalia and Kenya, being helped by people to cross. One day in I997 he called her. She and her children were very happy to know that he was still alive. At that time, Aman had received refugee status and was working twenty hours a week at minimum wage, and thus had trouble merely surviving. In order to bring her husband to the Netherlands she had to meet certain criteria. One of these is a permanent working contract and a certain level of income (I20 per cent of the Dutch minimum wage) in order to support one's spouse. For Aman these requirements were not easy to meet. An alternative would have been to hire a smuggler in order to bring her husband over, but she could not afford that either. Like many other migrant women, she has found it difficult to reunite with her family: at the time of the interview she was still searching for the means to bring her husband to the Netherlands. Studies bear this out, showing that it is more difficult for women than for men to meet the criteria for family reunification (De Boer \& Wijers 2006).

Aman's story reveals that perceptions of safety differ from region to region. From the Horn of Africa it was perceived to be safer for women 
and children to travel to Europe through 'illegal' means rather than stay behind in a region at war. The 'illegal' journey itself was also safer than, for example, the journey of those who came on land from Iraq to Europe. Most of our respondents from the Horn of Africa travelled by plane on forged documents, a relatively safe option.

\subsection{4 'Tourists' from the former Soviet Union}

For our respondents from the former Soviet Union, eight men and five women, it was relatively easy to enter the Netherlands. They either came on a visa obtained with the help of a travel agency or they arranged their journey themselves. The migrants' experiences with obtaining visas from agencies clearly show that it is difficult to make a clear-cut division between legal and 'illegal' forms of migration.

Anna is a 24-year-old Russian woman from Ukraine who entered the Netherlands as a tourist in 2000 . She came to join her boyfriend Boris, who had already been residing and working in the Netherlands for a couple of months. They both planned to work abroad, but because neither had relatives outside Ukraine who could help them migrate they decided to travel as 'tourists'. It should be noted that it is difficult to come up with the correct details of a story to back the application for a tourist visa. It can demand a lot of effort, time and money, and things can go wrong unexpectedly. Moreover, the assumptions of the visa authorities as to whether the applicant is a 'real' tourist are also gendered.

When Anna wanted to join Boris in September 2000, she tried to obtain a visa through the same agency he had used, with the same story to back her application. However, for her, things did not work out as planned.

I decided to go to the same agency Boris had gone to. It was in Kiev. One day I went there with my suitcase, ready to leave. I had already made a reservation for the bus to Germany, for the next day. But when I went to the agency to pick up my passport with the visa in it, hoping it wouldn't be a problem, just as it had not been for Boris, I found out that my visa was rejected! This was a real shock for me. I really did not expect this could happen. I had already quit my job and told everybody that I was leaving for the Netherlands.

The lady at the agency told Anna that she could try again, but Anna did not want to stay in Kiev waiting. The same evening, at her home in Donetsk, she saw an advertisement in the newspaper for an agency that offered German Schengen visas (a Schengen visa is valid through- 
out the whole Schengen zone). Local newspapers in former Soviet countries openly advertise travel visas and job opportunities, and advise readers on the best emigration options to Western Europe. This is the case in many other developing countries (Kuptsch 2006).

The next morning Anna called the agency in Kiev and asked to be sent back her visa application file. In order to apply for the German visa, she needed a short biography stating her marital status, the reason for travelling, and her salary in Ukraine. The rule was that a prospective traveller had to earn at least US \$450 a month. When she applied for the Dutch visa, Anna had brought a false document stating that she worked as a secretary, because her real income (as a teacher) did not meet the minimum level. Boris had done the same, and she thought of using that document again. However, the woman from the travel agency in Donetsk told her that such certificates were not good enough and that she could provide better ones, more believable, at the cost of US \$io each. Anna agreed, and the document showing her income was made before her eyes as she waited.

The woman at the agency looked at Anna doubtfully, noting that she was too young, not to mention unmarried, which would make it more difficult to get a visa. She checked the records of the people she was processing visa applications for in order to find a couple old enough for Anna to pass as their daughter. Thus, the story emerged: Anna was travelling with her parents, the older couple, on whose application form Anna was cross-referenced as a daughter. She also made a copy of Anna's national passport and applied a stamp to it, which stated that she was married. On another page she wrote that Anna had a baby several months old. Being married and having a baby would guarantee her return as far as the embassy authorities were concerned, she explained. Anna could pick up her visa within two weeks. All that she had to do was buy a return ticket to Cologne (in order to prevent any suspicion of overstaying) and finally she could go. From Germany, Anna travelled to the Netherlands on her own. Both Anna and Boris have overstayed their visas, working and living 'illegally' in the Netherlands at the time of the interview.

This example shows that legal migration processes may have illegal components, such as changing one's biography in order to meet the criteria for a tourist visa, or illegal payments for forged documents. In a sense, these travel agencies can also be seen as part of the smuggling industry (Van Liempt 2004). It also shows that travel agencies can take advantage of social gender roles, and that this may have positive outcomes for women's mobility. Apparently it is not expected that women would leave their children behind for a period longer than the three months that a Schengen tourist visa lasts. 


\subsection{5 'Mail-order brides' from the former Soviet Union}

There are more women than men from the former Soviet Union legally residing in the Netherlands. In 2006 the numbers were 27,459 women and 18,542 men. These figures include immigrants and their offspring. The difference in numbers between men and women can be explained by the fact that an increasing number of Dutch men are marrying women from the former Soviet Union (600 in 2003) (De Beer \& Harmsen 2003).

Some of our female respondents from Russia came to the Netherlands with the help of a 'mail-order bride' agency. This is a legal option, but a clearly gendered one; there are no agencies that function as intermediates between Western women and 'mail-order grooms'. Migrating with the help of such an agency implies risks. For instance, women may end up in slavery-like conditions, as some mail-order bride businesses act as facades for trafficking and prostitution. Worried about the possibility of such forms of abuse, the US passed a law in 2005 authorizing consulates to share information with would-be brides regarding their future husbands (UNFPA 2006: 3I). Besides the risk of ending up in slavery-like conditions, foreign women are also dependent on their Dutch husbands for their legal status, which renders them the vulnerable party in the marriage.

\subsubsection{Tamara}

Tamara is a 30-year-old schoolteacher and photojournalist from Moscow. She is divorced and has a son from that marriage. Immediately after her divorce, she started to think about finding a 'good' father for her son. Tamara did not see any opportunities to find a 'good' husband and father for her son in Russia. As she explained:

It is not easy in Russia; all the good men were killed or deported in the Soviet period. The ones left are alcoholics, and they're very conservative.

In 2000 Tamara decided to start searching the Internet for Russian marriage agencies, and registered with one. As she recounted:

I had a lot of responses from Western men. Some of them replied immediately with replies such as, 'Come to my country and I'll be willing to marry you.' I did not buy into these kinds of things. These men just want to get you into their beds. 
Because her mother's best friend from school lives in the Netherlands, Tamara decided to concentrate her search for a husband there. She bought a ticket to the Netherlands and informed the marriage agency of her imminent trip. She had made arrangements to stay with her mother's friend, from whom she had already received an invitation. The agency informed all its male clients in the Netherlands that Tamara was coming.

From that moment on, I started to get more letters from Dutch guys. I fell in love with one of the candidates, Jan. I fell in love with him from his second letter on. He was very romantic. He is 22 years older than I am, but I didn't care. When I would go to the mail order bride agency to check my mail (Tamara did not have an internet connection at home), I always immediately asked for my favourite guy, so everybody knew I liked him the most. And at night we used to talk for four or five hours on the phone, when my son was already in bed.

The agency advised Tamara not to focus on just one person, but it soon became clear that she did not want to see other men.

Jan had been clever enough to pick me up from the airport and to show me the beach, and from the second day on I did not stay at my mother's friend's place any longer, but at his place. Together we cancelled all the other dates I had.

After Tamara went back to Russia, Jan started to visit her and her son in Moscow.

He came almost every month. And one day he suggested that we should come to Holland, so that we could finally all live together.

Tamara and her son travelled on a three-month visa, but before returning to Russia they decided to apply for a residence permit. Jan had a fixed contract as a teacher and could meet the income requirements. He earned enough money to support her. In 200 I Tamara came to the Netherlands with her son to settle. Today, the three of them live together in the Netherlands. Tamara will soon receive her own residence permit.

This example shows that the 'mail order bride' option can be used by women as a strategy to improve their lives despite the risk of ending up as a victim of trafficking. It also demonstrates that migration options differ by country as well as by gender. Besides connecting women 
with possible husbands, mail-order bride agencies also provide women (in this case from the former Soviet Union) with the possibility of travelling in a legal and relatively cheap way.

\subsection{Conclusion}

This analysis of the experiences of women and men who were assisted in the migration process first demonstrates that migrants have different reasons for migrating through 'illegal' channels. Sometimes people choose this route despite the availability of legal options. For instance, it may be quicker or safer to leave a refugee camp through 'illegal' channels than to wait for an official resettlement. The degree of risk in the country of origin may lessen the comparative risks of migration. In times of civil war, for example, it is often safer to move than to stay behind. When looking at differences between regions, it becomes clear that options are not the same across countries and moreover are affected by state policies. Migrants from the former Soviet Union have the opportunity to travel legally, with visas, more than people from the other countries presented here. Those in Iraq and the Horn of Africa find it more difficult to get a visa. This is further complicated by the fact that people in these areas often may not even possess a passport. Thus these migrants are more dependent on smugglers who are able to organise journeys through 'illegal' channels. Most of our respondents from the Horn of Africa travelled with smugglers by plane, using forged, stolen or borrowed documents. This is a relatively safe mode of travel because it gives 'illegal' journeys the appearance of legal ones.

It is also important to note that it is impossible to leave certain countries in a legal way, and that therefore it is not only the policies of the receiving countries, but also those of the sending countries that have an impact on the construction of illegality. Layla's story shows that in order to get out of the northern part of Iraq an exit visa is needed, which is almost impossible to get. This aspect is often overlooked, since the focus of researchers and policymakers lies with the perception of 'illegality' at the receiving end of the migration process.

Moreover, legal and 'illegal' types of migration cannot be separated easily, since what may have started as legal migration can turn easily into 'illegal' migration. For instance, in the case of Anna and Boris, even though they knew beforehand that they wanted to overstay and become 'illegal' residents, they both entered the Netherlands legally as 'tourists'. These forms of assistance are usually not considered in discussions of smuggling. Media images usually show those who enter on shipwrecked boats. This ignores the fact that the majority of 'illegal' 
immigrants actually employ other methods, such as using tourist visas and false documents (see also De Haas 2006).

Besides regional differences, migration opportunities can be different for men and women. Layla's story shows that there are smugglers who refuse to take women and children because they walk too slowly or make too much noise. This limits women's migration options. Tamara's story, in contrast, is a positive example of a gendered migration opportunity. She travelled to the Netherlands as a 'mail-order bride'. This option is available only to women as there are no 'mail-order grooms'. The roles ascribed to women by society may also have an impact on how they move. It was shown that in Iraq, it is not perceived as fitting for women to travel on their own. Layla had to pretend she was visiting an uncle in order to find a man who would drive her to the Iranian border. Furthermore, upon arrival her asylum story about political resistance was not acknowledged as a credible claim. This situation connects with the fact that women are more often considered victims in the migration discourse than active agents. The narrative of victimhood has lead to protective measures, which do not always help but can restrict women's options and expose them to greater danger (see also the introduction to this book).

However, it was also shown that women can actively make use of these gendered perceptions and opportunities. Anna's story shows that a single woman with no children is more easily suspected of overstaying a visa and thus becoming an 'illegal' immigrant, as compared with a married mother who leaves her children behind. Both Anna and the woman working at the travel agency actively used these gender perceptions. Layla also benefited to a certain extent from the fact that the smuggler had a crush on her. However, this could also have had negative effects. Some women are afraid to travel with a smuggler because of the danger of being sexually abused. These gender-specific dangers do exist and should not be denied. Yet at the same time it is important to acknowledge the complexities involved in assisted forms of migration and the different levels of agency that are at play.

\section{Notes}

I I would like to thank Linnet Taylor for editing this chapter and I gratefully acknowledge the useful comments of the editors of the book as well as the anonymous referees.

2 A pseudonym is used here to guarantee anonymity.

3 Since I991, no official Somali passports have been issued, which means no one can get a visa to travel abroad. As a result there is a lively trade in forged and stolen passports. 


\section{References}

Anderson, B. \& J. O'Connell Davidson (2006), 'The trouble with trafficking', in C. van den Anker \& J. Doomernik (eds.) Trafficking and women's rights, II-26. London: Palgrave.

Andrijasevic, R. (2004), Trafficking in women and the politics of mobility in Europe. PhD thesis. Department of Women's Studies. Utrecht: University of Utrecht.

Aronowitz, A. (200I), 'Smuggling and trafficking in human beings: The phenomenon, the markets that drive it and the organisations that promote it', European Journal on Criminal Policy and Research (2): I63-195.

Berger, J. \& J. Mohr (I975), A seventh man: migrant workers in Europe. Harmondsworth: Penguin.

Black, R. (2003), "Breaking the convention: Researching the "illegal" migration of refugees to Europe', Antipode 35(I): 34-54.

Chatelard, G. (2002), Jordan as a transit country: Semi-protectionist immigration policies and their effects on Iraqi forced migrants, New Issues in Refugee Research, Working Paper no 6I.

Cornillie, B. \& H. Declercq (2003), In de schaduw van Saddam: Het Koerdisch experiment in Irak. Amsterdam: Bulaaq.

De Beer, J. \& C. Harmsen (2003), 'Eén op de drie huwelijken heeft een buitenlands tintje', Demos, bulletin over bevolking en samenleving I9 (I7): 54-56.

De Boer, M. \& M. Wijers (2006), Taking women's rights seriously? An examination of the fourth report by the government of The Netherlands on implementation of the UN Convention on the Elimination of all Forms of Discrimination against Women (CEDAW), 20002004. Utrecht: Humanist Committee on Human Rights (HOM).

De Genova, N. P. (2002), 'Migrant "illegality" and deportability in everyday life', Annual Review of Anthropology 31: 4I9-447.

De Haas, H. (2006), Trans-Saharan migration to North Africa and the EU: historical roots and current trends, Migration Information Source, November.

Doezema, J. (2002), 'Who gets to choose? Coercion, consent and the UN Trafficking Protocol', Gender and Development Io (I): 20-27.

Donato, K.M. \& E. Peterson (2004), 'Women and men on the move: Undocumented border crossing', in J. Durand \& D. S. Massey (eds.), Crossing the border: Research from the Mexican Migration Project, III-I3O. New York: Russell Sage Foundation.

Doomernik, J. (200I), 'Tussen daar en hier: Van werving tot smokkel', Tijdschrift voor Criminologie 43 (4): 7-13.

Efionayi-Mader, D., M. Chimienti, J. Dahinden \& E. Piguet (200I), Asyldestination Europa: Eine Geographie der Asylbewegungen. Zurich: Seismo.

Engbersen, G., R. Staring, J. van der Leun, J. de Boom, P. van der Heijden \& M. Cruijff (2002), Illegale vreemdelingen in Nederland: Omvang, overkomst, verblijf en uitzetting. Rotterdam: RISBO Contractresearch BV.

Hesseling, R. \& A. Taselaar (200I), 'Asielmigratie en mensensmokkel', Tijdschrift voor criminologie 32: 340-349.

Horst, C. (2003), Transnational nomads: How Somalis cope with refugee life in the Dadaab camps of Kenya. Phd thesis. Faculteit der Maatschappij- en Gedragswetenschappen. Amsterdam: University of Amsterdam.

IAM (2002), Mensensmokkel in beeld. Zeist: Informatie- en Analysecentrum Mensensmokkel en Landelijk Parket Rotterdam.

IND (2000), Smokkelbeeld. Gegevens over smokkel van asielzoekers uit de tien belangrijkste herkomstlanden in 1999. The Hague: Immigration and Naturalisation Department (IND). 
Kleemans, E., E. van den Berg \& H. van de Bunt (I998), Monitor georganiseerde criminaliteit. The Hague: Wetenschappelijk onderzoeks- en documentatiecentrum (WODC).

Koser, K, (2005), Irregular migration, state security and human security: Paper prepared for the Policy Analysis and Research Programme of the Global Commission on International Migration, September.

Kuptsch, C. (2006), Merchants of labour. Geneva: International Labour Office (ILO).

Morrison, J \& B. Crosland (2000), 'The trafficking and smuggling of refugees: The end game in European asylum policy'. New issues in refugee research, Working paper no. 39. Geneva: UNHCR.

NRM (2007), Mensenhandel: Vijfde rapportage van de Nationaal Rapporteur. The Hague: Bureau NRM.

Oxford, C.G (2005), 'Protectors and victims in the gender regime of asylum', NWSA Journal I7 (3 Fall): I8-38.

Salt, J. \& J. Stein (I997), 'Migration as a business: The case of trafficking', International Migration 35: 467-489.

Salt, J. \& J. Hogarth (2000), 'Migrant trafficking and human smuggling in Europe: A review of the evidence', in F. Laczko \& D. Thompson (eds.), Migrant trafficking and human smuggling in Europe, a review of the evidence with case studies from Hungary, Poland and Ukraine, II-I64. Geneva: IOM.

Schoorl, J., L. Heering, I. Esveldt, G. Groenewold, R. van den Erf, A. Bosch, H. de Valk \& B. de Bruin (2000), Push and pull factors of international migration: A comparative report. Luxembourg: EUROSTAT.

Soudijn, M. (2006), Chinese human smuggling in transit. The Hague: Boom Juridische Uitgevers.

Spijkerboer, T. (2000), Gender and refugee status. Aldershot: Ashgate.

Staring, R., G. Engbersen, H. Moerland, N. de Lange, D. Verburg, E. Vermeulen \& A. Weltevrede (2005), De sociale organisatie van mensensmokkel. Zeist: Kerkebosch BV.

UNHCR (2006), Refugees by numbers. 2006 edition. Geneva: UNHCR.

UNFPA (2006), State of world population 2006: A passage to hope. Women and international migration. New York: United Nations Population Fund.

Van Dijk, E. (2002), Mensenhandel in Nederland 1997-2000. Zoetermeer: KLPD.

Van Hear, N. \& K. Koser (2005), 'Asylum migration: Implications for countries of origin', in G. Borjas \& J. Crisp (eds.), Poverty, International migration and asylum, I2I-42. Basingstoke: Palgrave Macmillan/United Nations University/World Institute for Development Economics Research.

Van Liempt, I. (2004), 'De sociale organisatie van mensensmokkel: Het beeld van mensensmokkel als grootschalige georganiseerde misdaad genuanceerd', in P. Mascini \& N. Doornbos (eds.) Onbekend terrein. Grenzen van het vreemdelingenbeleid, 38-6I. Boekuitgave Amsterdams Sociologisch Tijdschrift, 3I (3).

Van Liempt, I. (2006), 'Trafficking in human beings: Conceptual dilemmas', in C. van den Anker \& J. Doomernik (eds.) Trafficking and women's rights, 27-42. London: Palgrave.

Van Liempt, I. (2007), Navigating borders: Inside perspectives on the process of human smuggling into the Netherlands. Amsterdam: Amsterdam University Press (AUP).

Van Schendel, W. \& A. Itty (2005), Illicit flows and criminal things: States, borders and the other side of globalization. Bloomington: Indiana University Press. 



\title{
5 Old and new labour migration to Malaysia: From colonial times to the present ${ }^{1}$
}

\author{
Blanca Garcés-Mascareñas
}

Anyone visiting Malaysia from the I880s onwards would be struck by the presence of foreign workers in the country. At the end of the nineteenth century and the beginning of the twentieth a visitor could observe Chinese workers in tin mines and Indian workers at sugar, coffee and later rubber plantations. Indian workers also constructed roads and railways and worked in supporting public services. Most of these Chinese and Indian workers were men. One hundred years later, from the I980 onwards, a visitor would again find many foreign workers. This time, however, these workers mainly come from Indonesia as well as Nepal, India, Myanmar, Vietnam and Bangladesh. As in the past, male foreign workers are prominent at plantations and construction sites. However, in contrast to the past, female foreign workers are found in manufacturing and domestic service.

If we compare past and present, many similarities become apparent. To mention a few, foreign workers in Malaysia have always taken up jobs that were rejected by local workers. Moreover, they have been associated with temporary labour. Many Chinese, Indian and Indonesian workers have returned to their countries of origin after some years. Their stay in Malaysia has thus been shaped by their desire to save as much money as possible in the shortest period of time. In this regard, their lives are not much different from those of Spanish, Italian, Turkish or Moroccan guest workers who came to Western Europe during the I950s and I96os. In the case of Malaysian foreign workers, however, their dependence on employers has been increased and institutionalised by specific contracts, debts and work permits. Furthermore, in contrast to European guest workers, their recruitment has always been organised by private agencies.

By comparing old and new labour migration in Malaysia, this chapter has three objectives. First of all, it aims to explain present migration policies. In particular, by relating the present to the past, my purpose is to understand why Malaysian migration policies have tried to create a temporary labour force, why they have tied foreign workers to particular employers and how private recruitment agencies have organised the immigration process (to and from Malaysia) from the beginning. Secondly, this chapter aims to show how the rigidities underlying mi- 
gration policies have tended to make non-regulated migration an advantage both in colonial and present times. Since these rigidities might be different for women and men, I will examine to what extent and how the specific position of female migrants determines other forms of non-regulation. Thirdly and finally, the analysis of migration flows outside the state-regulated migrant system will enable me to distinguish between different meanings of non-regulation. In particular, a distinction can be made between non-regulation, illegality and deportable illegality. ${ }^{2}$ Here again I will consider to what extent the implications of being illegal are different for women and men. The final goal of this research is to link illegality to the nature of the state and therefore to denaturalise the concept of illegality and insist on its historical specificity.

This research is based on secondary literature as well as on data obtained from my fieldwork in Kuala Lumpur from June to November 2006. Since the comparison between old and new labour migration in Malaysia arises from the need to explain and relate the present situation to the past, the historical part is exclusively based on secondary literature. Regarding my research on labour migration to Malaysia from the I980s onwards, one of the main difficulties I encountered was that migration policies in Malaysia are considered confidential. As a member of the Cabinet Committee for Foreign Workers stated, 'Migration policies are somewhere in the Ministry of Home Affairs but they are confidential, they are not accessible to the public' (interview 20/10/2006, Putrajaya). I therefore focused on the press as the main source of analysis. More specifically, I went through the Malaysian newspapers The New Straits Times, Bernana Times, New Sunday Times, The Malay Mail and Malaysiakini from 1985 to 2006. Moreover, I conducted about 30 interviews with representatives of employers' organisations and trade unions, government officials, recruitment agents and members of NGOs.

In this chapter I will first explain why foreign workers have been so fundamental to the Malaysian economy since colonial times. I will then analyse the main characteristics and practices of state-regulated labour migration. In the following section I will examine migration flows outside regulated labour migration and highlight how these have been promoted by migration regulations. Finally, I will consider the various means of non-regulated migration from colonial times to the present. In the conclusion, I will make some theoretical observations to position this chapter within the whole book as well as in relation to the paradigm of historical migration studies. 


\subsection{Exporting goods, importing labour}

In the early nineteenth century, before the British came into control (direct or indirect) of the Malay States, the family functioned as the basic unit of the economy, which was based on rice production, horticulture and fishing. In the late nineteenth and early twentieth centuries, the British developed rubber and tin industries in contrast to the previous subsistence economy. These so called 'twin' pillars of the colonial economy were meant to serve the growing demands of US and British commercial and industrial interests (especially for war material). Within the next few decades, colonial Malaya became a producer and exporter of primary products and an importer of manufactured goods (Kaur I999: 8; Chin 1998: 34). A foreign-owned export-oriented sector emerged that ran parallel to the subsistence, peasant agricultural sector represented by local Malays and that was directly linked to the British metropolis.

In the I89os government officials concluded that the Malay States had not attracted more British capital because labour was difficult to mobilise (Parmer I960: 18). The colonial government blamed its inability to attract local Malays either on the Malays' laziness (Emerson I964: I8) or on their value system, which, the British argued, discouraged the pursuit of individual gain (Silcock I965: I83). Most likely, Malays were economically self-sufficient in the communal (village) settings, so there was no need for them to work under the strenuous conditions, strict discipline and regulations demanded by waged employment in mines and plantations (Ramachandran I994: 42). Unable to attract local Malays to support the colonial economy, the British turned to migrant labour from China and India.

In the late nineteenth and early twentieth centuries, mainly Chinese labourers worked in the Malaysian mines and plantations. In I9II Chinese workers represented 96.2 per cent of the total mining labour force (Kaur I999: 8-9). To neutralise the threat posed by an overconcentration of Chinese workers, the colonial administration consciously sponsored East Indian (Tamil) immigration into the then rapidly expanding rubber plantation sector (Halim I982 26I). This led to a clear predominance of Indian labour in the plantations. Indians also worked on the construction of roads, railways and public utilities services. In 1940 the Chinese represented 34.2 per cent and Indians Io per cent of the total population of Malaya (see Table 5.I). The proportion of women in the total migration flow has been estimated at less than 20 per cent (Sandhu I969: 82). 
Table 5.1 Population of Malaya, 1911-1944 (total numbers and percentages)

\begin{tabular}{lrrrr}
\hline Origin & \multicolumn{1}{c}{1911} & \multicolumn{1}{c}{1921} & \multicolumn{1}{c}{1931} & \multicolumn{1}{c}{1940} \\
\hline Malays and other Malaysians & $1,416,796$ & $1,651,051$ & $1,962,021$ & $2,286,459$ \\
& $(52.1)$ & $(48.8)$ & $(44.4)$ & $(41.5)$ \\
Chinese & 915,883 & $1,174,777$ & $1,709,392$ & $2,358,335$ \\
& $(34.2)$ & $(35.2)$ & $(39.2)$ & $(42.8)$ \\
Indians & 267,159 & 471,666 & 624,009 & 748,829 \\
& $(10.0)$ & $(14.2)$ & $(14.3)$ & $(13.6)$ \\
Others & 72,916 & 60,560 & 89,924 & 112,471 \\
& $(3.7)$ & $(1.8)$ & $(2.1)$ & $(2.1)$ \\
Total & $2,672,754$ & $3,358,054$ & $4,385,346$ & $5,504,094$ \\
\hline
\end{tabular}

Source: Sandhu 1969: 275

After independence in I957, the Malaysian economy continued to be based primarily on commodity exports under the control of foreign corporations. In terms of the migrant presence, the main difference was that those workers who had been foreigners became recognised citizens of the new nation-state and hence settled permanently in the country. Moreover, in the mid-I96os the switch from traditional rubber plantations to palm oil and cocoa production (less labour intensive) reduced the demand for labour. In the I960s these changes created a temporary labour surplus that generated migration flows from the old to the new plantations and to urban areas (Navamukundan I988: 2I7). However, this labour surplus represented only a short interlude in a country characterised by large labour shortages.

In the early I970s the economic inequalities between the Malays and the Chinese, and the related growing conflict within and between them, led the Malaysian government to implement the New Economic Policy (NEP I97I-I990), which was designed to eliminate poverty and to restructure society by dismantling the identification of ethnicity with economic function and geographic space. The NEP marked the transition from unregulated to planned capitalism and led to unprecedented economic growth characterised by the shift from a reliance primarily on commodity exports to exports in manufactured goods. For instance, while agriculture and other raw materials decreased from 50 per cent in I970 to II.3 per cent of the total national exports in I990, manufactured goods increased from 6.5 per cent to 54.2 per cent in the same period (Chin 1998: 57). This economic shift was facilitated by foreign capital and the relocation of production plants from Western to developing countries (Froebel, Kreye \& Heinrichs 1980, quoted in Chin I997: 358), together with the rise of commodity and oil prices (Chin 2000: I043).

The NEP had contradictory effects in the country's labour market. On the one hand, the emphasis on urbanisation and industrialisation 
promoted Malays to a better position in the labour market. For instance, while Malays represented 30.8 per cent and 37.9 per cent respectively of the total labour force in the secondary and tertiary sector in I970, after the NEP these percentages increased to 48.0 and 51.0 per cent (Chin I998: 56). On the other hand, unlike in South Korea and Taiwan, economic growth depended on foreign investments that were attracted by emphasising the low labour costs (Jomo 2003: 203). In short, while urbanisation and employment policies sought to and did improve the socio-economic position of Malaysian citizens regardless of their ethnicity, economic growth continued to be dependent on a continuing supply of cheap labour. In this context, the employment of both legal and illegal migrant workers from neighbouring countries was quickly perceived as necessary for economic growth and prosperity.

Despite the state's attempt to reduce the migrant worker population and its increasing emphasis on high-tech and less labour-intensive industries, in the last two decades there has been an unabated increase in the inflow of migrant workers. In I995 there were about I.2 million foreign workers (of which 500-700,000 were estimated to be illegally in the country) and in 2000 there were about 2 million (I.2 million legal and about 800,000 illegal) (Jones 2000: 54; Wong \& Anwar 2003: I72). In 2006 the number of legal foreign workers reached I.8 million plus an estimated one million illegal workers (Syed \& Syed 2006). Legal foreign workers are mainly found in manufacturing, plantations, domestic services and construction (see Table 5.2). Most of them come from Indonesia, but there are also foreign workers from Nepal, India, Myanmar, Vietnam, Bangladesh, the Philippines and Pakistan (see Table 5.3).

Table 5.2 Documented foreign workers in Malaysia by economic sector ( $x$ 1,000)

\begin{tabular}{lccccrr}
\hline Year & Agriculture & Manufacturing & Mining & Construction & Services & Total \\
\hline 1991 & 126.5 & 38.9 & 1.9 & 42.1 & 86.2 & 295.6 \\
1992 & 137.2 & 54.1 & 2.3 & 59.1 & 96.5 & 349.2 \\
1993 & 176.1 & 103.9 & 2.1 & 51.4 & 107.5 & 441.0 \\
1994 & 179.5 & 109.8 & 2.0 & 58.1 & 110.9 & 460.3 \\
1995 & 173.0 & 115.7 & 1.8 & 64.8 & 124.0 & 479.3 \\
1996 & 271.6 & 264.8 & 3.5 & 131.2 & 229.0 & 900.1 \\
1997 & 265.2 & 283.0 & 6.1 & 150.1 & 240.9 & 945.3 \\
1998 & 317.6 & 250.1 & 2.6 & 151.4 & 278.0 & 999.7 \\
1999 & 363.6 & 250.6 & 6.0 & 131.1 & 301.9 & $1,053.7$ \\
2000 & 415.4 & 262.5 & 2.9 & 163.5 & 326.7 & $1,171.0$ \\
2001 & 281.4 & 213.0 & 2.1 & 99.0 & 265.6 & 861.1 \\
$2006 *$ & 412.0 & 614.0 & n.a. & 101.0 & 160.0 & $1,800.0$ \\
\hline
\end{tabular}

Source: Ministry of Finance (2005)

* Data obtained from The New Straits Times 19 July 2006 
Despite growing demand for female foreign workers in sectors such as manufacturing and domestic service, women continue to be underrepresented in comparison with the number of male foreign workers. In I994 it was estimated that female foreign workers represented 29 per cent of the total number of foreign workers in the country (Kassim I994: 5). However, it is difficult to break down data according to gender as official statistics and reports do not provide this information. While official reports distinguish the proportion of foreign workers in domestic service - in June 2006 workers in domestic service represented 17.5 per cent of the total number of foreign workers (The New Straits Times 8 September 2006) - the percentage of women in manufacturing and service remain unrecorded.

Table 5.3 Distribution of foreign workers by country of origin

\begin{tabular}{|c|c|c|c|c|c|c|c|}
\hline Country & 1997 & 1998 & 1999 & 2000 & 2001 & 2002 & $2006 *$ \\
\hline Indonesia & 50.4 & 53.3 & 65.7 & 69.4 & 68.4 & 64.7 & 67.5 \\
\hline Bangladesh & 39.4 & 37.1 & 27.0 & 24.6 & 17.1 & 9.7 & 3.2 \\
\hline India & 3.1 & 3.6 & 3.2 & 3.0 & 4.0 & 4.6 & 7.7 \\
\hline Myanmar & 2.2 & 1.3 & 0.9 & 0.5 & 1.0 & 3.3 & 5.1 \\
\hline Thailand & 0.5 & 0.7 & 0.5 & 0.4 & 0.4 & 2.4 & 0.4 \\
\hline Philippines & 2.7 & 2.7 & 1.8 & 1.2 & 1.0 & 0.8 & 1.2 \\
\hline Pakistan & 1.7 & 1.0 & 0.6 & 0.5 & 0.4 & 0.2 & 0.8 \\
\hline Nepal & 0.0 & 0.1 & 0.1 & 0.1 & 7.3 & 9.7 & 11.1 \\
\hline Others & 0.0 & 0.2 & 0.2 & 0.3 & 0.4 & 4.6 & 5.5 \\
\hline
\end{tabular}

Source: Ministry of Finance (2005)

* Data obtained from The New Straits Times 19 July 2006

\subsection{State-regulated migration}

Both in colonial times and in the present migration, regulations in Malaysia have aimed to create a cheap foreign labour force. This has been done by enforcing labour circulation, restricting labour mobility and maintaining the powerlessness of the migrant. In this section, I will analyse each of these aspects in colonial times and at present. Since Chinese migration to Malaysia during colonial times was not regulated by the government, I will refer exclusively to Indian labour migration.

\subsubsection{Labour circulation}

Both in colonial times and in the late twentieth century, labour migrants were young individuals without dependents. The main difference is that while in the colonial period most of them were men, from the I980s onwards there were both men and women. All of them, however, came to Malaysia for a limited period of time. Their aim was 
to make money and return to their country of origin after some years. This viewpoint was also held by officials. Both British and Malaysian authorities saw migrant workers as sojourners who could be repatriated when the demand for their services no longer existed. In this regard, the supply of labour increased when they were needed and decreased during recessions. Examples are the mass repatriation programmes organised by the government after the economic depressions of 1929 and 1997.

Although in both cases the temporality of foreign workers functioned as a regulatory mechanism to soften the impact of economic crises, it was different in each case. Indian workers came to colonial Malaya with an initial contract of three to five years as indentured labour (Arasaratnam I979: II) or with an invitation letter to work for a particular employer under the kangany system. Although they arrived as temporary migrants, their stay in Malaysia could last as long as they were needed. They were only expected to return in case of unemployment or health problems. At the same time, since the predominantly single male migrant population in Malaysia was seen as a potential threat to social stability and public order, various attempts were made by the colonial government to encourage entire Indian families to migrate.

Female migration was thus seen as a way of ensuring the stability of the Indian migrant community and providing a constant supply of low-wage labour. Although they were invited to colonial Malaya as wives and mothers, women were also expected to work, since Indian men's wages could not support a family. In this regard, colonial policy constructed dual roles for Indian women in Malaya. On the one hand, they reproduced the future low-wage workforce and ensured stable environments for Indian men. On the other hand, they worked alongside men on the plantations (Chin 1998: 37). As a result of this policy, the percentage of Indian women living on plantations for I9II, I92I and I93I increased from 26.I per cent to 35.I per cent and 39.9 per cent respectively (Chin I998: 37). The main consequence was that many of these families settled in colonial Malaya. At the time of independence in I957, Indian Malaysians represented II.I per cent of the total population.

Since the early I990s foreign workers have come to Malaysia on short-term contracts that could be extended for a maximum period of five to seven years. As most of my informants pointed out, this is because 'they are foreign workers, but not migrants' or 'they came here to work, not to get permanent residence permits' (interviews of I3 September 2006 and 20 October 2006 , Kuala Lumpur). In other words, the temporality of new migrants has been a strategy not only to reduce social security costs, but also to prevent the incorporation of the mi- 
grants into Malaysian society. These new restrictions on the temporality of migrant workers have had a huge impact on the position of female migrants. In order to avoid costs for families and health care and to keep foreign workers from settling in the country, female foreign workers are obliged to undergo annual gynaecological tests. If they are found to be pregnant they are immediately deported. This means that in contrast to the past, foreign women are only welcome as workers.

Their position in the labour market (mainly as domestic workers), however, continues to emphasise their reproductive role. In other words, although they are not allowed to have children, their work is still seen as unproductive and reproductive at the same time. As was said by a representative of Malaysian employers, 'they are not normal workers, they are part of the family'. Although this perception is not unusual (Schrover, Van der Leun \& Quispel 2007), it is nonetheless striking if we take into account that their presence is fundamental for economic growth as it permits and sustains the participation of Malaysian women in the more productive sectors of the economy and reduces political pressure on the state elite to provide public childcare centres or to encourage Malaysian employers' patronage of privately owned childcare (Chin I998: I09; Chin I997: 329).

Since they are perceived as family members and non-workers, domestic workers are the only foreign workers who are allowed to stay in Malaysia for longer than seven years. According to the government guidelines for foreign domestic workers, they can renew their work permit until they are 45 years old. However, as many interviewees told me, in practice they can stay in Malaysia as long as they are required since their birth certificates can easily be forged. Hence domestic workers are the only foreign workers who can stay in Malaysia almost indefinitely. This does not mean that they get a permanent residence permit. As explained by an agent for domestic workers, 'The government is not obliged to give you a permanent residence permit. It depends on what you have done. What is your contribution to the nation as a maid? I don't see any reason to give them a permanent residence permit. That is for engineers' (interview of I6 September 2006, Kuala Lumpur). In other words, domestic workers, in contrast to other foreign workers, can be 'temporary' migrants forever in Malaysia.

\subsubsection{Labour immobility}

In both the past and the present, restricted labour mobility in the labour market has been achieved by tying the worker to a particular employer. Indentured workers were paid in advance for the passage to Malaysia and signed a contract that obliged them to work for a particular employer until they had paid off their debt. Under the kangany system, 
the labourers were no longer expected to sign a contract, but they were again expected to pay back the cost of their passage with wages earned after arrival. In this regard, although they were free workers, they continued to be tied to a particular employer (Jackson I96r: I24). This situation was resolved in I9IO by the introduction of the Indian Immigration Fund, set up by the colonial government and based on a levy imposed on a per capita basis on all planters who used Indian labour. Its purpose was to provide free passage for labourers to Malaysia. ${ }^{3}$ However, the cost of living on the plantations was often higher than their income and therefore many of them continued to be deeply indebted to their employers (Netto I96r: 46).

Since the beginning of the I990s the mobility of foreign workers has been limited by work permit conditions and debts (Garcés-Mascareñas 2006). First of all, work permits do not allow foreign workers to change employers. If a foreign worker seeks a better job, he or she immediately becomes 'illegal'. Secondly, debts (recruitment costs) continue to tie workers to their current employers. This is particularly the case for domestic workers and Indonesian workers in general. Although this practice is not allowed, it is tolerated by the authorities. As observed by a recruitment agent, 'If recruitment agencies don't cover their trip to Malaysia, who will do it? Who is going to bring the maid here? Who is going to pay for all the initial costs?' (interview of 26 September 2006 , Kuala Lumpur). Apart from recruitment costs, other expenses such as an annual insurance and levy increase the initial debt.

The main effect is not only that foreign workers are tied by contract to a particular employer, but also that the termination of their contracts depends on the advance payment of such expenses. As observed by the representative of a trade union, 'Because employers advance the costs, they consider that they have the right of ownership' (interview of 9 October 2006, Kuala Lumpur). In order to prevent workers from 'running away' or 'absconding', employers usually hold foreign workers' passports. Since it is widely believed that domestic workers 'run away easily', many recruitment agents and even government officials suggest that employers not give them a weekly day off.

\subsubsection{Powerless position}

Besides their status as non-citizens, the powerlessness of foreign workers is part and parcel of the two aspects mentioned before, that is, their temporality and their restricted mobility. Regular migrants in particular have to accept the terms and conditions of their contracts since their labour rights are restricted and they do not have the freedom to move from job to job. 
In recent years, the immobilisation of foreign workers has been criticised by most Malaysian and international NGOs. Although foreign workers are protected under the Employment Act, their reliance on a particular employer prevents them from going to the labour or industrial courts. In particular, the Immigration Act clearly states that a foreign worker is only allowed to be employed and stay in the country within the premises of the enterprise as stated on the work permit. If the migrant worker wants to discontinue his or her employment due to abuse or exploitative working conditions or if the employer cancels the work permit, the foreign worker has to return to the country of origin. Sometimes a special pass is issued if the case is taken to court, but this pass has to be renewed monthly and does not give permission to work. Since court cases can take months or even years, this means that in practice most foreign workers are forced to return home before the end of the trial (Tenaganita 2005: 26-34).

Regarded as family members and non-workers, domestic workers are not included in the Employment Act and there is no minimum wage or regulation of working conditions. In this regard, their powerlessness vis-à-vis their employers is even greater. What can they do if they are not paid, if they have to work twenty hours a day, do not have a day off as stipulated by their contracts or if they are paid much less than previously promised? In practice, as many of my informants told me, they have few legal means to change their situation.

\subsection{Managing the labour migrant system}

One of the major characteristics of labour migration to Malaysia and South-East Asia in general has been the privatisation and commercialisation of recruitment. Again this applies to the past and the present. Most old and new foreign workers have come to Malaysia through a recruitment agent, who went to the countryside in India, Indonesia, Nepal or Bangladesh to look for prospective migrants, offer them a job on behalf of a particular employer and organise the trip to Malaysia. In contrast to European guest worker programmes, where recruitment was mainly directly organised by employers, the whole recruitment process has been determined by the presence of these middlemen whose business depended on the number of migrant workers they were able to send to Malaysia.

Under the indentured labour system, the usual procedure followed by employers to obtain Indian labour was to place orders for workers with certain recruiting firms in Southern India. These firms would contact a professional recruiter, who could use "his greater knowledge of the world and of the need for labour in lands abroad to induce his 
less sophisticated countrymen to emigrate' (Parmer I960: I7). Apart from recruiting expenses and the labourer's passage, both the recruiting firm and the professional recruiter charged a fee per worker sent to Malaysia. These fees not only represented extra costs for the employer (and later on for the migrant worker), but also induced many abuses in order to increase the number of recruited workers. In this regard, a contractor reported to an enquiry commission in I908:

I was sent over to India in I886 to recruit coolies for the government, and from the experiences then gained I can confidently assert that not one single coolie who leaves India knows the real value of the rupee in this country, nor the cost of living here. The recruiters are scoundrels to a man; they not only make gross misrepresentations to the intending emigrants, but even employ force to bring them over. (quoted in Netto I96I: 24)

Under the kangany system, the recruiter worked for Malay employers and was sent to India to recruit labour from his own village. Officially, the kangany had to restrict his recruiting to relatives and friends and could only leave his village with the recruited labourer after getting the consent of the village's headman. This system presented two major advantages for employers. First of all, it broke the monopoly of the Indian recruiting firms, who were believed to have restricted labour supply and increased recruitment costs. Secondly, the commissions paid under the kangany system were much lower since, unlike the profits paid to professional recruiters, they fluctuated less with the demand for labour (Ramachandran I994: 59). Although it was thought that the kangany system would reduce some of the abuses mentioned above, in the I920s and I930s many critics argued that kanganies used bribery to stimulate workers to migrate, forged the signatures of village headmen, promised young people a guaranteed good future, exploited family quarrels to induce people to migrate and gave false information about wages and living conditions in Malaysia (Parmer I960: 58; Sandhu I969: I00). As Mohapatra (2007) has described, a distinction can be made between the relatively free recruitment phase and repression after arrival on the plantation.

Since the I980s, recruitment agencies have reappeared on the migration scene. In fact, one of the first measures to regulate labour migration was an act introduced in I98I to allow the establishment of legal recruitment agencies for foreign workers. Since then regular migration flows into Malaysia have been characterised by the presence of a huge network of intermediaries: the sub-agent who recruits the workers in the countryside, the agent who organises the trip to Malaysia, the agent in Malaysia who receives the workers at the airport and the 
sub-agent who brings the agent in Kuala Lumpur in touch with the employer somewhere else. All these agents increase the costs of migration. As mentioned before, the migrant worker pays them either before coming to Malaysia or from his or her first wages after arriving in Malaysia. As in the past, apart from the extra costs that such a system implies, the commercialisation of the recruitment process has led to abuse. For instance, promises before departure do not correspond to working and wage conditions in Malaysia. Formal employers (according to the work permit pass) do not exist and hence foreign workers become illegal, or agencies process one-month or three-month visas instead of the required two-year visa in order to get the workers into Malaysia as fast as possible (see Rudnick 1996; Jones 2000; Wong \& Anwar 2003; Tenaganita 2006).

\subsection{Beyond state-regulated migration}

In both the colonial period and at present, migration to Malaysia has not been limited to state-regulated migration. Besides Indian labour, Chinese workers also came to colonial Malaya. They started coming even before Indian workers did, and their presence has been just as significant (see Table 5.I). However, the government of Malaya had limited knowledge about Chinese labour and their community in Malaya and little control over them (Beeman 1985: I4I). In recent decades, in addition to government regulated migration, illegal migration has also been an important channel of labour migration to Malaysia. Although it is impossible to assess the number of illegal migrants in the country, it has been estimated that by the mid-I980s there were over 500,000 illegal migrants and by the mid-I99os close to one million (Liow 2004: I4; Chin 2002: 2I). In 2006, after new and more refined migration policies to regulate labour migration to Malaysia and reduce illegal migration were introduced, the number of illegal migrants was estimated to be more than one million (Syed \& Syed 2006). The population of illegal migrants consists mainly of Indonesians, but migrants from other Asian countries are also found. Some of them have come to Malaysia illegally and some of them later became illegal while in Malaysia.

On the basis of Beeman's work (I985), Wong and Anwar (2003: 2I72I8) observe striking similarities when comparing old Chinese migration with current illegal migration to Malaysia. First of all, Chinese labour migration to colonial Malaya is comparable to illegal migration in its spontaneous character. Although agents played an important role in the transportation and job placement of Chinese in the past and illegal migrants today, in both cases most migrants paid their own passage to 
Malaysia and the whole migrant experience was organised by their own social networks. Secondly, partially as a consequence of the impact of social networks, both Chinese and illegal migrants were mainly recruited locally by local employers. The main effect was a high rate of job mobility and a greater capacity (in comparison with migrant workers within the migrant labour system) to negotiate their work and wage conditions (see also Kassim I995).

In colonial times Chinese migrants stayed much longer than their Indian migrant contemporaries since they were not repatriated as part of unemployment policy (Beeman i985: 154). Moreover, Chinese wages were consistently and significantly higher than the wages of the Indian migrants. Whereas the wages of Chinese workers tended to reflect the conditions of the market, the regulated supply of Indian labour kept the Indians' wages low (Beeman I985: 266). This difference in wages should also be explained by the fact that alternatives beyond estate labour were much more open to the Chinese. For instance, while from I9II to I93I between 55.9 and 65.0 per cent of the Indian working population found employment on plantations, by I92I less than 20 per cent of the working Chinese population were employed in the mining sector and by I93I about 25 per cent were employed as plantation labourers (Beeman I985: 29-30).

At present, illegality seems to be an advantage to the migrant worker as having a legal status might increase rather than diminish the exploitation of foreign workers by their employers (Kassim I995). This is a common conclusion drawn by many Malaysian scholars (Kassim I993a: 5-6, I993b: 6, I994: 3-4, I995: 7, I996: 2; Hugo I995: 277; Ruppert 1999: 33; Bagoes Mantra I999: 63; Pillai 2000: I42; Jones 2000; Battistella 2002: 363; Wong \& Anwar 2003: I92-198). Three main reasons are given. First of all, illegal migration permits an escape from the long and cumbersome official procedures needed for entering Malaysia. Secondly, illegal migration cuts down the costs of migration since exit, entry and renewal taxes and fees are avoided. Thirdly, once in Malaysia the illegal migrant is not bound to a particular employer and a specific job. Illegal migration is thus faster, cheaper and less constrained than legal migration to Malaysia.

At this point it is worthwhile to refer to some more specific situations. Kassim (I995: I2-I5) gives two examples that illustrate the difference between legal and illegal migrants. The first example refers to domestic workers. Most legal domestic workers live with their employers. In many cases, they do not have any days off and they work much longer than stipulated in their contracts. At the end of the month, they are paid a fixed salary that in most cases does not correspond to the hours they have been working. In contrast, many illegal domestic workers do not live with their employers. Instead they live in rented ac- 
commodation in cheap neighbourhoods such as the squatter areas. They work for six or eight households, they are paid per hour and they can rest at night and in the weekends. The second example refers to legal factory workers. They are tied to their employers and cannot negotiate or improve their wages and working conditions, while illegal workers at petrol pumps, restaurants and construction sites seem to enjoy better conditions. Their salaries are higher, they have more contact with people outside the workplace and they can leave for better employment (for instance in sectors with large labour shortages) whenever they want (Kassim I995: I2-I5).

Given these differences and the impossibility to improve their labour situation by legal means, many legal foreign workers decide to become illegal by leaving their employers. This is what in the Malaysian newspapers is described daily as cases of 'absconding' or 'running away'. Although there are no data on the total number of absconding cases, it seems that this is a common phenomenon. For instance, in 1997 an immigration official declared in a Malaysian newspaper that most illegal migrants at the new international airport had run away from plantations in search of better wages (The Malay Mail, I2 June 1997). A member of the Malaysian Palm Oil Plantation observed similarly that plantation workers 'easily' run away as soon as they have a friend in the construction sector (interview of 2I September 2006, Kuala Lumpur).

Data on cases of 'running away' refer exclusively to domestic workers. In 2005 , out of a total of about 300,000 foreign domestic workers, 19,406 cases of running away were reported to the Immigration Department (New Sunday Times, 2 July 2006). However, the real number of cases of running away might be much higher. As a representative of an employer organisation observed, many employers do not notify the police when their workers escape from their workplace since it implies losing their security bond (interview of 2I September 2006, Kuala Lumpur). Many agents and politicians explain the phenomenon of absconding among domestic workers by arguing that they 'easily fall in love' or they are 'easily manipulated'. If we go back to our comparative historical perspective, we immediately realise that this was also a common practice among Indian workers. From I9I2 to I922, for instance, almost one third of the total Indian workers deserted plantations. They were mainly men and, in contrast to the present, no employer argued that they were in love or had been manipulated.

Probably the point on which the female domestic workers of today are most similar to the Indian workers in the past is in their powerless position. In both cases, as Beeman (1985: 173) argued regarding Indian workers in the late nineteenth and early twentieth centuries, since they do not have any means of bargaining, 'running away' or 'absconding' 
might be a way to improve the situation. This practice is not very different from the ordinary everyday means of resistance used by Malaysian peasants (like boycotting the introduction of combine harvesters or the killing of animals), as described by James Scott in his famous book Weapons of the Weak (1985). In both cases resistance against the state, employers or landowners is rooted in everyday material goals rather than in a revolutionary consciousness. In contrast to common definitions of resistance, these practices are not collective and organised, nor are they principled and selfless. However, by absconding or running away from their employers, foreign workers and particularly domestic workers might improve their working conditions while disrupting production and increasing the general costs of recruitment.

\subsection{Meanings of non-regulation}

Chinese migration to colonial Malaya was not planned or directed by the colonial authorities. However, non-regulation did not mean illegality, as labour migration to Malaya was not restricted until the I930s. In other words, Chinese migrants could migrate to and move within colonial Malaya without much control. Indian migrants who had escaped from plantations did not become illegal either. In fact, with the end of indentured servitude, foreign workers were in principle free to leave and choose an employer who offered a higher wage or better working conditions. Although employers asked for their immobilisation, colonial authorities were very reluctant to comply. As stated by a colonial officer in I9I5, 'I think it would be a retrograde step if we passed a clause which would interfere with the freedom of the labourer. [...] We should have no indentured labour, and I would prefer myself to go the other way, and that is to tell the labourer he is not tied for a month and can go off any day' (quoted in Parmer I960: I49). In contrast to the present, absconding was thus not associated with illegality.

In the I930s labour migration to Malaysia was restricted for the first time. In I933 and I938 a monthly quota was introduced for male and female Chinese workers respectively to limit their entry 'in accordance with the political, social and economic needs for the moment of the various administrators of Malaya' (quoted in Blythe I947: I02). Moreover, in I938 the Indian government banned assisted Indian emigration to Malaya. In this case, the ban was imposed to respond to the demands of Indian nationalists. After independence in 1957, one of the first pieces of legislation passed by the new nation-state was an Immigration Act (I959), which regulated the entry and movement of non-citizens in Malaysian territory. It was followed by an Employment Restriction Act (I968), which made access to the labour market for non- 
citizens contingent upon possession of a work permit. As Wong has observed, the institution of the new nation-state was thus made legally coterminous with that of a closed labour market. Citizenship conferred both the right of residence in a nationally defined territory and the right of unhindered entry to the labour market. Non-citizens were barred from both (Wong 2002: 4).

Although this legislation referred to citizenship, ethnicity also played a role in the implementation of these policies. In particular, the presence of thousands of illegal Indonesians working in rubber and oil palm plantations and on construction sites did not attract much public attention, as they were perceived to be similar to Malays. This border became more blurred, however, when most illegal Indonesian migrants received a permanent status within two or three years, some even within months, and thus became legal residents. Some of them obtained these documents legally, others illegally (see Pillai 2006). The main result of this selective border permeability was that most Indonesians who arrived before the late I980s could settle in Malaysia. This had a second effect: their children could obtain Malaysian citizenship and, in consequence, qualify as Malays under the so called Bumiputera policy, which gives indigenous people (particularly Malays) privileged rights by virtue of their historical attachments.

However, as Indonesian migrants started to move to urban areas and particularly to those economic sectors reserved for local workers, they were seen as competing with these workers in the labour market and particularly as challenging the re-distribution of wealth and employment among the different ethnic groups. For instance, in the mid- and late I980s petty Malay traders in the major cities protested heavily against illegal Indonesian workers, as they feared economic displacement. Moreover, non-Malay communities accused the state of turning a blind eye to the inflow of Indonesian migrants and hence increasing the Malay portion of the overall population (due to the ethnic similarities between Indonesians and Malays). Although Dorall (1989) argues that ethnic politics correlate with migration policies, this should be more nuanced since the main importers (including recruiting agencies) and employers of foreign workers, particularly the Chinese, have been non-Malay (Kassim I997: 23). The reaction to illegal (Indonesian) migration in the late ig8os should thus be understood not only in ethnic terms, but also - and above all - from a social-class perspective: it was the Chinese low urban class (mainly represented by the Democratic Action Party) who, like low-class Malays, felt threatened by their presence.

The need to protect the national labour market finally displaced ethnicity as a component of the implementation of migration policies and therefore placed citizenship as the unquestioned threshold to the free 
entry to the labour market. This gradual closure of Malaysian borders led to the state-regulated labour migration as described above and gradually changed the position of the illegal migrant. Since then, illegal migrants have been stripped of all rights. This shift towards a 'deportable illegality' should be explained in relation to two parallel processes. First of all, illegal migrants started to be seen as a threat to the social and economic stability of the country. In particular, there were increasing concerns about their impact on crime, housing, health care and the labour market. As observed by Chin (2002: 33), the main issue is that such negative representations have become a key management strategy in identifying migrant workers' as 'outsiders' or foreigners whose movement in society must be kept under surveillance, if not overtly contained.

Secondly, through amendments to the Immigration Act and highly publicised deportation campaigns the new contours of illegality have been defined. Under the amended Immigration Act (2002), illegal migrants can be sentenced to mandatory jail terms for up to five years, receive up to six strokes of the cane and be fined up to RM Io,000. At the same time, widely publicised detention and deportation campaigns or the so-called 'crack-downs on illegal aliens' have sought to reduce the number of illegal migrants. Since 2004 the People's Volunteer Corps (Ikatan Relawan Rakyat Malaysia, known as Rela) assists the police in arresting and detaining illegal migrants. Their participation in detention campaigns has aroused concern among non-governmental and human rights organisations. Physical and mental abuse in detention camps has also been denounced. For instance, in August 1995 the non-governmental organisation Tenaganita reported 'abuse, torture and dehumanised treatment of migrant workers in detention camps' (Tenaganita 1995). In I997 Amnesty International reported that from I992 to 1997, 7I illegal migrants died in detention camps in Malaysia (Amnesty International 1997).

Further research is needed to see whether the even more powerless position of female foreign workers and their extended though 'temporary' permits create other incidences or other forms of 'deportable illegality'. Although I do not have conclusive data on this issue, I would like to advance three possible hypotheses. First of all, domestic workers are the only foreign workers who have not been 'repatriated' to their countries of origin in periods of economic downturn. In this regard, their central role within Malaysian families and within the Malaysian economy in general may have prevented them from being as likely to be deported as other foreign workers. Secondly, as the presence of many domestic workers is exclusively limited to the private sphere of the household, in practice they may be less likely to be detained. In other words, since migration enforcement takes place in public space, and since it is 
therefore in the public realm that illegality is ascribed both to regular and illegal workers, it may be easier for foreign domestic workers to escape apprehension. Thirdly and finally, while they may be less likely to be deported and detained, they may suffer more easily from exploitation and abuse since they are often confined within the walls of Malaysian families.

\subsection{Conclusion}

On the question whether labour migration in South-East Asia during the nineteenth century and the first half of the twentieth was free or unfree migration, McKeown (2004) and Mohapatra (2007) disagree. According to McKeown, most migrants were free and moved through personal networks of family and friends. In contrast, Mohapatra argues that most migrants moved in systems of debt and to destinations where they were controlled by employers and forced to accept low wages and bad working conditions. My own analysis seems to suggest that their degree of freedom depends on specific circumstances. While Indian migration was regulated by the state and their presence in Malaya depended on their employers, Chinese migrated without much control and were able to move from job to job and negotiate their work and wage conditions. In this regard, the starting point of this discussion should be that labour migration in South-East Asia was not a unique and homogeneous phenomenon, but rather consisted of two different realities characterised by different kinds of state intervention.

By comparing old and new labour migration, we can also see that differences persist into the present. As I showed in this chapter, legal migrants face constraints similar to those confronted by the earlier Indian migrants. Their migration is regulated by the state and therefore their presence is restricted to particular economic sectors and tied to a particular employer for a limited period of time. In contrast, illegal migrants - like old Chinese migrants - are free to change their jobs and can stay in Malaysia even in face of economic downturn, illness or pregnancy. In this regard, as in the past, the situation of labour immigrants in Malaysia is not homogeneous. However, in contrast to the past, non-regulated labour migration has become illegal and subsequently an object of sanction, detention and expulsion. That is what I called deportable illegality.

This shift in the meaning of non-regulated migration results from the new borders imposed by the nation-state. In particular, the rise of the nation-state has brought with it a new dilemma: while labour migration is necessary for economic growth, it challenges the social and political bases of the new Malaysian nation-state. For instance, labour 
migration is seen as a threat to the position of local workers in the labour market, to the ethnic balance between Malay, Chinese and Indians and, in the last years, to national security. The main result, as in many other countries, has been the gradual exclusion of the migrant: while the presence of legal migrants has been increasingly regulated and limited, illegal migrants have become an object of detention and deportation.

When we link illegality to the nature of the state, the question is no longer how illegal migration occurs, but rather how it is produced by the state and its migration policies. In this regard, we could conclude that, in contrast to what many scholars assume, the 'illegal' can only be understood as part or a product of particular contexts (see the introduction to this volume). As pointed out by De Genova, illegality is 'mutually constituted by particular migrations within the respective immigration regimes of specific nation-states' (2002: 424). When analysing illegality, we should thus start with the questions of how migrants are or become illegal and what the exact meanings and implications are of illegality. In short, any research demands a detailed analysis of the legal production of illegality. This means examining not only how laws and policies produce illegal migration, but also how they construct it differently depending on various classifications such as gender, ethnicity and class.

\section{Notes}

I This research was financed by the Agencia Española de Cooperación Internacional (AECI) and the Netherlands Organisation for Scientific Research (NWO). I would like to thank Pieter C. Emmer, Melody Lu Chia Wen, Sandra Ezquerra and the editors of this book for their comments on this chapter. I am particularly thankful to Aimee Rindoks for her English language revision and comments.

2 In my PhD thesis I distinguish between non-regulation, irregularity and illegality. I use the term 'irregularity' to refer to migrants without proper documentation and the term 'illegality' when irregularity is perceived as a threat and irregular migrants are excluded from the normal limits of the law and the state.

\section{References}

Amnesty International (1997), AI Report: 1997. www.amnesty.org/ailib/aireport/ar97/ ASA28.htm.

Arasaratnam, S. (1979), Indian in Malaysia and Singapore. Kuala Lumpur: Oxford University Press.

Bagoes Mantra, I. (I999), 'Illegal Indonesian labour movement from Lombok to Malaysia', Asia Pacific Viewpoint 40 (I): 59-68. 
Battistella, G. (2002), 'Unauthorized migrants as global workers in the ASEAN Region', Southeast Asian Studies 40 (3): 350-37I.

Beeman, M.A. (1985), The migrant labour system: The case of Malaysian rubber workers. $\mathrm{PhD}$ thesis. Chicago: University of Illinois.

Blythe, W.L. (I947), 'Historical sketch of Chinese labour in Malaya', Journal of the Malayan Branch of the Royal Asiatic Society 20 (2): 64-II4.

Burawoy, M. (1976), 'The functions and reproduction of migrant labour: Comparative material from Southern Africa and the United States', ASJ 8I (5): I050-I087.

Chin, C.B.N. (I997), 'Walls of silence and late twentieth century representations of the foreign female domestic workers: the case of Filipina and Indonesian female servants in Malaysia', International Migration Review 3I (2): 353-385.

Chin, C. (1998), In service and servitude: Foreign female domestic workers and the Malaysian 'modernity' project. New York: Columbia University Press.

Chin, C. (2000), 'The state of the state in globalization: Social order and economic restructuring in Malaysia', Third World Quarterly (2I) 6: I035-I057.

Chin, C. (2002), "The "host" state and the "guest" worker in Malaysia: Public management of migrant labour in times of economic prosperity and crisis', Asia Pacific Business Review 8 (4): I9-40.

De Genova, N. P. (2002), 'Migrant "illegality" and deportability in everyday life', Annual Review of Anthropology 31: 4I9-447.

Dorall, R. (I989), 'Foreign workers in Malaysia: Issues and implications of recent illegal economic migrants from the Malay world', in Asian Pacific and Development Center, The trade in domestic helpers: Causes, mechanisms and consequences. Kuala Lumpur: Asian and Pacific Development Centre.

Emerson, R. (I964), Malaysia: A study in direct and indirect rule. Kuala Lumpur: University of Malaya Press.

Garcés-Mascareñas, B. (2004), The creation of temporary labour schemes: A comparison between guestworker programs in the United States, Western Germany, Malaysia and Kuwait. Master's thesis. Amsterdam: Amsterdam University.

Garcés-Mascareñas, B. (2006), 'Produciendo "ilegales”: Políticas de inmigración en Malasia', Revista Española de Investigaciones Sociológicas iı6: 259-270.

Halim, F. (1982), 'Capital labour and the state: The West Malaysian case', Journal of Contemporary Asia I2 (3): 259-80.

Hugo, G. (I995), 'Labour export from Indonesia: An overview', ASEAN Economic Bulletin I2 (2): $275-298$.

Jackson, J.C. (I96I), Planters and speculators: Chinese and European agricultural enterprise in Malaysia, 1876-1921. Kuala Lumpur: University of Malaya Press.

Jomo, K.S. (2003), 'Growth with equity in East Asia', in K.S. Jomo (ed.), Southeast Asian Paper tigers? From miracle to debacle and beyond, 96-219. London: Routledge Curzon.

Jones, S. (2000), Making money off migrants: The Indonesian exodus to Malaysia. Hong Kong: Centre for Asia Pacific Social Transformation Studies.

Kanapathy, V. (2004), 'International migration and labour market developments in Asia: Economic recovery, the labour market and migrant workers in Malaysia'. Paper prepared for the Workshop on International Migration and Labour Markets in Asia.

Kassim, Azizah (I993a), 'Immigrant workers in Malaysia: Issues, problems and prospects', in B.H. Lee \& S. Oorjitham (eds.), Malaysia and Singapore: Experiences in industrialisation and urban development, I24-162. Faculty of Arts and Social Sciences: University of Malaya.

Kassim, Azizah (I993b), 'The registered and the illegals: Indonesian immigrants in Malaysia'. Paper presented at the seminar on movement of peoples in Southeast Asia organised by PMB-LIPI, Jakarta, Indonesia, I7-I9 February. 
Kassim, Azizah (I994), 'Within and beyond the kitchen: The experience of female immigrant workers in Malaysia'. Paper submitted to the Conference on linking our histories: Asian and Pacific women as migrants, September 30-October 2, University of Melbourne, Australia.

Kassim, Azizah (I995), 'Foreign workers in Malaysia: an analysis of sanctioned bondage'. Paper presented at the regional conference of the international council of psychologists on 'psychological issues in a growing global community', I0-I2 August, Manila.

Kassim, Azizah (1996), 'Labour Migration in ASEAN: Issues and problems from the Malaysian perspective'. Paper presented at the 7th Southeast Asia Forum, 3-6 March, organised by ASEAN-ISIS, Kuala Lumpur.

Kassim, Azizah (I997), 'Management of foreign labour: A Malaysian experiment'. Paper presented at the 2nd Asia Pacific Conference of Sociology, I8-20 September, University of Malaya.

Kaur, A. (I999), Women's work: Gender and labour relations in Malaysia. Amsterdam: Working Papers on Asian Labour.

Kaur, A. (2004), 'Mobility, labour mobilisation and border controls: Indonesian labour migration to Malaysia since I990'. Paper presented at the I5th Biennial Conference of the Asian Studies Association of Australia in Canberra, 29 June-2 July.

Liow, J.C. (2004), 'Malaysia's approach to its illegal Indonesian migrant labour problem: Securitization, politics or catharsis?' in IDSS-Ford workshop on non-traditional security in Asia, Singapore, 3-4 September.

Lucassen, L. (2007), 'Migration and world history: Reaching a new frontier', International Review of Social History 52 (I): 89-96.

McKeown, Adam (2004), 'Global migration, I846-I940', Journal of World History I5 (2): I55-189.

Mill, J. Stuart (I909), Principles of political economy: With some of their applications to social philosophy. London: Longmans.

Ministry of Finance (2005), Economic Report 2004/2005. Kuala Lumpur: Malaysia National Printers Berhad.

Mohapatra, Prabhu (2007), 'Eurocentrism, forced labour and global migration: A critical assessment', International Review of Social History 52 (I): IIO-II5.

Navamukundan, A. (I988), 'Labour shortage in plantations: A trade union view', Current issues in labour migration in Malaysia, Kuala Lumpur: Faculty of Economics and Administration, University of Malaya.

Netto, G. (I961), Indians in Malaya: Historical facts and figures. Singapore: Netto.

Parmer, J.N. (I960), Colonial labour policy and administration: A history of labour in the rubber plantation industry in Malaya. C. 1880-41. New York: JJ Austin.

Pillai, P. (2000), 'Labour market developments and international migration in Malaysia', in Migration and the Labour Market in Asia: Prospects to the year 2000, I37-I49. Paris: OECD.

Pillai, P.N.A. (2006), Indonesian labour immigrants in Malaysia: A case study of Kampung Sungai Kayu Ara, Selango. Kuala Lumpur: PhD thesis. Institut Pengajian Siswazah. Universiti Malaya.

Rajaram, Prem Kumar \& Carl Grundy-Warr (2007), Borderscapes: Hidden geographies and politics at territory's edge. Minneapolis: University of Minnesota Press.

Ramachandran, S. (I994), Indian plantation labour in Malaysia. Kuala Lumpur: S. Abdul Majeed for INSAN.

Rudnick, A. (1996), Foreign labour in Malaysia manufacturing: Bangladeshi workers in the textile industry. Kuala Lumpur: INSAN.

Ruppert, E. (I999), 'Managing foreign labour in Singapore and Malaysia: Are there lessons for GCC countries', Washington, DC: World Bank. 
Sandhu, K.S. (1969), Indians in Malaya: Some aspects of their immigration and settlement. Cambridge: Cambridge University Press.

Schrover, M., J. van der Leun \& C. Quispel (2007), 'Niches, labour market segregation, ethnicity and gender', Journal of Ethnic and Migration Studies 33 (4): 529-540.

Scott, J.C. (I985) Weapons of the weak: Everyday forms of peasant resistance. New Haven: Yale University Press.

Silcock, T.H. (1965), 'The effects of industrialisation on race relations in Malaysia', in Guy Hunter (ed.), Industrialisation and race relations, I77-I99. Oxford: Oxford University Press.

Syed, Muhamud \& Sharir Bin Syed (2006), 'Protection of migrant and refugee rights in Malaysia'. Paper presented at the Conference on the Challenges of Global Migration and Forced Displacement, I-2 August, Kuala Lumpur.

Tenaganita (I995), 'Memorandum on abuse, torture and dehumanised treatment of workers at detention camps', Kuala Lumpur: Tenaganita.

Tenaganita (2006), Migrant workers: Access denied. Kuala Lumpur: Tenaganita.

Wong, D. (2002), 'The national context of migration research in Malaysia: Which nation, what state, whose migration', Osnabruck.

Wong, D.T \& T. Afrizal Teuku Anwar (2003), 'Migran Gelap: Irregular migrants in Malaysia's shadow economy', in G. Battistella, \& M.B. Asis, Unauthorised migration in Southeast Asia, I69-227. Manila: Scalabrini Migration Centre. 


\title{
6 The romantic appeal of illegal migration: Gender, masculinity and human smuggling from Pakistan'
}

\author{
Ali Nobil Ahmad
}

Despite the growing prominence of gender within the field of migration studies (testified to by this volume and many others), there exists an unmistakeable scarcity of empirical research dealing with the construction and performance of masculinities in the process of international migration. Apart from a handful of notable exceptions (e.g. Charsley 2005; Gallo 2006) the critical study of men represents something of a lacuna in an otherwise burgeoning literature. This is partly due to the fact that scholars are understandably preoccupied with new forms of female agency in a world where the 'lone male bread-winning migrant' is increasingly seen to be an ideological distortion or a thing of the past (Morokvasic-Müller, Erel \& Shinozaki 2003: 9; Pessar \& Mahler 2003: 822). Whatever the broader realities behind the apparent feminisation of international labour flows, however, some sending contexts are still characterised by vast discrepancies in power between the sexes which continue to structure the gendered makeup of independent out-migration. Indeed, the rising tide of restrictionist legislation in Europe to curb legal entry options is making family reunification more difficult, a fact which in turn appears to be reinforcing the maleness of migratory flows from some parts of the world, in terms of both the ratios of men to women who compose those flows and the kinds of ideologies in which they become entrenched.

Labour flows from (and indeed within) Pakistan, for instance, remain almost exclusively male, suggesting that, within some migration systems at least, understanding masculinity and male agency is likely to be of considerable importance in making sense of why migration occurs.

The forces that drive such all-male migratory configurations cannot be explained by recourse to mainstream migration theories on social networks and kinship alone, particularly whilst historians and social scientists deploy these in a manner that is largely gender-blind and economistic. Building upon feminist critiques of these theories and the concepts upon which they are based (Agarwal 1997; Phizacklea 2003), this chapter interrogates the oft assumed status of the household as a 
homogenous income-pooling unit and the primary force behind emigration decisions, and explores the role of alternative spheres in which decisions to migrate are fostered. A key concern is to break open the analytical dichotomy between 'economic' and 'cultural' push factors behind labour migration, along with unhelpful assumptions about the nature of migrant rationality that characterise typical explanations of decision-making. Discussion is restricted to the sending context, and accords special attention to illegal forms of migration and the issue of human smuggling, since the role of masculine subjectivity is especially visible in the agential forces that drive them. Migration, it will be shown, is imbued with a male ideology of travel which thrives off exchanges of information within all male networks. This ideology has been further masculinised by restrictionist migration policies and the resulting difficulty of family-reunification, which have made travel abroad ever more expensive, risky, attractive to youth and inaccessible to women of all backgrounds.

\subsection{Theoretical framework}

Mainstream theories of migration have undergone considerable revision in recent years, with mid-level units replacing the abstract individual and structural forces that, respectively, dominated neoclassical economics and Marxist theories of migration in the first three quarters of the twentieth century (Hoerder 1997). Whilst scholars of migration have always taken a keen interest in 'chain migration', more importance than ever is currently being attributed to social networks in generating migration, facilitating the spread of information on labour market opportunities and driving the migration process. Summarising the present state of affairs, a leading theorist of migration recently wrote, 'The importance of social networks for migration can hardly be overstated' (Arango 2004: 28). Foner (2001: 3-4) has claimed that migration itself can be conceptualised as a process of 'network building'. Tilly has gone as far as stating that it is not individuals but networks that migrate, which should therefore be the primary unit of analysis in migration (1990: 84).

Related to this unprecedented prominence of social networks in migration theory is the pivotal role of kinship and the household, which, following Becker (I976) and other proponents of 'social choice theory' (Agarwal 1997), are frequently stressed as the most powerful driving forces of international migration from the developing world. Anthropologies of migration from Pakistan and South Asia to the United Kingdom are good examples of this tendency, as they emphasise the centrality of household, family and clan to the virtual exclusion of the 
individual (Dahya 1974; Khan 1977; Ballard \& Ballard I977; Shaw I994, 2000). Though it is seldom stated explicitly, motivation is often presumed to be driven by unexamined 'economic' forces that are taken to be exclusively 'rational' in that migration is invariably portrayed as the product of consciously calculated strategies designed to reduce risk and facilitate commercial gain for the household. Shaw's (2000: I3) study of Pakistanis in Oxford, typically, states that 'the primary motive for migration from Pakistan to Britain in the late I950s and early I960s was socio-economic' without explaining what this means. Foner, in the introduction to an influential volume, states categorically that networks 'reduce the risks of migration' (200I: 3-4). Many historical accounts of migration are similarly economistic, despite the existence of important exceptions (e.g. Henkes 200I). Gabaccia, for instance, argues that Latin patriarchy ('international family economies') developed out of 'rational, shrewd choices' based purely on the fact that there were work options for women at home (Gabaccia 2001: 203). 'Separation,' she suggests, 'made economic sense' (ibid.: 195-I97). Where historians of migration do touch on 'socio-cultural' issues, these get mentioned in passing before the author inevitably falls back on economic reductionism (e.g. Delaney 200I: 2I7).

Such accounts tend to overlook the contexts in which networks other than those involving kin drive and facilitate migration. Ties of association located outside the household and commercial networks, both of which are important in the context of illegal migration from Pakistan, are barely mentioned in their representation of the migration process. Such links, which do not necessarily reduce the risks of migration, are unexplored because they do not fit in with the dominant, largely benign portrayal of migration networks that currently prevails. The quality of the information transmitted through networks is unexamined in existing literature; the opacity of the objectives of actors within the network is left unanalysed or treated as irrelevant. Only rarely is it mentioned that various kinds of migration networks are predominantly or exclusively made up of men, which, as Van Liempt (this volume) points out, sometimes actively exclude women and children. Indeed, the gendered particularity of networks, institutions, economic culture and individual actors within households is often simply overlooked in studies of migration (Phizacklea 2003: 83-86).

This chapter seeks to give gender its due centrality in the study of Pakistani migration networks. It does so by abandoning the exclusive preoccupation with mid-level units preached by many exponents of social network theory in the conviction that excessive stress on ties between migrants on the move can lead to neglect of the very agential forces and motivations that drive movement in the first place. Above all, it scrutinises the ties between migrants and other units such as the 
household and the family through an analysis of individual testimonies. The framework is thus integrative and focuses on the multi-level interaction of the micro-level (individual motivations and experiences) with processes that take place at the meso-level (social relations and ties between two or more individuals) and macro level (the role of the state). As will be seen, such an approach facilitates examination of social networks in a manner that takes into account those realms of human experience, such as gender and sexuality, which cannot be easily compartmentalised as either 'cultural' or 'economic'.

\subsection{Methodology}

The empirical material presented here is based upon research conducted between 2003 and 2006 in London, Italy and Pakistan. A small number of in-depth interviews in Pakistan were conducted during a short research visit of three weeks with immigration officers and state officials from the Overseas Pakistanis Foundation (three), journalists (one), NGO employees and social workers (two), smugglers (one), migrant sending households (two), internal migrants (four) and prospective smuggled migrants who had been deported or apprehended during previous failed attempts to reach Europe (three). Local and national press sources were also consulted and anthropological participant observation was conducted in travel agents, bazaars and town centres in both Lahore and Islamabad.

My main source of data, however, consists of 60 life stories narrated in Urdu by Pakistani migrants from Punjab, NWFP (North-West Frontier Province) and Mirpur. This qualitative material can be divided into three data sets, each of which is based on the testimonies of twenty respondents. The first cohort is made up of 'old' migrants: middle-aged or senior British citizens who migrated to Britain between 1960 and I980. Of these, the testimonies of ten men who migrated mostly legally as young adults in their twenties, interviewed in their London homes, are of particular interest in this chapter. Of the second cohort, all but two are men currently in their twenties and thirties who migrated to Britain between I99I and 2004 (the other two are women, who migrated as dependents). These 'new migrants' were interviewed at work or in nearby cafes. The Italian cohort was composed entirely of men between the ages twenty and 54, interviewed in Florence and Prato, all but one of whom had first left Pakistan in their twenties and thirties (the average age of emigration was in fact 26 ). These men were interviewed in their workplaces, cafés and other public spaces.

Given the diversity of ages, classes and marital backgrounds of migrants at the time of emigration, some of the arguments advanced in 
this article are unlikely to be uniformly applicable. Those relating to youthful subversion and sexual adventure, for instance, barely affect married émigrés in their thirties and beyond. Others, such as the pervasive influence of consumerism, apply universally. Others still, such as the appeal of travel, apply to some more than others. In view of this diversity, it is important to bear in mind that the general masculine ideology sanctioning pursuit of selfhood and transgression that I highlight encompasses broad strata of men in different ways.

Particular kinds of sensitivity were required to broach issues of sexuality and illegality with elder men, in whose presence I was expected to be respectful and deferential as a younger person. For this reason, I was not always able to probe them extensively on certain topics; the suggestion that they migrated for anything other than self-betterment and to sacrifice their own happiness for their families was controversial and potentially offensive. Equally, to ask old and new migrants about lawbreaking they have been involved in was problematic for obvious reasons. Lengthy processes of trust-building and the adoption of a flexible approach was thus necessary; questions could not be posed mechanically in the same order to all respondents as part of a rigid sociological questionnaire. Interviews were semi-structured and took differing formats and lengths. Half were tape-recorded; the remainder were simultaneously translated and transcribed in note form.

Only ten interviewees were women. These were all within the London cohorts. Unlike the men, many of whom had experienced some form of illegality (particularly recent arrivals), none of the women entered illegally. Indeed, I did not hear of women being smuggled from Pakistan to the West except in very exceptional cases. This was to be expected: the vast majority of persons smuggled into Europe from Pakistan are male. A more serious problem lies in the absence of interviews with female (or indeed male) family members of smuggled migrants. This was unavoidable due to my positionality as a young, single male of Pakistani origin and due to the fact that the research was conducted primarily in destination countries. This particular shortcoming threatened to reproduce, in my research, a key weakness of many existing studies of masculinity: 'internalism' - the abstraction of men's identities and relations from those of women, a tendency which has turned much of men's studies into a field that, perversely, occludes women and obscures men's dominant relations with and over them (Ditz 2004: I7).

The antidote to internalism is juxtaposing men's experiences with women wherever possible, so that the respective experiences of the sexes develop in parallel rather than in dialogue. In research such as my own, which suffers from an absence of symmetrical data sets on men and women, partly due to methodological issues of access, though 
mainly due to the fact that men's and women's experiences are so different, any 'comparison' is likely to be based on secondary material. Nonetheless, highlighting the relative position of women, if only by stressing their absence in certain strata of the migratory population, plays an important role in contextualisation. It is also achieved through counter-reading silences and absences in men's testimonies. These yielded information both on the experiences of women and the nature of lived social relations between and among men and women, as will be seen below.

Before proceeding to a discussion of the findings, it is necessary to say a brief word on terminology, as this has important implications. Illegality refers to a status into and out of which individual migrants can move over time throughout the migration process (see the introduction to this volume). It can, of course, occur at the sending context if the bureaucratic procedures stipulated as necessary by the sending state in order to emigrate are not respected (Ghosh I998: I-4). It may also refer to migrants whose status is illegal from the perspective of destination countries due to the fact that they either enter without complying with the legal procedures required by the reception country, or they do not comply with the legal conditions attached to their residency or employment. Within Third World cities such as Karachi, rural-urban movements can also produce, in some contexts, a sort of illegal status derived from illegal residence in 'unauthorised' settlements (Shahnaz 2004).

As Ghosh (I998) underlines, the relations between all these different sorts of illegality are complex: they are not mutually exclusive, nor does the existence of one imply that any of the others will necessarily follow; migrants may move from legality to illegality and vice-versa over time. This chapter is about just one small constellation of illegal migrants within the Pakistani migration system, whose illegality derives from being smuggled into the West: ${ }^{2}$ for instance, from unauthorised transit through and illegal entry into European and other Western countries, where they reside and work, often illegally (though some eventually manage to legalise their status).

Just under half of the respondents had migrated illegally, though more than that had been involved in illegal (or rather informal) work. My sample also includes a number of men who migrated legally (though often using the services of agents and brokers who facilitate illegal migration) and then entered into situations of illegality by overstaying their visit visas, working without permission or travelling to subsequent destinations for which they did not have legal authorisation. It even draws upon the testimonies of some 'legal' migrants. This is because there is no absolute distinction between what motivates different categories of migrants in illegal situations, or even between 
those who are smuggled as opposed to those who migrate legally. Nonetheless, for heuristic purposes, I have sought to retain an emphasis on the intersecting dynamics of gender and smuggling from Pakistan to the West.

\subsection{Who makes the decision to migrate?}

Sociologists of migration who focus on transnationalism and global networks, then, frequently ignore the question of individual migrant motivation, treating the primacy of collective material betterment of the household as a given. If anthropological accounts cannot be charged with quite the economic bias that characterises these works and do address the issue of what drives migration, they suffer from a similar tendency to rule out the importance of individual desire in favour of calculating collective agency. Shaw, for instance, claims that migration 'never involved individuals leaving their families to seek fame and fortune' and is a 'means by which the kinship group as a whole could improve its lot'. 'The impetus for departure,' she goes on, is 'provided by the entire extended family' (Shaw I994: 36). This argument, based on the testimonies of migrants from Mirpur, sits squarely within the paradigm set by others before her, above all, Khan, who asserts:

The primary social unit is [...] the household [...] roles are precisely and clearly defined into a pattern of [...] individual subordination to the group (Khan I977: 60-6I). The decision to emigrate is made by family and kin [...] The head of the household, or of the immediate biraderi grouping selects the emigrant and makes the preparations. The joint decision reinforces the ties with kin and community, thus cementing feelings of affection and determination. The migrant knows he has support. (ibid.: 70)

The impression given in such accounts, consistent with conventional writings on the economic history of developing societies and strategies of the poor, is that 'the household is an unproblematic unit that allocates time and labour, pools income and distributes it fairly evenly among its members' (Fontaine \& Schlumbohm 2000: 3), a portrait that has been shown to be highly problematic in different times and places throughout history (ibid.: 5). The analyses quoted above make no mention of the fact that the migrants (and prospective migrants) they are discussing are men whose impulses to migrate are often generated in spheres beyond the household. My examination of the testimonies of illegal male migrants, in particular, reveals that the decision to migrate 
is, in fact, often highly contentious. This is perhaps hardly surprising, given that it involves the spending of a sum of cash that may be greater than the annual household income (Koser 2006) on a risky venture undertaken by a single member of the household. Most respondents who migrated illegally left Pakistan between the mid-I990s and 2003 . They paid over seven thousand pounds to agents in order to secure passage to the West, though the exact sums differ due to changes over time, variations in route and the highly unregulated nature of the smuggling business.

Several of the newly arrived migrants I interviewed belong to families that benefited from the vast, continuing migration to the Middle East that has sucked in and transformed the lives of millions across South Asia since the I970s when the Pakistani state began to adopt a policy of encouraging international emigration as a means of alleviating the country's intensifying economic woes (five of the six Pathans interviewed in London had fathers who had either been to or were still in the Middle East, which suggests the Gulf migration has had a particularly pronounced impact in NWFP, where the tradition of international emigration before the I970s had been relatively weaker than in other parts of Pakistan such Punjab). Throughout NWFP and Punjab, Gulf remittances have kept the economy afloat though they have had conservative effects, given the absence of structural, institutional and industrial development (Sayeed 2002: 232-236; Naseem 2002: 25I). The deteriorating socio-economic position of women, reinforced by political developments, is indicative of this. The Hudood Ordinances, a series of 'Islamic' laws introduced in the I980s under the military dictatorship of General Zia, effectively criminalised female rape victims and legitimised violence against the most vulnerable females (children, the poor) of an already patriarchal society. A survey conducted with I39 households towards the end of the Zia era reported that women express 'no identity except that of their families' (Shaheed 2002: 353). 'One of the most common complaints' they had, it went on, was that 'they had very little freedom of movement' (ibid.: 364 ). Indeed, a report published in 2004 noted that, based on the results of the 1998 population census, 84 per cent of women who migrate within Pakistan do so for marriage or move with the head of the household (Shahnaz 2004: 22). Female labour market participation rates in Pakistan are amongst the lowest in the world (ibid.: 34).

It is against this backdrop that we must view the attitudes and behaviour of illegal Pakistani male migrants in the West, a relatively privileged group within their own country. Many of the smuggled migrants I encountered had grown up with fathers leading transnational existences between home and the Gulf, and saw it as quite normal for men to live and work abroad. Twenty-four-year-old Khan Saab, from 
Kohat in the NWFP, explains the gendered, international geography by which households in his area are connected to foreign destinations through a single male migrant:

The lifestyle there is different - joint families. We live together with four of my father's brothers. One has two wives. I'm one of seven siblings. We're 40 people in one house. [...] Every family has someone outside. A guy who leaves feeds 40 people. [...] My father and three of his brothers are in Qatar. They drove trailers there. They have been there since before I was born.

Khan Saab's silence on women, who barely feature in his life story, was broken only when I asked him how the migration process affects them. Pointing to his shoe, he told me that in his village, a woman's worth is no greater than the height of a man's foot; that a brother shoots his own sister if she dares even suggest a preference for a marriage partner to her male relatives. He expressed opposition to education for women, yet sees it as entirely natural for him that men should want to improve themselves over generations: 'My dad said: "I don't want you to do that [drive tractors]". I decided I'd come here. I liked the idea of coming here rather than Qatar.'

His testimony would appear to confirm what we already know from extant literature on the impact of remittances from the Middle East (and indeed the West) upon gender relations in Pakistan, most of which demonstrates conclusively that the 'capital-rich' developmental consequences of emigration are at best ambivalent (Ballard 2003: 72). If anything, it is not uncommon for women to experience greater seclusion and confinement to their homes when their households are lifted out of material poverty by overseas male migrants, who tend to deploy their resources to impose stricter purdah and increase their own social standing within patriarchal communities, in which confining womenfolk to the home confers prestige upon the household (Gardezi I995: I00).

Perhaps this goes some way towards explaining why some Pakistani women express such ambiguous sentiments about the decisions of their male household members to migrate. Despite having little say in the matter, wives are well aware of the fact that they are directly affected by the risk entailed in the process. Often they contribute to raising the requisite capital through the sale of their jewellery, and often they express mixed feelings about the venture (Koser 2006). Their scepticism may well derive from the distinct possibility that, where benefits do accrue from migration, they are seldom distributed equally within the household. Saif, a Punjabi textile worker in Prato, admitted: 
No wife wants her husband to go away. Sensible women don't want their husbands to leave the country. If he makes money, it stays with him. As far as women are concerned, money stays within the hands of men.

Leaving aside material issues, the departure of a husband can weaken the position of wives of migrants within the extended household. When asked what his wife said about his coming to Italy illegally, Faizal told me that "wives in Pakistan say nothing. They say, "You know what's best".' When probed, however, it emerged that his wife had been against his emigrating, but that he had ignored her wishes. 'When a man leaves,' he explained, 'he goes for two years at a time,' leaving his wife living alone with her in-laws, 'not knowing when he'll be coming back'. This state of uncertainty is heightened in illegal migration, which does not afford migrants or their wives the luxury of knowing when (or if) they will return (or indeed arrive).

Attitudes within households are not simply carved up along the lines of sex, of course. Age and generation also play a role. It is not unusual for other male members of the household to be unenthusiastic about the risks that come with human smuggling. The following fairly typical accounts of parental reactions are revealing; in two cases, parents were not consulted by sons at the time they enlisted the services of an agent and were only told at the last minute, when the fee had to be paid, at which point they had to be cajoled into supporting what they regarded as an unnecessary and irrational endeavour that would jeopardise their son's physical safety:

Asad: I decided myself to leave, a long time before I did. [...] My father told me not to go. He said: 'It's very dangerous, come to Qatar and look after my business with me.' I didn't listen to him. I wanted to come here.

Chima: From the beginning Dad said, 'What's the need to go outside? What do you lack here?' I told him three days before leaving. When he found out he swore at me!

Anjum: I got the money off my parents and paid an agent. It was difficult to get them to agree. We don't have that much money. I made a fuss and they had to give in the end. Parents do their best to fulfil their children's wishes.

A number of important messages emerge in the narratives of these migrants, the first of which is that the decision to migrate illegally is, in some cases, an individual one that is sometimes made outside of, and of- 
ten against the wishes of the household. The second is that it is not necessarily a product of collectively made, economically rational calculations geared towards increasing family well-being and elevating the clan's social status. This raises the question of what it is, exactly, that drives migrants to take up the mortal risks that are involved in illegal migration.

\subsection{The romantic appeal of illegal migration}

Anthropological accounts of the migration process have long alluded to the fact that perceived inequality or 'relative deprivation' play a key role in triggering further emigration in competitive rural communities. By flaunting commodities purchased from abroad and ostentatiously conveying their newly acquired wealth, returnees and their families are thought to have given themselves and vilayat [England] a kind of mythical, elevated status. Ballard and Ballard (I977: 27), for instance, argued that 'symbols of success (e.g. clothes, watches, suitcases) and reports of the new life create a half-picture, a distorted image. The difficulties encountered in vilayat [...] are minimised to ensure the delight and pride of family and kin (ibid.: 69)'. Khan, likewise, wrote of the 'glamour' conferred upon Mirpuri returnees (ibid.: 7I).

However, such accounts treat the sending context simplistically as a site where the diffusion of a 'distorted' misconception of what migrating entails proliferates (as if there existed a single 'true' picture), and do not explore the phenomenological complexities that surround the attraction of returnees' possessions. Interviews with migrants who witnessed events in the periphery during the I960s and I970s suggest that smuggling grew organically from the initial small-scale acts of UK returnees who brought goods with them and then actively spread the word and recruited individuals and groups of men to be transported overland (illegally) to the UK for payment of a fee. The importance of this two-way exchange of commodities, people and information along overland smuggling routes in the lives of young men is clearly evident in the testimony of Nadir, whose village of origin (Dinga) lies in Gujrat district, where (together with neighbouring Mandi Bahauddin) human smuggling rates to the West are purported to be the highest in the whole of Pakistan by the Pakistani officials I interviewed:

They would come in transit vans purchased in the UK and bring consumables and gadgets, and on the way back take family members. They'd make them wait in France and Holland, make a trip to the UK and return for them - a different route. Or they would brief them on how to get through to the UK, beat immigration laws, and they'd come independently. [...] Someone cle- 
ver would take ten to twelve [men], and work out a way to get them to the UK. This was the early Sixties.

Remittances and the introduction of commodities, it seems, ushered in ever more market-based social relations, consumerist ideologies and individualistic desires, which stimulated further demand for the services of human smugglers. Indeed, as the I970s wore on, state sponsored capital-rich development in areas with high rates of emigration gave rise to patterns of conspicuous consumption which developed to the point where Pakistan, one of the poorest countries on earth, had by the I980s acquired a penchant for imported luxury goods, despite its subSaharan African levels of development and appalling social indicators. The formation of a powerful, ever more widely diffused consumerist ideology of migration took hold in rural Punjab in this period, as is clear from the recollections of Faizal, a middle-aged migrant I interviewed in Italy who also grew up in a village in Gujrat in the I970s and ig8os. His testimony sheds further light on the importance of the 'gadgets' mentioned in this last account. The appeal these held is vividly remembered decades on, in a telling account of the manner in which he and his friends would covet the material possessions of returnees. Asked why he first migrated to Kuwait at the age of seventeen in I980, he stressed that financially, 'we were comfortable'. His parents pleaded with him to stay put, but he and his friends had other ideas:

Our thinking was this: whichever guy comes from outside, you see them wearing white clothes. He's holding a good suitcase in his hand [...] he'll wear white clothes, and be wearing a gold watch.

\section{Do you remember seeing these guys?}

Absolutely. When I passed my matric I thought I should go: 'What's the point in staying here, working the land with your parents. You'll get nothing. I'll go outside and make good money. I'll come back wearing watches and stuff.' [...]

When we would see them, it felt as though we should go as well. We felt stuck there. We thought we should go, too.

Where would you see them?

We would see them when we were going around in the bazaar.

So you would know they were from outside just by looking at them? 
Everyone knows what everyone is doing there. You know so-andso is back from England; so-and-so is back from Saudi or an Arab country.

Several respondents referred to returnees' 'white' clothes. Whiteness, in their minds, appears to have denoted novelty and newness, and was associated with commodities, affluence, power and exclusivity - all signs of having left behind the unglamorous world of agriculture where people have to work for a living. Faizal explains, 'A man who works and lives in Pakistan, he'll work. Sometimes he might wear good clothes. Sometimes he won't. But if a man returns from abroad - he won't go to work.' Those who had been abroad, it seems, were associated with various kinds of elevated social distinction from the communities to which they belonged in rural Punjab. The latter came to be perceived as the domain of the socially (and spatially) immobile - those condemned to a dull and mediocre existence, bound to families and households: 'stuck', to use Faizal's words.

The insights of Cambell (I987) in his analysis of the romantic ethic and the spirit of modern consumerism in the West are worth reflecting on here, since they highlight some of the core values of modern consumerism and the way in which these can transform perceptions of what constitutes a desirable existence. Defined by him as a kind of 'illusory hedonism' that emerged after the industrial revolution with the formation of middle-class living above the subsistence level, it is distinct from 'traditional' hedonism in that 'the joys of longing rival those of actual gratification' (Cambell I987: 203). Modern consumerism is associated by Cambell with a 'dissatisfaction with real life and eagerness for new experiences' that have come to shape modern life, which is characterised by 'the ceaseless consumption of novelty' (ibid.: 205) and a tendency to 'create desire' (ibid.: 222). The attraction to migration of youth in rural Pakistan since the I960s has been characterised increasingly by this sort of modern romantic spirit: taunted with glimpses of the pleasures that consumerism has to offer, they daydream of acquiring the riches necessary to purchase and experience them through migration. Like illusory hedonists in pursuit of new experiences, they imagine the adventure and novelty migration promises to bring.

But how does all this relate to issues of illegality, given that successive and parallel waves of legal and illegal migration have been and continue to be immersed within the same romantic consumer migratory culture? Clearly it would make little sense to posit a radical distinction between processes that enmesh diverse modes of labour migration from given localities and social contexts. The consequences of illegality in migration are too bound up with those that result from legal migratory flows, to be discussed in isolation. What seems certain, however, is 
that they do accentuate and direct existing trends and processes in important ways: if international labour migration from rural contexts is (and has always often been) by its very nature the preserve of the young, the ambitious and those with a penchant for risk-taking, my data suggest that migration control intensifies the romantic appeal behind decision-making, reinforcing these tendencies and pushing them, in some cases, to extremes. It is no coincidence that, despite unprecedented levels of restrictionism, migration more than ever holds the imagined promise of material and experiential novelty to Pakistani youth, despite the fact that, in objective terms, it offers fewer obviously identifiable rewards than it did in say, the I970s. Indeed the two augmentations - in restrictionism and the desire to migrate - are arguably related. Certainly historically, the mystique surrounding migration has been greatly intensified by the increase of restrictive measures taken by the British government since the beginning of the ig6os. Only a small number of people from South Asia had taken up the opportunity to migrate following the British Nationality Act of I948, which left something of an open door for Commonwealth populations to enter the UK. The passing of the 1962 Commonwealth Immigration Act changed this instantaneously: by subjecting New Commonwealth labour migration to Britain to reduced strict quotas, the British state unwittingly stimulated the immigration to hitherto unseen numbers as thousands rushed to 'beat the ban', a number of whom may never have migrated had it not been introduced (Hiro I973: I06-I09; see also Shaw 2000: I5-20). In 1960, migration from the subcontinent was still only 7,500. In I96I, 48,000 entered Britain as rumours of impending anti-immigration legislation circulated (Hiro I973: I08). It was at that very moment, my research findings reveal, that human smuggling in its modern form from South Asia to the West began, not, as is often assumed, in the I990s, the ig8os or even the I970s.

Several migrants I interviewed, by their own admission, were lured by the forbidden nature of migration as young men and cited wanting 'to see' what lies behind the purdah [curtain] as their main purpose. Tanvir, a 38-year-old self-employed grocer from Jhelum who migrated to London in 1984 explained, 'There's a purdah. You always want to know what's behind that - to see it for yourself. Even if the next man tells you there's nothing there, you will want to see for yourself.' One of nine boys in his FA class of eleven who migrated at the same moment in the early I980s, attributed his actions to impulsive 'young blood' and lust for adventure, issues to which I turn in more detail in the next section.

Beyond the issue of creating mystique, moreover, migration control has blurred the relationship between migration and consumerism, with important consequences. Restrictionism has spawned the growth 
of a vast modern 'business' in facilitation (Salt \& Stein 1997). The business in human smuggling gives return migrants and smugglers a stake in continuing to perpetuate myths about life abroad as part of a marketing strategy. This process of commodification and marketing has effectively transformed migration itself into a commodity that can and must be purchased at any cost. If migration once facilitated consumerism, its commodification through the rise of human smuggling has ensured that the two have now become synonymous in sending contexts. Migration, that is to say, is no longer simply a means to accumulate capital and consume; it is an end in itself, the realisation of which requires considerable levels of accumulation and significant levels of material investment and risk. For certain constellations of young Pakistani men who now live above subsistence, migration is itself the ultimate product and status symbol. This development, which is arguably bringing about a fundamental reversal in the very nature of labour migration, is reflected in the rising costs of smuggling, which went up by around a thousand pounds a year during the period of my conducting this research, raising ever more serious question marks over the treatment of migration as a calculated, 'rational' economic strategy.

\subsection{Sexuality and youth cultures in communities of men}

One particularly intriguing passage of Nadir's earlier quoted testimony introduces a hitherto neglected aspect of the history of labour flows from Pakistan, legal and illegal. The transit vans that transported Punjabis from Gujrat district to the UK illegally in the I96os, he explains, were part of a broader phenomenon: the traffic in cultural ideas and experiences between the West and the global South that belongs to an unwritten history of post-war globalisation. By virtue of its proximity to the major highway connecting the East to the West within the subcontinent, his village in Gujrat district was heavily exposed to the tourist trail travelled by considerable numbers of Westerners in the Ig6os. According to Indian government estimates there were ten thousand 'youthful foreigners' in the country in 1967 . Five years after the Beatles had popularised the route, the same number crossed the Wagah border from Pakistan in a single week. In I973, there were 250,000 French nationals in India alone (MacLean 2006: 205). This period coincides with the emergence of mass migration and human smuggling from South Asia to the UK. The travellers and the way they lived their 'free style of life' as they passed through the subcontinent in their thousands at the height of the sexual revolution appear to have had quite an impact on some of the young men whose field of vision they en- 
tered along the GT ('Grand Trunk') road which, built by the Mughals, acquired legendary status under the British, who coined its modern name:

I remember European people would go by road through Iran, Afghanistan and the Khyber Pass through Pindi and Lahore, from the UK. We would see them on the GT road - the motorway starting from Peshawar, Pindi, Jhelum, Gujrat, Gujuranwala and Lahore. From there they would go to Delhi. These were small vans. We saw their free style of life, their capacity to spend money and enjoy life. They were hippies, tourists. Hundreds would pass through daily. Americans, English, French. They would stop in Karian, Jhelum and Gujrat, and stay there, wherever night fell. They would stay in hotels and use tents. We had a fascination to meet them. You would go and talk to them in bars, cafés and tea places on the GT roadside. We were fascinated [...] by the women. 'What sort of people are they?' we wondered. This was the early Sixties. They were individual tourists. Also we'd see them in the trains, up until the I970s. For youth, this inspired one to leave.

This passage suggests that the sight of youngsters fulfilling their own desires to travel and discover what they thought of as 'India', enjoying their 'spending power' as well as sexual and other forms of freedom may well have played an important, as yet unstudied, role in stimulating interest in the Occident. A recently published journalistic account of the hippy trail presents much anecdotal evidence of its impact upon locals in countries as diverse as Turkey, Iran and India (MacLean 2006). The indelible impression left by the 'intrepids' and their 'liberal values' on youngsters is apparent throughout. A man in Turkey is quoted as saying, 'Their liberal values [...] spread in a soft way throughout Turkish society. Our women began to feel they had the freedom to act as they wished' (ibid.: I3). Another recounts, 'I remember the parties most of all [...] drinking wine, playing guitars [...] our mothers told us, 'Don't go near the [...] infidels' (ibid.: 5I). A former Iranian conscript remembers spying on a young woman through binoculars as she crouched behind a small bush to relieve herself in 1967 at the Afghan border: 'That sight was like the first bite of a forbidden fruit. Next I heard about an oasis [...] where hippies stopped to sunbathe and swim'. He spied on them there, too (ibid.: Io7).

The significance of all this lies in the interconnections it underlines between early human smuggling and cultural exchange rooted in the largely forgotten journeys of unthinking Western tourists. None of this early smuggling was reliant on social networks or new technologies of 
travel. Human smuggling emerged with roots in the two-way historical process of material and cultural exchange between Europe and South Asia - low tech, overland travel in both directions. As early as the I960s and for much of the I970s, pioneering returnees from Mirpur and Punjab were making return car journeys alongside of intrepid young Westerners travelling along the hippy trail. Both sets of actors spread news of a different, appealing and seductive way of life, and thus made an important contribution to the exchanges of information we hear so much about in discussions of globalisation.

In the age of mass advertising, digital television and information (internet) technology, the diffusion of sexualised images and commodified youth cultures has unsurprisingly increased. So, too, has the seductive appeal of migration, with which these cultural trends are firmly associated. The importance of youthful adventure in his own motivations was stressed by Chima, a 3I-year-old Punjabi chef in Florence who made his decision to migrate in I996 at the age of 2I:

I had a desire to go outside from early on. I thought I, too, wanted to live in a free setting. There was a desire to come, even if it harms me. I thought, 'I'll make my own money and spend it however I want. I'll get my kicks.

\section{Can't you do that in Pakistan?}

You can, but there are some restrictions. Parents say, 'Don't go here, don't go there!' You have to do what they say.

The professed desire to experience 'freedom' here aligns migration with subversion and the assertion of one's youthful, generational identity. Making money is about autonomy rather than commercial gain. When I pressed Chima about another vague reference to 'getting one's kicks', he casually mentioned leaving Italy to travel around Europe during a period of unemployment, and responded with surprise that I would assume he and other migrant workers should be any different than any other tourist or traveller in their desire and heterogeneity of interests and wants:

Nothing much was happening on the work front anyway. I went to roam around. [...] I don't stress. I had a good roam. I stayed with Yasir in Belgium - that was good. Then a friend in Germany, and then another friend in Germany. Then I went to Austria, then to another one in Slovakia, and then I came back to Italy. 
What do you do when you travel, why do you enjoy it?

Why does anyone go to Italy from Germany and Britain?

Some people say Pakistanis only leave [migrate] to work, for money.

Some people leave just for money. Some are passionate about money. Some, like me, like to roam. Like to get their kicks. Some like to get their kicks with girls. They like to fuck round. Some like to see things, to see what things are like, to see different people and countries - they see that as getting their kicks. Some get their kicks from cooking and eating with friends. Everyone has their own way of getting their kicks.

The casual association of labour migration with travel, transgression and hedonistic exploration of various kinds (including sexual adventure) was alluded to by other migrants as well. Thirty-one year old Sarfraz, whom I interviewed in Florence, had no hesitation in confirming that aiashi [hedonism] can be factor in many young men's decisionmaking, pointing out that the oppressive regime of conservative religious, social and moral control of individual behaviour in Pakistan itself makes it impossible for young men in villages to indulge in the kinds of pleasures that are routine for teenagers in the West:

Young men absolutely have it [aiashi] in mind. In Pakistan if you want to drink, you can get alcohol but it's not allowed. If the police catch you they'll put you in jail. The consequences are serious. Living with your family too is an issue. [...] If a man likes to drink, even if he can afford to, what enjoyment will he get doing it when any moment he could get caught.

\section{And women?}

Yes. If you do anything like that over there, the chance of getting beaten up is high. The risk is such that you could get shot if you [...] someone's sister or someone's daughter. That sort of thing happens all the time - you only need to read the newspapers. And so it's not easy to enjoy it.

The notion of illegal labour migration as a form of youthful subversion is a controversial argument, but one that has a basis in previous anthropologies of Pakistani migration. Werbner (I996: 88-9I) has pointed to the fact that, despite its surface level solemnity and religious character, Pakistani culture is in fact composed of diverse strands, its 
meaning contested by genders and generations. Positing a dialectical tension between the overt piety of elders who espouse high 'Islamic' ideals and a more subversive, sensuous South Asian youth sub-culture that seeks to carve out spaces of fun, celebrating the body and various sorts of transgression, Werbner cites the cult of cricket as a prime example of 'masculine glamour' that transgresses national boundaries (ibid.: 94). Illegal migration, in sending contexts, it is argued here, can be seen as another.

Indeed evidence suggests that most returnees understand this fact and the elevated status it brings them over men who have not been abroad. They swagger around town, basking in the glory it brings them. Several migrants I met confessed to putting on their 'whitest' clothes and deriving satisfaction from splashing money around in front of the immobile, deliberately giving the impression that their disposable income is greater than it in fact is. The rumours they disseminate inspire men of all sorts of ages and social backgrounds to find a way 'to see' for themselves what all the fuss was about. This underlines the centrality of relations between and among men to the dynamics of migration, which, in the communities of men under discussion, is driven by a need to enter the ranks of those who have seen and not merely heard what it is to go abroad. It amounts to masculine rejection of dependency upon others for knowledge of the world; a rejection of relegation to the lowly status, within one's community, of one who relies upon the testimonies of others for his understanding of the Occident. To remain dependent in this way is to share the status of women, for whom travelling is out of the question: international migration is, in this sense, a typically masculine, symbolic repudiation of femininity (Ditz 2004: I8).

This is not to reduce migration to the outcome of a psychological game; these processes of establishing status are embedded in a material context and have real experiential consequences. For instance, migration impacts on inter-male competition for access to women within Pakistan itself, which is central to the gender order. Within the sectors of rural middle-class society that these men occupy, marriage possibilities (the sole means of sexual and emotional development for single men) are rigidly structured by a man's social status. To be excluded from the ranks of the returnees restricts one's choice of bride and extends the wait for a suitable match, particularly in a district such as Gujrat where rates of emigration are high. For men in their twenties, this wait can be a passage of intense sexual frustration. Whilst the pleasures of sex remain tauntingly visible in the lives of the country's elites and on television through advertising and the global media, they are firmly out of their grasp in what remains a conservative society. Nor can their frustrations be easily alleviated through marriage whilst they remain un- 
employed, unless they accept a match that brings downward social mobility. When asked what it is that motivates men to migrate illegally, Shahid, a social worker I interviewed whilst doing fieldwork in Lahore, explained that what appears to be a purely materially driven phenomenon is in fact linked in complex ways to the possibilities of sex, especially for the young men of lower middle-class backgrounds who make up the bulk of Pakistan's illegal migration to the West:

They have no access to women, to sex. No access to upper-class women. They just play cricket and video games. Marriage is the only way for them to have sex. Because upward mobility for them is blocked, they feel a terrible frustration, especially those who want to see more of the world and experience what they see plastered on TVs.

\subsection{Conclusion}

The research presented here, in line with feminist interventions (e.g. Agarwal 1997), confirms that scholars of international migration from Pakistan (and by implication elsewhere in the global South) have likely exaggerated the unity of the household and underestimated the importance of expressions of selfhood in motivating migration among the privileged circles of men whose family commitments appear to conflict with their own personal aspirations. If women in Pakistan express 'no identity except that of their families' (Shaheed 2002: 353) and have 'very little freedom of movement' (ibid.: 364), some men are clearly able to pursue their own comparatively ambitious migratory agendas, irrespective of the ambiguous sentiments expressed by other members of their households - even where scepticism comes from elderly males who end up financing the expedition.

Smuggling in its modern form emerged as a consequence of British policy, which, having induced labour flows in I948, suddenly restricted them with the act of I962. Smugglers operated overland along the Silk Route, transferring people, commodities and information about the West and how to get there, carefully cultivating demand for their services. The desire to migrate however, reached new levels as emigration fever gripped the whole country in the late I970s, a development reinforced by policies of the Pakistani state. Gulf remittances and the introduction of commodities, it seems, ushered in ever more market-based social relations, consumerist ideologies and individualistic desires which stimulated further demand for the services of smugglers as destination states began tightening up their borders. Migration itself became a commodity, promising all the pleasures of 'modern illusory he- 
donism: novel experiences that could be imagined and romanticised from afar. Its mystique has been compounded by its forbidden status in an age of growing controls and restrictions. Its association with exotic alterity and cultural difference gives it an emancipatory, subversive and youthful appeal to men of various backgrounds, in whose minds it is associated with adventure, sexual freedom, power and elevated status. More generally, it confers glamour on returnees and thus affects social relations between and among men, above all by mediating access to women in the marriage market.

What drives the will to migrate, it seems, is often the experience of deprivation and inadequacy that comes with immobility within communities of men where the cult of the 'globe-trotter' gets established as a locally entrenched hegemonic masculinity. In such instances, ironically, it is not networks themselves that drive migration. The 'information' that circulates throughout such communities is hardly 'social capital'; returnees trigger the desire to migrate beyond their own 'networks' by wilfully instilling a sense of marginalised exclusion amongst those who are external to them. Some of the sentiments which motivate them have in fact been observed in other labour migrations throughout history, including those of young women: the desire to 'see more of the world', for example, is identified by Henkes in her study of German maids migrating to the Netherlands during the interwar period (200I: 225-226). This suggests that a desire 'to see' more of the world is not exclusive to men and in fact is typical amongst young people in all sorts of contexts. On a further comparative note, when juxtaposed with Van Liempt's findings, my research underlines just how different the motivations of smuggled migrants from different places and contexts can be, despite the fact that they often use the exact same channels to reach Europe from the global South. Illegal migration for some young male labour migrants is a risk-taking activity embarked upon from a position of relative security. The reverse may well be true for many refugees and asylum seekers - especially women, for whom smuggling routes are likely to be perceived as a way of attaining greater security from positions that are anything but secure. Viewed over a long period of time, all migratory outflows from Pakistan remain enduringly gendered, and owing to illegal migration have become more male-dominated.

The role of the state in reinforcing conservative 'religious' attitudes appears to have been crucial in the gendering of migration from Pakistan, just as it was in other times and places. In Portugal (Brettell I986: I36) and Spain (Sarasúa 2001: 31-33), women were forbidden by law to migrate; the Irish 'tradition' (Delaney 200I: 220) of independent female labour migration, conversely, is arguably a reflection of the fact that the state did not outlaw female emigration, despite the efforts of 
the church. In Pakistan, no such laws explicitly prohibit women from emigrating from Pakistan, but the effect of laws such as the Hudood Ordinances on attitudes, along with the impact of growth-oriented policies that sacrifice social and human development, have contributed to reinforcing the breadwinner model and producing very little in the way of tangibly progressive social change. Indeed, even in the absence of explicit discriminatory laws, the position of Pakistani women is in some respects more subordinate than that of Portuguese women in the nineteenth century, who, despite living under a similarly patriarchal migratory regime, had always been able to preserve their status in society by virtue of their pivotal role in the agricultural economy. This was reflected in the fact that there was little stigma attached to spinsterhood (Brettell I986: 139) and in high rates of illegitimacy, which were in turn an index of interaction between the sexes ('mingling in the fields'), suggesting that women were never fully confined to the private sphere (ibid.: 2II, 249-250).

\section{Note}

I Some of the research drawn upon here was conducted at the Migration Research Unit of UCL Geography Department as part of the Leverhulme Project on Smuggling and Trafficking. Thanks to the editors of this book, Richard Staring, Pnina Werbner and Kaveri Harris for comments on an earlier draft of this chapter.

\section{References}

Agarwal, B. (I997), 'Bargaining and gender relations: within and beyond the household', Feminist Economics 3(I): I-5I.

Arango, J. (2004), 'Theories of international migration', in D. Joly (ed.), International migration in the new millennium, I5-35. Aldershot: Ashgate.

Ballard, R. (2003), 'A case of capital-rich development: The paradoxical consequences of successful transnational entrepreneurship from Mirpur', Contributions to Indian sociology, 37(I\&2): 49-8I.

Ballard, R. \& C. Ballard (I977), 'The Sikhs: The development of South Asian settlements in England', in J. Watson (ed.), Between two cultures, 2I-56. Oxford: Basil Blackwell.

Becker, G. S. (I976), The economic approach to human behaviour. Chicago: Chicago University Press.

Brettell, C. (I986), Men who migrate, women who wait. Princeton, New Jersey: Princeton University Press.

Cambell, C. (1987), The romantic ethic and the spirit of modern consumerism. Cambridge: Basil Blackwell.

Charsley, K. (2005), 'Unhappy husbands: Masculinity and migration in transnational Pakistani marriages', The Journal of the Royal Anthropological Institute II(I): 85-105.

Dahya, B. (I974), 'Pakistani ethnicity in industrial cities in Britain', in A. Cohen (ed.), Urban Ethnicity, 77-II9. London: Tavistock. 
Delaney, E. (200I), 'Gender and twentieth century Irish migration, I92I-I97I', in P. Sharpe (ed.), Women, gender and labour migration, 209-233. London: Routledge.

Ditz, T. L. (2004), 'The new men's history and the peculiar absence of gendered power: Some remedies from early American gender history', Gender \& History I6 (I): I-35.

Foner, N. (200I), New immigrants in New York. New York: Columbia University Press.

Fontaine, L.\& J. Schlumbohm (2000), 'Household strategies for survival', International review of social history 45 (Supplement 8: Household strategies for survival 1600-2000: fission, faction and cooperation): I-I9.

Gabaccia, D (200I), 'When migrants are men', in P. Sharpe (ed.), Women, gender and labour migration, I90-208. London: Routledge.

Gallo, E. (2006), 'Italy is not a good place for men: Narratives of places, marriage and masculinity among Malayali migrants', Global Networks 6(4): 33I-425.

Gardezi, H. (I995), The political economy of labour migration: A case study of Pakistani workers in Gulf states. Lahore: Gautam.

Ghosh, B. (I998), Huddled masses and uncertain shores: Insights into irregular migration. The Hague/Boston: M. Nijhoff.

Graycar, A. (I999), 'Trafficking in human beings'. Paper presented at International Conference on Migration, Culture and Crime, Israel, 7 July I999.

Hiro, D. (I973), Black British, white British. Harmondsworth, Pelican (Penguin).

Henkes, B (200I), 'Maids on the move', in P. Sharpe (ed.), Women, gender and labour migration, 224-243. London: Routledge.

Hoerder, D. (I997), 'Segmented macrosystems and networking individuals: The balancing functions of migration processes', in Jan Lucassen \& Leo Lucassen (eds.), Migration, migration history, history: Old paradigms and new perspectives, 73-84. Bern: Peter Lang.

Khan, V. (I977), 'The Pakistanis: Mirpuri villagers at home and in Bradford', in. J. Watson (ed.), Between two cultures, 57-89. Oxford: Basil Blackwell.

Koser, K. (2006), 'Human smuggling: Theoretical and empirical perspectives from Pakistan, Afghanistan and the UK'. Paper presented at the Leverhulme Conference on Mobility, Ethnicity \& Society University of Bristol, I7 March 2006.

Maclean, Rory (2006), Magic bus. On the hippie trail from Istanbul to India. New York: Viking.

Massey, Douglas S., Joaquin Arango, Graeme Hugo, Ali Kouaouci, Adela Pellegrino \& J. Edward Taylor (1998), Worlds in motion: Understanding international migration at the end of the millennium. Oxford: Clarendon Press.

Morokvasic-Müller, M., U. Erel \& K. Shinozaki (2003), 'Introduction: Bringing gender into migration', in M. Morokvasic-Müller, U. Erel \& K. Shinozaki (eds.), Crossing borders and shifting boundaries, Vol. I: Gender on the move, 9-22. Opladen: Leske + Budrich.

Naseem, S. M. (2002), 'The crisis of growth and economic management in Pakistan', in S. Naseem \& K. Nadvi (eds.), The post-colonial state and social transformation in India and Pakistan, 245-279. Karachi: Oxford University Press.

Pessar, P. \& S. Mahler (2003), 'Transnational migration: Bringing gender in', International Migration Review 37: 812-846.

Phizacklea, A. (2003), 'Transnationalism, gender and global workers', in M. MorokvasicMüller, U. Erel \& K. Shinozaki (eds.), Crossing border and shifting boundaries, 79-Ioo. Opladen: Leske + Budrich.

Salt, J. \& J. Stein (1997), Migrant trafficking and human smuggling in Europe: A review of the evidence. Vienna: International Organisation for Migration.

Sarasúa, Carmen (200I), 'Leaving Home to help the Family? Male and female temporary migrants in eighteenth- and nineteenth-century Spain', in P. Sharpe (ed.), Women, 
Gender and Labour Migration. Historical and Global Perspectives, 29-59 London: Routledge.

Sayeed, A. (2002), 'State society conjunctures and conjunctures', in S. M. Naseem \& K. Nadvi, The post-colonial state and social transformation in India and Pakistan, 203-244. Karachi: Oxford University Press.

Shaheed, F. (2002), 'Women's experiences of identity, religion and activism in Pakistan', in S. M. Naseem \& K. Nadvi (eds.), The post-colonial state and social transformation in India and Pakistan, 343-390. Karachi: Oxford University Press.

Shahnaz, L. (2004), A new perspective on poverty and migration issues in Pakistan. DFID \& RSPN: Quaidi-Azam-University.

Shaw, A. (I994), 'The Pakistani community in Oxford', in R. Ballard (ed.), Desh Pardesh: the South Asian presence in Britain, 35-57. London: C. Hurst.

Shaw, A. (2000), Kinship and continuity: Pakistani families in Britain. Amsterdam, Abingdon, Marston: Harwood Academic.

Tilly, C. (I990) 'Transplanted networks', in V. Yans-MacLoughlin (ed.), Immigration Reconsidered, 79-95. New York: Oxford University Press.

Werbner, P. (I996), “Our blood is green": cricket, identity and social empowerment among British Pakistanis', in J. MacClancey (ed.), Sport, identity and ethnicity, 87-III. London: Berg. 


\title{
7 Migrant domestic workers in the Middle East
}

\author{
Annelies Moors and Marina de Regt
}

This chapter sets out to contribute to ongoing debates on gender and illegal migration by focusing on migrant domestic labour in the Middle East. ${ }^{\mathrm{I}}$ Whereas in the course of the last decade gender has been taken up as an analytical category in migration research and the trend towards the feminisation of migration has been acknowledged (see Donato, Gabaccia, Holdaway, Manalansan \& Pessar, 2006; Mahler \& Pessar 2006), little academic research has been published on the migration of women to the Middle East, the large majority of whom are migrant domestic workers. Moreover, if attention has been paid to the migration of women this has by and large been limited to journalistic writings and reports of international and non-governmental organisations that focus on trafficking and abuse (some examples are Beasley I992 and Bou Habib I998; for a critique of the 'victim' perspective see Moors 2003). Such a one-dimensional approach runs the risk of negating the agency of female migrants and may even result in attempts at regulation that may further restrict their field of possibilities rather than strengthen their position.

In this chapter we argue not only that the boundaries between legal and illegal migration are blurred, but also that the effects of being legal or illegal need to be identified for particular categories of people. Not only are processes of migration gendered (including their legal aspects), but there are also major differences between female migrants, depending upon the nature of their employment. In this chapter we focus on how gender intersects with legal/illegal forms of migration for one particular category of female migrants: migrant domestic workers. Whereas gender is crucially important with respect both to state policies and to what the public finds acceptable, the ways in which this works can only be understood when taking into account the particularities of the female migrants' employment as domestics. Before analysing how gender is at stake at various moments in the migration process, we will start with an introductory note on the feminisation of migration in the Middle East, legal and illegal migration, and the gender of paid domestic work.

The chapter is based on research done in a number of countries in the Middle East. Annelies Moors conducted life-story research on wo- 
men domestic workers and cleaners among Palestinian women on the West Bank in the early I990s and in 2003, and took part in the SSRC programme 'Migrant Domestic Workers in the Middle East: Becoming Visible in the Public Sphere', which included research visits to Istanbul, Beirut, Dubai, Amman and Indonesia (Moors, Jureidini, Özbay \& Sabban, forthcoming). Marina de Regt did extensive anthropological fieldwork among domestic workers in two cities in Yemen and in Ethiopia in the period 2003-2006. The main research methods used were observations at work and at home, informal interviews with domestic workers and employers and topical life story interviews with domestic workers. In addition, in-depth interviews were carried out with key informants working at government institutions, embassies, nongovernmental organisations, and newspapers, in order to investigate public debates. Where no sources are mentioned we are referring to our own research.

\subsection{The feminisation of migration to the Middle East}

Although the mobility of people in the Middle East has a long history, it is especially after the sharp rise in oil prices in the early I970 and the rapid increase of wealth in the oil exporting countries that labour migration became crucially important to these countries. ${ }^{2}$ Most studies about migration to the Middle East, and particularly to the Gulf countries, argue that up until the I980s the large majority of labour migrants were male and that only in the I980s and I990s did migration trends start to become more diverse (see for example McMurray I999). Whereas it is true that female migration increased rapidly in the late I980s, it was not a completely new phenomenon. From the I950s on, women had started to migrate from the poorer Arab countries to the wealthier ones. Large numbers of Palestinian, Syrian and Egyptian teachers were hired to work on the Arabian Peninsula to set up an educational system for girls. This type of labour migration was strongly stimulated by a combination of factors: a very low female literacy rate in the Gulf countries, a strong preference for women teachers in girls' schools and the fact that Modern Standard Arabic is the written language in the entire Arab world, which created a transnational Arab labour market for teachers.

Whereas teaching is generally considered one of the most respectable types of employment for women in the Middle East, this was not so in the case of nursing, which is far more often considered a low-status profession (see El-Sanabary I993; De Regt 2007a). So nurses were mainly recruited from low-income countries outside the Arab world, such as the Philippines and India (see for example Percot 2006). More 
recently, both teaching and to a lesser extent nursing have become the targets of projects that aim at 'nationalising' the labour force. Young women from the Arabian Peninsula have replaced foreign Arab teachers, while in poorer countries local women have also replaced foreign nurses. In Lebanon and Jordan, for instance, Filipina women turned to working as domestic workers when they were no longer being hired as nurses. ${ }^{3}$ Indeed, since the I970s the employment of foreign women as domestic workers has rapidly grown, at first in the wealthier Gulf states and later also amongst the new middle classes in countries such as Lebanon, Jordan and Yemen. In other words, the partial feminisation of labour migration to the Middle East is first and foremost due to the large influx of migrant domestic workers from Asia and, to a lesser extent, Africa.

\subsection{Legal versus illegal migration?}

While terms such as 'legal' versus 'illegal' or 'regular' versus 'irregular' are easily used to categorise migrants, they are, in fact, far from selfevident. Rather than representing a dichotomy, the categories legal/illegal and regular/irregular refer to a wide variety of positions migrants take up in the course of their migratory trajectory. One issue at stake is that migrants move in and out of legality/illegality because labour migration is differently legalised in countries of origin and countries of employment. Whereas it is true that the number of international conventions that are relevant to issues of migration and migrant domestic labour is increasing, legislation is still first and foremost national legislation (for a similar situation in the Netherlands see Van Eijl's chapter in this volume).

Discussions about legal versus illegal migration would benefit from a broader scope, to go beyond legal rules and regulations and include normative notions. Abraham and Van Schendel (2005) differentiate between (il)legality and (il)licitness: that is, the differences between the formally legal and the socially acceptable. Certain illegal practices may well be considered acceptable (at least in the eyes of some), while practices that are technically legal may be deemed unacceptable. Including such normative notions would further stimulate a more developmental and process-focused approach. Legal activities that are considered unacceptable may in due time be criminalised, while activities that are technically illegal but widely considered acceptable may be legalised.

One major issue at stake is then in whose eyes certain practices are acceptable or not. While in debates about legal versus illegal migration the focus has generally been on state actors, in this chapter we intend to widen the focus not only by looking at state actors and their desire 
to control and regulate, but also by including the perspectives of migrant domestic workers. The latter are a particularly interesting category because of the specificities of their position. They are not only female migrants but are employees in what is referred to as the private sphere, which is not recognised as a site of employment. ${ }^{4}$ Because of this, migrant domestic workers face particularly strong tensions between what is legally allowed and what is deemed socially acceptable.

\subsection{The gendering of women's paid domestic work}

In focusing on gender we will not systematically compare male and female migrant domestic workers. This is not only because few men in the Middle East are engaged in this form of employment (and if they are, it is usually in specific tasks such as driving and gardening), but also because it is quite possible to analyse gender by focusing on either men or women. It has been taken for granted that paid domestic work is women's work par excellence, both because it entails house and care work and because it is conducted in the domestic sphere. Historical studies show, however, that in parts of the world where women's labour currently predominates in paid domestic work, a large number of men have previously been employed (Rollins I985; Moya 2007), while in some areas such as Zambia (Hansen I986; I99I) and India (Ray 2000; Tolen 2000) men continue to be employed.

Still, even if the large majority of present-day migrant domestic workers are indeed women (and sometimes children), women's employment in this field is far from 'natural'. As Hansen (I99I) has argued, the gendered nature of paid domestic labour has remained under-theorised. In many settings there are strong tensions between women's employment as migrant domestic workers and existing gendered divisions of labour, centring on the ideals of motherhood and notions of sexuality (see for example Constable 1997b; Lan 2006). Moreover, it is important to recognise that gender is only one aspect of a person's positionality. Gender always articulates with multiple axes of differentiation, such as class, age, religion, nationality and so; while gender does transform the meaning of class, for instance, the opposite is also true (Mahler \& Pessar 2006: $28 \mathrm{ff}$ ). When analysing the restrictions migrant domestic workers face, it is important to untangle whether and how this relates to their class position, to their gender, to their being migrants or to their field of employment.

The following section will discuss the gendering of migrant domestic labour for the five 'moments' in the migration process at which illegality may occur: leaving, travelling, residing, working and returning home. Our main argument is that whether being legal or illegal is an 
advantage or disadvantage to migrant domestic workers depends very much upon the rights and duties this entails.

\subsection{Leaving the country of origin: Intentions, debates and policies}

Most literature on migrant domestic workers assumes that they cross borders as labour migrants to improve the economic conditions of themselves or their families or to get away from situations of abuse. However, in many countries, in the Middle East and elsewhere, women who work as domestics may have crossed borders for other reasons. It is striking that it is often refugee women who work as domestics, such as Sudanese women in Egypt (Ahmed 2003), Kurdish women in Lebanon (Jureidini \& Moukarbel 2004), Palestinian refugee women in the West Bank (Moors I995) and Somali women in Yemen (De Regt $2007 \mathrm{~b})$. Whereas domestic workers who came as labour migrants to the Middle East usually see their employment as part of a life project, women refugees may well end up working as domestics as an unintended consequence of their expulsion or flight, as this is the only field of employment open to them. Since they do not leave their country of origin as labour migrants, a discussion of the particularities of their position falls outside the scope of this chapter.

The countries of origin of migrants working as domestics in the Middle East have divergent policies with respect to migration. Some, such as the Philippines, where remittances from migrants have become a major source of income, have a history of actively encouraging and controlling labour migration, including that of migrant domestic workers (Parreñas 200I). The Filipino embassies organise activities for migrant workers, provide facilities for them and more generally attempt to keep migrant workers tied to their country of origin, where they are welcomed as 'economic heroes' (Constable I997a). Filipina migrant domestic workers are required to go through private government licensed agencies and to participate in pre-departure orientation. In fact all women who migrate as domestics are supposed to do so through the Philippine Overseas Employment Administration. They are also not allowed to work below a certain wage level, which is contractually arranged before leaving (however, these contracts are not enforceable in the country of employment). ${ }^{5}$

Other states are far more hesitant about migration. Some ban all migration, such as Egypt before I97I, but more often they target particular categories of labour migrants. For instance, Pakistan does not allow women to go and work abroad on their own as domestics, while India only allows women over 30 years of age to do so. In 2004, Ethiopia no 
longer allowed the migration of domestic workers to Lebanon after a number of very serious cases of abuse. Moreover, in countries that try to follow the model of the Philippines and have become important sending countries of migrant domestic workers, such as Sri Lanka and Indonesia, there are major tensions and debates about the desirability of women migrating abroad as domestic workers (Gamburd 2000; Robinson 2000). Such debates may also be played out in the field of religious politics, such as in Indonesia, where Islamic groups have heavily criticised the government for allowing women to migrate on their own (rather than accompanied by a mahram, a closely related male or husband).

Public debate has in some cases resulted in regulating the migration of domestic workers. One striking feature is that women's work as domestics is not in itself considered problematic; all these countries have large numbers of poor women who are locally employed as domestics. It is only when women do the same work abroad that it becomes an issue of public concern. ${ }^{6}$ This relates to the notion that women embody the nation, while men are the real citizens of the state. A particular notion of femininity, which centres on morality, motherhood and sexuality, is at stake here, as is a particular construction of masculinity, with men as the protectors of women (see for example Gamburd 2000: 229). The bottom line is the power imbalance between the sending and receiving countries, with the former far more dependent on the latter than vice versa. ${ }^{7}$ The end result is that sending countries have few means to protect their nationals - male or female - in the country of employment.

There are many reasons why public debate focuses on abuse and victimhood. It is certainly the case that there are serious cases of abuse. Yet migrant domestic workers may also feel the need to emphasise the many hardships they face abroad, since otherwise they run the risk of being portrayed as having left their families to their own devices while they themselves are having an easy time (see for example Gamburd 2000). The circulation of such stories of abuse and victimhood may in turn pressure state institutions to restrict the migration of women domestic workers. States may then either prohibit women from migrating as domestic workers altogether or only allow them to do so under strict conditions (being above a certain age, going through particular channels, having the permission of their husbands and so on). Migrant domestic workers who are unable or unwilling to cope with these requirements then either have to give up on their migration project or proceed through illegal means. 


\subsection{Travelling and entering the country of destination}

There are two major means by which migrant domestics move from their country of origin to the country of employment: via recruitment agencies or via relatives and friends. Although it is difficult to draw a sharp line between the two, the ways in which women migrate may indicate the extent to which they have been actively involved in designing their migration project. Also, when labour migration is presented as voluntary or as the 'natural' outcome of market mechanisms drawing poor women to rich countries, people are, in fact, often induced into labour migration. Yet once a migration link has been established it may well take on a life of its own, with friends, acquaintances and kin inviting and urging women to come and join them abroad. Since migrant domestic labour has become an established practice, it is also transmitted over generations, with some following in the footsteps of their mothers. Migration has, in fact, become such a generalised phenomenon that women themselves actively turn to agents to join those who show the results of their work abroad by wearing gold jewellery, buying land and building houses.

\subsubsection{Agencies}

Agencies work in both sending and receiving countries. In sending countries, recruitment agencies organise women's migration and actively search for women who may be interested in migration abroad. In the Philippines, state institutions have been heavily involved in stimulating migration abroad (see Parreñas 200I). In Indonesia brokers employed by agencies visit poor rural families and convince young women to migrate abroad in order to help their families (see Surtees 2003). In Ethiopia brokers actively approach young women from poor families and persuade them to migrate to the Middle East (Kebede 200I; De Regt 2007a). In receiving countries employment agencies function as intermediaries between families looking for migrant domestic workers and women willing to migrate abroad. Agencies in sending and receiving countries often work together, with agencies in sending countries 'supplying' agencies in receiving countries with migrant domestic workers. Women who migrate via agencies are always employed as live-in domestic workers, with the length of the contracts generally varying between one and three years.

Some sending and receiving countries have policies to regulate the activities of recruitment agencies through a system of licenses. Yet the fact that many agencies use sub-contractors interested in benefiting from the migration business makes it difficult to control them, as Jaber (2005) shows for those involved in the Philippines-Jordan connection. 
Moreover, the policies of sending and receiving countries may diverge substantially. In Yemen there were until recently two agencies licensed by the Yemeni Ministry of Social Affairs and Labour that recruited Ethiopian women as domestic workers, but neither of these was recognised as a legal agent in Ethiopia. Both lost their licenses after serious human rights violations including the withholding of passports, the delay of the payment of salaries and physical abuse, but they continue their activities without a license, as do many other agents. The Yemeni Ministry of Social Affairs and Labour lacks the facilities to systematically control the activities of illegal recruitment agents, while the financial and political interests that accompany the illegal immigration and employment of young women workers also hamper attempts to regulate it (De Regt 2007a). Some migrant women themselves prefer to make use of agents who do not work according to the law because the bureaucratic procedures that are involved in legal migration take so long.

Many formally legal (that is licensed) agencies actually employ illegal recruitment practices that amount to trafficking. Whereas trafficking is generally equated with forcing women into prostitution, according to the UN definition recruiting migrant workers by means of deception is also a form of trafficking. As migrant domestic workers are commonly deceived about the conditions of employment and the wage levels, much migrant domestic work would fall in the category of trafficking (see Jureidini \& Moukarbel 2004). For instance, the contracts migrant domestic workers sign in their home country are often not valid in their country of employment, where they are then coerced into accepting another, far less favourable contract. Another problem is that many women are not aware of the fact that they will find themselves in a situation of illegality. Indonesian women migrating to Saudi Arabia, for example, may do so via agencies that arrange their visas under the pretext that they are going to perform the hajj. As soon as they arrive in Saudi Arabia, they are employed as domestic workers although they do not have a residence or a work permit. In some cases they may be able to perform hajj during their stay in Saudi Arabia, but in other cases this was only a way to obtain an entry visa.

Licensed, formally legal agencies may engage in other illegal practices such as asking high recruitment fees from employees, withholding passports and delaying the payment of salaries. Employers are supposed to pay the plane tickets and the costs of residence and work permits, and workers are supposed to be responsible only for the visa costs and health tests (see ILO 2004). Yet in many cases both the employers and the workers have to pay fees to the agencies for their assistance in arranging the migration and employment (see Jureidini \& Moukarbel 2004: 594). Some migrant workers may borrow money 
from relatives or friends, but others fall victim to some form of 'debt bondage'. Having borrowed money from their agents, they consequently are forced to work without receiving their salaries for considerable periods of time.

Women who migrate via agencies are also at a disadvantage because many agencies offer employers a domestic worker for a trial period of three months; if the employer is not satisfied, the agent is obliged to find a replacement. In practice this may well mean that the agency severely disciplines and punishes the domestic worker in order to 'convince' her to return to the family as a better, more submissive worker. Some agencies also strongly advise employers to restrict the mobility of the migrant domestic workers and tell them not to allow domestics to leave the house on their own (see Jureidini \& Moukarbel 2004; De Regt 2007a).

\subsubsection{Friends and relatives}

Women who migrate via relatives or friends arrive on tourist visas which they then overstay, or come on individual contracts that their relatives or friends have arranged. Networks of relatives and friends facilitate their arrival in the destination country and their access to housing and work (see Hondagneu-Sotelo 1994; Hagan I998; Beyene 2005). Sometimes women who intend to migrate as domestic workers take the initiative and ask relatives or friends to find work for them and help organise their migration, while in other cases employers ask their domestic workers if they have relatives or friends who would want to come and work for relatives or friends of the employers. Having a network of relatives or friends - and hence some support - is an important reason why women decide to migrate to a particular country. Ethiopian women in Yemen cited this as the reason to come to Yemen, even though they could have earned more elsewhere in the Middle East (De Regt 2007b).

Migrating via relatives or friends has important advantages. Women are better prepared for their work and life abroad, while the presence of relatives or friends facilitates their adjustment to a new living and working situation. Whereas networks of relatives and friends are very important for migrants' well-being in general (see Hagan I998), this is all the more so in the case of migrant domestic workers because they work in isolated situations (Hondagneu-Sotelo I994; Beyene 2005). Moreover, the fact that the families they are going to work for are known to their friends and relatives increases the chance that they will be treated well. Also, if they work as live-ins they are in a stronger position to negotiate with their employers and, with a network of friends to go to, they can more easily claim a day-off. 


\subsection{Employment and residency: Rights and duties}

The main countries of employment in the Middle East are located on the Arabian Peninsula and have a long history of contact with South Asia and Indonesia. Up until the I950s and I96os the mobility of people between these regions remained largely undocumented. Only after the oil boom did issues of residency and nationality become crucially important, especially in those cases where the foreign labour force was much larger than the very small yet tremendously wealthy national population, such as in the UAE or Qatar. ${ }^{8}$ The net result is that it has become progressively more difficult to gain permanent residency and nearly impossible to gain the nationality in these countries.

Rights to nationality are strongly regulated and are based on lines of descent rather than on duration of residency. Migrant women have an advantage over migrant men, since in the Gulf states, and elsewhere in the Middle East, nationality is by and large transferred through the male line. ${ }^{9}$ Whereas migrant men cannot acquire nationality through marriage with an Emirati national, migrant women can do so. Yet changes are taking place here as well. Whilst it used to be quite common for Emirati men to marry young women from Bombay and elsewhere in India, more recently the state has also tried to make it more difficult for Emirati men to marry foreign women. One argument used is that a considerable number of well-educated Emirati women have difficulty finding a suitable partner. The aim of the state is to support the marriages of Emirate men with Emirati women through such institutions as the marriage fund, which subsidises the costs of such marriages. In Saudi Arabia there has, in fact, been quite some publicity about men who prefer to marry women from South-East Asia, especially Indonesian women - who work in large numbers as domestics in Saudi Arabia - since they are considered less demanding and more submissive than Saudi wives. ${ }^{\text {IO }}$

In the Gulf states, and to some extent also in Jordan and Lebanon, migrants cannot work and reside legally without having a 'sponsor' (kafil), who is in most cases their employer. The sponsor is fully responsible for the employee during the contract period, which lasts between one and three years. If the sponsor decides to break the contract, the employee immediately loses his or her residence permit and is obliged to return home. Most migrant workers are prepared to endure considerable hardship rather than to shorten their contract period and return home empty-handed (Longva I999: 23). While employers are responsible for arranging residence and work permits, migrants are blamed (and sometimes criminalised) for not having them.

The dependency of migrant domestic workers on their sponsors is particularly strong because they are required to reside in the house of 
their sponsor/employer. Moreover, in these households they occupy an ambiguous position as non-family members working in a situation of highly personalised relationships. Because they work in what is considered as the private sphere, they are not covered by labour law and find themselves under the authority of the head of the household. Whereas their position as domestic workers is unregulated - as is also the case for local domestic workers and for migrant domestic workers in many other settings - as migrants they are subject to laws about immigration and residency that are very detailed.

In many countries of employment the presence of migrant domestic workers has been and still is a highly contested issue. Attempts to restrict the number of migrant domestic workers are not only fed by the general fear of the very small national populations of being taken over by foreigners. Migrant domestic workers are targeted in particular because they work in the privacy of the household and are engaged in raising the new generation of citizens. In the UAE, for instance, where foreigners far outnumber the national population, stories abound about young children who speak Malayalam rather than Arabic and who engage in non-Muslim religious practices. Such anxieties fuel the debate about the desirability of the presence of foreign domestics. Yet, at the same time, the policy of 'nationalising' the labour market is drawing increasing numbers of young Emirati women onto the labour market, which is further increasing the demand for domestic workers. Hence, measures to limit the number of domestics mainly target the foreign middle classes, who are only allowed to bring one domestic into the household and who have to pay far higher fees to do so, amounting to one year's salary (Sabban 2004).

In poorer countries where there is considerable unemployment, such as in Jordan, other arguments are used against employing migrant domestic workers. On the one hand, professional middle-class women are blamed for bringing in foreign domestic workers because they insist on working outside the home, while on the other hand poor local women are blamed for not being willing to do this type of work. ${ }^{\text {II }}$ Yet, as elsewhere, it is not simply that local women are not available or willing to do this work; employers also prefer foreign domestics since they are either more qualified, cheaper or more submissive. ${ }^{\text {I2 }}$

Public debates and, in some cases, international pressure and support have led to some improvements in the working and living conditions of migrant domestic workers. In the case of Jordan, a Special Working Contract for non-Jordanian Domestic Workers has been designed that must be signed by the employer, the domestic workers, the agency and an embassy representative. The employer can only obtain a visa, a residency and a work permit when such a contract has been arranged for. The advantage for domestic workers is that the wage level 
is acknowledged by all parties concerned. The contract also states a number of rights for migrant domestic workers, such as the right to hold one's own passport, to correspond freely with others and to receive their wages monthly. It forbids employers from imposing additional tasks on their domestic workers such as working outside the employer's residence, and obliges the employer to pay airline tickets and government fees and to provide life insurance. It also entitles the domestic worker to a weekly rest day. Only time will tell whether these rules will be adhered to in practice. Yet it is important to realise that, according to these contracts, the domestic worker is not allowed to leave the house without the approval of the employer (also not on her day off). Moreover, if the employer breaks the contract without legitimate reason, he or she is obliged to send the worker back to her country of origin at the employer's expense. In other words, the net result is that in such cases the domestic worker loses her job (Jureidini 2004).

\subsection{A trend towards freelancing}

One of the main distinctions amongst migrant domestic workers is between contract workers and freelancers (see Anderson 2000; Jureidini $\&$ Moukarbel 2004; ILO 2004). In contrast to contract workers, who are tied to and dependent on one employer, freelancers work without such a contract and can change employers. Local women or women who already have some sort of residency status (such as recognised refugees) usually work as freelancers or, less commonly, through housecleaning agencies.

In most Middle Eastern countries, migrants are officially not allowed to work as freelancers. As mentioned before, foreign workers need a sponsor, who arranges for work and residency permits. In countries where the kafala system is strictly implemented, such as the Gulf states, Saudi Arabia and Lebanon (in the case of domestic workers), freelancers sometimes pay someone to be their sponsor even though they are not working for him, which is technically illegal (see ILO 2004: 66). Jureidini (2004: 66) describes how some Lebanese have seen this as a lucrative business opportunity and charge up to I200 US dollars to act as a sponsor for individual migrant workers. Where the kafala system is not implemented, such as in Yemen, the majority of freelancers work without a sponsor. They also often work without work permits, for although control of residence status is becoming stricter, there is only limited control of work status.

Some freelancers enter the country of employment on a tourist visa, which they then overstay. Others, after having worked as contract workers, either go home at the end of their contract to return on a tourist 
visa or leave their employers and move directly into freelancing. Many share apartments with other freelancing domestics (see Beyene 2005; De Regt 2007b) and work on an hourly basis for various employers. They spend their leisure time at home, visiting friends, going shopping or going to church. ${ }^{13}$ There are also freelancers who work as live-in domestics for one family (see Ahmed 2003; De Regt 2007b). Still, the latter are also less dependent on their employers than contract workers and, as a result, usually receive a higher salary and have more freedom of movement. On the downside, they have to pay rent for their rooms, buy their own clothing and, if at all possible, pay for their residence and work permits.

An important advantage of freelancing is that these domestic workers can improve their living and working conditions by resigning and accepting new employers who offer better salaries or better working conditions. In Yemen there is a clear career pattern visible among freelancers, who move from working as live-in domestics with mainly cleaning tasks for local families to working as live-out domestics for foreigners, particularly West Europeans. The latter not only pay better, but may also provide work connections in Europe.

Freelancing is increasing in popularity, in spite of the fact that it is technically illegal. This can be better understood by taking into account the way in which migrant domestic labour is regulated. When women follow the rules and regulations for employment as migrant domestic workers, their workload is heavy yet their rights remain very limited. Hence, working as illegal freelancers may well be a move for the better. This is evident in the number of women who leave their employer and start working as freelancers with or without the approval of their sponsor. Despite immigration policies that strongly discourage any form of settlement, migrant workers have gradually gained a clear presence in certain neighbourhoods in Beirut, Dubai and other cities in the Middle East. Some have succeeded in remaining in the country for long periods of time, either by accumulating a number of consecutive contracts (engaging in circular migration with in-between trips back home) or by overstaying their visa. Still, for some sort of community to develop it is not necessary to have the same persons present for long periods of time; it is sufficient to have a regular influx of migrants (for instance, through chain migration). Such neighbourhoods are attractive as sites of residence for these freelancers, who often share a house there which may in turn also function as a refuge for live-ins who have a day off (Moors et al. forthcoming). 


\subsection{Leaving and going 'back home'}

The last phase in the trajectory of migrants is leaving and returning home. Many illegal workers face difficulties leaving the country of migration due to strict exit policies. These exit policies are meant as a way of controlling illegal immigration, though can also be seen as a means of benefiting financially from the presence of illegal migrants. Migrants have to pay high fines for each day that they have been in the country illegally. The amount of money can be so substantial that illegal migrants may get stuck in the country of migration and end up in detention centres. If an amnesty is declared - as happened in Lebanon after the tsunami - it usually refers to migrants being allowed to leave without having to pay this fine. It does not necessarily mean that they can become legal and will be allowed to stay in the country.

There are considerable differences in the regulation and implementation of exit policies. ${ }^{\text {I4 }}$ In Lebanon illegal migrants are held in detention centres and have to wait until their employers have been located (or their embassies or others are willing to pay their fines and tickets home), while in Saudi Arabia illegal migrants are immediately deported after they have been caught. Yemen used to have quite a lenient system in which illegal migrants to a large extent were tolerated. At the present time, especially as a result of anti-terror measures, the Yemeni government has started to police its borders and airports much more strictly and is implementing stricter measures, such as the introduction of exit visas and the imposition of fines for staying in the country illegally. This has caused major problems for migrant women who have been living and working in Yemen illegally for considerable periods of time. They are unable to return home since they have to pay large fines when applying for an exit visa (see De Regt 2007b). Freelancers are a particularly vulnerable group of domestics when states implement strict exit policies. Whereas they have better living and working conditions than contract workers, they work in most cases without residence and work permits and are unable to leave the country of migration because of the large fines they have to pay upon leaving.

It is not only freelancing domestic workers who have difficulties leaving. Contract workers may also face difficulties, as in cases of those whose employers did not arrange for their permits, tickets home or exit visas in order to prevent them from leaving. Filipinas in Yemen, for example, complained that some employers were so dependent on their work, particularly when their children had got used to them, that they attempted to delay their trip home by such means. In a similar vein, agencies that do not work according to the rules may also create problems for workers who want to leave. 


\subsection{Conclusion}

In this chapter we have analysed the gendered nature of illegal migration in the case of migrant domestic workers in the Middle East. It is important to mention once more that illegal migration is intimately connected with processes of state formation. Rights to residency and nationality became a highly sensitive issue in the Middle East, especially after the oil boom, because of the very small size of the national populations and the great differences in the benefits to which national citizens and foreign labourers are entitled.

Whereas the illegal migration of women is often equated with trafficking and prostitution, paid domestic labour is another very important employment sector where gender and illegality come together. Because domestic labour takes place in the private sphere, it is relatively invisible to outsiders. Domestic labour is therefore one of the few employment sectors open to illegal migrants (Schrover, Van der Leun \& Quispel 2007). In most countries, and especially in the Middle East, mainly migrant women are employed as domestics. We have argued that it is important to study not only the differences between men and women, but also the differences between female migrants, depending on the nature of their employment. One main conclusion is that it is not so much gender that is the critical issue but women's employment as migrant domestic workers. Reflecting on the question of how gender and illegal migration intersect in the case of migrant domestic workers in the Middle East, it has become clear that gender is far more important at some moments in the migration process than at other moments.

With respect to leaving one's home country, gendered notions clearly play a role, both in public debates and state policies. However, women who migrate not only face more restrictions than men, but female domestic workers are also confronted with far more obstacles than women who go into professional employment. Beginning at the moment they enter the country of employment, it is again their work as domestics that places women in a particularly dependent position, since labour laws do not apply to them and regulations about residency are particularly strict. Moreover, especially where migrants outnumber small national populations, there are strong fears about the negative effects of migrant domestic workers on cultural reproduction. Neither male migrants nor female migrants working outside households find themselves so involved in such debates.

As has been widely recognised, there is a strong tension inherent in paid domestic labour relations. While it is indeed a labour relation, it is at the same time a highly personalised relation which, moreover, is located within what is considered the employer's private sphere. 
Although the notion that a live-in domestic worker being 'like a family member' has been convincingly criticised, there are some structural similarities between live-in domestics and subordinate or dependent family members.

These inherent tensions in paid domestic labour are exacerbated in the Middle East, where there is no tradition of employing paid domestic workers. Earlier patterns of non-kin household labour included forms of domestic slavery, semi-bonded child labour and work done by client families. Although such relations were grounded in relations of inequality, they also entailed some level of protection. Currently women from marginalised groups or refugee women sometimes work as domestic workers, but they do so with great reluctance and usually work as live-out. One reason why migrant domestic workers are attractive to employers is because they agree to work as live-ins. Because they are employed in private households, they are not considered employees but rather non-kin members of household, where relations of authority are structured by gender and generation.

Hence employers, especially those in the Gulf countries, feel that they are entitled to restrict the freedom of movement of female domestic workers; after all, they would apply similar rules to the daughters of the household, and, moreover, the state holds them accountable. Yet whereas this may seem to build on earlier systems of dependent household labour, the legal regimes in which these contemporary households function are very different. The strict rules and regulations about crossing borders, residency and nationality place migrant domestic workers outside the moral community and society as a whole, which further contributes to the lack of protection many migrant domestic workers experience.

From the point of view of migrant domestic workers, being legal or illegal in itself does not mean much. The move some make towards freelancing needs to be seen in a context in which being legal entails few rights and many obligations. While freelancers are often illegal, they benefit materially and in terms of freedom of movement. The practical meaning of being illegal depends on what other resources migrant domestic workers have access to, varying from a strong network of friends, educational level (including knowledge of languages), access to means of communication, material resources, support of NGOs and so on. It may well be the case that the move to become 'illegal' is premised upon their access to such resources and hence is an indication of a relatively strong rather than a relatively weak position. Moreover, migrant domestic workers are not necessarily in favour of turning paid domestic labour into a 'purely contractual labour relation'. While some employers would actually prefer a professional over a personalised rela- 
tion, for some domestic workers it is the personalised nature of this relation that gives them extra benefits, both material and non-material.

\section{Notes}

I This chapter is based on research done as part of the research programme Migrant Domestic Workers: Transnational Relations, Families and Identities at the International Institute for the Study of Islam in the Modern World (ISIM) and the Amsterdam School for Social science Research (ASSR).

2 The highest share of migrant population is to be found in the Middle East (BaldwinEdwards 2005: 2).

3 Still, in countries such as the United Arab Emirates, with a very small national population, even a strict implementation of 'Emiratisation' will not provide enough nurses.

4 This is a widely recognised specificity of paid domestic labour, also in other parts of the world. See Hansen (I99I), Anderson (2000) and Lan (2006).

5 Although these contracts are generally unenforceable in the country of employment, such regulations are currently much debated in the Gulf countries.

6 This is in contrast with the view of migrant domestic workers themselves, who in most cases do not want to do paid domestic work in their countries of origin.

7 Labour officers employed at embassies in the countries of employment often argue that they are afraid to complain too much about the treatment of domestic workers because they would then run the risk of having their nationals replaced by domestics from less demanding countries..

8 By the mid-I990s in the UAE, 75 per cent of the population and 90 per cent of the labour force was expatriate; estimates for Dubai are even higher (Sabban 2002: 7).

9 For a similar situation in Europe see Reinecke's chapter in this volume.

Io This is similar to developments in Europe, where men sometimes marry women from outside the European Union because they are seen as more obedient and less demanding.

II This is similar to the situation in the Netherlands in the first half of the twentieth century, when German domestics were in demand (see Henkes I995).

I2 For similar cases in other parts of the world see Bakan and Stasiulis (I995), Henkes (I995) and Anderson (2000).

I3 For similar arrangements in countries outside the Middle East see Constable (I997a: I9I-I93) and Parreñas (200I: 204).

I4 For an example of expulsion policies in Germany and the different effects for men and women at the end of the nineteenth century see Reinecke's chapter in this volume.

\section{References}

Abraham, Itty \& Willem van Schendel (2005), 'Introduction: The making of illicitness', in Willem van Schendel \& Itty Abraham (eds.), Illicit flows and criminal things: States, borders and the other side of globalization, I-37. Bloomington: Indiana University Press.

Ahmed, Amira (2003), Gender, forced migration and paid domestic work: Case studies on refugee women domestic workers in Cairo. Master's thesis. School of Humanities and Social Sciences. Cairo: The American University of Cairo. 
Anderson, Bridget (2000), Doing the dirty work? The global politics of domestic labour. London: Zed Books.

Bakan, Abigail \& Daiva Stasiulis (1995), 'Making the Match: Domestic Placement Agencies and the Racialization of Women's Household Work', Signs 20: 303-335.

Baldwin-Edwards, Martin (2005), Migration in the Middle East and Mediterranean: A regional study prepared for the Global Commission on International Migration. Athens: Mediterranean Migration Observatory.

Beasley, Michel (1992), 'Punishing the victim: Rape and mistreatment of Asian maids in Kuwait', New York: Middle East Watch/Women's Rights Project 4.

Beyene, Joyet (2005), Women, migration and housing: A case study of three households of Ethiopian and Eritrean female migrant workers in Beirut and Naba'a. Master's thesis. Beirut: American University of Beirut.

Bou Habib, Lina (1998), 'The use and abuse of female domestic workers from Sri Lanka in Lebanon', Gender and Development 6 (I): 52-56.

Constable, Nicole (I997a), Maid to order in Hong Kong: Stories of Filipina workers. Ithaca/ London: Cornell University Press.

Constable, Nicole (1997b), 'Sexuality and discipline among Filipina domestic workers in Hong Kong', American Ethnologist 24 (3): 539-558.

De Regt, Marina (2006), 'Ethiopian women increasingly trafficked to Yemen', Forced Migration Review 25: 37-38.

De Regt, Marina (2007a), Pioneers or pawns? Women health workers and the politics of development in Yemen. Syracuse: Syracuse University Press.

De Regt, Marina (2007b), 'Ethiopian women in the Middle East: The case of migrant domestic workers in Yemen'. Paper presented at the Africa Studies Centre, Leiden, I5 February 2007.

De Regt, Marina $(2007 \mathrm{c})$, 'Refugee, woman, and domestic worker: The multiple tensions faced by Somali women in Yemen'. Paper for the Second European Conference on African Studies, II-I4 July 2007, Leiden, the Netherlands.

De Regt, Marina (forthcoming), 'Preferences and prejudices: Employers' views on domestic workers in the Republic of Yemen', Signs: Journal for Women in Culture and Society.

Donato, Katharine M., Donna Gabaccia, Jennifer Holdaway, Martin Manalansan \& Patricia R. Pessar (2006), 'A glass half full? Gender in migration studies', International Migration Review 40 (I): 3-26.

El-Sanabary, Nagat (I993), 'The education and contribution of women health care professionals in Saudi Arabia: The case of nursing', Social Science and Medicine 37 (II): I33II343.

Gamburd, Michele Ruth (2000), The kitchen spoon's handle: Transnationalism and Sri Lan$k a$ 's migrant housemaids. New York: Cornell University Press.

Haddad, Reem (I999), 'A modern-day "slave trade": Sri Lankan workers in Lebanon', Middle East Report: 39-4I.

Hagan, Jacqueline Maria (1998), 'Social networks, gender, and immigrant incorporation: Resources and constraints', American Sociological Review 63: 55-67.

Hansen, Karen (I986), 'Household work as a man's job: Sex and gender in domestic service in Zambia', Anthropology Today 2 (3): I8-23.

Hansen, Karen (1991), 'Domestic service: What's in it for anthropology?', Reviews in Anthropology I6 (I): 47-62.

Henkes, Barbara (1995), Heimat in Holland: Duitse dienstmeisjes 1920-1950. Amsterdam: Babylon-De Geus.

Hondagneu-Sotelo, Pierrette (I994), 'Regulating the unregulated? Domestic workers' social networks', Social Problems 4I (I): 50-64.

International Labour Organization (2004), Gender and migration in Arab States: The case of domestic workers. Beirut: ILO. 
Jaber, Hana (2005), 'Manille-Amman, une filiere de l'emploi domestique: Parcours, dispositifs et relai de recrutement', in Hana Jaber \& Francoise Métral (eds.), Mondes de mouvements, migrants et migrations au Moyen-Orient au tournant du XXIème siècle. Amman/Beirut: IFPO editions.

Jureidini, Ray (2004), 'Human rights and foreign contract labour: Some implications for management and regulation in Arab Countries', in Arab Migration in a Globalized World. Geneva: International Organization for Migration: 20I-2I6.

Jureidini, Ray \& Nayla Moukarbel (2004), 'Female Sri Lankan domestic workers in Lebanon: A case of "contract slavery"?', Journal of Ethnic and Migration Studies 30 (4): 58I607.

Kebede, Emebet (200I), Ethiopia: An assessment of the international labour migration situation: The case of female migrants. GENPROM Working Paper 3, Series on Women and Migration. Geneva: ILO.

Lan, Pei-Chia (2003), 'Negotiating social boundaries and private zones: The micropolitics of employing migrant domestic workers', Social Problems 50 (4): 525-549.

Lan, Pei-Chia (2006), Global Cinderellas: Migrant domestics and newly rich employers in Taiwan. Durham/London: Duke University Press.

Longva, Anh Nga (I999), 'Keeping migrant workers in check: The Kafala system in the Gulf', Middle East Report, Summer issue: 20-22.

Mahler, Sarah J. \& Patricia R. Pessar (2006), 'Gender matters: Ethnographers bring gender from the periphery toward the core of migration studies', International Migration Review 40 (I): 27-63.

McMurray, David (I999), 'Recent trends in Middle Eastern migration', Middle East Report, Summer issue: I6-I9.

Moors, Annelies (1995), Women, property and Islam: Palestinian experiences, 1920-1990. Cambridge: Cambridge University Press.

Moors, Annelies (2003), 'Migrant domestic labour: Transnationalism, identity politics and family relations. A review essay', Comparative Studies in Society and History 45 (2): 386-395.

Moors, Annelies, Ray Jureidini, Ferhunde Özbay \& Rima Sabban (forthcoming), 'Migrant domestic workers: A new public presence in the Middle East?', in Seteney Shami (ed.), Exploring public spheres in the Middle East and North Africa: Theory, history, gender and conflict. New York: Social Science Research Council.

Moya, Jose M. (2007), 'Domestic service in a global perspective: Gender, migration and ethnic niches', Journal of Ethnic and Migration Studies 33 (4): 559-579.

Parreñas, Rhacel Salazar (2001), Servants of globalization: Women, migration and domestic work. Stanford: Stanford University Press.

Percot, Marie (2006), 'Indian nurses in the Gulf: Two generations of female migration', South Asia Research 26 (I): 4I-62.

Ray, Raka (2000), 'Masculinity, femininity, and servitude: Domestic workers in Calcutta in the late twentieth century', Feminist Studies 26 (3): 69I-7I8.

Robinson, Kathryn (2000), 'Gender, Islam, and nationality: Indonesian domestic workers in the Middle East', in Kathleen Adams \& Sara Dickey (eds.), Home and hegemony: Domestic service and identity politics in South and Southeast Asia, 249-282. Ann Arbor: University of Michigan Press.

Rollins, Judith (1985), Between women: Domestics and their employers. Philadelphia: Temple University Press.

Sabban, Rima (2002), Migrant women in the United Arab Emirates: The case of female domestic workers. GENPROM Working Paper no. Io. Geneva: ILO.

Sabban, Rima (2004), 'Women migrant domestic workers in the United Arab Emirates', in Simel Esim \& Monica Smith (eds.), Gender and migration in Arab States: The case of domestic workers, 85-IO4. Beirut: ILO. 
Schrover, Marlou, Joanne van der Leun \& Chris Quispel (2007), 'Niches, labour market segregation, ethnicity and gender', Journal of Ethnic and Migration Studies 33 (4): 529540 .

Sinke, Suzanne M. (2006), 'Gender and migration: Historical perspectives', International Migration Review 40 (I): 82-103.

Surtees, Rebecca (2003), 'Female migration and trafficking in women: The Indonesian context', Society for International Development 46 (3): 99-Io6.

Tolen, Rachel (2000), 'Transfers of knowledge and privileged spheres of practice', in Kathleen Adams \& Sara Dickey (eds.), Home and hegemony: Domestic service and identity politics in South and Southeast Asia, 249-292. Ann Arbor: University of Michigan Press. 


\title{
8 Illegal migration, gender and health care: Perspectives from Germany and the United States
}

\author{
Heide Castañeda
}

Illegal migrants are generally excluded from social and political rights in their host countries. The study of these exclusions - and occasional inclusions - can contribute to debates on the role of the nation-state and shifting forms of citizenship. Indeed, the economic need for migrant labour often coexists with a political desire to create boundaries between foreigners and full citizens, especially in relation to resources such as health care services. The advent of illness provokes a quintessential dilemma of social responsibility for states that simultaneously condemn yet rely upon illegal immigration. In these cases, receiving states find themselves oscillating 'between sentiments of sympathy on the one hand and concern for order on the other hand, between a politics of pity and policies of control' (Fassin 2005: 366). Governments are charged with ensuring human rights to those populations within their borders, yet they are also obliged to protect scarce resources. While illegal migrants do not fall under the usual social contract between the state and its citizens, most governments concede that they should be allotted some access to basic services, especially in the form of emergency medical care. Resulting state practices often produce paradoxes that are especially fertile places for inquiry. These paradoxes open up spaces in which the state can manoeuvre, while at the same time creating the illusion that steps have been taken to discourage further undocumented migration. Fear of the 'pull factor' - that is, the fear that providing any form of benefits will encourage additional migration - means that many nations are unwilling to extend full health care rights. However, that assumption disregards 'empirical evidence showing that illegal migrants do not make a rational choice of their destination country after comparing the benefits of different welfare systems' (Romero-Otuño 2004: 250).

Nonetheless, it is analytically useful to examine how states with different welfare systems address the health needs of illegal migrants. To this end, I use a comparative approach to contrast the situation in two countries - Germany and the United States - with very different levels of commitment to their social welfare systems. This ultimately affects each state's interest in controlling migration, access to resources and policy implementation at the local level. In the following pages, I am 
going to discuss the rationale for comparing migration to these countries and examine the legal and financial situation surrounding medical care for illegal migrants in each setting. I note that despite its strong welfare state and commitment to universal health care, Germany is an extreme case of exclusion compared with many of its European neighbours. By contrast, the US health care system is predicated on notions of exclusion and categorisation, so that illegal migrants access health care in much the same way as the remaining uninsured (legal foreigner and citizen) population. Scholars have observed distinct gaps between immigration policies and their implementation in many migrant-receiving nations. As a result, seemingly restrictive yet often ambiguous policy measures contain various loopholes that provide opportunities for illegal immigrants. In particular, I point to the work of civil society organisations - such as non-governmental organisations (NGOs) and church-based charity services - that provide them with medical aid. In both the US and Germany, these organisations play a particularly prominent role in prenatal care and delivery. Van der Leun (2003) refers to these types of local informal arrangements as 'bypasses', which allow the law to be followed while simultaneously preventing the occurrence of ethically unacceptable and inhumane situations. The existence of such 'bypasses' is a prime example of how state practices adapt over time to the otherwise paradoxical circumstances surrounding illegal migration.

The situation becomes even more complex, but also more explicable, when gender and reproduction are added to the equation. Migrant illegality is constructed differentially for men and women, and the very fact that women can become pregnant while men cannot shifts the discourse. It is here that moral obligations clash most significantly with the imperatives to restrict access to the social welfare system. During pregnancy, women must locate health care resources, which can ultimately increase their visibility and deportability. Their risk is higher in welfare states like Germany where health care is costly and more vigorously protected by the state. I argue that the main concern for women in this setting is locating medical care in a highly restrictive climate, where internal control policies play an important role. By contrast, in the US illegal women may be considered less vulnerable because there are fewer instances of state aid upon which to place demands. I draw upon examples from my research to provide a portrait of pregnant illegal women's experiences in both settings. I emphasise their vulnerability and lack of rights, but also their agency in seeking out resources and making decisions.

Finally, different national models of citizenship influence discussions on migrant reproduction, even though these models are not directly related to health care access. Germany has retained a primarily 
descent-based system called the jus sanguinis or 'right of blood' model, in which children's citizenship is determined by their parents'. By contrast, the US practices a territorial jus solis, or 'right of soil' model, meaning that the children's nationality is determined by their place of birth. As a result, debates on migrant reproduction are intimately entwined with efforts to restrict the outer border of the nation. This is evidenced by the concept of citizen so-called anchor babies as migrant women's desperate and dangerous means of entering the US. Perhaps more than any other scenario, pregnancy can highlight the interplay between resources, citizenship and illegality. It offers unique insight into migrant illegality as a nuanced and often transitory category, subject to shifting policies of exclusion and social relationship to the state.

\subsection{Comparing illegal migration in Germany and the US}

I collected ethnographic data in Berlin, Germany, from 2004 to 2006 as part of a dissertation study on medical care for illegal migrants. This included six months of participant observation in an outpatient charity clinic where prenatal care represented the primary reason for visits. This fieldwork yielded in-depth observations of interaction between 204 patients and clinic staff. In addition, I conducted 6I interviews with various persons, including illegal migrants, volunteer staff from NGOs, physicians and local experts on illegal migration. Data on the situation for illegal women in the US is based on over eight years of experience working with this population as a health policy researcher in the border states of the US South-West. The cases presented here are derived from my experiences at university research hospitals along with fieldwork conducted in humanitarian organisations that provide medical assistance to migrants. Archival research and media reports added to the understanding of both settings.

While the choice of these two nations reflects my own research experiences, there are also pertinent analytical reasons for such a comparative study. Both Germany and the US are Western liberal democracies keenly interested in regulating migration through both internal policy efforts and external border controls. Increasingly, migration to both countries has been characterised by restrictive measures and selection bias against particular populations based on the specifics of their social welfare systems and labour markets (Stobbe 2004). Because laws and policy measures have taken a similar restrictive trajectory in both nations, it is important to direct the analytical focus on their local implementation. As both the US and Germany are federal systems, national-level policy must be implemented at state and local levels (see Van der Leun 2003 for a discussion of local bureaucrats as 
'gatekeepers' of the welfare state). This has particular consequences for the rights and resources available to migrants.

Despite these similarities, Germany and the US are valuable examples in their own right with at least five relevant key differences. Firstly, as noted earlier, they have strikingly different social welfare systems. To be sure, the emergence of the welfare state in Western Europe following the Second World War introduced a new concern about immigration control and migrant integration (Lucassen, Feldman \& Olmer 2006). One of the unforeseen effects of the guest worker migration to Germany throughout the I96os and early I970s was the permanent settlement of large numbers of migrants and their families. Coupled with a decrease in low-skilled jobs, many legal migrants became permanently unemployed and dependant on state benefits, resulting in strain of the welfare state by the mid-I97os. This is quite unlike the situation in the US, where migration has been and remains largely determined by labour market needs rather than the attraction of welfare benefits. As a result, Germany, like many of its neighbouring states, remains much more interventionist regarding immigrant incorporation than the US.

Secondly, the US is a classic nation of immigrants, and thus much of the current literature on illegal migration is heavily geared towards an analysis of the US situation (De Genova 2002). Meanwhile, Germany has only recently (in 2000) - and quite reluctantly - officially acknowledged that it is no longer a nation of 'zero migration'. This is despite the fact that it currently ranks as the third most popular migrant destination in the world (United Nations Population Fund 2006) and has experienced migratory movement of peoples for centuries. Importantly, even with this acknowledgement, Germany still lags behind its European neighbours in recognising the presence of illegal migrants within its borders.

Third, and related to this, the scale of illegal migration is vastly dissimilar, with Germany - admittedly a much smaller country - receiving only a fraction of the number received by the US. There are currently some I0.3 million illegal migrants in the US (Pew Hispanic Center 2006). Meanwhile, estimates suggest up to one and a half million in Germany, although this depends heavily on who is counted as an illegal. As noted in the introduction to this volume, there are multiple categories of 'illegality' - illegal exit, entry, residency and employment and each manifests itself differently depending on the nation in question. Most people enter Germany legally, either because they are citizens of states that do not require visas or by using a tourist or student visa. The visa-free entrance is intended only for short-term visits, allowing the passport holder to stay for up to three months. The vast majority of individuals who become illegal have done so as a result of this 
so-called 'tourist loophole'. In addition, because the Schengen agreement allows free movement between EU nations, there are no checks at the borders of neighbouring countries. This is quite different from the situation in the US, where only 40-45 per cent of illegal migrants, numbering at 3.2 million, enter through legal channels and then become visa-overstayers (Stobbe 2004; Cyrus 2004). Most migrants enter the US by crossing the border illegally, often under harsh environmental conditions and facing exploitation by coyote smugglers.

Fourth, despite disparities in size of the population, the presence of illegal migrants is often more visible in Germany than in the US. Once migrants reach the interior of the US, it is far easier for them to 'blend in', in part due to the large Latino population in the country. Fifty-seven per cent of all US migrants come from Mexico, with much of the remainder arriving from countries of Latin America (Pew Hispanic Center 2006). In fact, the boundary between legal and illegal immigrants is often quite blurred in the US, since amnesties and other forms of legalisation can improve the status of individuals more readily than in nations such as Germany. Furthermore, it should be noted that there are also far fewer types of population registration requirements and other forms of bureaucratic control in the US than in Germany. Thus, the need to stay hidden takes on a very different dimension. In Germany, asking for identification documents is a typical part of any interaction with official agencies, and police have the authority to randomly stop people and verify their documents. Therefore, it is important to stay as inconspicuous as possible, especially for non-European migrants. The lives of illegal migrants are characterised by the need to blend in and avoid drawing the attention of authorities. For example, many shy away from large gatherings, rarely invite friends over and may be socially isolated. Strategies to reduce visibility are important, such as making up stories of why they are in Germany and how they got there, and avoiding places frequented by the police (such as main train stations and certain parks).

Finally, as noted earlier, the foundation for citizenship is different in both nations, which shapes discussions on rights for non-citizens in particular ways. Anyone born within the borders of the US is eligible for citizenship, based on the jus soli model. Conversely, citizenship is not available to children of migrants born in Germany, which follows a descent-based system, the jus sanguinis model. In January 2000, a new German citizenship law was enacted to include some elements of the territorial model. This shift in state practice was necessitated by years of pressure from migrant communities (Turkish ones especially). For decades, second- and third-generation children of former guest workers had remained non-citizens without the right to vote, an especially frustrating situation since most had no ties to their parents' homelands. 
The most important provision of the new law allows foreigners who have lived in Germany at least eight years with legal residency status to choose dual citizenship for their children. Thus, the law rarely affects the situation for illegal migrants. Nonetheless, these shifting criteria for citizenship - along with the shifting categories of illegality - are important for understanding notions of state obligation and migrant deservingness.

\subsection{Gender, reproduction and the nation}

Because of their role in biological and social reproduction, women are pivotal members of society. Surveillance and control over women's sexual and marital behaviour has a longstanding tradition in the history of the modern state (see also Reinecke's chapter in this volume). In migration studies, analyses are increasingly attentive to gendered as well as racial constructs of citizenship. Chavez (200I, 2004) examines constructions of Latina reproduction in the US, showing how media representations are able to "produce fears about the population growth of Latinos in American society, which in turn positions them as a possible threat to the "nation", that is, the "people" as conceived in demographic and racial terms' (2004:I73). Similarly, Sargent (2006) and Tormey (2007) provide case studies from Western Europe to demonstrate how immigration regulations and population policies are inscribed on the bodies of migrant women. In her study of Malian migrants in Paris, Sargent (2006) illustrates how anti-natalist discourse coexists with otherwise pro-natalist French policies regarding family size. Women considered to be authentically 'French' are encouraged to expand their families, while fertility among African women is implicitly and explicitly discouraged by the medical practitioners. Migrant fertility is viewed with particular suspicion because of the family allocation stipend provided for each additional child under French law. Willen (2005) also explores particular notions of national belonging in her study on pregnant illegal women in Tel Aviv. She describes the patchwork of reproductive and infant health services available to them, noting that their availability is a surprising exception to the overall hostile environment for migrants in otherwise pro-natalist Israel. Finally, Tormey's study of pregnant black women in Ireland (2007) is insightful for this study because it traces the transition from a jus solis to a jus sanguinis model of citizenship brought about by the 2004 Constitutional Amendment. The Amendment was proposed amid anxieties over women who arrived in Ireland on 'maternity holiday', that is, to give birth and acquire Irish citizenship for their child. Foreign-born mothers were considered to have 'no real connection' to Ireland, and 
thus to be lacking loyalty towards the nation. This 'connection' is ultimately one of bloodline; the meaning of being 'Irish' implicitly draws upon ideas of race.

The distinct jus solis and jus sanguinis citizenship models have an impact on the debates on the reproduction of illegal migrant women. This can be elucidated using a comparative approach between particular historical settings. As noted earlier, in the US the fear of a pull factor and the resulting anchor babies has led to an increasingly restrictive policy and tougher border control. In jus soli nations, the fact that migrants without any previous ties can arrive and claim membership to the national body may be viewed as unjust. In the US, migrant women are often portrayed by the media and by anti-immigrant groups as calculating to strategically give birth within the country's borders. Thus, they face particular forms of discrimination which are directly related to their reproduction and the perceived threat that this involves (see also Chavez 2004). However, citizenship has a role in the debates on illegal women in Germany as well, since it currently has one of the lowest birth rates among wealthy nations. In 2005, the number of births reached an all-time post-war low, and the total population has been shrinking for several years in a row. Population movements - both by foreigners coming into the country and by Germans fleeing poorer regions - have resulted in what has been called 'demographic theft', in which there is a continuing decline in the native birth rate coupled with a simultaneous increase in the birth rate among foreign-born populations, so that these are expected one day to displace the native population (The Economist 2006). With an average of I.3 children per woman of child-bearing age, the current birth rate is much lower than the 2.I rate demographers suggest is needed in order to replace the population. Nonetheless, there remains a contradictory stance towards pregnancy based on race and ideas of national belonging. Citizenship is not available to the children of most migrants born in Germany. This means that, unlike in the US, pregnant illegal women are generally not viewed as strategically giving birth in the host country in order to obtain citizenship rights for their children and, by extension, residency rights for the mother. However, they are more likely to be vilified for trying to gain access to the nation's sophisticated social welfare system, despite strong evidence against their alleged use of such services (Van der Leun 2003).

\subsection{Access to medical treatment: Policy situation}

Romero-Ortuño (2004) has examined health care for illegal migrants in the European Union and inquires whether adequate solutions do ex- 
ist. He compares six countries with two types of health care systems: the social health insurance systems of Germany, Belgium and the Netherlands, and the tax-financed national health services of the United Kingdom, Spain, and Italy. Only Spain, he concludes, has created the legal conditions for the comprehensive health care coverage of illegal persons. This is followed by the 'generosity' system put into place in Italy, another tax-financed system, where migrants can remain anonymous while accessing medical care. These 'humanitarian' models contrast sharply with the 'utilitarian' approach of Germany (and to a lesser extent, the UK), where only emergency treatment is provided and only then because it is justified by a desire to protect the health of the host population.

In fact, Germany is often characterised as having the most restrictive laws governing health care for illegal migrants. In practice, however, access to care is limited by many other factors beyond these legal preconditions. Particularly in social health insurance systems, providers may be reluctant to treat patients who are unable to pay. Another issue that begs analysis is how restricting access for illegal migrants can be reconciled with the commitment to universal health care. While migrants with legal residency status enjoy the same health insurance coverage as German nationals, illegal migrants are left without any apparent rights. Their presence has resulted in a tension between traditional notions of universal health care for those paying into the social welfare system and humanitarian concerns of providing at least basic medical services for all persons, legal or not. Overall, the situation for illegal migrants in Germany is one in which certain minimal rights are technically available. However, based on my own research findings, migrants are not necessarily assured access to these rights.

Confounding the situation in Germany is a unique set of laws which criminalises not only migrants, but also health care professionals who offer them assistance. The Residence Act (Aufenthaltsgesetz) contains two specific sections that in essence criminalise the provision of medical care to illegal migrants. A section of the Act, often called the 'Denunciation Law', mandates that persons residing in Germany illegally be reported to the appropriate authorities if they seek services at public facilities. Because of their illegal residency status (though not necessarily because they have sought out medical treatment), this may initiate the deportation process. Similarly, if a private physician or hospital administrator seeks reimbursement for the costs of treating an illegal person, they can send the bill to the Social Welfare Office, which in turn is required to report the migrant to the Foreigners' Office. A second law, often referred to as the 'Trafficking Law', states that 'assisting' illegal persons - including for medical purposes, depending on interpretation - is a crime punishable with a fine or imprisonment up to five 
years. Doctors can be held liable if they treat illegal patients. It should be noted that, to my knowledge, no health care workers have been pursued under these laws, though some have been threatened with prosecution (see Castañeda 2007). However, there have been cases where patients have been deported because they have been reported by hospital staff. Either way, fear, uncertainty and ambiguity work to reinforce the current situation. Despite heavy opposition by medical and human rights communities, both laws remain in effect in the Act's 2005 revision.

By contrast, even though the US possesses a fraction of the social welfare services provided in many European nations, its situation can perhaps be assessed as better for illegal migrants. Since there are so many Americans and legal residents who are uninsured (or under-insured), the system can often accommodate illegal immigrants more easily, or at least with less visibility. In fact, the US health care system is predicated on notions of categorisation and exclusion, making it strikingly different from the German situation. At the same time, Americans are proud of their generosity. This creates a paradoxical setting in which 'the impulses of exclusion and charity together drive the engine of American health care' (Hoffman 2006). The fact that these are viewed as necessary features of the same system reflects a society accustomed to inequities.

As in Germany, a number of civil society organisations offer services to illegal migrants. Migrants have access to emergency Medicaid services, which reimburse hospitals for emergency care of the poor, regardless of legal status. However, since there are no provisions for other forms of care, emergency rooms are overburdened as the only 'safety net' for these and other uninsured persons. Beyond emergency services, the availability of care for immigrants (legal or illegal) varies from state to state. While over too migrant health centres are scattered around the nation, they are under-utilised and designed to serve primarily migrant farm workers. Over the past decade, the legal climate has become increasingly hostile, and several proposals for restricting and even criminalising medical assistance have appeared. In 2005 alone, some 80 bills in twenty states were proposed in order to cut non-citizens' access to health and other social services, or to require that the authorities be notified when an illegal person seeks out medical care. Much of the recently proposed legislation is aimed specifically at pregnant women and the services they require. 


\subsection{Pregnant and illegal}

In this section, I provide some perspective on women's experiences in both settings, touching upon several themes. Firstly, I will discuss the perils associated with entering illegally as a pregnant woman (a major concern along the US-Mexico border) versus becoming pregnant as an illegal resident and seeking out medical care (a greater concern for women in Germany). Next, I will note that migrants and their newborns are protected from deportation in both settings, but based on very different grounds.

\subsubsection{Gendered border crossings}

In the US, public debates around pregnancy and migration have centred on the concept of anchor babies. This derogatory term refers to children born on US soil who cement their illegal mother's - and potentially other family members' - permanent residency status. In recent years, the media has thrived on stories of dramatic rescues in the desert and babies being delivered by Border Patrol officers, which, by extension, has promoted blame and discrimination towards mothers who would risk such a journey. There is no doubt that the journey is a dangerous one: since I994 there have been over 3,000 border deaths, with the majority occurring in the state of Arizona (compare this, for instance, with the 239 deaths in the 28 -year history of the Berlin Wall) The majority of fatalities are the result of accidents or dehydration in the severe desert climate.

7 August 2006. Teresa Chavez, 2I, of Zamora, Mexico was seven months pregnant when she was injured in the crash of a smuggling vehicle carrying 2I undocumented migrants near Yuma, Arizona. The vehicle was fleeing Border Patrol agents at a very high speed and rolled over as a result of the driver's risky manoeuvring. Eleven migrants were killed, including the unborn baby of another I7 year old woman. An additional twelve persons were injured, including Teresa's husband, now in a coma. She gave birth days after the accident via caesarean section in a Phoenix hospital. The baby girl, named 'Milagros' ('Miracles'), weighed 3 pounds, II ounces. (Washington Post 2006, Arizona Daily Star 2006)

For women, who estimates suggest constitute up to one-third of all entrants, crossing the border presents particular dangers. Rape is a distinct possibility of which many are aware, and some women report taking birth control pills immediately before, during, and after their tra- 
vels for this reason. Others align themselves with male relatives or friends. Veronica, ${ }^{3}$ a woman I met in Sasabe, Mexico - just miles from the US border - was waiting to cross with a group of about twenty others. She introduced me to her boyfriend, whom she met on the trip north from the Yucatan, confiding that 'it's better to have a boyfriend to travel with, it keeps you safe'. While it is not known how many women cross while pregnant, there are most certainly a wide range of circumstances, ranging from calculated decisions to deliver in the US and a lack of knowledge of how delivery location affects citizenship and legal status to women who actually become pregnant as a result of the journey.

\subsubsection{Pregnant and seeking medical care}

Another scenario plays out when women already in the host country face exclusion from health care services. For this, we can turn to an example from Germany.

Sarah, a 33-year-old woman from Ghana, had been living in Germany for over a year when she became pregnant. She had arrived with next to nothing (just 'two pairs of trousers') because she was not planning on staying, but then decided to stay and find work. When her tourist visa expired, she became illegal. While in Germany, she met a man, Joaquim, at a party. After a few months of dating, she discovered she was pregnant - something she had not planned. 'Of course not,' she told me, 'this is not the right time, when you're in Europe, all alone with no papers!'

Pregnancy introduces additional costs for illegal parents, unlike their legal counterparts. These costs are based on their need to remain inconspicuous and on the types of work they may perform. Children require extra resources, including out-of-pocket costs for delivery and medical care. Parenthood may result in loss of work time and lack of mobility, especially important for the types of 'flexible' labour sectors in which many illegal migrants are employed. Also, pregnancy increases the mother's visibility - and subsequent deportability - because of the need to interact with the public health care system and state offices in order to apply for a birth certificate. While pregnancy terminations are reportedly common for legal immigrant women as well, they are an especially attractive option among illegal women for the reasons outlined above, namely their more vulnerable forms of employment and desire to reduce visibility. 
A friend at an African organisation told Sarah to go to the Centre for Family Planning, which offered prenatal care for many illegal women in Berlin. They provided regular prenatal examinations for a nominal fee. She was also sent to the Migrant Clinic (which worked closely with the Centre for Family Planning) for all of her blood tests and to arrange a low-cost delivery spot at a local charity hospital.

The physicians I interviewed noted that all pregnancies among illegal migrant women must be considered high-risk, due to socioeconomic marginalisation and delays in seeking prenatal care. This is certainly in line with the available literature (Bollini 2000; Gross 2005; Scott 2004; Willen 2005). In particular, epidemiological studies suggest a high rate of miscarriage, premature birth and high infant mortality among women with uncertain legal status. Delay is certainly a risk factor, since most women do not seek medical care until the third trimester. Because medical aid to this population is criminalised under German law, prenatal care is infrequent and women may fear entering public hospitals. Nonetheless, women and their newborns can generally find organisations or individual physicians willing to provide care, especially in urban areas. These types of informal local arrangements have been observed in a number of settings (see also Verbruggen 200I; PICUM 2002; Van der Leun 2003). These organisations will assist the mother or parents by arranging a delivery spot at a 'trusted' hospital where deportation is less likely. Neither prenatal care nor delivery is easy to finance for illegal migrants unless the father is German and has acknowledged paternity before the child is born. In these cases, reimbursement can occur through the social welfare system or via the father's insurance, although it may be retroactive and dependent upon submission of a birth certificate (see more on paternity below). Women from neighbouring countries sometimes travel home in order to give birth, and European Union citizens (e.g. from Poland) can often arrange some type of financial coverage if they opt to give birth in Germany. Other women do not have these options and simply go to the hospital when birth is imminent and pose as a tourist. A final option is to utilise various forms of 'anonymous' hospital deliveries, sometimes requiring the parents to put the child up for adoption (Anderson 2003).

\subsubsection{Protection from deportation}

In both Germany and the US, illegal women and their newborns are protected from deportation, but based on very different lines of reasoning. Children born on US soil have a right to citizenship, and their im- 
mediate family members can gain legal residency based on their status as caretaker(s). While there are limitations to this principle, it is based on notions of state obligation towards its citizens - and by extension, family members who are constructed as also deserving protection. Debates over immigration reform and the popular protest they invoked throughout 2006 and 2007 have brought issues of family unity to the forefront. For instance, the widely publicised story of Mexican migrant Elvira Arellano and her eight-year-old son Saul, a US citizen, highlighted the situation of families of mixed legal status. Prior to her apprehension in August 2007, she had sought refuge in a Chicago church for a year in order to avoid separation from her son. She thus became a prominent figure in discussions on the rights of illegal migrants, emphasising the role of US-born citizen children in the discourse of deservingness and opportunities for their family members.

The situation in Germany is rooted in the social welfare construction of maternity protection, reflecting how gendered conceptualisations continue to influence the politics of deportation (see Reinecke, this volume, for an historical example of gendered deportation policy in Germany). The I968 Maternity Protection Act established a time period (called the Mutterschutz) six weeks before and eight weeks following birth. During this time, all women are accorded certain protections, such as maternity leave. For an illegal woman, this represents a crucial period during which she cannot be deported. In order to formally take advantage of the Mutterschutz, a pregnant woman must register at the local courthouse and then apply for a residency permit at the Foreigner's Office. She is then eligible for a Duldung (a 'temporary suspension of deportation', effectively a short-term legalisation), which also authorises access to prenatal care and covers delivery costs. If the woman does not register, her child is generally born into illegality and it may be difficult to obtain a birth certificate. Even without the registration and formal Duldung, pregnant women are entitled to the protection period. The formal paperwork entitles them to compensation for delivery costs, so many hospitals encourage women to complete this step. However, by availing themselves of this procedure, they draw the attention of the authorities, who might look for them once the Mutterschutz period has expired. In my interviews with both NGO workers and migrants, it became evident that many migrant women are too scared to complete this process. In addition, there have been situations where the Mutterschutz was not honoured by the immigration authorities. Staff from an NGO working with trafficked women told me of a recent case in which the police arrived at their safe-house looking for a Mongolian woman and her ten-day old child (i.e. both clearly still within the protection period), to arrest them for deportation. Fortunately, the staff were able to intervene in this particular situation. 
Fatherhood is established through a formal acknowledgement of paternity (Vaterschaftsanerkennung), which is ideally registered before the child is born. Completion prior to the birth makes the entire process less risky for all parties involved, since it also reinforces the protection of the mother from being deported. Some of the women I spoke with appeared to be aware of the process of paternity acknowledgement. This is likely to have resulted from a combination of experience, wordof-mouth and the aid of various organisations. However, not all the information that circulated was accurate or complete. Many of the women with whom I spoke were not aware of the law at all. Others assumed there was no relationship between bearing a child in Germany and any improvement in their illegal residency situation. Still others were astounded to learn that children were not automatically German citizens when born in Germany. Children are eligible for citizenship, though only if the father is German. This can also result in a residency permit for the mother and access to the social welfare system, justified by the child's status as a German national. Perhaps not surprisingly, a shadow business in paternity acknowledgements has emerged. As I discuss elsewhere (Castañeda 2007), there is some evidence of false paternity claims being made in exchange for money, although the extent of this practice is debatable. It is made possible by a loophole opened in a law of 1998 ( $\$ 1592$ Bürgerliches Gesetzbuch), whose aim was to expand the rights of single mothers. According to this section, the mother has the right to declare the identity of her child's father, which is then backed by the father's acknowledgement. As a result, no one and particularly not the state - has the right to request verification of the claim. Thus the law intentionally allows fatherhood to exist for a non-biological parent (the so-called 'social father' as opposed to the 'biological father').

Finally, the acquisition of the child's birth certificate entails contact with state officials, an anxious moment for many illegal parents. This document is of the utmost importance - without it, the child has no nationality and is considered to be illegal. The United Nations High Commissioner for Refugees has urged a resolution to this problem, stating that the registration of a child must occur regardless of legal status (UNHCR 2003); furthermore, under German law every birth must be registered without delay. In some municipalities the process is more difficult than in others. For example, during my study in Berlin, local agencies implemented a policy in which only a valid passport would be accepted as the mothers' identification. Women whose passports were expired, lost or confiscated (which often happens in the case of human trafficking) were issued generic birth certificates for their children which did not name them as the legal parent. This can have grave implications if mother and child become separated, for example 
during detention, and there have been cases where the separation of a mother and her child did occur (Braun, Brzank \& Würflinger 2003).

The examples provided here have highlighted illegal women's vulnerability and lack of rights in their host countries. However, it is important not to lose sight of their agency as they negotiate through this process, lest they be cast only and always as victims. In both settings, pregnant women actively sought out various resources, from social support provided by compatriots to medical care provided by NGOs, private physicians, health departments and emergency rooms. Women made vital decisions along the way: to migrate - even under extreme circumstances - in order to provide a better life for their families rather than remain in poverty; to keep or terminate a pregnancy; to ask for help, despite their deportability; to stay away from options that might have afforded them adequate prenatal care for fear of being detected and subsequently deported; to discover and draw upon various legal loopholes; to pay high sums for private-pay deliveries rather than approach state offices; and to apply or not to apply for formal protection from deportation.

\subsection{Conclusion}

In debates on illegal immigration, one of the most contested issues is whether social services should be offered to residents who do not formally participate in the system. I have focused here on migrant women because the restricted access to medical services sheds light on the contradictions between the general marginalisation of illegal migrants and ideas of moral obligation towards pregnant women and their children. In both nations, illegal pregnant women and their children are deemed to be particularly deserving of assistance while simultaneously being viewed with suspicion, so that states are caught in the 'contradictory impulses of sympathy and exclusion' (Hoffman 2006). Because they may bear children in the host country, illegal migrant women are confronted with different forms of discrimination as well as with potentially different resources. Since the end of the nineteenth century, states have become involved in administering systems of welfare and are increasingly discerning as to how these services are allocated. Today, states with more costly and elaborate social welfare systems often have a greater interest in controlling migration than those with a lower level of welfare resources. This move towards ever greater discriminative features, facilitated through paradoxical and contradictory legal guidelines, represents changing state practices evident in the case study offered here. Germany has a sophisticated and tightly controlled health care system, and it restricts the access of illegal residents to it. 
While premised in a commitment to universal entitlement, it effectively excludes illegal migrants through a series of vague policies, criminalising the provision of care. Becoming pregnant as an illegal resident is of greater concern for women in Germany than in the US since they must seek out medical care and thereby face a relatively high risk of exposure and deportability. In the US, by contrast, the labour market relies heavily on millions of illegal migrants, yet there is a comparatively poor system of social services, which has resulted in a comparatively less restrictive internal policy climate. Illegal migrants are often able to find medical aid in the same manner as other uninsured and under-insured individuals: that is, through overburdened emergency rooms and by relying on charity services. However, the implications of the US citizenship model have resulted in a much more elaborate national border control policy. As a result of more restrictive and militarised borders, migrant women coming to the US often face higher risks during entry and are portrayed as a threat to national identity. Finally, migrant women's chances of remaining illegal can differ from those of the men. In both Germany and the US, women can legalise their stay in ways that men cannot - either by giving birth in the host country (in the US) or by having a child whose father is a national or long-term legal resident (in Germany). Even in countries with very different social welfare systems and notions of national belonging, migrant illegality remains a highly gendered construction with different implications for men and women.

\section{Notes}

I $\int 87$ of the Residence Act is often referred to as the Denunziationsparagraf.

$2 \sqrt{ } 9^{6}$ of the Residence Act is often referred to as the Schlepperparagraf.

3 All participant and organisation names used herein are pseudonyms.

\section{References}

Anderson, P. (2003), 'Dass Sie uns nicht vergessen...': Menschen in der Illegalität in München. Munich: Landeshauptstadt München Sozialreferat.

Arizona Daily Star (2006), 'Kin of injured migrants blame agents for rollover', 26 August 2006.

Bollini, P. (2000), 'The health of migrant women in Europe: Perspectives for the year 2000', in M. David, T. Borde, \& H. Kentenich (eds.), Migration, Frauen, Gesundheit: Perspektiven im europäischen Kontext, I97-206. Frankfurt am Main: Mabuse Verlag.

Braun, T., P. Brzank, \& W. Würflinger (2003), 'Medizinische Versorgung von illegalisierten Migrantinnen und Migranten: Ein europäischer Vergleich', in T. Borde \& M. David (eds.), Gut versorgt? Migrantinnen und Migranten im Gesundheits- und Sozialwesen. Frankfurt am Main: Mabuse Verlag. 
Castañeda, H. (2007), Paradoxes of providing aid: NGOs, medicine, and undocumented migration in Berlin, Germany. PhD thesis. Department of Anthropology. Tucson: University of Arizona.

Chavez, L. R. (200I), Covering immigration: Popular images and the politics of the nation. Berkeley: University of California.

Chavez, L. R. (2004), 'A glass half empty: Latina reproduction and public discourse', Human Organization 63(2): I73-I89.

Cyrus, N. (2004), Aufenthaltsrechtliche Illegalität in Deutschland: Sozialstrukturbildung Wechselwirkungen - Politische Optionen. Nuremberg: Sachverständigenrat Zuwanderung und Integration.

De Genova, N. P. (2002), 'Migrant "illegality” and deportability in everyday life', Annual Reviews of Anthropology 3I: 4I9-447.

Economist, The (2006), 'Cradle snatching', The Economist I8 March 2006, 378(8469): 55.

Fassin, D. (2005), 'Compassion and repression: the moral economy of immigrant policies in France', Cultural Anthropology 2O(3): 362-387.

Gross, J. (2005), Möglichkeiten und Grenzen der medizinischen Versorgung von Patienten und Patientinnen ohne legalen Aufenthaltsstatus. Berlin: Flüchtlingsrat Berlin e.V.; Büro für medizinsche Flüchtlingshilfe Berlin; PRO ASYL; IPPNW Deutschland.

Hoffman, B. (2006), 'Sympathy and exclusion: Access to health care for undocumented immigrants in the United States', in K. Wailoo, J. Livingston, \& P. Guarnaccia (eds.), A death retold: Jesica Santillan, The bungled transplant, and paradoxes of medical citizenship. Chapel Hill: University of North Carolina Press.

Lucassen, L., D. Feldman, \& J. Oltmer (eds.) (2006), Paths of integration: Migrants in Western Europe (1880-2004). Amsterdam: Amsterdam University Press.

Pew Hispanic Center (2006), Size and characteristics of the unauthorized migrant population in the U.S., Vol. 2006. Washington, D.C.: Pew Hispanic Center.

PICUM (Platform for International Cooperation on Undocumented Migrants) (ed.) (2002), Book of solidarity - volume 1: Providing assistance to undocumented migrants in Belgium, Germany, the Netherlands, and the UK. Antwerp: De Wrikker.

Romero-Otuño, R. (2004), 'Access to health care for illegal immigrants in the EU: Should we be concerned?’, European Journal of Health Law Iп: 245-272.

Sargent, C. F. (2006), 'Lamenting the "winter" of French fertility: Politics, power, and reproduction among Malian Migrants in Paris', Curare 29: 7I-80.

Scott, P. (2004), 'Undocumented migrants in Germany and Britain: The human "rights" and "wrongs" regarding access to health care', Electronic Journal of Sociology. http:// www.sociology.org.

Stobbe, H. (2004), Undokumentierte Migration in Deutschland und den Vereinigten Staaten: Interne Migrationskontrollen und die Handlungsspielräume von Sans Papiers. PhD thesis. Göttingen: Universitätsverlag Göttingen.

Tormey, A. (2007), “Everyone with eyes can see the problem”: Moral citizens and the space of Irish nationhood', International Migration 45(3): 69-100.

UNHCR (United Nations High Commissioner for Refugees) (2003), Verpflichtung zur Registrierung von neugeborenen Kindern Asylsuchender und Flüchtlinge. Berlin: United Nations High Commissioner for Refugees.

United Nations Population Fund (2006), A passage to hope: Women and international migration. UNFPA, the United Nations Population Fund.

Van der Leun, J. (2003), Looking for loopholes: Processes of incorporation of illegal immigrants in the Netherlands. Amsterdam: Amsterdam University Press.

Verbruggen, N. (ed.) (200I), Health care for undocumented migrants: Germany, Belgium, the Netherlands, United Kingdom. Antwerp: PICUM: Platform for International Cooperation on Undocumented Migrants. 
Washington Post (2006), '9 Die in Ariz. crash as SUV flees border patrol; at least I2 others hurt as vehicle rolls over in area known for immigrant smuggling', 8 August 2006.

Willen, S. S. (2005) 'Birthing "invisible" children: State power, NGO activism, and reproductive health among "illegal" migrant workers in Tel Aviv, Israel', Journal of Middle East Women's Studies I(2): 55-88. 


\section{About the authors}

Marlou Schrover is an associate professor of history at Leiden University. Her publications have dealt with women workers and technological change, labour relations, immigrant entrepreneurship, German migration and ethnic niche formation. She is currently leading a large research project on gender and migration. Together with Herman Obdeijn, she wrote Komen en Gaan. Immigratie en Emigratie in Nederland vanaf 1550, published by Bert Bakker in 2008.

Joanne van der Leun is a professor of criminology at Leiden University, where she teaches in the law faculty and coordinates the Bachelor's programme in criminology. Her research interests are legal and illegal migration and crime in the urban context and policies in practice. She is the author of Looking for Loopholes: Processes of Incorporation of Illegal Immigrants in the Netherlands, published by Amsterdam University Press in 2003.

Leo Lucassen holds the chair of social history at Leiden University. He is the author of The Immigrant Threat: The Integration of Old and New Migrants in Western Europe since 1850, published by the University of Illinois Press in 2005, and is a co-editor of Paths of Integration: Migrants in Western Europe (1880-2004), published by Amsterdam University Press in 2006.

Chris Quispel is an assistant professor of social history at Leiden University. His work is largely on the history of racism, ethnicity and migration, with a specialisation in the relationship between blacks and whites in the Unites States. He has published several books and many articles in both English and Dutch. His new field of interest is the direct social and economic consequences of border changes.

Corrie van Eijl is a researcher in the history department at Leiden University. She has published pieces on women's work and migration history. Her book Al Te Goed is Buurman's Gek: Het Nederlandse Vreemdelingenbeleid 1840-1940, published by Aksant in 2005, looks at a century of Dutch immigration policy.

Christiane Reinecke is a research fellow at the Humboldt University of Berlin. She received a Master's in modern history at University College London in 200I and a Master's in modern and contemporary history at 
the Humboldt University of Berlin in 2003. She wrote her Master's thesis at the Berlin School for Comparative European History on the politics of immigration control in Britain and Germany between I880 and 1930.

Ilse van Liempt currently holds a position as a Marie Curie Research Fellow at the Sussex Center for Migration Research at the University of Sussex. She received her PhD at the Institute for Migration and Ethnic Studies of the University of Amsterdam, and her dissertation Navigating Borders: Inside Perspectives on the Process of Human Smuggling into the Netherlands was published by Amsterdam University Press in 2007. Her main research interests are irregular migration, human smuggling, human trafficking, asylum and gender.

Blanca Garcés-Mascareñas is currently working on her PhD on the legal production of irregularity in Malaysia and Spain at the Institute for Migration and Ethnic Studies of the University of Amsterdam. In 2005, she worked at the same institute as a junior researcher to study trafficking and forced labour among West African migrants in the Netherlands. In 2004 she obtained a Master's in ethnic and migration studies at the International School for Humanities and Social Sciences at the University of Amsterdam. She graduated from the University of Barcelona in 1999 with a degree in history and in 2000 with a degree in anthropology. Her publications have dealt with immigration and integration policymaking in the Netherlands.

Ali Nobil Ahmad is a London-based researcher and freelance journalist. He received his PhD in history and civilisation from the European University Institute in Florence, and has worked as a research officer at the University College London on the Leverhulme Programme on Migration and Citizenship. His publications have dealt with human smuggling, illegal work, gender and sexuality. His regular contributions on art and cultural politics appear in the media and periodicals such as Third Text, Untold London, Metamute, Wasifiri and Dark Matter.

Annelies Moors is professor of anthropology at the University of Amsterdam and director of the Muslim Cultural Politics research programme at the International Institute for the Study of Islam in the Modern World. She is the author of Women, Property and Islam: Palestinian Experiences 1920-1990, published by Cambridge University Press in 1995, and was a partner in the SSRC International Collaborative Research Project called 'Migrant domestic workers: A new public presence in the Middle East'. Her publications have dealt with debating 
family law, visualising the nation-gender nexus, gold and globalisation, Muslim fashions and migrant domestic labour in the Middle East.

Marina de Regt is an anthropologist working at the International Institute of Social History in Amsterdam. She received her PhD from the University of Amsterdam in 2003, and her dissertation on women health workers in Yemen was published by Syracuse University Press in 2007. From 2003 to 2006, she conducted post-doctoral research on migrant domestic workers in Yemen, and her present research interests are gender, labour, migration and development in the Middle East.

Heide Castañeda is assistant professor of anthropology at the University of South Florida. Her primary research interests include illegal migration, health inequalities, human rights and humanitarianism and the politics of citizenship. Her work has appeared in Medical Anthropology and Health Promotion Practice, and she contributed to Transnational Migration to Israel in Global Comparative Context, published by Lexington Books in 2007. 



\section{Other IMISCOE titles}

\section{IMISCOE Research}

Rinus Penninx, Maria Berger, Karen Kraal, Eds.

The Dynamics of International Migration and Settlement in Europe:

A State of the Art 2006 (ISBN 9789053568668 )

(originally appearing in IMISCOE Joint Studies)

Leo Lucassen, David Feldman, Jochen Oltmer, Eds.

Paths of Integration: Migrants in Western Europe (1880-2004)

2006 (ISBN 9789053568835 )

Rainer Bauböck, Eva Ersbøll, Kees Groenendijk, Harald Waldrauch, Eds. Acquisition and Loss of Nationality: Policies and Trends in 15 European Countries, Volume 1: Comparative Analyses

2006 (ISBN 978905356920 7)

Rainer Bauböck, Eva Ersbøll, Kees Groenendijk, Harald Waldrauch, Eds. Acquisition and Loss of Nationality: Policies and Trends in 15 European Countries, Volume 2: Country Analyses 2006 (ISBN 978905356 921 4)

Rainer Bauböck, Bernhard Perchinig, Wiebke Sievers, Eds.

Citizenship Policies in the New Europe 2007 (ISBN 978905356922 I)

Veit Bader

Secularism or Democracy? Associational Governance of Religious Diversity 2007 (ISBN 9789053569993 )

Holger Kolb \& Henrik Egbert, Eds.

Migrants and Markets: Perspectives from Economics and the Other Social Sciences

2008 (ISBN 9789053566848 )

Ralph Grillo, Ed.

The Family in Question: Immigrant and Ethnic Minorities in Multicultural Europe 2008 (ISBN 9789053568699 ) 
Corrado Bonifazi, Marek Okólski, Jeannette Schoorl, Patrick Simon, Eds. International Migration in Europe: New Trends and New Methods of Analysis 2008 (ISBN 978905356894 I)

Maurice Crul, Liesbeth Heering, Eds.

The Position of the Turkish and Moroccan Second Generation in Amsterdam and Rotterdam: The TIES study in The Netherlands 2008 (ISBN 978908964 06I I)

\section{IMISCOE Reports}

Rainer Bauböck, Ed.

Migration and Citizenship: Legal Status, Rights and Political Participation 2006 (ISBN 978905356888 o)

Michael Jandl, Ed.

Innovative Concepts for Alternative Migration Policies:

Ten Innovative Approaches to the Challenges of Migration in the 21st Century 2007 (ISBN 978905356990 0)

Jeroen Doomernik \& Michael Jandl, Eds.

Modes of Migration Regulation and Control in Europe 2008 (ISBN 978905356689 3)

\section{IMISCOE Dissertations}

Panos Arion Hatziprokopiou

Globalisation, Migration and Socio-Economic Change in Contemporary Greece: Processes of Social Incorporation of Balkan Immigrants in Thessaloniki

2006 (ISBN 9789053568736 )

Floris Vermeulen

The Immigrant Organising Process: Turkish Organisations in Amsterdam and Berlin and Surinamese Organisations in Amsterdam, 1960-2000 2006 (ISBN 978905356875 o)

Anastasia Christou

Narratives of Place, Culture and Identity: Second-Generation

Greek-Americans Return 'Home'

2006 (ISBN 978905356878 I) 
Katja Rušinović

Dynamic Entrepreneurship: First and Second-Generation Immigrant Entrepreneurs in Dutch Cities

2006 (ISBN 9789053569726 )

Ilse van Liempt

Navigating Borders: Inside Perspectives on the Process of Human Smuggling into the Netherlands

2007 (ISBN 9789053569306 )

Myriam Cherti

Paradoxes of Social Capital: A Multi-Generational Study of Moroccans in London

2008 (ISBN 9789053560327 )

Marc Helbling

Practising Citizenship and Heterogeneous Nationhood: Naturalisations in Swiss Municipalities

2008 (ISBN 978908964034 5) 